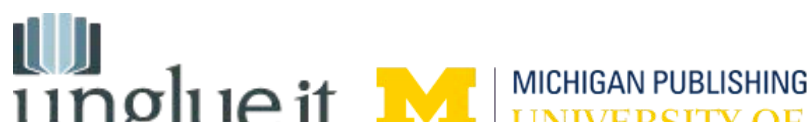

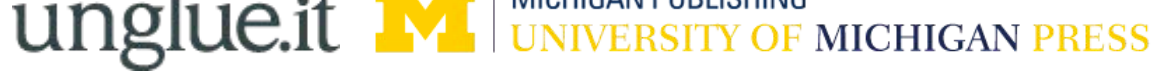

\section{ONLINE SURVEY}

In collaboration with Unglue.it, we have set up a survey (only ten questions!) to learn more about how open access ebooks are discovered and used.

We really value your participation-please take part!

\section{CLICK HERE}

An electronic version of this book is freely available, thanks to the support of libraries working with Knowledge Unlatched. $\mathrm{KU}$ is a collaborative initiative designed to make high quality books Open Access for the public good. 

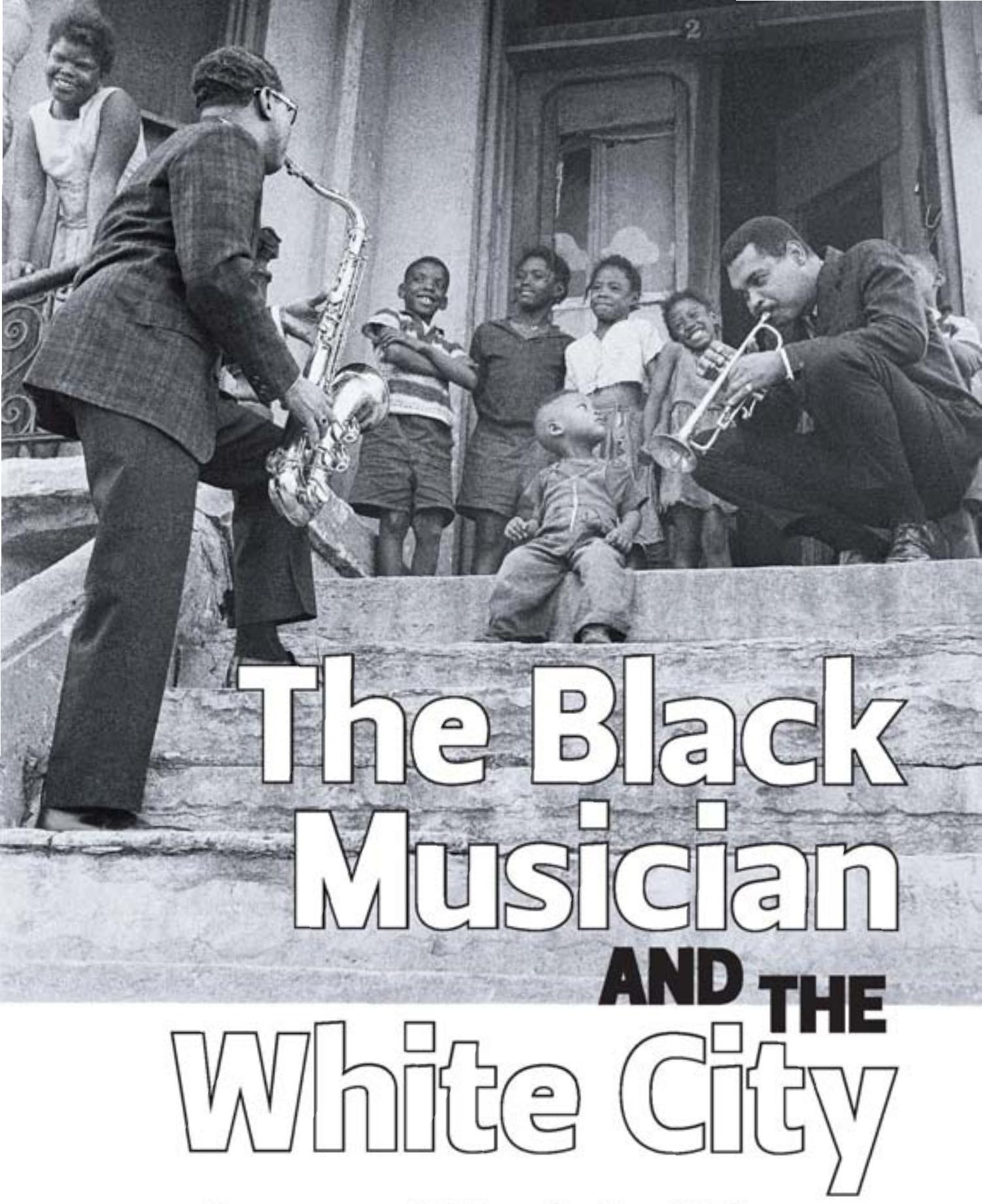

Race and Music in Chicago,

1900-1967

AMY ABSHER 
The Black Musician and the White City 



\title{
The Black Musician and the White City
}

RACE AND MUSIC IN CHICAGO, I900-I967

\author{
Amy Absher
}


Copyright (C) by the University of Michigan 2014

All rights reserved

This book may not be reproduced, in whole or in part, including illustrations, in any form (beyond that copying permitted by Sections 107 and I08 of the U.S. Copyright Law and except by reviewers for the public press), without written permission from the publisher.

Published in the United States of America by

The University of Michigan Press

Manufactured in the United States of America

@ Printed on acid-free paper

$\begin{array}{llllllll}20 I 7 & 20 I 6 & 20 I 5 & 20 I 4 & 4 & 3 & 2 & \text { I }\end{array}$

A CIP catalog record for this book is available from the British Library.

Library of Congress Cataloging-in-Publication Data

Absher, Amy. The black musician and the white city : race and music in Chicago, I900-I967 / Amy Absher.

pages $\quad \mathrm{cm}$

Includes bibliographical references and index.

ISBN 978-0-472-I I 9I7-2 (cloth : alk. paper) — ISBN 978-0-472-02998-3 (e-book)

I. African Americans-Illinois-Chicago-Music_History and criticism.

2. Popular music-Illinois-Chicago-History and criticism. 3. Popular music-Social aspects-Illinois-Chicago-History-2oth century. 4. Music and race-Illinois-Chicago-History-2oth century. 5. African American musicians-Illinois-Chicago. 6. Music trade-Illinois-Chicago-History2oth century. 7. African American musicians-Labor unions-IllinoisChicago-History-2oth century. 8. Musicians-Labor unions-IllinoisChicago-History-2oth century. I. Title.

ML3479.A26 20I4

$780.89^{\prime} 960730773$ I I-de23 
To Charles Walton and Edward O. Bland 



\section{Contents}

Acknowledgments ix

Introduction $\quad$ I

CHAPter i: Musicians and the Segregated City:

Chicago in the Early I900s-I930s I6

CHAPTER 2: From South to South Side:

Musicians in I940s Chicago 48

CHAPter 3: Redefining the Music Industry:

Independent Music in Chicago, I948-I953 82

CHAPter 4: From South Side to the South and

the Nation, I954-I963 98

CHAPTER 5: Dissonance and the Desegregation of Chicago's

Musicians' Union, I963-I967 I I9

$\begin{array}{ll}\text { Coda } & \text { I47 }\end{array}$

$\begin{array}{ll}\text { Notes } & 149\end{array}$

$\begin{array}{ll}\text { Bibliography } & \text { I87 }\end{array}$

$\begin{array}{ll}\text { Index } & 199\end{array}$ 



\section{Acknowledgments}

his project would have been impossible without the finan-
cial support of the history department at the University of Washington and the SAGES program at Case Western Reserve University. I wish to express my sincere appreciation to my graduate advisor, Professor John Findlay, who made all things achievable. I would also like to thank my committee members-Professors Quintard Taylor, Marc Seales, and the extraordinary Carol Thomas-for their friendship, guidance, patience, and support.

I owe a great debt to librarians, archivists, artists, preservationists, and researchers who shared their expertise and opinions and showed me how to realize this project. They include the essential Theresa Mudrock and the indomitable Suzanne Flandreau as well as Andy Leach, Janet Harper, Joe Bartl, Dale Mertes, Morris A. Phibbs, Horace Maxile Jr., Richard Schwegel, Frank Latino, Melanie Zeck, Jennifer Phelps, and the staff of the Harold Washington Library's music collection. They represent an essential academic resource to all scholars that is now being underfunded by shortsighted university and institutional planners looking to make up budget shortfalls. Without properly funded and staffed libraries and archives, studies such as this one might not be possible in the future.

In addition, I am grateful to Professor James Grossman, Professor Leon Fink, The Dr. William M. Scholl Center for American History and Culture at the Newberry Library, the Center for Black Music Research, the Archdiocese of Chicago, and International House at the University of Chicago for providing me with access to a community of scholars in Chicago. Particularly, I would like to single out my colleagues from the Newberry Library's Urban History Dissertation Group: Tamsen Anderson, Phyllis Santacore, Marygrace Tyrrell, David Spatz, Ed Miller, Jennifer 
Vanore, and Jessica Westphal. Their assistance raised the level of scholarship in this project.

My life in Chicago was eased greatly by the assistance of my friends at I-House. In this regard, I owe special thanks to Maria Accosta, Norberto Lopéz, Martha Sosa, Jeanette Doss, Burt Doss, Undre Moore, Dolores, Deborah Jones, and Wally Thomas.

I feel privileged to have been mentored by Edward O. Bland and Tom Crown. Professors Scott Casper, David Ake, Eric Porter, Margaret Urie, Mehdi Etezadi-Amoli, Richard Johnson, William Rorabaugh, and Jon Bridgman will no doubt see their influence on this work. I hope they will be proud. Furthermore, I count myself fortunate to have had the support of the faculty and staff in Case Western Reserve University's SAGES program: above all, my boss Peter Whiting, John Orlock, Janet Alder, Sharmon Sollitto, and Carrie Kurutz. Arthur Evenchik deserves special thanks for bringing me to Case and for assisting me in editing this book. Likewise, I am grateful to my friends at the Dittrick Medical History Center, Jim Edmonson and Jennifer Nieves, who have given me their friendship and an intellectual home in Cleveland. I am also thankful for the friendship and support I have found in Case's history department-especially Professors Jonathan Sadowsky, Alan Rocke, John Broich, Ken Ledford, Jay Geller, and Wendy Fu. In addition, I am lucky to have had the support of my students. At Case, Samuel Esterman and Selvaanish Selvam became essential to the completion of this book. At UW, Kelley Mao, Erin Andersen, Zach Takasawa, and Sarah Goethals all wrote me letters and cards to encourage me while I was working on my dissertation in Chicago.

As with all books, the project would have been impossible had it not been championed by a book editor. Chris Hebert saw potential in the work when all it was an abstract. Marcia LaBrenz was the project manager who saw the publication process through to completion. I wish to thank them, along with the press's staff, for their guidance and hard work, and for their ability to imagine the end results.

Then there were the friends. Mariana Gatzeva, Keiko Kirby, Vincent Howard, Emmie Vance, Justyna Stypińska, Roey Moran, Tim Blake, Guatam, Janel Fontana, Dave Bryant, Henry Ramirez Le Maire, Rosina Mora, Liz Johnson, Brian Casserly, Brian Schefke, Tristan Goldman, Chris Herbert, Scott Brown, Sasho, Mary Geiger, Mitzi Melendez, Daniel Morales, Derek Botha, Qiyan Mao, Nori, Rob Walsh, Abby Adams, Bea, Jim 
Lea, John Mills, Jack Carver, Andrew Price Jr., Simeon Man, Stella Yee, Miriam Llorens Lopéz, Joe Frank, Shawn Tallant, Jill Koehler, Jeri Park, Jenn Weiss, Rachel Kapelle, Annie Cardwell, Elanda Goduni, Jon Hess, Elizabeth Doolittle, Mika Little, Joshua Sylvan, Ben Cook, Digby, Alex Shappie, Brittany Byrd, Conrad Moore, Steven Cramer, Jennifer Barclay, Michele Hanks, Michele Myers, Cheryl Glotfelty, Joan Sera, and Theresa Mudrock have my enduring gratitude.

Finally, I would like to thank my parents and my family. 



\section{Introduction}

$B_{\text {drew African American musicians by the thousands from }}^{y}$ throughout the American South. For many of them, Chicago was an obvious destination. After all, they knew it was a hub for the music industry, and they had purchased their recordings through the Sears, Roebuck and Co. catalog, which was published in Chicago. They received news of the city from the Pullman Porters, who spread Chicago's Black-owned newspapers throughout the South and in so doing helped to create an unbreakable link between the rural and the urban African American populations. In addition, Chicago was the home of professional organizations such as the National Association of Negro Musicians, classical-music training was available at the Chicago Conservatory and the University of Chicago, and there were high-quality Black-owned venues such as the Pekin Theater and the city's churches. ${ }^{1}$

All of this was seductive to African American musicians, but none of it changed the fact that Chicago was a "city of neighborhoods." This was a polite way of saying that it was a segregated city. The reality of Chicago's pigmentocracy was such that African American musicians were assured membership in the segregated American Federation of Musicians local, and that jobs in the city's symphonies, radio stations, and clubs outside of the "black belt" were largely off-limits. Therefore, migrating to Chicago meant that they would have to live in a segregated city. For many, living in the city required them to make choices regarding segregation. Some chose to dedicate themselves to undermining the racial system through performances, recordings, and professional organizations. Others sought to create an autonomous cultural sphere that could insulate musicians from the city's racism. 
The musicians were not afraid of facing segregation because segregation was a reality for them wherever they went. However, once in Chicago, they quickly came to understand that, although segregation was common in the United States, each place had a slightly different system. ${ }^{2}$ Therefore, they would have to adapt the responses they developed in the South and develop new techniques for negotiating and resisting segregation in the urban center. These techniques included playing outside the "black belt," uniting with European ethnics to challenge the music industry, organizing unions, participating in the city's higher-education facilities, and writing political compositions. Ultimately, many of the Black musicians emerged as activists responding to the limits placed on their ability to work throughout the city, to perform on the radio, and to record.

In the end, there was never just one form of segregation in Chicago, and there was never just one recourse against the oppression of segregation. Rather, the varied responses of the musicians illustrate that African Americans in Chicago held dynamic, and, at times, conflicting views. Daily, they had to make choices ranging from open resistance, to selfsufficiency, to negotiation. They had to modify their strategies as forms of segregation changed over time. Their choices suggest that African Americans, on the ground, were not stuck in the dualisms of W.E.B. Du Bois versus Booker T. Washington or the choice between Black activism fueled by an optimistic faith in democracy versus a pessimistic historical consciousness born of unbearable injustice. ${ }^{3}$ Instead, Black musicians needed diverse and complicated strategies for dealing with segregation because racism in Chicago was an outgrowth of the city's politics, which manifested itself at every level of life. ${ }^{4}$ In this way, the history of African American musicians is central to understanding the challenges to racial segregation in Chicago, and to demonstrating that the contest for control of the city between I900 and 1967 concerned not only physical and political territory but also cultural space.

At the same time, it is important to recognize that Chicago musicians were part of larger Black historical experiences such as urbanization, segregation, and the Black Freedom Movement. In addition, industrial restructuring, redevelopment and urban renewal, and the construction of highways shaped them just as these infrastructure changes shaped Black communities in other cities, as Robert Self argues in American Babylon and Derek Hyra explains in The New Urban Renewal: The Economic Transformation of Harlem and Bronzeville. They saw the failure, as described by Arnold Hirsch in Making the Second Ghetto and Alexander 
Polinkoff in Waiting for Gautreaux, of local, state, and federal officials to ensure civil liberties and economic opportunities. They also saw Black leaders acquiesce and compromise over these same issues. For these reasons many scholars, beginning with St. Clair Drake and Horace Cayton in Black Metropolis, contend that once one understands the history of African Americans in Chicago, one understands the history of African Americans in nearly every other city. ${ }^{5}$

It is easy to see why there are those who make a case for the essential nature of Chicago history to Black history. The city was an industrial giant that developed into the nation's production and distribution hub, which made it central to everything from economics to culture. The counterargument is that many other Black metropolises, such as Harlem or Detroit, could boast of the same thing. What Chicago had that the other cities lacked were the political and business leaders-including Ida B. Wells-Barnett, Oscar DePriest, John Johnson, Robert Abbott, and William Dawson-who inspired and built key Black institutions, such as the Urban League, the Chicago Defender newspaper, and Ebony and Jet magazines. By the I930s, Black Chicago's intellectual scene-with Richard Wright, Gwendolyn Brooks, Margaret Burroughs, and Archibald J. Motley Jr.- - had surpassed all contenders. ${ }^{6}$

Adding the musicians' participation in and perspective on historical events strengthens the argument for the importance of Chicago and its history. No other "Dark Ghetto," as Kenneth Clark would say, ${ }^{7}$ had a gospel scene as influential or well developed as that in Chicago. The city was also the home of all of the major music publishers, numerous conservatories that accepted Black musicians, ${ }^{8}$ and Mayo Williams-the artist and repertoire man for Paramount Records, the first major blues labelwho brought performers like Ma Rainey, Charley Patton, Blind Lemon Jefferson, Son House, and Alberta Hunter to Chicago. ${ }^{9}$ The revolution in music encouraged and strengthened the musicians' sense of racial pride and cultural achievements. They took their sense of dignity and importance born in the city to Black communities throughout the nation, in much the same way that the Pullman Porters and Black baseball players did. What distinguished the Black musicians from the other cultural ambassadors is that the musicians also influenced and changed, forever, white America. Therefore, the history of Black musicians in Chicago is more than a case study. The musicians' story is as inseparable from the national historical narrative as it is from the community-focused social history of the city. ${ }^{10}$ 
In exploring musicians' experiences and perspectives, I take an unconventional line: this book is not one type of history. Like Derek Vaillant's examination of the conjunction of musical progressivism and urban history in Sounds of Reform, I interweave several bodies of scholarship to create a historical framework that seeks to forge connections between the history of the musicians, the city, and the nation. The musicians' work lives mandate a labor history approach. Since a large part of their experience was as participants in the Great Migration, I knit together social history sources and methods with cultural history. I offer an examination of the sociopolitical history of the city as well as urban spaces-whether defined by notions of property, political wards, demographic lines, violence, or music. Also, there is the institutional history of the music business /Chicago venues, recording enterprises, radio and jukebox technologies, and touring activity). When appropriate, I bring in music theory and lyric analysis. The two things that tie these different approaches together are my concerns with change over time and with Black musicians' multiple responses to white supremacy.

In examining sources and constructing my arguments, I draw on Christopher Small's Music of a Common Tongue and Musicking. Small asserts that the act of making music "creates the public image of our most inwardly desired relationships, not just showing them to us as they might be but actually bringing them into existence. . ." In other words, making music structures the relationship between people and their understanding of space by articulating the rules that make certain relationships valid and others unsettling. Small understands music as a language or a grouping of symbols that makes rituals and myths visible. His ideas have guided me toward understanding music as an action and placing significance on studying the performance, the venue, the professional and amateur musicians, and the audience as manifestations of the role of music and musicians in society. ${ }^{11}$

Whereas Small provides an interpretive foundation for this project, Scott DeVeaux's The Birth of Bebop: A Social and Musical History offers a method. As DeVeaux points out, it is common to read histories of jazz, or blues, that treat the music as a living thing. But music is not a living thing. It has no motivations and makes no choices. It cannot plan a revolution, nor can it evolve. In short, music does not have agency. Rather than writing a history using metaphors, scholars would do better to look for the points where music and social movements collided. In that nexus are the musicians. DeVeaux argues that for musicians, social issues and 
music were not exclusive of one another; they were both important parts of musicians' lives. Therefore, a historical narrative should emphasize the musicians' choices. I diverge from DeVeaux in one major way. His work is concerned with the origins of a musical style and with understanding the relationships between the musician's stylistic choices and the larger musical developments. My work, in contrast, focuses on the musician as historical actor. ${ }^{12}$

Like other studies based on DeVeaux's method, such as Patrick Burke's "Come in and Hear the Truth": Jazz and s2nd Street, I seek to understand how musicians interpreted, negotiated, and resisted major historical moments during the mid-twentieth century with their music acting as a system of articulating their ideas. By emphasizing the network of musician relationships, as Burke does, it is possible to displace the mythology surrounding the musicians that has for decades obscured the scholar's understanding of the place of Black musicians in American history. For this reason, rather than focusing on the development of genres and instrumentation, in this book I examine the role of the musician in the history of migration, the musician experience in the segregated urban environment, and the building of a musician-led labor movement.

Certainly, there have been numerous studies of music in Chicago, such as Mike Rowe's Chicago Breakdown, Howland William Kenney's Chicago Iazz: A Cultural History I904-I930, and David Grazian's Blue Chicago: The Search for Authenticity in Urban Blues Clubs. While these books provide excellent music histories and focus on the musicians' perspective, beyond the Great Migration of African Americans to the city, they do not present the musicians as continually part of historical movements and of conflicts in the city. Nor do these books take into consideration the diversity in musical training and life experience among the musicians.

In addition, there is a noticeable gap in the historiography of African American musicians in Chicago. Whereas the I920s and post-I960s have been well examined by scholars, the I940s and I950s are less well understood. I am positioning my project historiographically between Kenney's Chicago Jazz and George Lewis's A Power Stronger Than Itself: The $A A C M$ and American Experimental Music. The strength of Kenney's work lies in his ability to tie musicians to the Great Migration and in his descriptions of the musician community. I carry the links Kenney pioneered forward by arguing that later migrants built on the strengths of the community developed in the early twentieth century. The significance 
of Lewis's work regarding the AACM (Association for the Advancement of Creative Musicians) is that he emphasizes the musicians' experiences with race in Chicago and how these experiences shaped the radicalism of the AACM. In my research, I examine musician-led organizing from the first years of the twentieth century through the I96os. In this way, my work examines the foundations of what became the AACM platform by demonstrating that musician radicalism was not born in the I96os and Black musicians did not have just one strategy for surviving and resisting racism in the city. In the end, my research provides the connections between the first waves of musicians to arrive in Chicago from the South and the development of various political perspectives among musicians in the I960s. Viewing the presence of musicians in Chicago's racial and cultural politics as a continuous and cumulative history makes it possible to understand how the musicians built a community, as well as what the results of their actions were.

A crucial part of understanding musicians as active historical figures is realizing that music is a result of musicians' discourse concerning aesthetic visions and cultural politics, not the inspiration for the discourse. Even if musicians were not recognized as intellectuals by the society at large, they functioned as intellectuals because they engaged in the work of challenging social orders, such as segregation in Chicago, creating social movements, and articulating the needs and motivations of the underclasses. Consequently, many of them grappled with the concepts of political and cultural power. ${ }^{13}$ To not understand musicians as intellectuals, or to ignore their music as evidence of their conscious examination of their social situation, would render an entire group of people historically inarticulate. ${ }^{14}$ In formulating these ideas, I am drawing on Eric Porter's arguments in What is this Thing Called Jazz? African American Musicians as Artists, Critics, and Activists, Elijah Wald's detailing of how music concepts and musicians traveled between Chicago and the rural South in Escaping the Delta: Robert Johnson and the Invention of the Blues, Burke's argument that the music was kept alive and innovative by a network of musicians in "Come in and Hear the Truth," and Samuel Floyd's presentation of the creation of tropes and lexicons in African American music in The Power of Black Music: Interpreting its History From Africa to the United States.

Seeing the musicians' movements and lives as being formed and informed by Chicago's history has required that I understand the connections between segregation, labor, and leisure activities in the city. I have 
situated my work between histories focused on the creation of institutional segregation, such as Arnold Hirsch's Making the Second Ghetto and Thomas Sugrue's Origins of the Urban Crisis, and the growth of the African American community, as examined by Christopher Robert Reed's The Rise of Chicago's Black Metropolis, I920-I929 and Adam Greene's Selling the Race: Culture, Community, and Black Chicago, I940-I955. Also important to my work are the histories of leisure, such as Robin Bachin's Building the South Side: Urban Space and Civic Culture in Chicago I890-I9I2, that understand areas such as the city's public beaches as sites of conflict. These authors attempt to appreciate how the city's power relationships played out in urban space and how conflict defined identities. The authors accomplish this by focusing on the history of urban planning, development, and involvement of community activists. I am building on their work by examining how social movements, as wide ranging as Progressives and white supremacists, purposely used segregation to regulate Chicago and how the culture created by musicians challenged the city's racial traditions.

To this end, a major goal of this book has been to map the spread of music spaces - such as nightclubs, street performances, and record storesand to create a data set that could explain and elucidate the demographic makeup of the musician community. I compare the music landscape to the historical city, census, and Urban League maps that present the population in terms of ethnic and racial densities, thereby marrying music history to urban history. The many charts and statistics used throughout the study stem from a census of I,983 musician death certificates-I,6 I 8 white musicians and 267 Black musicians - collected by the American Federation of Musicians Union between I940 and the I970s. In these visual and statistical representations of Chicago's musicians, it is possible to observe the origins and characteristics of the musician community, as well as how the boundaries of the "black belt" became less distinct over time.

Understanding history in this way presents the possibility of thinking of Chicago as more than a city of neighborhoods or as a dialectical conflict between the natural environment and urban planning. Chicago is a city of people. Above all else, the history of African American musicians demonstrates how individuals remade the city and challenged the idea of the inevitability of neighborhoods, racial differences, and labor divisions. The sharp tensions that emerged from their affront to the established social order stemmed from battles over racial propriety and the emerging cultural influence of the laboring classes in Chicago at mid-century. 
This study takes up the relationship of segregation to musicians from the beginning of Chicago's strident system of physical segregation in the early part of the twentieth century to the development of a civil rightsstyle protest among Black musicians in the I960s. Chapter I, beginning with the emergence of the first Black-owned music venues in 1904 and the vice purge of 1912, argues that from the early years of the century through the start of the I940s, the musicians resisted the daily humiliations and limitations placed on their work by creating an autonomous cultural sphere in the city centering on the importance of community and racial pride. The building of the Black cultural sphere-defined by physical territory, Black leadership and ownership, collaborative cultural exchange, and a citizenry engaged in social criticism ${ }^{15}$-in the early twentieth century was a break with the previous generation of Black leaders in Chicago who would have found separate institutions abhorrent and accommodationist. Pragmatically, Black leaders in the I920s and I930s argued that the community needed hospitals and schools that would welcome them, as well as newspapers that would promote the values of the community-what historian Evelyn Brooks Higginbotham termed "The Politics of Respectability, ${ }^{\prime 16}$ - and agitate against racism. Leaders among the Black musicians mirrored the larger community's move toward resistance through self-sufficiency by establishing and strengthening the Black musicians' union local, the National Association of Negro Musicians, music education in Black churches and schools, and the emerging Black-owned music theaters.

At the time, recent migrants from the American South populated the Black neighborhoods in Chicago. They were part of a the first waves of a century-long migration pattern that diminished the southern Black portion of the nation's total population of African Americans from 90 percent in I9Io to 85 percent in 1920 and increased Chicago's Black population fivefold by I930. ${ }^{17}$ Many of the musicians discussed in this book were part of this migration. Generally, the classically trained were from southern cities, such as Memphis, and the blues, jazz, and gospel musicians were from rural areas, such as the Mississippi Delta.

It is important to note that although they may have differed in place of origin, class, and education level, the classically trained musicians and the blues, gospel, and jazz musicians did not see themselves as entirely separate groups. Racial segregation in Chicago was pernicious. The fact that the classically trained musicians lived and performed under the same conditions as the blues musicians because class, education, and genre were 
all trumped by the perceived physical manifestations of race, illustrates this reality. It was common for the classically trained to play in blues and jazz bands, and the members from the two groups united in the r96os to confront the segregation of the musicians' union. In addition, classical, gospel, jazz, and blues all coexisted in the same Black entertainment areas of Chicago. All Black-led genres were simultaneously commercially viable and enjoyed the same audience, at least until the I950s when the white teenage and college student audience began to grow. It was not unheard of for African Americans to attend an evening performance of classical and faith music in a church before going to hear jazz and blues in a club. The blending of genres and audiences was another manifestation of the influence of so many different types of people and musicians all migrating to and sharing a small piece of urban space, as both Guthrie Ramsey argues in Race Music, and George Lipsitz contends in Time Passages. ${ }^{18}$ Therefore, when thinking about Black musicians in Chicago, it is better to look beyond genres toward understanding the musicians as part of a community defined by vocation, artistic endeavor, and segregation. Furthermore, I am following the lead of Bakari Kitwana ${ }^{19}$ by choosing to capitalize "Black" throughout this book. I contend Black constitutes a group and is equivalent to African American, Polish American, Chinese American, and so forth. Conversely, I have generally placed "white" in lowercase when I use it as an adjective, such as in discussions of power structures, and prefer the terms European American, Italian American, or Jewish American, for example, when describing familial, national, or ethnic groups.

Like the majority of African American migrants, Black musicians in the I920s and I930s made their homes in the narrow strip of land known as "the black belt." It was located between the southern tip of downtown-known as the "South Loop" — and the Hyde Park neighborhood, home of the University of Chicago. This section would almost double in population from 44,000 in I9 Io to about 80,000 people in I920, and it would increase another threefold to 234,000 by I $930 .^{20}$

Chapter 2 fills in the spaces between these statistics by considering the lives of musicians as migrants during the I930s and I940s. Their oral histories, song lyrics, and memoirs suggest that in this period they went through a personal transformation in which they came to understand themselves as being musicians as opposed to having a sense of self defined by their labor as plantation workers, for example. The choice to migrate to Chicago was a subversion of the southern racial system that tried to 


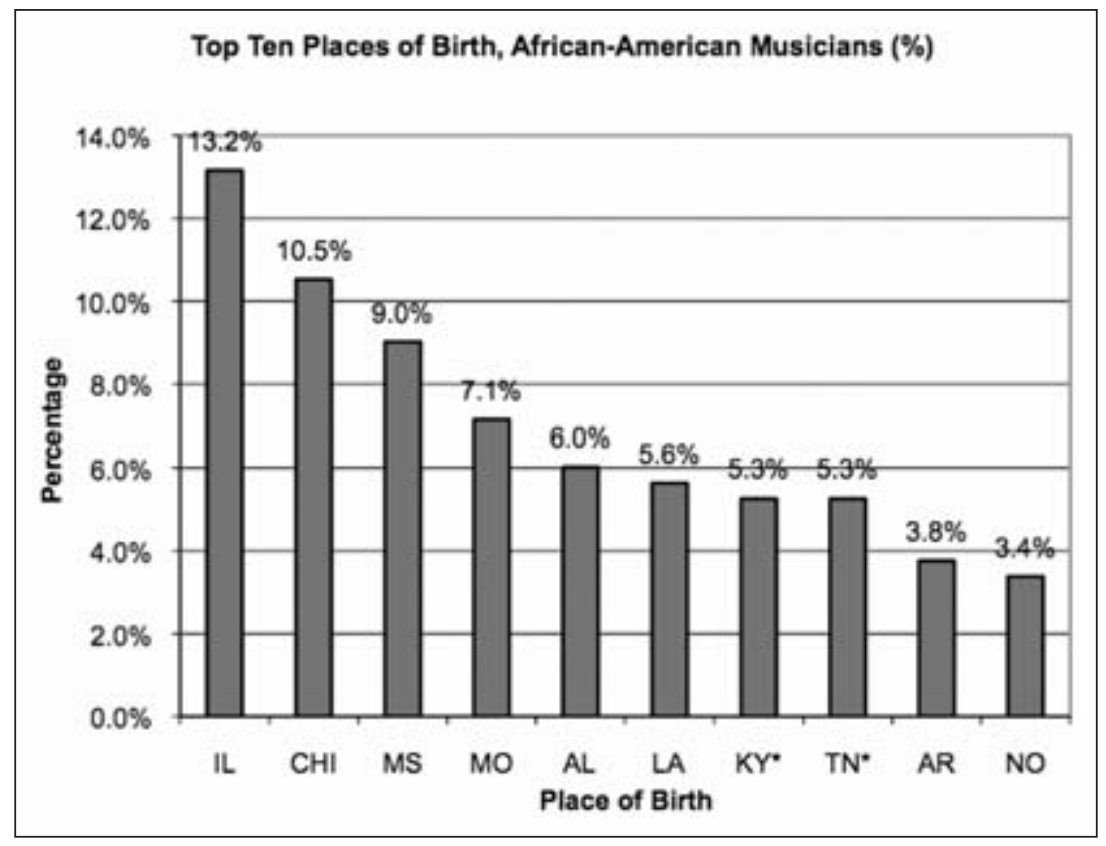

Figure I. The above graph, based on a study of 266 African American musician death certificates, shows that the largest groups of migrants, for whom a place of birth was known, were coming to Chicago from elsewhere in Illinoispossibly as second-generation migrants whose parents moved to Illinois from the South. Chicago-born musicians make up the second largest group. The balance of the ten places that ranked the highest in terms of African American musicians' origins were Mississippi, Missouri, Alabama, Kentucky, Tennessee, Arkansas, and the cities of Los Angeles and New Orleans. For I,573 white musicians for whom records exist, the breakdown by most common places of birth differs significantly, with more than I6 percent from those born in the ten most popular places coming from abroad: Italy, Russia, Brazil, and the former Czechoslovakia (includes the Czech Republic, Slovakia, and Bohemia) taking the last four places. The balance of the most common places where white musicians came from were Indiana, Wisconsin, Pennsylvania, and Missouri. 
control where they lived and the type of work they did. Once in the city, they would have to adapt the survival skills honed in the South to the urban racial system. On the plantations, the blues musicians resisted by becoming bootleggers and using their illegal drinking establishments to promote their music. These skills would serve them well in the city because they would have to develop a practical disregard for the physical barriers of discrimination, just as they had ignored prohibition in Mississippi, to make a living and to find housing in the city. The classically trained musicians resisted in both the South and Chicago by demanding a place in higher education and by bringing African American folk traditions to their classical compositions. They also used their professional organizations to demand anti-lynching laws and equality in public accommodations. While the efforts of the classically trained added to the Black cultural sphere in Chicago, still these men and women ached to play in the city's symphonies.

This discussion of the musicians' efforts to survive in Chicago builds on the history of the Black cultural sphere begun in chapter I. Musicians arriving in the I930s and I940s found a well-established music tradition and African American leadership in Chicago. New arrivals slowly changed that system, and called attention to the conflict that arose between those in support of the old system, those who wanted to ignore it, those who wanted to imagine improvisational social organizations, and those who wanted to challenge it continues throughout the book. This conflict did not follow generational or genre lines.

As this conflict unfolded, the demographics in the city continued to influence the course of African American life. At the start of the twentieth century, the foreign-born were the majority in Chicago. This fact was obvious in the street names, in the prevalence of Catholic churches, and in the city's political leaders. Following World War I, a shift began: the population of European-born Chicagoans began to decrease by onefifth each decade. By I950, the foreign-born population in the city and the African American population were equal in number if not in treatment. By mid-century, only New York had a larger Black population than Chicago. ${ }^{21}$ Urban League and census maps indicate that the African American population had by this point outgrown the Bronzeville neighborhood and was spreading out into the South Side (for example, into the Woodlawn and Englewood neighborhoods) with pockets located on the West Side and North Side (particularly in the Little Hell neighborhood). When combined with the increased wages and employment opportunities brought 
on by World War II, ${ }^{22}$ this growth in the Black population of Chicago was an indication that African Americans were becoming an economic and political force in the city.

With the demographic increase and subsequent growth in cultural visibility as its backdrop, chapter 3 argues that in the late I940s and the early I950s, a small group of Black blues musicians turned toward "the market" as a means of resisting segregation in the music industry. In cooperation with South Side independent music producers, the musicians recorded and released music during the 1948 ban instituted by the American Federation of Musicians' union on recording new music. The musicians were members of the musicians' union, but they did not obey the strike because they realized that the lack of any competition in the market place, due to the ban, meant that Chicago's South Side music briefly was the market. By 1953, these musicians had come to thrive. Chicago musicians-namely, the blues musicians-were positioned to have this impact on the nation because Chicago was a leader in the recording, distributing, and broadcasting of popular music.

Latino and European American youth, from California to New York, began buying Black recordings in such large numbers by 1953 that Chicago's music transformed from a regional phenomenon that united the Midwest with the South into a national music trend. White disc jockeys began adopting Black urban syntax and slang to better align themselves with the emerging importance of Black culture. The success of the South Side's music sent the large music corporations scrambling to understand the shift in the music and to find a way to regain control of the audience as well as the market. The national rise in the popularity of Chicago's Black music was the most successful challenge to segregation undertaken by the musicians since their arrival in Chicago.

Nevertheless, as chapter 4 argues, there was a downside to fame. A National popularity meant that Chicago's Black musicians had broken through the physical barriers of segregation that had prevented them from playing or distributing music beyond the Black neighborhoods in the urban centers and in the South. As they toured promoting their music, they took with them the racial pride they had built up in Chicago and found themselves less willing to acquiesce when faced with the old-time traditions of southern racism while on tour. Many considered their tours a purposeful intervention into southern racism. When their racial pride was combined with the fact that they were drawing European American teenagers in larger and larger numbers to their performances, Chicago's 
Black musicians found themselves under the constant threat of violence, arrest, and censorship.

Chapter 4 focuses on the mid-I950s debate concerning the musicians' success by discussing what happened when the tried-and-true physical barriers of segregation were no longer effective. Black music was perceived as a threat to American culture, according to the segregationists, because white teenagers were actively seeking out Black music; radio stations were broadcasting it across neighborhood, city, and state lines; and previously white venues were booking Black musicians. Southern segregationists fought back by physically attacking the artists, raiding interracial venues, and vandalizing radio stations. Throughout the country, community groups pressured radio stations and jukebox owners to limit Black music. The ire over the rise in national popularity of Chicago's Black culture was even addressed by Congress, which held hearings regarding the perceived corruption of independent music producers and disc jockeys. The controversy over the appropriate audience and place of Black music in the I950s was similar to the Progressive-led "vice crusades" of the I9IOs and I920s (discussed in chapter I) that conflated race, crime, and music. Two differences between the I920s and the I950s spread of Black music was the role of technology in the wider distribution of Black music in the I950s and the growing influence of the civil rights movement on both the musicians and the audience. As the musicians' popularity grew, so did the segregationists' violence against the Black musicians.

African American musicians in Chicago knew that destroying segregationists' attempt to control Black cultural power was not just about demanding artistic freedom. There were strict limits placed on where they could play in the city, what jobs they could hold, and with whom they could perform. Recording companies, broadcasting companies, and the American Federation of Musicians union supported these inequalities. Therefore, as the I950s ended, it was apparent to many in the musician community that there would have to be an organized assault on the foundations of segregation.

In 1963, as explained in chapter 5, a group of about 200 African American musicians, a minority within the Black local, responded to the system of segregation by questioning the existence of segregated union locals and the importance of there being an autonomous African American cultural sphere in Chicago. The union locals had been supporting the practice of segregated locals since I902, whereby part of the city was designated for white musicians (the North Side, downtown, the radio stations, and the 
symphonies) and the other part (the "black belt" and South Side) for Black musicians. The 200 hoped that by dismantling the decades-long tradition of segregated union locals, they would destroy the cultural and economic segregation of the city. They believed that if the union demanded that broadcasters and venue owners employ them, and if the union would fight for equal contracts with recording companies, then they would advance economically and enjoy greater creative freedom. Their rhetoric accused the Black local's leadership of supporting and promoting segregation in the union to secure its own power in the community.

The musicians wishing to end segregation had opponents in the Black union local. Among them were the local's leaders who embodied the early twentieth-century idea that autonomous and self-sufficient Black institutions were an attribute and a necessity to supporting and protecting Chicago's Black community. ${ }^{23}$ The union leaders believed that in insisting on segregation, whites had inadvertently created Black spaces, such as nightclubs, that fostered the development of the Black community's identity and culture. ${ }^{24}$ The position held by the Black union leaders stood in striking contrast to that held by the 200 who believed that an all-Black leadership could be as dissatisfying as an all-white leadership.

For the entire history of the Black local-and for that matter, the musician community - there had been those who pushed more for autonomy and those who pushed more for integration. Yet, there were other choices, such as leaving the city or being pragmatically autonomous by following union rules when they were advantageous. The I960s, and the civil rights movement and legislation, forced the discussion of integration and eliminated discussion within the union hall of the indirect methods of resisting, such as ignoring all union and civic rules by creating new music spaces or exploiting the chinks in the lines of segregation, which defined the daily life of the rank-and-file members of the Black local. Instead, the fight became about who would author integration and whose interpretation of the history of musicians in Chicago would win out. In this I96os context, those who had built the union local saw themselves as having done so as a response to racism in the white local. They were standing their ground as a bulwark of the community, and as the African American musicians' only chance for representation in the union and in the city. The 200 disagreed and demanded immediate integration. The subsequent debate illuminates the major themes of this history, including the links between physical and cultural segregation in the city, because it was as much about where the musicians were allowed to play as it was about 
bandleaders having the freedom to hire musicians regardless of skin color and to record music of their choosing. The musicians' discourse also articulated the larger issues of integration in Chicago, such as the possible loss of distinct identities and communities, which they had been building since the first migrant musician arrived in the city, the lack of representation in a white-dominated union and city, and the very real possibility that integration would be just a new form of oppression. 
CHAPTER I

\title{
Musicians and the Segregated City
}

\author{
Chicago in the Early I900s-I930s
}

$\mid \begin{aligned} & \text { n I904, Joe Jordan composed "Pekin Rag," a work dedicated } \\ & \text { to the dance hall that would over time become Chicago's }\end{aligned}$ Black-owned Pekin Theater. The cover of the sheet music for "Pekin Rag" features a photograph of the crowds inside the theater. Filling the foreground are the musicians, dressed in matching uniforms. The audience stretches out behind the orchestra, filling the floor and the balcony of the theater. All of the men are in dinner jackets and the women are dressed in gowns. Chandeliers hang from the ceiling and mirrors adorn the walls.

The sheet-music photo only hints at the early grandeur of the Pekin, which owner Robert Motts remodeled and reopened in 1905 and 1906 as a large-scale theater. Eventually, the Pekin, located on the 2700 block of South State Street, housed a touring company and orchestra capable of supporting operas as well as popular music performances. Its significance as a venue grew as the Black neighborhoods surrounding it grew. It became so important to the community that Black leaders endorsed the Pekin as a shining example of African American art and culture. ${ }^{1}$ Further endorsement of the Pekin, and the music culture that emerged around it, came from Catholic nuns who brought orphaned African American children to the Black theater district to watch the performances so that the children could see their community in the most positive possible light. ${ }^{2}$

A photo of the outside of the Pekin suggests a different perspective on the theater that was a jewel of the Black community. In an era when Chicago was becoming defined by skyscrapers and architectural filigree, externally, the Pekin was a stark brick building with storefront windows. Like nearly every other building on the South Side, the Pekin had only 
two stories. There were no trees lining the street in front of the theater, nor was there a line of cars. The emptiness of the exterior photo, in contrast to the photo of the interior, reveals that the Pekin's neighborhood had access to few of the civic services or comforts common on the city's North Side.

The neighborhoods surrounding the Pekin were home to a growing population of 44,IO3 African Americans in I9IO. By I920, there were I09,594 African Americans in Chicago. The growth in the Black population represented a significant demographic shift in the city-which had a total of 2,70I,705 residents in I $920 .{ }^{3}$ City commissioners concluded in 1922 that the increase in the African American population was staggering, but it was not a citywide phenomenon. Rather, it represented an increase in population density that pushed at the borders of the existing Black neighborhoods south of the downtown business district. ${ }^{4}$

The two photos of the Pekin captured the dual reality of the South Side. It was an area of the city disregarded by civic leaders in terms of development while simultaneously being a site of civic pride for African Americans. The reason for this contact was that African Americans were slowly building an autonomous cultural sphere on the South Side where they could be the venue owners, the musicians, and the audience-which is the essence of the photo capturing the interior of the Pekin.

The conscious use of self-sufficiency as a way to resist segregation was at the heart of the complex relationship African Americans had with Chicago. The Black cultural sphere ensured the promotion of African American culture, but it ran the risk of legitimizing the city's racial politics. It also necessitated that the Pekin's owners, ignored by city leaders and banks, turn to the city's crime syndicates to underwrite the theater. By the early I920s, the onetime jewel of the community became infamous as a resister of Prohibition laws and a venue for gang violence. In the minds of many Chicagoans in the I920s, the Pekin was an example of the connections between crime and African Americans. The Pekin illustrates that it was impossible to resist segregation without being shaped by segregation. ${ }^{5}$

In the forefront of the conflicts and contradictions born of the African American struggle against segregation in Chicago, as the photos of the Pekin demonstrate, were the musicians. African American musicians began to arrive in Chicago in considerable numbers in the early I9ros. They were attracted to Chicago in part because of the Pekin and what it represented. The musician migration collided with a political movement 


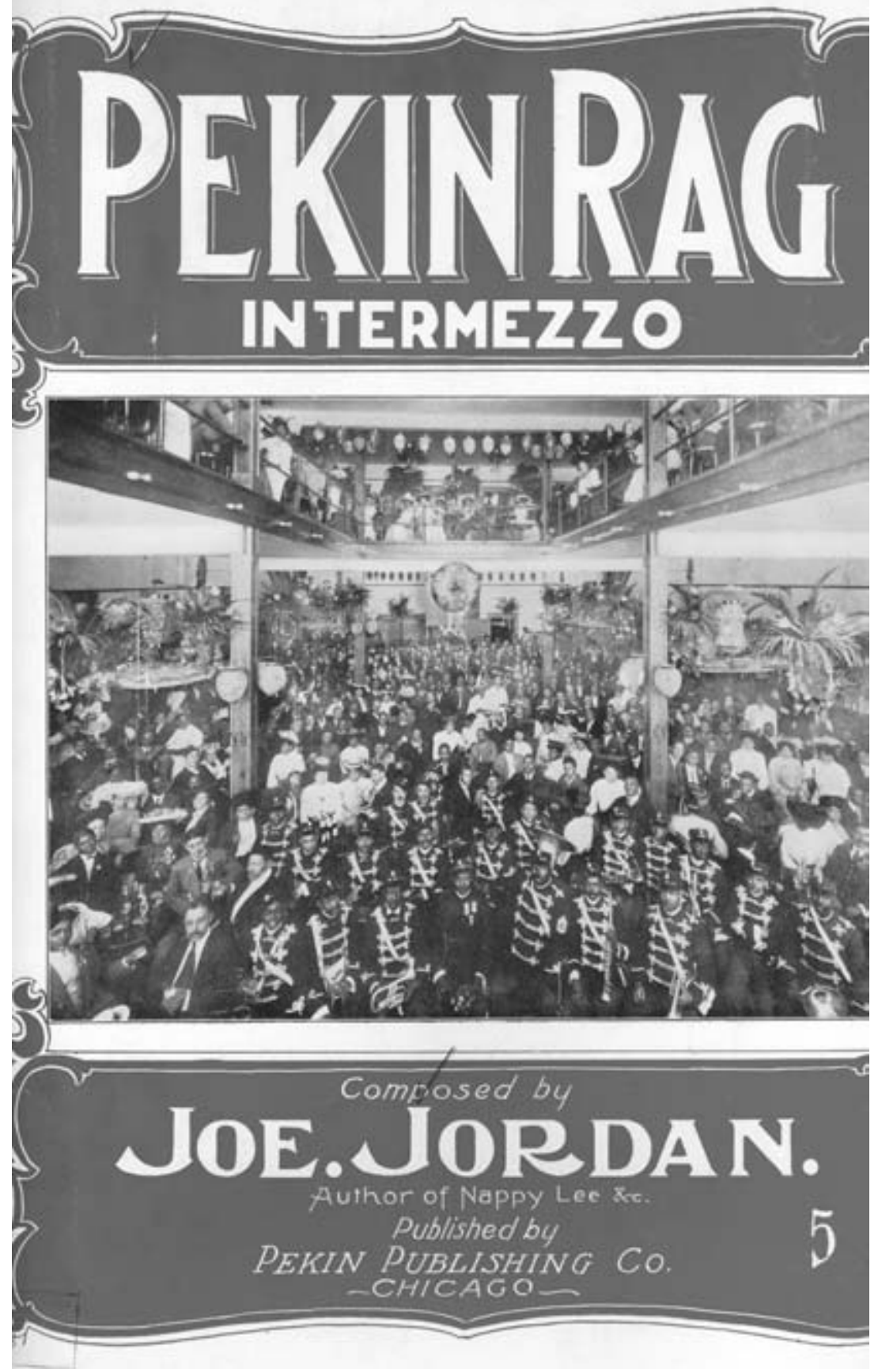

Image I. "The Pekin Rag," I904. Courtesy of the Music Division of the Library of Congress. 


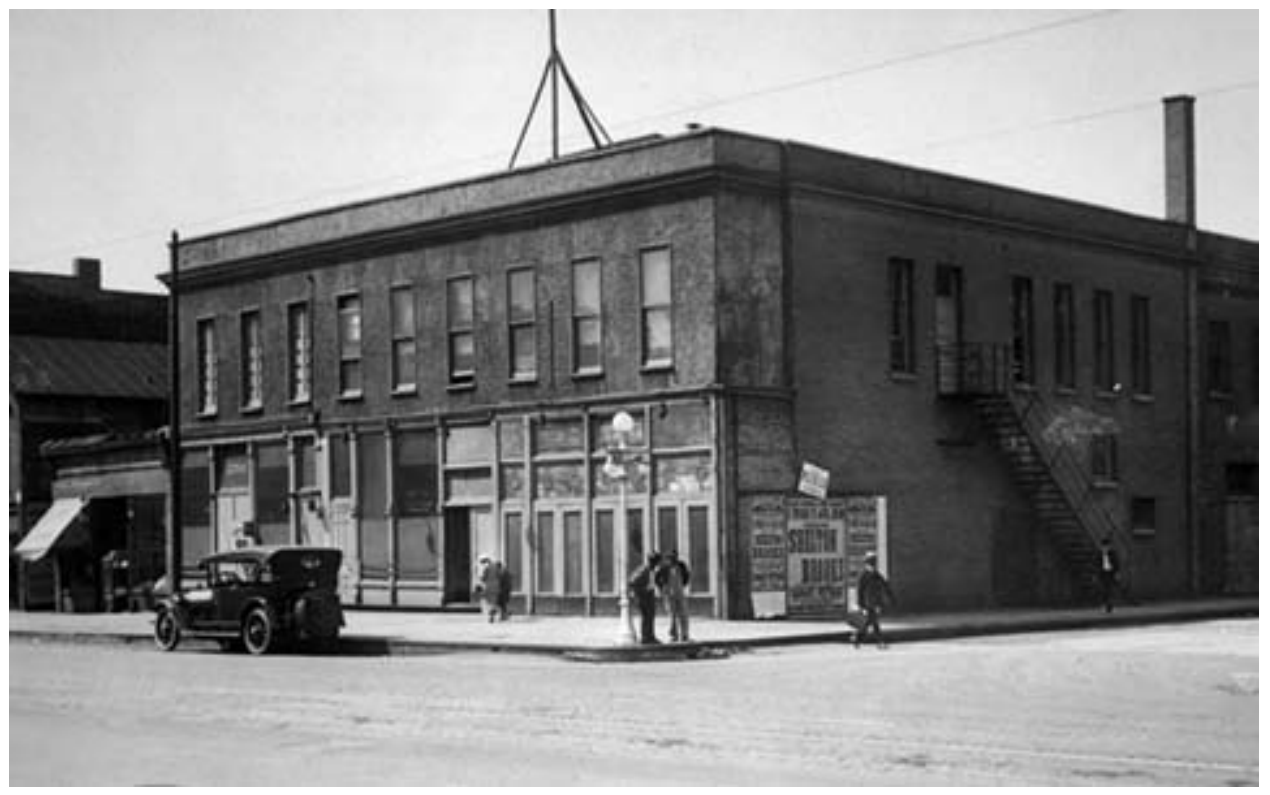

Image 2. The Pekin Theater Building. Property of the Chicago History Museum.

in which Chicago leaders were turning more toward using physical segregation as a tool to contain the city's booming "vice" businesses and the growing African American population within the same area of the city. Rather than ending vice, civic leaders pushed brothels, saloons, dance halls, and gambling establishments into the least politically powerful part of the city: the emerging South Side "black belt." Because much of Chicago's popular music was performed in the venues of vice, such as bars and brothels, the majority of the city's popular music clubs also relocated to the "black belt." By the end of the I930s, African American musicians had seen a transformation of Chicago in which the legitimacy of venues, like the Pekin, slowly eroded under the pressure of the vice purge until they, too, were venues of vice.

The history of the growth of segregation in Chicago stands side by side with the history of the growth of African American culture in the city. Black musicians were caught between these two historic forces. To survive, all Black musicians would have to defend their music and their profession from the social stigma resulting from the vice purge that pushed 
vice into the South Side, which threatened to reduce their music to an element of crime. The Black musicians' opponents included both white social crusaders, seeking to drive out popular music venues, and African American leaders, striving to build a "respectable" Black cultural sphere on the South Side.

\section{THE PLACE OF VICE AND MUSIC IN CHICAGO}

Three forces shaped the musicians' reality in Chicago in the early twentieth century. The first was the I9I 2 vice purge. Around the turn of the century, before the creation of the "black belt," pulp novelists and religious leaders described the places of vice in the city as the Customs House in the Loop, the Chinatown neighborhood south of the Loop, the Levee of the near South Side, and the Little Hell neighborhood north of the Loop. These areas were the "slums of vice," characterized by dice games, prostitutes, opium, and ragtime that "grated on sensitive ears." None of the pulp descriptions of these places referred to African Americans. The only descriptions of racial mixing concerned Chinatown and focused on the relationship between opium, Asians, and European Americans. These early descriptions of Chicago suggest that there was a connection between popular music and vice before African Americans started to arrive in Chicago in large numbers.

The process by which African Americans became tied to notions of vice was a historical process rooted in the policing of the Levee. As Chicago's red-light district, the Levee emerged in the I870s on Wabash Street close to the downtown business district-the Loop. It was a redlight district notorious for its saloons, dance halls, brothels, and displays of sexuality that were often interracial, cross-class, public, and commercial. It was a place of social experimentation where people from different backgrounds could mix and touch one another without concern for social propriety.

In the early I900s, the police began to focus on the Levee. The surveillance and prosecution caused the district to begin to creep further and further south, from the downtown commercial area to I8th and 22nd Streets between State and Armour. Though the drift had been underway for awhile, it was not until I9I I that the conscious plan to force vice into the Black neighborhoods began with the Vice Commission's report. 
At the core of its arguments was the Levee. The commission viewed this section of Chicago as a vice bacillus branching out into the city. ${ }^{6}$ In the report, the Vice Commission observed that vice was always "within or near the settlements of colored people.... Where ever prostitutes, cadets, and thugs were located among white people and had to be moved for commercial and other reasons, they were driven to undesirable parts of the city, the so-called colored residential sections." Underlying their words was the growing idea that vice in the Black neighborhoods was natural in an urban space. ${ }^{?}$

Chicago civic leaders were not alone in the war on vice. In Seattle, the city's women pushed for the recall of Mayor Hiram Gill, charging him with corruption because he supported a legal vice district in the city. ${ }^{8}$ In the Arizona and the New Mexico territories, the public debate concerned Prohibition, the need to recall corrupt judges, and women's rights. ${ }^{9}$ Throughout Ohio, the police and city leaders blamed Black communities for vice and refused to distinguish between criminals and law-abiding African Americans, which resulted in violence and an increase in the incarceration of Blacks. ${ }^{10}$

Chicago civic leaders were also not alone in looking to segregation as a way of controlling the ever-increasing African American population in the city. This was the age of Jim Crow. Between I900 and I9I I, there was a marked increase in residential segregation laws throughout the South, and the residents of Atlanta took things a step further by segregating elevators. In Harlem in I9I2, white residents were calling for "Jim Crow" cars in the city trains because they disliked the striking growth in the number of Black residents in the neighborhood. Furthermore, large-scale race riots marred each presidential election. The I9I 2 election reflected the growing tension in the nation when Theodore Roosevelt's Bull Moose Party refused to seat duly elected Black delegates, suggesting that the Progressive movement was for whites only. ${ }^{11}$

Chicago's vice crusade and turn toward segregation stands out in this moment of social reform because it was legitimized and endorsed not only by city and civic leaders but also by social scientists at the University of Chicago, which gave the vice purge the auspices of a city-planning measure. Their rationalizations illustrate the divided nature of their plan for the city. On the one hand, they were attempting to apply the progressive ideals for which the city had become famous. On the other, their inconsistencies and the uncertain terms regarding vice and race reveals 
that in I9I2 they were starting down the path of creating two Chicagos dominated by different political and cultural ideas. ${ }^{12}$ In the end, the Chicago commissioners, politicians, and police did not succeed at preventing or eliminating vice. Instead, they pushed vice further into the "black belt." 13 The physical segregation of vice in the racially segregated "black belt" became the answer only after it was apparent that the reformers could not eradicate vice any more than they could stop the growth of the African American population. Once in the Black neighborhoods, the vice areas would comprise the borderland between the neighborhoods of the Black elites and the areas controlled by poor European American

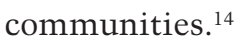

The vice purge resulted in two significant developments. First, the purge designated the South Side as the neighborhood of vice. Following the purge, the majority of the musicians playing jazz and blues in Chicago, and those who would migrate to the city over the next few decades, relocated to the South Side because the music venues were economically tied to the "pleasure palaces," "resorts," and "dives" controlled by crime syndicates. Black music - and, by extension, the Black musician-were seen as the accomplice of vice. The purge created a situation in which even the classically trained African American musicians found it difficult to perform beyond the South Side. The type of music the musician played was unimportant. The musician's physical appearance became the determining factor rather than class, genre, or education. Second, the vice purge was a manifestation of the growing need to control the city through segregation. Civic leaders knew that they could not end vice, and so they turned to segregation as a way of managing the city. ${ }^{15}$ The choice to physically segregate African Americans and vice from the rest of Chicago, therefore, inextricably linked race and vice in the minds of the majority of Chicagoans.

The vice "crusade" did not so much destroy the Levee as shatter it. Its pieces reassembled in the predominantly African American neighborhood on the South Side, where the vice district gained a new name and a new social significance as the geographic center of African American music and business in Chicago. This area, between 26th and 39th Streets, encompassing South State Street and including the Pekin, came to be known as the Stroll.

Orchestra leader and composer Duke Ellington described the Stroll of the I920s as a place of racial unity without "hungry negroes" or "uncle Tom negroes." He described the population by saying: 
It was a real us-for-we, we-for-us community. . . . It was a community of men and women who were respected, people of dignity-doctors, lawyers, policy operators, bootleggers, bankers, beauticians, bartenders, saloonkeepers, night clerks, cab owners, cab drivers, stockyard workers, owners of after-hours joints-everything and everybody, but no junkies. ${ }^{16}$

While Ellington celebrated the diversity of classes and businesses, the Stroll was a place of concern for the Black business leaders wishing to cultivate a respectable image of the community. ${ }^{17}$ To the white press of the I920s "the ghosts of the long gone days of Chicago's roaring levee" haunted the Stroll, where "the society man, the chorus girl, the gangster, the lawyer, the jazzbo" could all be found. ${ }^{18}$

The concepts of community, lawless vice, and respectability were all present on maps of the area. This is because the Stroll was a place where Chicago's world of vice and crime overlapped with the businesses of the industrious middle class. It was well-known that the city's crime syndicates, such as that ruled by Al Capone, controlled the nightlife. ${ }^{19}$ Capone's neighbors in the Stroll were banks and insurance companies. Further complicating things, the theater and cabaret proprietors of the Stroll, such as the owner of the Pekin, purposefully worked to distinguish themselves from the Levee by attempting to establish a high level of décor and entertainment that rivaled the stylish theaters and halls that served white clientele downtown. ${ }^{20}$

Despite the furnishings, the area remained a challenge to propriety because owners and visitors to the area mixed vice with amusements by creating a space of racial integration. ${ }^{21}$ Both whites and Blacks took part in the music, dancing, theater, prostitution, and other entertainments available in the area, making the Stroll, just as it had made the Levee, a target of both Black and white reformers. In this way, during the period between World War I (when jazz musicians migrated to the city following the closing of the red-light district in New Orleans) and 1927 (when the Savoy Ballroom, which was the first high-class establishment to not be built on the Stroll, opened), the Stroll quickly became the embodiment of all of the complexities of African American life in Chicago.

There were also music venues in Chicago outside of the Levee and the Stroll, including downtown clubs like the Royal Gardens, which welcomed a mixed audience in the late I9IOs. This situation would change quickly. ${ }^{22}$ At the time, it was becoming more and more common that 


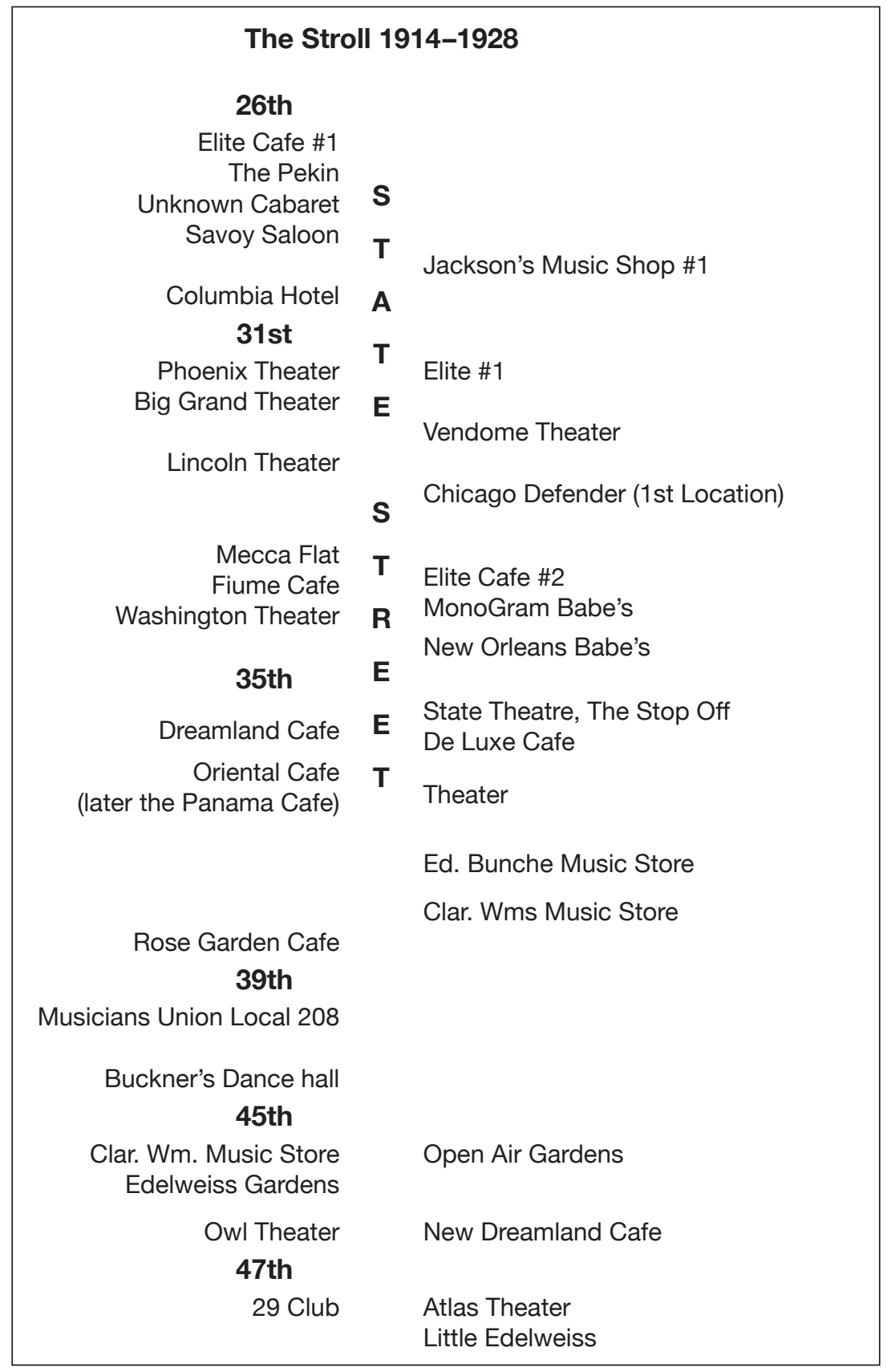

Map I. The map is based on a hand-drawn representation of the Chicago Black music scene from I9I4 through I928, created by critic Eduard Miller and musician Richard M. Jones. Esquire's Jazz Book, I946 (New York: A. S. Barnes and Company, I946), from the Paul Eduard Miller Papers, Center for Black Music Research, Columbia College, Chicago. Created by the author. 


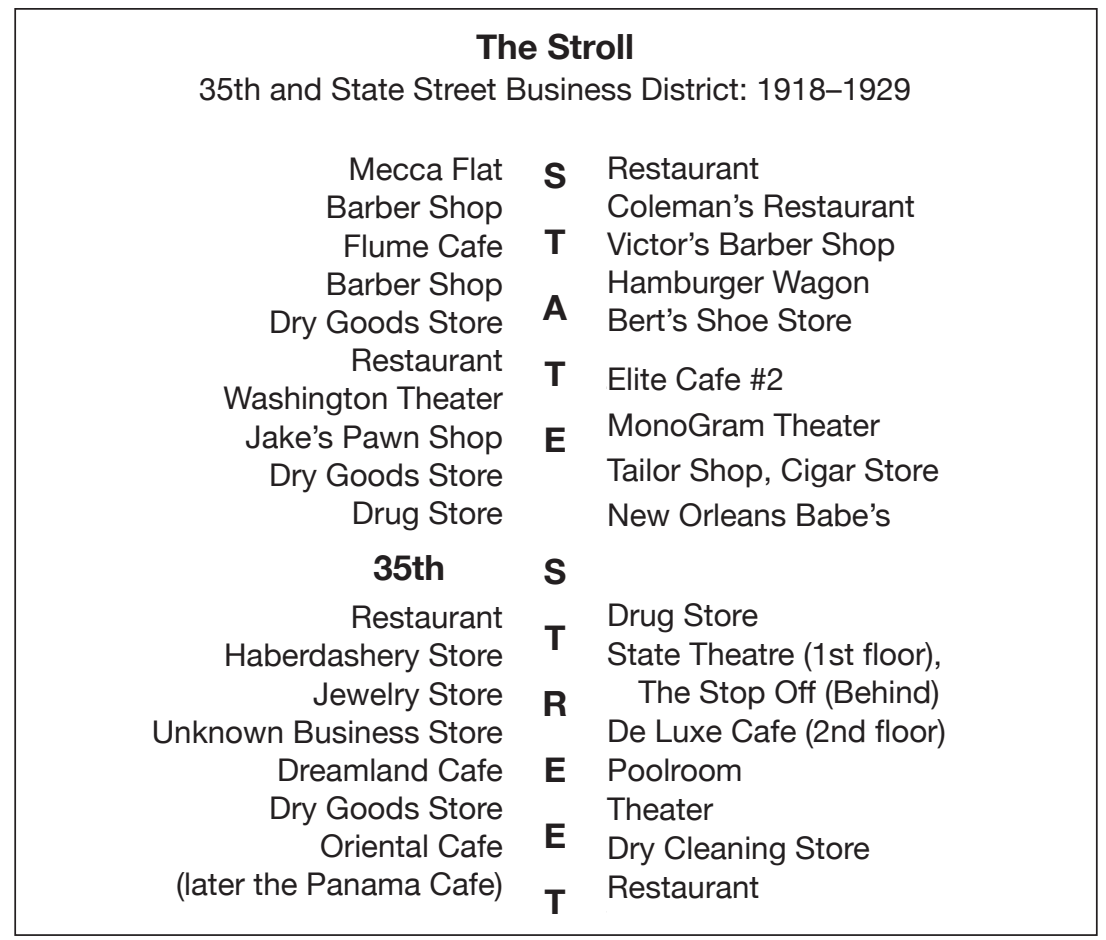

Map 2. The Stroll at 35th and State Street, based on Miller's map. Miller's map is an invaluable source because as a music critic he knew the locations of the illegal after-hours clubs-such as the Fiume, where Louis Armstrong playedas well as the clubs that advertised in the newspapers. Also, Miller was careful to preserve in his map the fact that banks, insurance companies, and all manner of legitimate businesses surrounded the entertainment venues. Miller's map is one of the best illustrations of the importance of this area of the South Side to the Black community. Created by the author.

African American audience members were refused tickets or sold tickets for the balcony. It was also increasingly customary for African Americans to be sold tickets only to have ushers refuse to seat them. Often, African Americans sued the theaters for damages on the grounds that such treatment violated the state's antidiscrimination laws. In the I9Ios, African Americans were successful in court, but by 1925 these kinds of suits were struck down, signaling a change under way in the city. ${ }^{23}$ These court cases represented the growing contradiction between Illinois state laws banning discrimination in public spaces and the lived experience of African Americans in Chicago. 


\section{THE PROBLEMS OF VICE AND RACE}

The second force that shaped the Black musicians' experience in Chicago was the rise of the "social myth" conflating race and vice, which was solidified by the vice purge and fed by the increasing racial tensions in the city. African Americans came to Chicago during World War I to work in the growing number of industrial jobs created by war demand. Throughout the war, there were few new buildings constructed in Chicago, ${ }^{24}$ which resulted in African Americans living in conditions "lacking" in the "conveniences, considered necessities by the average white citizen." The housing disparities included the absence of bathrooms. If there was plumbing, then there was no hot water. Also, Black families had gaslights rather than electricity and wood stoves rather than furnaces. ${ }^{25}$

As the numbers of African Americans increased they pushed at the boundaries of the "black belt" and moved into areas along the periphery of the segregated zone that at the time ran from the southern end of the Loop to the edge of the Kenwood neighborhood north of the University of Chicago. ${ }^{26}$ Purchasing a house in the Woodlawn neighborhood, south of the University of Chicago, for example, meant that families could live in homes free from rat infestations in conditions "much as whites do." ${ }^{\prime 27}$ However, the expansion of the "black belt" put African American migrants in direct conflict with the whites in those areas.

Nowhere was the racial conflict more evident than in the Kenwood and Hyde Park neighborhoods nestled between two predominantly African American neighborhoods-what would become known as Bronzeville to the north and Woodlawn to the south-and the University of Chicago. In I9I0, Blacks comprised only i I percent of the Bronzeville population and 6 percent of Woodlawn. However, by I920, African Americans comprised 25 percent of Bronzeville and I 4 percent of Woodlawn. ${ }^{28}$ The growth of the African American population frightened the non-Black residents of Kenwood and Hyde Park. Simply put, they felt surrounded by the racial other whom they believed were synonymous with moral declension.

Motivated by fear, white residents looked to homeowners' associations to guarantee that Kenwood and Hyde Park remain "white-only." 29 Indeed, one homeowners' association declared that "Any property owner who sells property anywhere in our district to undesirables is an enemy to the white owner and should be discovered and punished." ${ }^{\prime 30}$

Dozens of African American homes in the former white neighbor- 


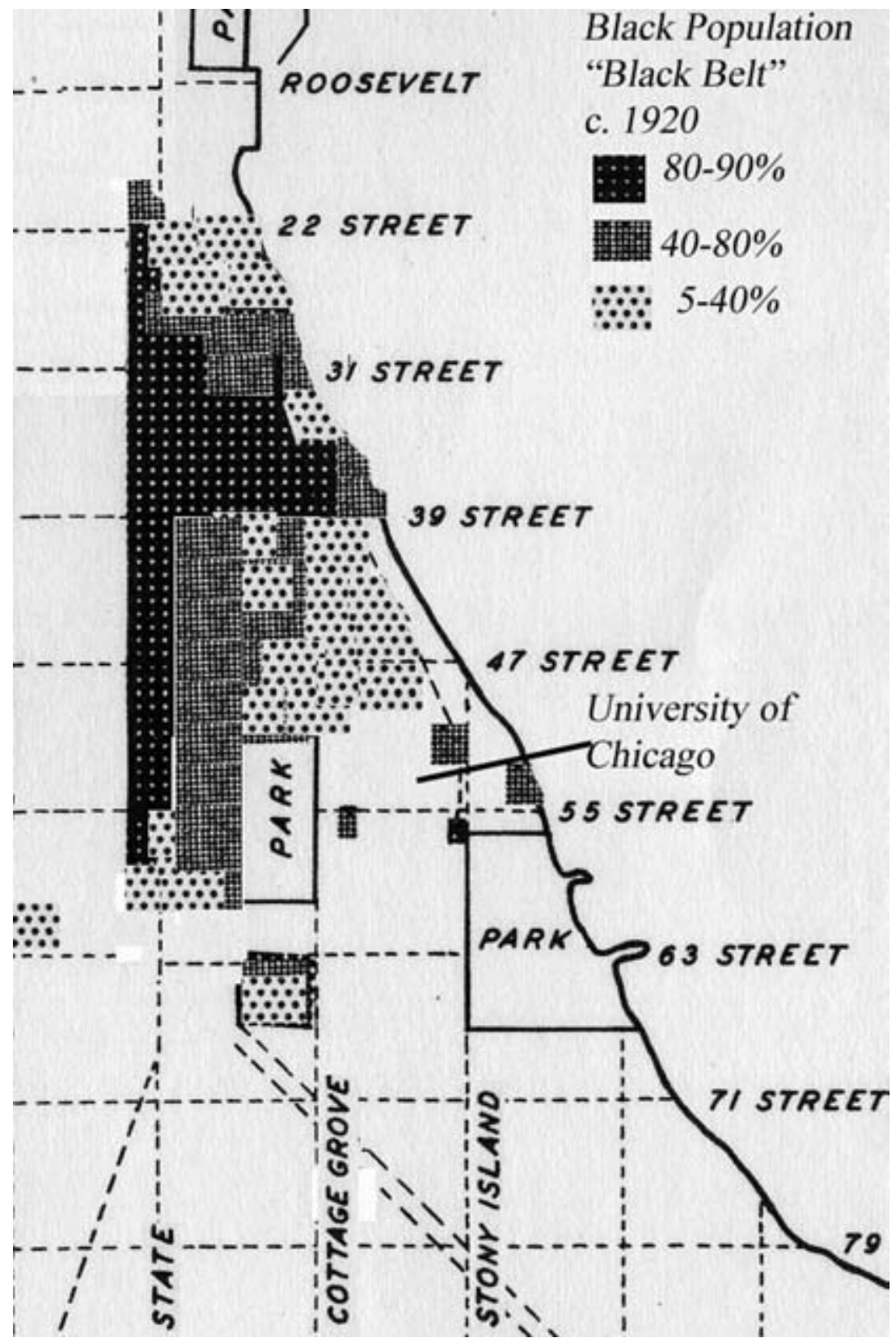

Map 3. The Black Belt, c. I920. Based on I920 census data and the Race Commission's Report. Created by the author. 


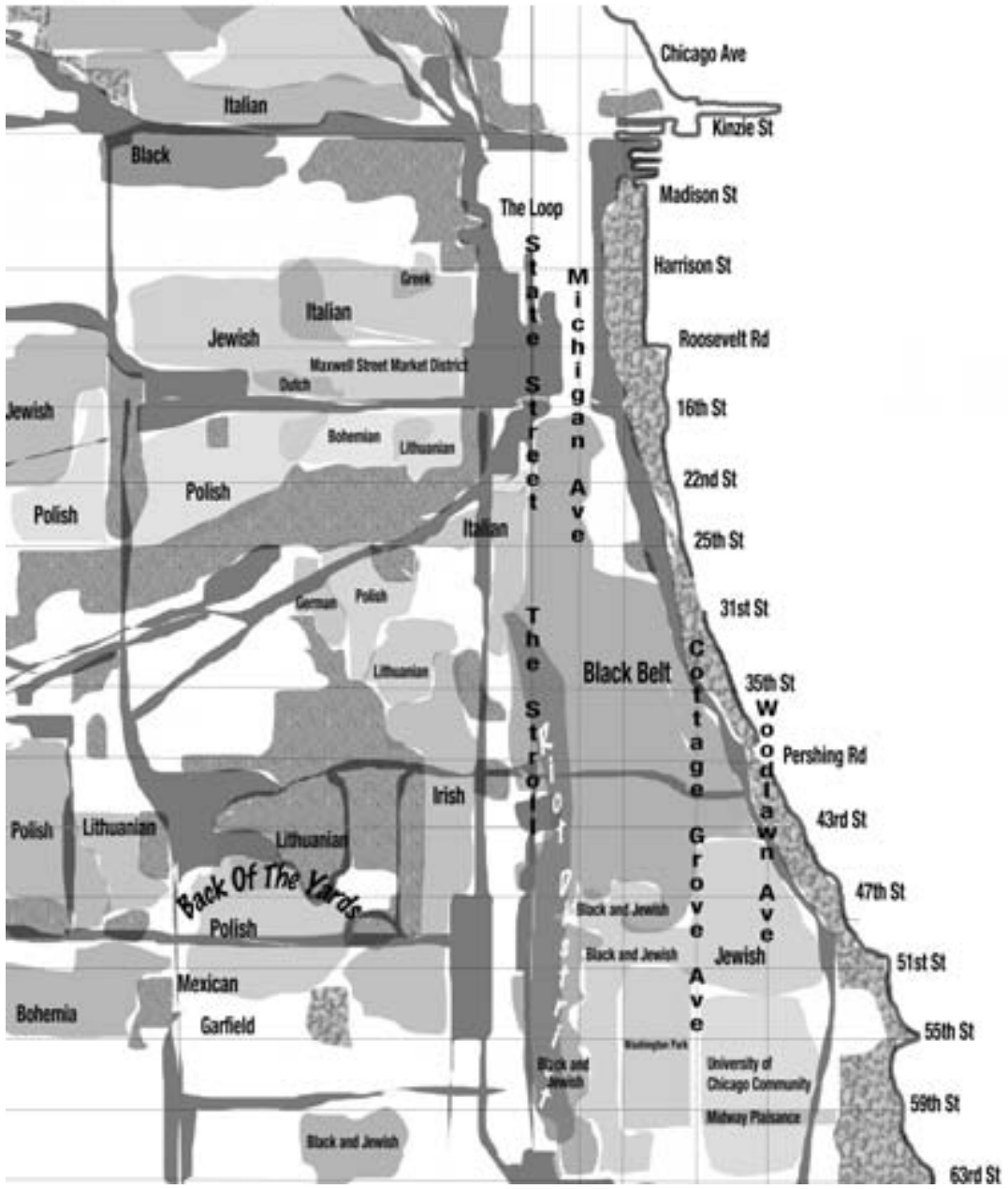

Map 4. This map indicates the geographic relationship of the "black belt" and the ethnic neighborhoods. For a young Black man, such as Langston Hughes, drifting beyond the boundaries of the "black belt" was an action fraught with danger, as large numbers of white street gangs patrolled the perimeters of the neighborhood. For the music venues, running a business meant negotiating the political landscape that arose from the crime and vice of the city. The above is based on maps that appeared in Frederick M. Thrasher's The Gang: A Study of I, 3 I 3 Gangs of Chicago (Chicago: University of Chicago Press, I936). From the Map Library, Regenstein Library, University of Chicago. Created by the author. 
hoods were bombed in I9I9 and I920 in response to the breaking of the segregated housing lines. ${ }^{31}$ In addition, white street gangs patrolled the borderlands between the Back of the Yards neighborhood-home to the meatpacking plants and a large number of immigrant families-and the western edge of the "black belt." These gangs frequently attacked and brutalized African Americans in this area. One of the victims of the attacks was young Langston Hughes. In his autobiography, The Big Sea, the leading African American writer recalled accidentally walking beyond the boundary of the "black belt" in the spring of I9I8. A white street gang attacked him. He returned home with "both eyes blackened and a swollen jaw." ${ }^{\prime \prime 2}$ Hughes was one of the lucky ones because a year later, during the spring of I9I9, the gang attacks on Blacks climaxed with two murders. This led the chief of police to send several hundred extra officers into the area to prevent racial violence. ${ }^{33}$

The increase in the African American population had consequences for the political system as well. Mayor "Big Bill" Thompson worked with African American politicians to ensure that Black Chicagoans were part of the ward system. The result was a reelection victory for Thompson and the Republican Party in 1919. Black support for Thompson was conspicuous and contributed to whites' fear that African Americans had gained too much political power in the city's patronage system. It did not help matters that Thompson accepted payments from vice operators and was a frequent patron of the very clubs that the Vice Commission had decried. The mayor's corruption further stigmatized African Americans. ${ }^{34}$

White fear of the increase in the African American population, political power, and physical territory in the city was a contributing cause of the I9I9 race riot. The riot began when an African American youth swimming in Lake Michigan drifted to the white side of the swimming area. Whites on the beach began to throw stones at the youth, and they did not stop until they had drowned him. A beat cop at the scene allowed whites to throw the stones and prevented anyone from entering the water to aid the boy. Word of the murder spread quickly. A group of African Americans marched toward the line of segregation. They converged on the beat cop, who summoned other police officers. A group of angry whites joined the police. These events set off thirteen days of violence, which included seven days of rioting and nearly an additional week of police raids and mass arrests, in which nearly all elements of civil society were abandoned. There had not been a riot in Chicago since the Haymarket Riot of $\mathrm{I} 886 .{ }^{35}$ If civic leaders wished to forestall future race riots, they would need 
to know what caused this violence and how to control racial tensions. Immediately following the I9I9 violence, the city government created the Chicago Commission on Race Relations. Its study, published in 1922 as The Negro in Chicago, concluded that there existed a powerful "social myth" that confused being African American with being a supporter of vice.

The commissioners noted the prominence of this "social myth" in the Chicago newspapers' reporting on vice. Examples included the exaggeration of arrest rates of African Americans and the promotion of the belief that riots began in dance halls and other venues of racial mixing. The press fed the public outrage with provocative descriptions of the clubs.

The crowd began to arrive. In came a mighty black man with two white girls. A scarred white man entered with three girls, two young and painted, the other merely painted. . .

Seven young men-they looked like back o' the Yards-came with two women. ...

Two fur-coated "high yeller" girls romped up with a slender white man. An Attorney gazed happily on the party through horn-rimmed glasses....

At one o'clock the place was crowded . . . a syncopated colored man had been vamping cotton fields blues on the piano. A brown girl sang. . . A All the tables were filled at two o'clock, black men, with white girls, white men with yellow girls, old, young, all filled with abandon brought about by illicit whisky and liquor music. . . ${ }^{36}$

Terms such as "brown girl," "high yellers," "yellow girls," and "syncopated colored man" were phrases used by the papers to characterize African Americans in the club by their shade of skin color, which was an indication of racial mixing in their genetic past. The description of the African American patrons, paired with the descriptions of the "slender white man" and the seven men who looked like "Back $\mathrm{O}^{\prime}$ the Yards," suggests many of the couples were racially mixed and that the club was mixed in terms of class. From musicians' memoirs, it is also known that the bands were mixed racially and that young European Americans constantly traveled to the South Side to watch the African American musicians in hopes of learning to play. ${ }^{37}$ 
The dance halls, known as "black and tans" because of the racial mixing, presented a variety of social problems, according to the commission. They sold liquor, offered liquor as prizes, encouraged women to drink to excess, and kept windows closed to create a hot environment to encourage drinking. The customers expressed themselves with "coarse and vulgar dancing." All of this, according to the commissioners, made the clubs "highly dangerous to morals and established law and order, and a nuisance to the neighborhoods in which they are located." ${ }^{\prime 38}$ The commission was very clear that the public, and not the commissioners, saw the "black and tans" as dangerous because of racial mixing, rather than the sundry other activities that went on in the clubs.

The existence of the racial mixing in the "black and tan" cabarets, where musicians such as Louis Armstrong played, caused "frequent and heated protests," according to the commission. "Although mixed couples constitute somewhat less than io per cent of the patronage," the study reported, "this mingling is used" by critics "to characterize all of the association there." Both whites and Blacks frequented the clubs and the commission reported that members of these groups would leave their lo$\mathrm{cal}$ areas and travel throughout the city to visit the establishments. The public encouraged the police to arrest customers engaged in racial mixing. Unable to raid clubs to arrest interracial couples, because mixed couples were not breaking the law, the police used liquor violations instead to shut down the cabarets. ${ }^{39}$ When police raided the clubs, they arrested the mixed couples and allowed white-only groups to go free. The injustice of the arrests incensed African Americans in the city. ${ }^{40}$

White Chicago believed that African Americans condoned the racial mixing and eagerly accepted "vice" clubs in their neighborhoods. However, the commission study concluded that African Americans lived near vice districts not by "choice" or because of "low standards," as the Vice Commission had contended in I9II, but because of being unwelcome in the "white residence localities." The low-income levels among African Americans forced them, according to the commissioners, to seek out inexpensive housing that had been reduced in quality and price because of its proximity to vice. Contributing to this perceived problem was the insufficient political and social power held by African Americans, which left them unable to combat the "encroachments of vice" and the "gradual drift" of prostitution southward into the "black belt." Furthermore, the commission offered evidence that the proprietors of the brothels, cabarets, and gambling halls were not African American. The proprietors chose to 
live among African Americans, the commissioners argued, not because they believed this was the customer demographic; rather, the proprietors knew that living in the "black belt" provided protection from police and public authorities. ${ }^{41}$

The vice industry also took advantage of the reality of African American life in the city. Having been denied benefits by unions, victimized by the police, and crowded into unsuitable jobs and housing, African American men found that the one area where they were able to work freely was in the vice establishments. It was estimated in the I920s that I 2 percent of African American men ran bars, pool halls, and gambling rooms. The reason for the large number of African American-run venues of vice was that liquor and ice distributors were willing to front the money for the businesses. It was easy for the vice industry to bribe the city government for business licenses and protection from raids. Without equal treatment by unions or support from banks, the vice industry offered African American men the best chance at being entrepreneurs. Their businesses had a high rate of failure, contributing to family and economic issues in the larger community. ${ }^{42}$

African American women had fewer employment options than men. However, jobs in the vice industry were numerous. African American women could be found in the ladies' restrooms and dressing rooms in the cabarets and dance halls. The women paid a concession fee and were then permitted to sell necessities to women in the clubs. Club proprietors forced young white girls working as waitresses to "lure men." Fearful of the men, the young girls often fled into the dressing rooms. There, the African American women comforted the girls and explained the realities of life. Social workers portrayed the African American women as contributing to the downfall of the white girls, but there is another way of interpreting the situation: the African American women were telling the girls the truth about the life of poor women in Chicago. ${ }^{43}$

The social reformers who studied the links between African Americans and vice recognized the human disaster awaiting Chicago if action were not taken to alleviate the injustices of racial segregation; however, they were unable to escape believing the "social myth." Leaders in the social-reform movement attributed the behavior of African American patrons in the clubs to the fact that "all colored people are especially fond of music, but almost the only outlet the young people find for their musical facility is in the vaudeville shows, amusement parks, and inferior types of theatres." They were "pulled down," the reformers argued, by their "love 
of pleasure" and "drawn toward the vice districts, where alone the color line disappears." ${ }^{\prime 4}$ In these arguments, the reformers portrayed musical ability and participation in vice as being part of the same destructive urge and thereby naturalized the presence of African Americans in the clubs. In the end, the social workers had done case studies showing that African Americans were working in the vice district because of inescapable poverty; yet, the reformers still quoted from the Vice Commission's report, saying:

The history of the social evil in Chicago is intimately connected with the colored population. Invariably the larger vice districts have been created within or near the settlements of colored people. In the past history of the city, nearly every time a new vice district was created downtown or on the South Side the colored families within the district moved in just ahead of the prostitutes. ${ }^{45}$

Despite the insights and information the social reformers had, they were unable to see beyond the idea that vice and race were symbiotic partners. The adherence to the "social myth" was the pervasive problem for European Americans who wanted to help end the segregation of African American life in the city. It demonstrates how consequential the vice crusade was for African Americans in Chicago.

For the creative politician or policeman, it was not hard to benefitboth financially and politically_from the "social myth." The sometimes mayor, Bill Thompson, built his economic base on bribes from the Stroll's club owners. ${ }^{46}$ Thompson protected his power by instructing the police chief to ignore vice in the protected area, the Stroll. Then Thompson removed officers from the task force, fired the commissioner in charge of policing vice, and finally made sure that the City Council Finance Committee failed to appropriate money for anti-vice police measures. This led the state attorney in I9I9, after the mayoral election, to declare that the citywide vice resorts operated under the wing of certain city hall favorites. Through the efforts of someone connected with the city prosecutor's staff, numerous cases against gambling joint owners and operators of disorderly houses were dropped if the defendants were "in right" with the powers that be in their districts. ${ }^{47}$ Eventually, in the summer of 1928 , the Chicago Daily News and Herald Examiner exposed the operations of the political machine and reported that graft payments came from a wide variety of contributors-including 2,00o brothels, as well as crime 
bosses Al Capone and Jack Cusick, and beer "joint" owner Joe Saltis. The newspaper exposés did not disturb Thompson's system because it was a publicly recognized fact that politicians were indeed corrupt: Chicago remained "wide-open." 48

Though syndicate bosses did not have to fear city hall, the pressure from Prohibitionists did bring the federal police to Chicago in the I920s. They were more interested in the production and transportation of alcohol and less concerned with its distribution and consumption. Consequently, the resorts and clubs were able to exist because of federal indifference, local corruption, and the lengthy system of appeals. The legal limbo in which the clubs managed to exist would change in 1926 when a federal judge ruled that the Volstead Act applied to both places where alcohol was sold and to places where patrons provided their own liquor. A month later, twelve clubs had padlocked doors. In the raids that followed, the most prominent cabarets of the jazz era closed. ${ }^{49}$ Racial mixing and music performances continued on the South Side in the remaining venues. These clubs were smaller than the resorts and cabarets had been. The change in club size forced a reduction in the size of orchestras, which gave the small blues combos greater access to audiences. Prohibition would end in 1933, but the perception of African American music as the soundtrack of vice would continue in the imaginations of many Chicagoans.

\section{WHAT THE BLACK COMMUNITY LEADERS SAW}

The third force that shaped the musicians' experience was the response of the Black community leaders to the vice purge and the creation of the "social myth." In the eyes of the Black elites, the vice purge, the rants of the homeowners' associations, and the race riots were all ways that white Chicago reacted to the arrival of the African American migrants. This does not mean that the Black elites were eager to defend or support the recent migrants or their culture. On the contrary, the African American community's traditional leaders-churchmen, clubwomen, community organizers, newspaper editors, and intellectuals-saw the migrants' music culture as an accomplice to both urban and social decay.

The Black elites' discomfort with the new migrants shaped their descriptions of the Black migrant neighborhoods from the late I920s. These areas were noisy with life. The ice deliverymen and street vendors con- 
stantly sang to advertise their goods from early in the morning until night. From the tenement apartments could be heard laughter, Victrolas, radios, and the occasional piano. ${ }^{50}$ The elites feared that "gambling, bootleggers and what-not will take the neighborhood away from decent people, and run them out of their homes...." All of the music of daily life and of the illicit nighttime world were detriments, in the minds of the Black elites, to the "health" of the neighborhoods. ${ }^{51}$ The culture of the nighttime world was also, according to the Black elites, dragging down the public image of African Americans, which made the migrants a threat to the community the elites had created.

So strong was the association between vice and music that the Black migrant class and the working class found that they were unwelcome in established Black churches. For the musicians, the reaction of the Black church leadership was as damaging as being banned from the radio, because churches were central to the music culture of Chicago. In fact, the tension between the established African American middle class and the lower classes was so high that the Black elites attempted to close their churches to the migrants. Members of St. Thomas Episcopal Church actually vacated their building to avoid allowing the migrants to join their church, but the reordering of Chicago by the Great Migration was inescapable. ${ }^{52}$ The migrants (including the musicians) and their music cultures were going to change the city.

Beginning in the late nineteenth century, the Black elites had built a class-based pecking order in the African American community, which gave them both social and political control. The class structure rested on the notions of "refinement" and "respectability." Those at the top of the social structure maintained their positions not because of their wealth, but because of their membership in social institutions such as churches, the YMCA, and the Masonic lodge. These institutions became symbols of "refinement." In addition, the established community leaders were generally not new migrants, but rather came from the "old settler" class-a group of African Americans who had, or whose parents had, migrated to Chicago in the nineteenth century. ${ }^{53}$ The elites distanced themselves from the working class through social clubs, choral societies, and annual events such as formal balls, demonstrating that they were not opposed to music in general and saw certain types of music as a force for communitybuilding. However, to reinforce community standards the elites were using a different kind of music than the majority of new migrants used to build their community. 
The problem with music performances on the Stroll, as African American reformists saw it, was that they brought a white audience from throughout the city to the area and led to racial mixing in the music venues. Their reticence regarding the presence of whites on the Stroll was not an issue of racial hygiene, as it had been for European American reformers. Instead, they saw mixing as a corrosive force in the Black community because it introduced European American entrepreneurs, white patrons "slumming" in Black culture, and corrupt white politicians to the area. The Black elites blamed the presence of whites in the clubs, dance halls, and theaters for violence, police raids and brutality against African Americans, and the struggles of Black businesses. ${ }^{54}$ For example, clubs that had been the pride of the African American community in the early I920s, such as the Black-owned Pekin and the Dreamland, were closed by the end of the decade because of Prohibition violations. The African American leadership blamed white patrons and white investors for the downfall of the Black-owned venues. ${ }^{55}$

For the Black elites, the presence of white Chicagoans on the Stroll led to the slow erosion of their leadership role. ${ }^{56}$ After all, the Black elites had been powerless to stop the police and politicians from pushing the brothels, saloons, gambling halls, and dance halls into the Black neighborhoods following the vice crusade in I9I2. They could not prevent the police raids focused on mixed-race couples in which African Americans were arrested while whites went free. Similarly, the Black elites lacked the power to force the integration of the middle-class neighborhoods of Kenwood and Hyde Park in the r92os.

Black elites were unable to coordinate a strong opposition to white supremacy, the power of white business owners, and the corrupt white officials in the "black belt" until the r93os. At that time, they organized around the idea that African Americans were being cheated and discriminated against by white business owners, which was an argument rooted in the numerous court cases in the I920s that protested the treatment of African American patrons in theaters. ${ }^{57}$ Their boycott movement followed the advice of W.E.B. Du Bois, a founding member of the NAACP, who argued that a race consciousness could be formed around economic strategies. Drawing on this argument, the Black elites sponsored the "Don't Spend Your Money Where You Can't Work" campaign, which began in Chicago's Stroll area. Black leaders in the NAACP, the Black press, business leaders, and Black gambling concerns all united to bring more Black jobs and businesses to the South Side. The result was the creation of 2,000 
new jobs, such as bank and drugstore clerks, in the "black belt," and the campaign quickly spread to other cities. ${ }^{58}$ The presence of the Black gambling operators in the coalition of leaders suggests that if there was going to be vice on the Stroll, it would be Black-controlled vice. Similarly, the elites did not oppose the Black-owned clubs and theaters, because a Blackowned system would have expanded and buttressed their control of the area.

The second element of concern about the Stroll's culture was what the Black elites saw as the sordid and low behavior of the migrant class. The middle-class reform movement responded by attempting to force the migrants to adhere to middle-class behavior and values. ${ }^{59}$ This proved impossible despite leadership from the Urban League of Chicago, which, in the I920s, began a campaign to prevent the new migrants from drifting into the dance hall world of the Stroll. The League urged the migrants not to make themselves a "nuisance" and advised, "Don't congregate with crowds on the streets.... Don't encourage gamblers, disrespectable women or men to ply their business any time or place. . ." ${ }^{\prime 60}$

The Urban League's efforts to reform the migrants were part of a complex campaign to "uplift" Black culture and the Black working class. Black leaders recognized that whites intended that segregation would have to be both physical—such as in housing spaces, and cultural—such as in music. To that end, the segregationists turned their attention to the emerging importance of broadcast radio in the early I920s. The radio posed a threat to segregated Chicago because sound waves could cross the physical dividers of the city and create a new urban landscape in which African American culture could reach anyone anywhere. Not surprisingly, Chicago's radio industry grew in and around the debate between both white and Black urban reformers and entrepreneurs concerning the control of urban space. White middle-class stewards of Chicago led this uplift movement. They demanded radio educate the masses as to the values of Americanism, which did not include elements of Black culture. Broadcasters were willing to meet these demands because of the need for advertisers. The result was that all the announcers and radio performers, including orchestras, despite the fact no one could see them, were European American. The determination to segregate the airwaves demonstrated that civic leaders were aware that music could reaffirm or destabilize "community values." ${ }^{\prime \prime 1}$

Though African Americans were unable to acquire broadcasting licenses until I928, audiences did experience jazz and blues through late- 
night simulcasts from the "black belt" clubs. These broadcasts allowed the audience to listen to Black culture without having to travel to the "black belt" or understand the socioeconomic realities behind the music. However, in-studio performances of blues and jazz were by non-African American orchestras because sponsors preferred European American performers. Announcers were also European American. In addition, "blackface" broadcasts, such as Amos and Andy, were commonplace. ${ }^{62}$

Black middle-class leaders also regarded the emerging popular music as being a powerful tool in their "uplift" campaign. Central to this movement was the creation of the first radio program in Chicago hosted by an African American in 1928. WSBC's The Negro Hour, hosted by Jack L. Cooper, a syndicated journalist and editor of the Chicago Defender, which sponsored the broadcast, was an aural intervention into the representation of African Americans in the metropolis. Cooper became a hero for the Negro Civic League, which had pressured the radio station owner into creating a program by and for African Americans. By presenting a wide variety of performances, from church ministers, choirs, and the occasional jazz record, while providing a platform for community fundraising and public affairs, the program advanced the Black elites' middle-class agenda of reform and uplift. Cooper reached out to the new migrants by creating a missing-persons program that reunited families separated during migration. It is for this reason, and not the cultural elements of the broadcast, that The Negro Hour received support from the migrants and became the voice of the community. ${ }^{63}$

The "uplift" campaign reveals an important difference between this generation of elites and their parents. In the late nineteenth century, the Black middle class enthusiastically cultivated white clientele and patrons. In the I9Ios and I920s, the Black middle-class leaders began to form organizations that resisted white control, such as Black-owned newspapers like the Chicago Defender and the civil rights-focused Urban League. Like leaders of the Harlem community, ${ }^{64}$ they also created institutions that were African American branches of white-only organizations, such as the YMCA. The idea of separate institutions would have been abhorrent to nineteenth-century leaders. They would have seen the formation of such institutions as evidence that they supported segregation. But from the I9Ios through the I930s, as leaders such as Booker T. Washington and W.E.B. Du Bois argued, the establishment of Black organizations seemed essential to building the social infrastructure of the South Side. Those 
creating these organizations saw themselves as fighting against the white community's attempt to cast Blacks as the racial other incapable of selfrule by making a visible stand through the creation of institutions that had long been the hallmark of cultured communities in America. Those supporting these institutions saw themselves as opposing segregation and the racism that justified it by demonstrating the power and worth of the Black community. ${ }^{65}$

The "uplift" campaign, articulated by Cooper on the radio and propagated in the pages of the Chicago Defender, extended into the nightclubs. The promotion of "uplift" was in part due to the activism of Ida B. WellsBarnett. She represented the old guard of intellectual leaders and the "old settler" migrants in that her arrival in the city predated the mass migration of African Americans starting with World War I. In short, she was a member of the vanguard of post-Reconstruction intellectuals and advocates. In Chicago, she was a leader in the city's women's groups and in the NAACP's anti-lynching campaigns. When it came to music, she supported "culture," which she defined as being anything that improved the condition of African Americans in the city. She loathed vaudeville theaters, gambling halls, and saloons, as well as the entertainment found in these establishments. However, she was excited about the founding of the Pekin Theater. In it she found the realization of her dream of a theater in which African Americans could sit anywhere they desired, where the décor was tasteful, and where the performers and audience rivaled those in the palaces in the downtown area. ${ }^{66}$

Church leaders supported the Pekin at Wells-Barnett's cajoling. Reviewers heralded it as the "greatest sign of progress ... found among us." ${ }^{167}$ Eventually, the Pekin played a significant role in the elites' attempt to separate themselves publicly from the lower strata. Take, for example, the fact that the most prized seats in the audience, much like the most prized pews in the churches, were for sale at the high price of $\$ 2$ apiece. This price made "progress" and "uplift" the benevolent territory of the elite classes. Attending the Pekin was a demonstration of rank and social order that debased, rather than uplifted, the poor because at its center was the intentional erasure of the working class from public representation in the "black belt." The migrants were laborers and performers in these clubs. They served the elites, which strengthened the social hierarchy. The migrants and the elites may have enjoyed the same musicians, but the elite at the Pekin did so under the guise of propriety. ${ }^{68}$ 
The Pekin also represented the building of an autonomous Black cultural sphere on the South Side. Like the "Don't Buy" campaign and the effort to teach rules of propriety to the migrants, the Pekin disproved stereotypes of African Americans as lazy, artless, and inarticulate because the theater was an expression of the Black entrepreneurial spirit. It employed African Americans and provided a venue for performers as varied as opera singers and jazz musicians.

Promoting the Black-run venues were Black clubwomen, such as Wells-Barnett, who tirelessly worked to promote and arrange cultural events. As in Black communities throughout the United States, Black women were acting as brokers and activists, seizing on the politics of the Progressive era and remaking them despite the fact that they lacked political power and financial support. ${ }^{69}$ Middle-class women, dedicated to the idea of "uplift," started the first Black art museum in the nation and based it in Chicago. They created Black History Month, brought Black literature into school curricula, amassed a public-library collection dedicated to Black arts and letters, and forced white city officials, such as the superintendent of schools, to accept their programs. In addition, they transformed community centers, churches, public libraries, and, in later decades, housing projects into performance spaces for Pan-African intellectual endeavors. It was Black middle-class women who created the spaces where the Chicago Renaissance could flourish, and in so doing they created spaces where African American leaders could come together and build a community capable of resisting white oppression. ${ }^{70}$ The existence of so many Black venues encouraged more musicians to migrate to Chicago, feeding the city's cultural and intellectual renaissance.

So powerful was the cultural sphere that, by the r930s, Black Chicago was home to a growing group of literati. In part due to the work of these intellectuals, both the self-educated and those emerging from the University of Chicago, a view of the working classes as hopelessly mired in their social situation began to take the place of the optimistic idea that the lower classes could be uplifted. Black musicians increasingly were, in the minds of the leading Black authors and sociologists, purveyors of the folk culture that prevented African Americans from becoming modern men and women. In this emerging intellectual tradition, Black music became the metaphor for, as well as the cause of, what they perceived to be the "paradoxical cleavage" of migrants' daily lives: they worked all day in "one civilization" and then went home to the "black belts," 
where they lived "within the orbit of the surviving remnants of the culture of the South, our naïve, casual, verbal, fluid folk life." ${ }^{71}$ In this sense, the music, like the churches and burial societies, supposedly held the migrants back by tethering them to the past. These intellectuals argued that neither "hot music nor gospel hymns," neither "prayer nor rot gut," neither "jitterbugging nor shouting" could banish the "tormenting devils of poverty, ignorance, and racial discrimination." ${ }^{\prime 72}$ This critique offered little understanding of the place of music in African American life, how it was remaking Chicago, and how it challenged segregation. Instead, the intellectuals saw the migrants as standing at a "crossroads." Until that day when the migrants joined the progressive march forward, they would stand and watch the parade go by without understanding its significance. ${ }^{73}$

\section{WHAT THE MUSICIANS SAW}

Though most of the migrants were illiterate, they were neither as uneducated nor as unconscious as the scholars' and civic leaders' portrayals suggested. What the absence of literacy did was create an environment in which the scholars and civic leaders could discuss the migrants in terms of vice, "uplift," and the "social myth," but the migrants could not generally answer back. The migrant musicians were an exception to this rule of public discourse. In their music and in their professional organizations, they had a forum that other migrants lacked.

Where Chicago's Black elites had W.E.B. Du Bois's writings to guide their resistance movements, the musicians had composers such as R. Nathaniel Dett providing the philosophical foundation for their discourse. As a leader in the classical community and a transient figure in the Chicago Black music scene, Dett argued, in the early I90os, that the growth in the popularity of Black secular music among the European American audience was due in some degree to the popularity of minstrelsy-a form of music in which white performers mockingly pretended to be African Americans. He doubted that white audiences had ever considered the serious "utility" of Black music because of the "almost slavish devotion of the American composer and musician to European ideals and standards. ${ }^{\prime 74} \mathrm{He}$ could see the possibility of a growing appreciation of the "worth" of Black composers, but he also saw the African American com- 
munity as embarrassed by Black popular idioms because of the long tradition of white interest in minstrelsy. For Dett, the solution was clear: there had to be a movement actively engaged in the

emancipation of Negro music from the chains of false and often low ideals set upon it by popular minstrelsy, and in the establishment of it as a wonderful thing, a gift, an art, a glorious contribution to this nation and to the world, which though from a despised source, might yet be respected, used and even loved for its own sake. ${ }^{75}$

Black artists could only accomplish emancipation, Dett argued, if Black composers and performers reclaimed their music and took away the markets and public interest in minstrelsy. He demanded that musicians and composers dedicate themselves to dislodging the "disposition on the part of some of the current newspapers and magazines to credit the American Jew with being the originator of 'ragtime."

The emancipation of music required activism. Though Dett had articulated what needed to happen, he lacked the organizational skills to bring the movement into being. His fellow composer Clarence Cameron White attempted to bring Black music teachers throughout the United States together into a professional organization, but his efforts were interrupted by World War I. It was not until I9 I9, when Dett, White and fellow composers Florence Price joined a movement, led by composer and Chicago Defender music columnist Nora Holt, that the classical composers, music teachers, and singers were brought together to found the National Association of Negro Musicians (NANM). Like the "Don't Buy Where You Can't Shop" movement led by the African American middle class on the South Side during the I93os and the African American version of the YMCA founded in the I920s, NANM sought to create race consciousness through community building and organized resistance. Holt believed that if musicians were going to travel freely without harassment and work freely in any venue, they were going to have to work together toward those goals.

Specifically, Holt was interested in using NANM to create opportunities for Black musicians. Holt combined her demand for activism on the part of Black musicians with Dett's push for Black musicians to have a share in the profits of their music traditions, but they also wanted Black musicians to focus their innumerable talents toward creating operas, art songs, concertos, and suites. ${ }^{77}$ 
It is important to remember that, at the time, classical music was still popular and commercial. By focusing on this form of music, Holt, Dett, White, and Price were imagining broad market and intellectual opportunities for Black musicians-both male and female-but in so doing they neglected the importance of, and did not work to develop, the jazz and blues market. In choosing classical music, they did not intend to devalue blues and jazz. Rather, they wanted the traditional music of the Black community to be combined with and to transform the classical traditions. Dett and other African American composers saw great worth in traditional Black music because it presented a way of vitalizing classical music and building an art unique to the United States. In Dett's imagination, the secular and spiritual traditions were not an end. Instead, they were a beginning that, when combined with the expansive possibilities of classical training, afforded the opportunity to develop a music-based nationalism. Black music, according to Dett, was an innovation, "a new trend of thought, a new and indigenous art in this country."178 If African American musicians would compose in this way, as the leaders of NANM thought, then they would be creating an American music tradition that rivaled the European tradition, which was a stance that contrasted sharply with that held by leading Black elites and intellectuals. ${ }^{79}$

NANM held its first convention in the summer of I9I9 in Chicago as the city became a cauldron of racial violence. The historic riot disrupted the convention but did not stop it. NANM chose Chicago because its Black population, while smaller than New York's or Washington D.C.'s, seemed to have a higher proportion of musicians. The high quality of musicianship in both popular and classical venues, such as the Pekin, which had a stock company and staged Sacred Concerts, and the growing number of churches and choral groups, both secular and religious, were attractive to NANM. In addition, Chicago was the headquarters of the Chicago Defender, which boasted a national readership, and the Associated Negro Press was also in Chicago. However, the city's dedication to music education was the deciding factor. The Chicago Conservatory and the music schools at the University of Chicago all offered classical training to the African American community on the South Side. Holt chose Chicago as the home of the new organization because of the Black cultural sphere. By I929, NANM had seventy-eight locals. In only ten years, NANM had created a viable music community, centered in Chicago, dedicated to the improvement of Black education, combining the folk traditions of spirituals and jazz with classical traditions, and improving the conditions for 
traveling performers. All of this suggests that Chicago was having an arts renaissance that rivaled the developments in Harlem. ${ }^{80}$

The music teachers and classical composers who founded NANM were also central to founding the Black local of the American Federation of Musicians, ${ }^{81}$ which originated in 1902 but did not begin to grow significantly in membership until the I920s and I930s. Both NANM and Black Local 208 leaders were responding to white oppression: the union local formed after white musicians refused Black musicians membership in the city's existing local, while NANM formed to promote African American composers and performers, as well as to provide a platform for resistance against racial violence and discrimination in public accommodations. The two organizations complemented each other well. NANM promoted Black cultural achievements, while the union fought for Black jobs and worked to defend the South Side from the white local's leaders who were working to prevent Black musicians from playing throughout the rest of the city. These organizations reflected the experience of musicians in the I9Ios and I920s in that they both grew from the idea that African Americans could only depend on support and guidance from other African Americans. The development of these organizations went hand in hand with the wider Black community's efforts to build a separate cultural sphere on the South Side. Though they were motivated by many of the same ideas, events, and needs as the "uplift" campaigns, the union and NANM focused on defending the rights of Black musicians, the value of their music, and cultural and physical territory.

Though the classically trained musicians and the union organizers were successful in organizing and in articulating the needs of Black musicians, they were not representative of the majority of the musician community. Jazz musicians were the largest group of musicians migrating to Chicago in the r9ros and I920s. Due to economic shifts in agriculture in the Deep South, blues musicians began to arrive in larger numbers in the I930s and I940s. ${ }^{82}$ Moreover, the demands of the migrant audience for jazz and blues would overshadow the market for the classical performers. Nevertheless, these different groups of musicians and their audiences would exist together in Chicago's "black belt." They would have similar experiences with discrimination and segregation because in the racial system of the city, what mattered was not the genre of music but the physical appearance of the musician.

The majority of the jazz musicians entering the cultural discourse in Chicago in the I920s were from New Orleans. They left the South in part 
because the U.S. Navy had closed "Storyville" - the famed New Orleans red-light district-in I9I7. As the vice businesses migrated to Chicago, so did the musicians. Among this generation of musicians was trumpeter Louis Armstrong. ${ }^{83}$ Armstrong played in both the New Orleans and Chicago vice districts, and in his personal writings he noted that a stringent segregation governed the New Orleans music scene. The "Creole" musicians could work in "places with ease because of their light skins. Places we Dark skinned cats wouldn't dare peep in." Working in the New Orleans district meant acquiring permits, but Armstrong argued that it was worth the hassle because the area had the best jobs. Once in the clubs and cabarets, physical segregation was the rule, in that the musicians could not mix with the audiences. ${ }^{84}$

Chicago differed from New Orleans, according to Armstrong, because white musicians in the I920s played in the "black belt." "There weren't as many white bands as the Negro bands in the District, but the ones who played there sure was good," he wrote. As an example, Armstrong recalled visiting the Fiume, a "black and tan" where he saw an "all white" Dixieland combo play nightly. The presence of whites in Chicago's "black belt" music scene surprised Armstrong because he had never seen "such a beautiful picture before. I had just come up from the South, where there weren't anything as near beautiful. ..." In New Orleans, he had heard white musicians playing in the Mardi Gras parades, but he recalled, "I did not get to know any of the White Musicians personally, because New Orleans was so Disgustingly Segregated and Prejudiced at the time-it didn't even run across our minds." In Chicago, he counted himself fortunate for befriending such white musicians as Wingy Manone and the New Orleans Rhythm Kings. Armstrong even bought the white musicians' recordings and sat in with the Dukes of Dixieland in Chicago and New York. ${ }^{85}$

Eddie Condon's memoir supports Armstrong's view of the racial mixing in clubs and uses a similarly celebratory tone to describe it. Condon, himself European American, recalled there being "white boys" around the bandstand at the Dreamland and the Lincoln Gardens before Prohibition. He described the young men as learning to play from watching African American performances and listening to African American records. These young men were high-school students who transformed their school bands into jazz bands. "Jazz was not considered a proper profession for well-bred young white men," Condon wrote. In a sense, they were choosing to submerge themselves in the "black belt" and rebuking the European American culture of their Chicago suburbs. More than that, 
they were migrating across racial lines to learn music on the South Side because they were looking for themselves. Their relationship with the music was not much different from that of other musicians playing in Chicago in the late I9 Ios and early i92os.

Sidney Bechet, an African American saxophonist and clarinetist who migrated to Chicago with the first waves of New Orleans musicians, characterized the music as "a lost thing finding itself." Most articulately, he described the musician as a lost man, a stranger to himself, who crosses through the doorway and finds a home. ${ }^{86}$ For musicians like Bechet, making music was an act of migration, whether it was white youths traveling to the South Side, musicians sojourning from the southern United States, or a racially mixed couple moving across a dance floor. Each act of migration was a challenge to the accepted notions of racial propriety and notions of place because it entailed crossing racial boundaries.

Jazz bassist Milton Hinton painted a less rosy picture. Hinton, whose family migrated from Mississippi to Chicago beginning in the I9Ios, recalled the racial situation in the I920s and early i93os as one in which white musicians could travel anywhere in the city, but black musicians could not. The white musicians would visit the South Side and learn styles and techniques from watching and sitting in with the African American musicians. Then the white musicians would record what Hinton termed "a reasonable facsimile" of the music. Recording was not an option for many Black musicians. In this way, white musicians rose to prominence and made money. Hinton did not resent the white musicians because it was common for musicians to study together and learn from one another. Instead, he resented the "establishment" for limiting his career. ${ }^{87}$

Hinton went on to explain that the majority of Black musicians worked day jobs and non-union music jobs to feed their families and survive in a city that was at once a mecca for musicians and a destroyer of musicians. He was right. They worked in the steel mills, meatpacking plants, rail yards, and drug stores. Trumpeter William Samuels was an elevator operator and a mail carrier. Big Bill Broonzey, guitarist, was a Red Cap bag handler, and Doug Suggs, pianist, worked as a porter. It is not a surprise that musicians would struggle to make a living-historically, this was the reality for musicians in any era or city. ${ }^{88}$ However, the jobs they had were as much controlled by race as their work as musicians was.

Indeed, though in after-hours clubs and in an ever decreasing number of the legitimate venues outside of the South Side, musicians such as Armstrong, Bechet, and Hinton may have played with integrated groups 
and for integrated audiences, racial separation governed the other aspects of their lives and careers. Louis Armstrong, for example, met his greatest collaborator, pianist Earl Hines, in the Black musicians' union hall. When Hines and Armstrong began to record in the spring of 1927 and into I928, they did so with other Black musicians. Their record label, Okeh, by that time a subsidiary of Columbia Records, was a "race label," meaning it was white controlled and dedicated to recording Black music that would be sold almost exclusively in Black neighborhoods. Audiences and critics would eventually tout the songs that came from these first sessions, "West End Blues" among many others, as remaking American music. ${ }^{89}$ However, it should be remembered that the performers were members of a segregated union, played in illegal clubs, and recorded for a racist music industry that labeled their art "race music." It was a segregated America that was being remade.

What the jazz musicians could not see was that the racially mixed and lucrative world of the Stroll in the I920s and the early I930s was a dying world. Each police raid that arrested mixed couples and each club closure brought about by Prohibition violations fed cultural segregation in Chicago. When combined with the dehumanizing realities of substandard housing and the crushing physical stress of labor in the Chicago factories and meatpacking plants, the circumscription of African American lives was becoming seemingly inescapable. It is no wonder that the African American musicians who migrated to Chicago in the I940s found that Blacks in Chicago "weren't really free." ${ }^{\prime 90}$ All they had done by migrating was move from the "inhuman south to the more cleverly inhuman north."191 It was clear to African American musicians in the I940s that if they were to emancipate their music from the "social myth," as Nathaniel Dett demanded, then they were first going to have to emancipate themselves from the confines of the South Side and the city's racial system. 
CHAPTER 2

\section{From South to South Side Musicians in I940s Chicago}

In the early I940s, African American musicians arrived in

Chicago by train. They disembarked at the Illinois Central Railroad station on the edge of downtown and the South Side "black belt." In comparison to their homes in the southern United States, the speed of the city was shocking and they felt confused by the crowds of people. Just crossing the street would have been life threatening due to the velocity of taxis and trucks rounding street corners. If they arrived at night, the migrants first noticed the city's lights and the businesses that never seemed to close. If the migrants arrived during the day and it was summertime, the smell of the paper mills and the slaughterhouses was overwhelming.

For many of the musicians, Chicago was the only city in their minds. Throughout their lives they had been connected to Chicago through the railroad; the Caterpillar company, which made the farm equipment in use by the I940s; blues records that were pressed and recorded in the city; and the catalogues from Sears and Montgomery Ward, through which they bought their instruments. ${ }^{1}$ Between 1942 and I945, the U.S. Navy recruited over 5,000 Black musicians, from across the country, to play in military orchestras. All 5,000 were stationed at the Great Lakes Training Station and took their weekend leaves in Chicago. ${ }^{2}$ Other musicians were migrating to the city for wartime jobs. According to blues guitarist B. B. King, Black musicians felt that if they could save up enough money, then they could move to Chicago, where they might have a chance to make it as professional musicians. ${ }^{3}$ What the musicians, and other migrants, found upon arriving in Chicago was a landscape largely shaped by 
uniquely urban forms of segregation, which was evident the minute they arrived in the city.

One of these wartime migrants was guitarist and singer Muddy Waters. Stepping off the train in Chicago in I943, Waters felt as if he had entered a foreign country. "I wish you could've seen me," he told Rolling Stone magazine in I978. "I got off the train and it looked like this was the fastest place in the world: cabs dropping fares, horns blowing, the peoples walking so fast." "I had some people [in Chicago]," Waters explained, "but I didn't know where they was. I didn't know nothing." 5 "But I figured if anyone else was living in the city," he told Down Beat in I975, "I could make it there too." ${ }^{6}$ For example, he knew that musician Robert Nighthawk had left Mississippi for Chicago and had quickly cut a record. ${ }^{7}$ The presence of other musicians in the city made a difference to Waters. "If you don't know nobody, you're lost, you know," he explained. ${ }^{8}$

In coming to Chicago, Waters was seeking an established network of family from his home on the Stovall Plantation in Mississippi and of musicians who played music similar to his. It is not surprising that he knew people in the city or that he came to Chicago in part because he knew people there. By I930, there were 234,000 African Americans in Chicago. ${ }^{9}$ Due to a surge in migration during World War II, 20 percent of the southern-born population of African Americans was living outside the South by I950. Scholars of this issue have determined that these migrants were not only displaced farmers, like Muddy Waters, and industrial workers, but also urban, educated, and occupationally skilled men and women. ${ }^{10}$ The musicians reflected the diversity of the migration. While many were blues musicians from the rural South, there were also musicians from the southern cities, trained in classical and religious music, migrating to Chicago. The history of the musicians and segregation demonstrates that class, education level, and genre of music were to a point irrelevant in Chicago. The musicians were all subject to the same racial boundaries and laws of propriety_-such as segregated public schools, limited employment, and limited housing - as any other African American in wartime Chicago.

When the musicians arrived in the I940s, they found a city struggling to balance the tradition of municipal white supremacy and the demands for Black dignity and equality. Segregation in Chicago, as it was throughout much of the North, was a social reality enforced by violence, politics, market practices, and public policies. Though, unlike the South, it lacked whites-only signs over water fountains and was a place where Blacks were 
free to vote, Chicago in the I940s was a city where African Americans constantly pressed up against racial traditions. Wartime migrants to Chicago could expect substandard education and housing. They were given the worst and most dangerous jobs in the factories and slaughterhouses with no hope of ever being promoted. ${ }^{11}$ The only physical places the majority of whites and Blacks shared were buses, streetcars, and trains. ${ }^{12}$

To survive the various manifestations of segregation in the city, the musicians migrating to Chicago in the I940s had to form a community whose structure differed from what they had known in the South, and to draw on the strength of the existing musician community in the city. Many of the migrant musicians thought that the best way to accomplish this was by banding together in performances, establishing music programs in the public schools, and joining existing professional organizations like the National Association of Negro Musicians and the American Federation of Musicians union local. All of these activities added to the African American-led institutions that were the foundation of the Black cultural sphere on the South Side. Others in the migration survived the city by walking a thin line between being union members in good standing and questioning Black-led institutions. The migrant musicians' experiences in Chicago in the I930s and I940s reveal that the Black-led institutions were both sanctuaries from segregation and prisons built and maintained by segregation.

\section{CHICAGO-BOUND: MUSICIANS IN THE SOUTH}

For the rural musicians, there were numerous reasons to migrate to Chicago. The most obvious push factors were changes in the southern economy and the threat of racial violence. In the case of bootlegger and sharecropper Muddy Waters, who migrated to Chicago in 1943, the arrival of tractors in the Mississippi Delta created tension in his relationship with the white plantation owners. After several years of operating the tractor, Waters believed he deserved the same pay that the lead man received because they were both operating machines, which meant that Waters thought of himself as a skilled laborer. Waters asked for a raise, and in so doing entered into a conflict with the overseer. The overseer's anger surprised and frightened Waters. He knew that he would not be able to work on the plantation any longer.

The overseer was Ellis Rhett-whom Stovall residents remembered as 


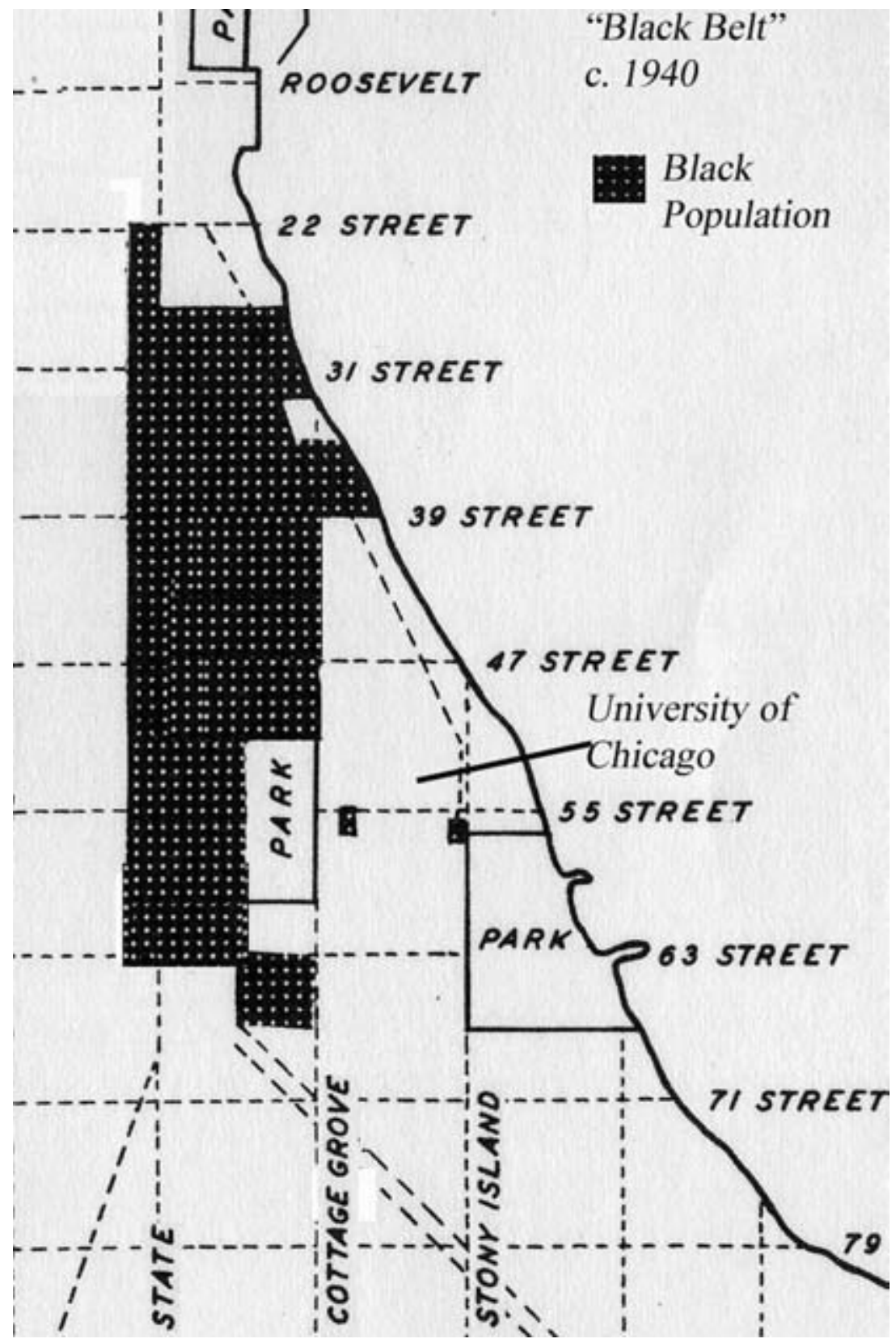

Map 5. This map demonstrates the "black belt" by I940. Based on maps created by the Social Science Research Committee at the University of Chicago, From the Map Library, Regenstein Library, University of Chicago. Created by the author. 
being "mean" and as "the kind of man that gave the South a bad name." The grandmother of Waters's wife warned Waters of the impending violence. She knew Rhett had once beaten a tenant with a horse bridle. She told Waters to leave to save his life. The promise of violence pushed him to abandon the plantation two days later, carrying one suit of clothing and a Sears Silvertone guitar. ${ }^{13}$

Statistics suggest that Waters was wise to leave the plantation. In Mississippi, it was not uncommon for lynchings to be announced in the local papers so that country folk would have time to come to town to watch the ritualized murder. The resulting scenes of bodies hanging from trees, which Billie Holiday gave voice to in the song "Strange Fruit," often were photographed and sold as commemorative postcards. Statistics indicate that between Reconstruction and the emergence of the modern civilrights era in the I950s, there were 539 African Americans lynched in Mississippi. Between I930 and I950, there were 33 lynchings reported in the state, more than in any other state. Furthermore, it is worth remembering that Waters's home on the Stovall Plantation was in the Mississippi Delta. This area became infamous in later decades for the lynchings of teenager Emmett Till in 1955 and civil-rights workers Andrew Goodman, Michael Schwerner, and James Chaney in 1964. No doubt the statistics and the media coverage of the violence underestimated the number of individuals killed. The threat of violence was enough of a reason for men like Waters to move. ${ }^{14}$

The fact that Waters took with him a Sears Silvertone guitar while fleeing the South is also worth noting. Most likely, it was the most expensive item he owned. In addition, it indicates that he saw himself as a musician and that he thought the guitar would be essential in Chicago.

The guitar method developed in the Delta distinguished the music of this area from that in other parts of the United States. The vital advance was the way the Delta players combined rhythmic elements with melodic slide techniques in their compositions. The existing recordings, such as "Preachin' the Blues," and documentary evidence attribute this change to Son House, who developed the style for which Robert Johnson and Muddy Waters became famous. These men-House, Johnson, and Waters-were the masters of the style because they could fret and slide the bottleneck in such a way that they gave the instrument speech-like inflections. ${ }^{15}$ These innovations made the guitar the essential instrument for this type of music. The guitar's portability also made it ideal for the migrant musician traveling to Chicago. 
Just as Waters's guitar came from Chicago, so too did most of the recorded music in the Mississippi Delta. Waters's own personal collection of recordings was an important link between Chicago and the South in that the majority of the records were recorded in Chicago. He owned records by Bill Monroe, the King of Bluegrass, and by the blues players who were remaking African American music at the time. The record collection suggests that Waters was not rooting his music only in the Black traditions of the South. Rather, he was listening to the cutting edge of white music and the musical transition between Delta blues and the electric blues from Chicago before he migrated there.

For example, one of Waters's favorite performers, Arthur Crudup, was a migrant from Mississippi who turned to playing music on the streets of Chicago because he could not find any other work. In I940, he began recording for RCA Victor's Bluebird label. His I94I recordings, which were part of Waters's record collection, featured an electric guitar. However, even after recording, Crudup continued to do menial work and farm labor in an attempt to earn enough money to return to Mississippi because he could not make a living from his music. It is doubtful that Crudup ever made more than ten dollars from his recordings, the amount paid to him at the recording sessions. Though Elvis Presley covered his songs, such as "That's All Right Mama," he never received any royalties.

Because it included Crudup's, Charley Patton's, and Bill Monroe's music, Waters's record collection is evidence of the transition in music and the transition of Waters into a man who could picture himself migrating to Chicago and becoming a professional musician. He noted that he learned to play his Sears guitar in part by listening to the Chicago recordings, which permitted him to build a persona-that of Muddy Waters the professional musician. When he listened to the Chicago recordings, he was listening to his future.

The changes solidifying in Waters's identity were part of a larger cultural movement in the Mississippi Delta under way at the time. The jukebox playlists in the public houses in Clarksdale, Mississippi, the largest town in the Delta, reflected this cultural shift. Artists on the jukeboxes included jazz greats like Louis Jordan, Earl Hines, Louis Armstrong, and Count Basie, all of whom were prominent in the Chicago scene. The jukeboxes recorded the number of requests made for each song, revealing that the top-two requests for I94I through I942 were for jazz musicians recording and working in Chicago at the time: Count Basie's "Going to Chicago" was number one and Louis Jordan's "Pine Top Boogie Woogie" was num- 
ber two. ${ }^{16}$ Other important Chicago artists, such as Memphis Minnie and Artie Shaw, also appeared on the jukebox lists. The jukebox songs suggest that Mississippi culture was far from isolated and that popular music recorded in Chicago was a prominent feature of the Delta soundscape. This is in part because Chicago was a geographic hub for recording and distribution, but it was also the city where African American artists recorded and the primary city in the minds of those thinking of migrating. ${ }^{17}$

The African American migrant community and the community in the South recognized the power of this music, as their choice to hide and suppress certain recordings reveals. For example, "Bilbo is Dead," released on Aristocrat (the original name of Chicago's independent recording company Chess) in 1947, celebrated the death of Mississippi Senator Theodore G. Bilbo by suggesting it was a great day for Blacks. ${ }^{18}$ Dozens of other songs protested racism, such as those concerning the Scottsboro Boys' trial, and lynchings, such as those chronicling the murder of Emmett Till. The political albums were not sold outside the Black community and were absent from the radio and jukeboxes because African Americans feared the racial violence that might follow the playing of the albums in public. ${ }^{19}$

A survey conducted in the Delta by Fisk University sociologists in the early I940s focused on the reasons that audiences chose certain songs. The survey asked the following questions: "What kind of music do you like best?" "What kind of songs do you know?" "What do you like to dance to?" "Who is your favorite musician?" And, "What is your favorite song?" The lists of favorite songs and artists compiled in the jukeboxes and in the survey reveal that many of the songs were recent releases. Among them were blues recordings by Lemon Jefferson, Memphis Minnie, and local Mississippi hero Charley Patton. Along with recordings by Gene Autry, Hank Williams, Count Basie, and Louis Jordan. The only two songs in the survey that mention a city in the title are "Sweet Home Chicago" and "Going to Chicago." 20

The survey revealed a racial pride among the audience. Repeatedly, in answering the survey questions, the informants kept insisting that they liked music by Black performers precisely because the artists were Black. The sociologists conducting the survey saw this as a sign of the rapid social changes occuring in the Delta, making the song preferences and lyrics a protest against the "bulwark of racial segregation." The informants were suggesting a growing race consciousness in the Delta because they identified certain music as "Negro music." One of the informants even went so far as to say, "Always will like Negro music, because that's my race 
and they can beat white singing any day." Another informant contended, "Negroes have a better voice for music. And too, they is my own color." ${ }^{21}$ African American musicians shared this belief. For example, Muddy Waters believed that he heard skin color. "I pictured so many people from the records. I knowed their color. I knowed their size. When I sees 'em, I was all disappointed. Charley Patton, he had that big voice. I thought the dude weighted two hundred fifty, you know, and he's big and black, much blacker'n I am. When I seen him, he was brown-skinned and neat. I said, 'It can't be.' He's a little man, pretty, yellow-skinned. Say, 'Hey, this man can't be doing this.' ${ }^{\prime \prime 22}$

What is apparent in the survey was that African Americans living in the Delta had a sense of their own importance, and the cultural importance of African Americans, in part because of the fame of musicians, which paralleled the growth of Black culture and consciousness then underway in the northern cities. African Americans in the Delta did not know the troubles of migrant artists such as Arthur Crudup. All the listeners knew was that he had moved to Chicago and recorded. The more the Mississippi audience participated in the Chicago/Delta cultural network, characterized by migration and the exchange of goods such as music, the more this racial pride and this vision of Chicago asserted themselves. The music from Chicago was a pull factor that made migration more likely, but it also increased feelings of self-worth and thereby increased the threat of racial violence.

\section{CHICAGO BREAKDOWN}

The southern wave of musicians-largely blues musicians-entered Chicago not as virtuosos, but as wartime workers during World War II. The Black migrants filled the warehouses, factories, and truck cabs by day, and at night they became musicians and audience members. For example, Muddy Waters arrived on a Saturday. By the following Monday he had a job in the Joanna Western Mills paper factory making cardboard boxes and loading forklifts. He started out on the swing shift. It was the first time in his life he had worked eight hours a day. Though he had spent his entire life working on a cotton plantation, he admitted that laboring in Chicago was "the heaviest jive you ever saw in your life." After a week, he had made nearly fifty dollars, which motivated him to take overtime. Working twelve hours a day, he brought home a hundred dollars a week. 
"Goodgodamighty, look at the money I got," he thought, or perhaps exclaimed. "I have picked that cotton all the year, chop cotton all year," he explained, "and I didn't draw a hundred dollars." ${ }^{23}$

Men like Waters did not always keep the factory jobs for long. "I got a job at the paper mill ... and then I got a little job workin' for a firm that made parts for radios." Eventually, he drove a moving truck and worked the numerous apartment evictions on the West and South Sides. This job provided the opportunity to acquire cheap furniture and to locate available apartments in the overcrowded city. ${ }^{24}$ Besides his day job, he worked seven nights a week playing at house parties, making five dollars a night. ${ }^{25}$

Other possibilities for the newly arrived musicians included playing on the street in the Maxwell Street Market District, a former Jewish neighborhood on the Near West Side. Guitar players in the Market District had to rent electric current from nearby apartments and run cords down to street level. The street, rather than the nightclub, became a classroom as the I940s generation of African American migrant musicians learned to play the electric blues by watching other musicians. ${ }^{26}$

Playing on the street was not a possibility in the Chicago winters. The primarily blues musicians took advantage of the cold weather by pragmatically expanding their cultural reach beyond the "black belt" and the small African American settlement on the Near West Side by playing on the city's trains and streetcars. ${ }^{27}$ Changing the location of Black music in the city took African American culture beyond the carefully constructed racial boundaries of the slum. Traditional music venues, such as nightclubs and symphony halls, had been segregated since the early twentieth century. Playing on the street and in the streetcars was a creative way of violating segregation standards by way of claiming new places for music.

The pragmatic attitude toward segregation, and toward the musicians' union regulations and traditions, was pervasive among blues and jazz musicians, who consistently breached the color line and appropriated space for Black music. Playing on Maxwell Street, which led to living around the market area, thus expanding the "black belt" outside of the South Side, and the routine of playing while riding public transportation when the weather turned bad were only part of the schemes and strategies the musicians developed. They also practiced the art of "scabbing"-playing non-union jobs-by showing up at a bar and requesting permission to play a few songs. Scabbing challenged the physical boundaries of the Black cultural influence by contesting white-controlled space in the city, as well 
as the control of the segregated music union over the musicians' professional lives.

Jimmy Rogers, who played harmonica and guitar with Muddy Waters, learned "scabbing" from Johnny "Daddy Stovepipe" Watson. Rogers recalled:

During the time I was living on Lake Street-I752 West Lake Streetand Stovepipe he knew the city just like a book, you know-all on the South Side, West Side, North Side-all over so I would follow him around-we'd call it scabbin-you know. You hit here, you just set up with asking this guy that owns the club if he wouldn't mind you playing a few numbers-quite naturally it was good for business, he would say okay. You'd play a number or two, they'd like it-you'd pick up a buck here, a buck there, you know. One club was 708 E. 47 th Street-we'd play there during the time I was scabbin. ${ }^{28}$

Men like these had to play house parties and on the street because segregation in the music venues resulted in an insufficient number of jobs, and because of great competition between Black musicians for union work in the clubs that contracted with Black performers. ${ }^{29}$

Further complicating the migrants' ability to make a living from music in the early I940s was the American Federation of Musicians union's ban on new recordings. The ban was due to the rationing of acetate and the controversy over royalties, and lasted from August 1942 through November I944. This made for an active club circuit for the well-known recording stars, but not for the newly arrived musicians from the South, whom the audiences had never heard before. ${ }^{30}$ Performers such as Bill Broonzy, Tampa Red, and Memphis Minnie held recording contracts, which gave them the lion's share of live gigs in Chicago's Black music venues.

For Black women, public performance was a slightly different situation than it was for the men. There were women performing in the clubs, such as Memphis Minnie, who was one of the first musicians to adapt the electric guitar to blues, and jazz trumpeter Dolly Jones, who regularly bested male musicians in "cutting contests." 31 Sister Rosetta Tharp paralleled Memphis Minnie by introducing electric guitar to gospel music. ${ }^{32}$ In addition, women were the majority of accompanists in the Black churches, as well as the majority of attendees at the churches. ${ }^{33}$ For many female musicians, however, public performance was impossible. It was 
not considered appropriate for women to perform in public. For example, Estelle "Mama" Yancey did not begin performing regularly in public until she was in her seventies. Both her father and later her husband, famed boogie-woogie pianist Jimmy Yancey, forbade her from performing outside the home. ${ }^{34}$

The difficulties of employment for African American musicians differed greatly from those of European American musicians in Chicago during the late I930s. Many of the white musicians felt a deep sense of angst in balancing their need to make a living with their need to be artists. These men tied their status as musicians to their craftsmanship and not their commercial abilities. For example, one man explained what it took to be commercially successful.

How do you get ahead in this business? Well, you don't have to play very well. All you have to do is be willing to be commercial. Know all the old songs and just stick to the melody and play with a corny tune. ${ }^{35}$

Another saw extensive contact with the audience as a detriment to the development of artistry because the musicians had to not just play but entertain saying:

we do an imitation of Rube Goldberg, that guy in the comics. We all stand in a line and I goose the guy in front of me, he breaks a phonograph record over the next guy's head, and that guy squirts the leader with a seltzer bottle. Sounds disgusting, doesn't it? ? $^{36}$

The worst job, from the European American perspective, was "strolling."

We stroll, you know, walk from table to table and "play your favorite tune." There's nothing lower than strolling. That's as bad as you can get. They tell me it was all the rage during the 'twenties. Man, it's horrible. Of course it pays like crazy, but it sure is a drag. ${ }^{37}$

Black musicians, on the other hand, rarely expressed being unfulfilled as artists because they had found work. Nor did they protest against close proximity to the audiences on the street corners. This leaves open the possibility the Black musicians were able to fulfill their artistic ambitions while working, or else the struggle to make a living was all encompassing, making their goals center on finding work rather than on being art- 
ists. After all, playing in a "strolling" band or a comedy band meant that the European Americans were working and not playing on the streets or begging for work as in "scabbing." White musicians only reported being unemployed as a result of a conflict with the musicians' union or as a result of moving to Chicago and having to wait out the standard six months before the union would allow them to work as musicians.

The differences between Chicago's white and Black musicians went beyond work patterns. The impact of segregation also manifested itself in health disparities. There appears to have been no large difference in the primary causes of death for white and African American musicians. The top three causes of death were virtually the same for both groups: heart disease, cancer, and pneumonia. However, African American musicians were on average more than six times more likely to die from violent death than white musicians. ${ }^{38}$ In addition, Black musicians were more than three times more likely to die from tuberculosis or a rheumatic heart condition than white musicians. ${ }^{39}$ Within the musician population, although relatively small, ${ }^{40}$ the higher rates of tuberculosis, rheumatic heart disease, and violent death among African American musicians suggests the power of poverty and segregation in Chicago. Each of these causes of death can be directly linked to inadequate housing, diet, and medical care indicative of individuals living at the bottom of a social structure. These conditions may have originated in the South, but segregation in the city did not help. Rather, the city ensured poor living conditions, and segregation in the union meant fewer and lower-paying jobs for African American musicians. The interaction between the social structure and the opportunity structure contributed to African American musicians' living, on average, twelve years less than the average white musician. ${ }^{41}$ What can be surmised from the comparison of the Black and the white musicians is that there were two Chicagos. This is not a surprise, but it does illustrate that race was a critical factor in terms of the Black musicians' experience.

\section{BECOMING A PROFESSIONAL MUSICIAN:}

\section{LIFE IN THE SEGREGATED UNION}

The musicians migrating to Chicago in the I940s found that the musicians' union played an important part in maintaining the differences between the white musicians and the Black musicians. In I902, Black musicians in Chicago, hoping to secure pay and job security, petitioned 
to join the American Federation of Musicians. The city's white musicians refused to allow Black members in their local, but did permit the Black musicians to form their own local.

The formation of the Black local reflected the political atmosphere in which it was born. In the first decades of the twentieth century, it was common for African Americans in Chicago to be refused membership and services throughout the city. Whereas in the nineteenth century, Black community leaders refused to form autonomous institutions for fear of endorsing segregation, Black leaders in the early twentieth century purposely built autonomous institutions as a way of resisting segregation through the establishment of race consciousness. ${ }^{42}$ The rejection by the white local may seem to have forced them to form the Black local. Yet, they did have a choice. They could have formed a local that was dependent on the white local. Instead, they demanded a local with the same rights as the white local, suggesting that they were attempting to take control of their situation through organizing and defense.

Even though the union bylaws gave the two locals equal access to the city, a system of segregation, similar to those in other music union towns like Los Angeles, ${ }^{43}$ emerged. White musicians dominated the North Side, the symphony, and the radio stations, while the Black musicians held the South Side, and initially, Black musicians embraced their separate sphere of influence because the South Side had more clubs than the North Side and because they did not anticipate that radio and recorded music would change the place of music in the city. ${ }^{44}$

The origins of separate locals are not complex: they existed at the request of the White local. The Federation did not issue a charter for a Black local unless the White local demanded it. By the I940s, there were 723 American Federation of Musicians locals throughout the United States and Canada, of which 36 were "colored" locals, meaning that in 36 areas there were two locals. Adding to the confusion over the status of Black musicians was the existence of Black subsidiary locals, mostly in the southern states, that worked under union bylaws but were given no representation in the union. Segregation extended to union branches without a Black local in that they did not allow Black members to enter the union halls. Instead, Black members had to go around to the back of the building to pay their union dues. The inequality in the union left the African American musicians in Chicago, according to Music Master, the Black local's publication, with few choices if they wanted to work and receive labor protections. "Organized labor can do much to alleviate this 
deplorable condition, by accepting the Negro in their respective unions as American citizens instead of accepting them on a subsidiary basis, or by granting them separate charters," Music Master argued. "A Negro will never prove himself a good unionist until he is given an opportunity to be one." 45

The presence of segregation in the union was never so blatant as it was in the union's national conventions. The first national convention that Chicago's Black Local 208 attended was in 1938 in Tampa, Florida. The hosting white union branch would not give members of Local 208 credentials to enter the hall, so Local 208 had to turn to the Urban League for help. The segregation of the convention extended out into the city of Tampa in that the musicians found that they could not go into downtown Tampa after dark. ${ }^{46}$ The treatment that the members of Local 208 experienced in Tampa was standard at every convention they attended because the conventions were always held in southern cities. Convention discrimination seemed most aggravating during World War II. Music Master noted that at the I942 convention, whose theme was democracy, the convention venue would not permit African American delegates to enter unless they were escorted by a white union delegate. ${ }^{47}$ Furthermore, there were times when the African American delegates could not stay in the same city as the convention because of the lack of a Black district. Cabs would not pick them up, bellboys ordered them around, and Local 208 men often found it difficult to buy food in the convention cities. The union did nothing to help. These kinds of conditions persisted until I964 and the passage of the Civil Rights Act. ${ }^{48}$

One consequence of having separate locals was the birth of a white leadership that derived its power from segregation. James "Caesar" Petrillo, president of Chicago's white Local ıo, embodied this leadership. In I93 I, leaders from Local 208 went head to head with Petrillo when they demanded that the locals merge. Local 208 leaders drew up a merger plan, but after four hours of discussion and debate, Petrillo indicated that Local Io would have to give the topic further consideration. A month later, the board of Local ro met and promptly vetoed the merger, saying that it "did not react to the best interest of either organization, and that Local no. 208 be informed of this fact, as it is felt that the present arrangement of the two separate organizations, having proven itself satisfactory over a period of years, be continued." ${ }^{49}$ The failure of the Black demand for a merger demonstrated Petrillo's position and was a harbinger of things to come.

Petrillo was confident in his ability to maintain segregation, and the 
threats by Black musicians to organize against him meant nothing. Petrillo's sense of security came from years of watching as rival union movements failed, which only strengthened his position in the AFM. He took control of the union local in 1922 and steadily increased its membership. Before the I930s, Chicago had four primary musicians' protective organizations. Three of them were for European ethnics and the fourth was for Black musicians. In 1937, Petrillo succeeded in bringing into the American Federation of Musicians of the competing organizations-such as the Polish American Musicians' union and the American Musicians' union. Petrillo was able to pull off this coup by offering the competing organizations full membership in his local without charging them an initiation fee. Thereby, he was able to destroy his competition, increase membership in his local, and prove his power as a labor organizer. As a bonus, he ensured that his local would not have to pay out death benefits to the new recruits..$^{50}$ Unbeknownst to the new members, they would not receive a death benefit, according to the bylaws of the union, without paying the initiation fee. This was a piece of information that their families discovered only at the time of the members' deaths. Furthermore, in the I950s, when greater numbers of Hispanics and Filipinos moved to Chicago, Local Io took them in as white members. ${ }^{51}$

The absorbing of the various European ethnics, Hispanics, and Filipinos placed Petrillo, who was the son of Italian immigrants raised in poverty on the West Side of Chicago, in a position in which he decided who was white and deserving of the privileges of that social status within the musician community. Petrillo's definition of white depended on maintaining the perception that there was a difference between the white musician and the African American musician. Petrillo never brought in the Black musicians, which was economically devastating to them in the I930s due to the changes occurring in the industry, such as the growing presence of mechanically reproduced music played in bars and the slow disappearance of many Black-owned venues. ${ }^{52}$

As the president of Local Io, Petrillo was as bad as any other local leader concerning segregation. If Black musicians tried to find a job in a white union club, Petrillo would threaten the club owner and send in "goons" to destroy the venue. Also, if the Black local attempted to picket a venue, Petrillo used his contacts within the electricians' union, the actors' union, and the stagehands' union to prevent them from supporting the Black local. ${ }^{53}$ When he campaigned to be the federation's national president, he tried to appeal to the Black vote by offering concessions. 
As federation president, he appointed Black members to the union committees and tried to prevent African American members throughout the United States from suffering the humiliation of having to go to union halls' back doors to pay dues. ${ }^{54}$ In regard to the remainder of the segregation rituals, he was silent, suggesting that he only made concessions when it would win him votes.

Petrillo's presidency of the federation coincided with key changes in the music industry-namely, the commercial use of recorded music replacing the live musician in the music venue. So stringent and total was his domination of the industry in the early I940s that Petrillo easily used strikes as a tool to prevent the broadcasting of copyrighted material until musicians received royalties and guarantees of jobs. Specifically, Petrillo fought for live musician jobs by insisting that radio stations only allow a union musician member to flip the records: these men became known as "pan-cake flippers." At amateur shows, whether on the radio or not, Petrillo demanded that a number of union musicians equivalent to the number of amateurs be employed despite the fact that the union members would not be performing. He applied the same standards to the legitimate theater. However, all of these new jobs were open to white musicians only. ${ }^{55}$ As it turned out, "Caesar" was an excellent name for Petrillo. He was an "autocrat," as American Mercury argued, ${ }^{56}$ but by demanding that musicians be paid for their music, he was also improving an industry that once paid musicians in liquor rather than in cash.

Petrillo's maintenance of, and in some cases authorship of, union segregation, contributed to the rise of a specific form of Black union and community leadership that built up the Black local as a way to counter segregation. In reinforcing the development of the autonomous Black cultural sphere on the South Side, Black union leaders believed that the community could draw strength from creating a separate sphere of influence-in the nightclubs, in the union, and in the schools. Though the South Side was a place defined by segregation, Black union leaders and music educators imagined that a distinct Black identity and culture could be formed there in opposition to the segregationists' idea of African Americans. They believed that it was possible to form this identity of opposition because whites did not internally control the South Side. ${ }^{57}$

Walter Dyett—bandleader, music educator, and union man-came to epitomize Black union leadership. Dyett was born in Missouri in I9OI and moved to Chicago in I92 I after completing his military service. In I93I, he began his career as the music teacher at Chicago's Black high 
schools, Wendell Phillips and DuSable. Training with Dyett was considered a "tradition" in the Black community ${ }^{58}$ Dyett taught a generation of musicians in Chicago, many of whom were the children of southern migrants. He could count among his students many of the city's most famous performers-including Nat "King" Cole, Benny Green, John Gilmore, Johnny Hartman, and Dinah Washington. So strong were the community ties created by Dyett that when musicians moved to New York City, they often continued to live and work with Chicago musicians with whom they had gone to school. ${ }^{59}$

The presence of the music program at DuSable High School was historically significant because it provided a foundation for the formation of a second generation of African American musicians in Chicago. ${ }^{60}$ It also made jazz into an academic pursuit as serious as European-based orchestral and band music. Its place in the curriculum combated the idea that jazz was a music based on emotion rather than study. Dyett's efforts continued the process by which Black folk music changed from an essentially oral tradition to a written tradition communicated and learned in an academic environment. This was a tremendous development in the course of African American history and it occurred in a Black public school.

Dyett brought his belief in the need for professionalization among Black musicians to the Black union local's board of directors, on which he served from 1945 to $1965 .{ }^{61} \mathrm{He}$ also brought to the union board a strong belief that, though integration with full equality and protections from discrimination was ideal, it would be impossible for Black musicians to live and work equally in a union led by whites. This belief was born of a lifetime of experience with racism-including service in the segregated U.S. military during World War I, a career in the segregated public schools, and life in the segregated music union - that was proof to Dyett that only a Black musician would protect the rights of other Black musicians. In a system dominated by whites, integration, Dyett feared, would be a new form of oppression in which the Black musicians would lose their cultural distinctiveness and the safeguard of the Black public sphere, which included an apartment building that only rented to musicians, a credit union, and rehearsal space all owned and managed by the Black local. ${ }^{62}$ Dyett believed in autonomy as a way to oppose and condemn segregation, but the growth in power of the Black local may have had an unintended consequence in that it provided Petrillo with the room to argue that segregation was "entirely satisfactory to the colored membership." ${ }^{163}$

In fact, the Black local's rank and file were well aware of the union's 
relationship to segregation. The membership passed around rumors that Petrillo had made a contract with the crime syndicates ${ }^{64}$ and that the Black leaders had orchestrated a secret agreement with Petrillo to maintain segregation. ${ }^{65}$ These rumors reduced Petrillo's legitimacy as a labor leader. As for the Black leaders, the rumors suggest that the Black musicians thought of their leaders as benefiting from and complicit in segregation. Jazz bassist Milton Hinton summed up the situation by contending that the Black leaders were to blame for segregation, saying that back in the I9IOs and I920s they had "wanted to maintain a separateness between black and white musicians, because of the fact that on the South Side, which was black territory, this is where it was most lucrative and where the money was made." ${ }^{\prime \prime 6}$ The prosperity of the South Side continued, Hinton contended, until large hotels, such as the Congress Hotel, were built in the downtown area and radio emerged as the music medium. ${ }^{67}$ The white local dominated the new medium and the downtown area and defended it as fervently as the Black local had defended the South Side, Hinton argued. ${ }^{68}$

Working in a union defined by the two contrasting beliefs represented by Petrillo and Dyett was a difficult reality for the Black musicians. On the one hand, they had to be members to work in legitimate venues, such as nightclubs. The union locals guaranteed a pay scale, regulated the workweek, and provided death benefits. Membership in the union also, at times, seemed to maintain rather than challenge the city's segregation. The result was a situation in which Black musicians belonged to the union as a way of negotiating the segregated city while simultaneously undermining the union by playing on the street, on the city's trains, and by scabbing. Many of them were friends with white musicians-with whom they may have played with in their homes, in the city's music schools, and at times in the illegal after-hours clubs, though they did not share a union. The economic segregation forced musicians, Hinton recalled, to break union rules by playing beyond the territory of the union. The musicians had to make a living, which necessitated that they load up the car and seek out venues along the highways where there was no pay scale or union rules. They would walk into an establishment and start playing. If they did not make much money, they would leave and drive further down the road. "We were hungry you know," Hinton explained, "and our families needed to be fed. . .." 69

The response of the Black membership to segregation demonstrated that the complexities of segregation required an equally complex system 
of resistance. For the most part, as long as there were ample jobs on the South Side, there were few organized protests against the white union leadership. Unfortunately, the lucrative South Side music culture would not last forever.

\section{VENUES}

On the surface, the division of the city into a white area and a Black area may seem imprecise and abstract, but union history demonstrates that it was in fact purposeful and political. ${ }^{70}$ The lines of division followed the segregation in housing, public spaces, hotels, and theaters throughout the city. In choosing to defend Black spaces in the city, the Black union leaders were appropriating space that had been defined by segregation in the hopes of transforming the designated Black areas into a representation of racial pride. In Black music, the Black union leaders saw a tool that promised to subvert the intentions of segregationists to stifle Black culture. The Black union leaders' choice reflected the mood of the entire Black community in the early twentieth century. Faced with growing racial oppression and the subsequent economic difficulties caused by racial circumscription, Black leaders developed a philosophy of self-help and self-sufficiency. ${ }^{71}$

The Black musicians supported the division of the city by belonging to the union, but they also subverted the power of the union by scabbing, playing in house parties, and playing on the streets. The result was a complex system of venue. Some of which were legitimate-such as nightclubs, that functioned within the union system, and some illegitimatesuch as the streetcars or bars that accepted "scabbing," that functioned outside of the union. The system of venues became representative of both the landscape of the Black public sphere, the diverse ways in which musicians lived, negotiated, and resisted segregation.

In the I940s, there were few legitimate union venues for the classically trained Black musician. Basically, it came down to playing at various South Side high schools and churches. Few venues spoke to the role of segregation in shaping the Black public sphere, as well as the churches and schools on the South Side. Segregation in Chicago's schools began just before World War I and became the norm during the I920s. ${ }^{72}$ The migrants had brought Black religious institutions, which began in 1816 when the African Methodist Episcopal church split from the main denomination 
over racial issues, with them to Chicago in the late nineteenth century. ${ }^{73}$ From the beginning, the Black churches and schools in Chicago were founded on the idea of self-help and stood against the aggression of white institutions. ${ }^{74}$ When there were no venues for Black classical musicians outside of the Black Belt, the churches and the schools provided performance space just as they provided social services for the Black community that the city did not. The existence of the community institutions indicates that African Americans had developed a pattern of behavior that confronted the problems of the urban environment through communitydriven programs and by appropriating space for the purpose of resisting segregation. ${ }^{75}$

Poro's Beauty College, located at 44I4 S. Parkway, was also a site of classical music. The city's Black opera company rehearsed there. Unlike the churches and the schools, beauty parlors and salons were not forced on the Black community by institutional segregation. Instead, they represented the growth of Black entrepreneurial enterprises in Chicago that focused on the specific needs of African Americans. For Black women, the salons were a place safe from the interference of white Chicago and as such became a site of what novelist Ralph Ellison termed the "unrecorded history" of African American culture and resistance. At Poro's, the operas and the hairstyling were both ways in which African American women could rehearse their challenge to white dominated concepts of class and beauty. In these rehearsals, they could act out Chicago leader Ida B. WellsBarnett's argument that African Americans represented the highest level of civilization and white Americans were the lowest form of civilization. The combination of the beauty college and the Black opera speaks to the manner in which African Americans used space in the "black belt" to redefine Black aesthetics and culture. ${ }^{76}$

The community felt encouraged when Caterina Jarboro played the title role in Aida in a Chicago Opera performance at the New York Hippodrome in I93 I because it was the first time a Black woman appeared in a leading role with a major American opera company. Shortly thereafter, soprano Camilla Williams won the title role in Madame Butterfly. The pride felt for the singers was similar to that expressed when the Rochester Philharmonic performed William Grant Still's Afro-American Symphony in I93 I and when the Chicago Symphony performed Florence Price's Symphony in E Minor at the Chicago World Fair's in $1933 .{ }^{77}$

Yet, by the I940s, it seemed as though the triumphs of the classical performers had changed little in terms of recognition and treatment of 
African Americans. Classical musicians sought to fight against the segregation of the city by turning to their professional organizations, such as the National Negro Opera Company, which staged a production of Verdi's La Traviata in the outdoor amphitheater located on the Potomac River behind the Lincoln Memorial in Washington, D.C. The National Negro Opera Company was conceived in I94I as an opportunity for "ethnic groups" to create "operatic compositions, using the cultural background of Negro Spirituals and Creole folk songs as the motif." Nonetheless, for the majority of classically trained musicians, these kinds of events were not the norm. By the mid-I940s, it was rare to attend a public performance of African American classical musicians even within the South Side. It was even harder to assemble an African American company. One conductor noted, "It was not even possible to find the first violin section among the Negroes in America." The problem was not a lack of trained musicians; rather, the difficulty lay in the fact that musicians had to work several jobs at once to make a living and were not able to focus on developing technique. The musicians were forced to work more than one job because of the lack of support for symphonies. "We have sufficient instrumentalists all over the country," wrote one reporter, "some in the jazz world," demonstrating that the musicians readily crossed genre lines to find work, "who would give their eye-teeth to join a symphony organization-if they were assured living wages along with their allegiance to the higher form of music. Where are our civic minded gentry, eager to uphold the tradition of the race as capable of filling the highest niches-in citizenship, religion, arts and science?"78 Though there were hundreds of African Americans in Chicago who were classically trained, they had too few opportunities to perform because of the segregated union and the daily reality of segregation in the city which limited both employment and venues. ${ }^{79}$

In contrast, there were numerous union venues for blues and jazz music, which often were filled by musicians with classical training. ${ }^{80}$ The posh clubs, such as the Rhumboogie, El Grotto, and Club Trianon, had been in operation since the I920s and were well-known throughout the city. Upscale clubs shared the South Side with seedy bars known as "joints." The South Side music area that spread out east from State Street was infamous for "Saturday night tavern brawls, Sunday morning visits to the Provident Hospital emergency room and Monday morning appearances in the Fifth District Police Court at 48th and Wabash." The favorite "joint" among blues and jazz musicians in the I930s and I940s was 


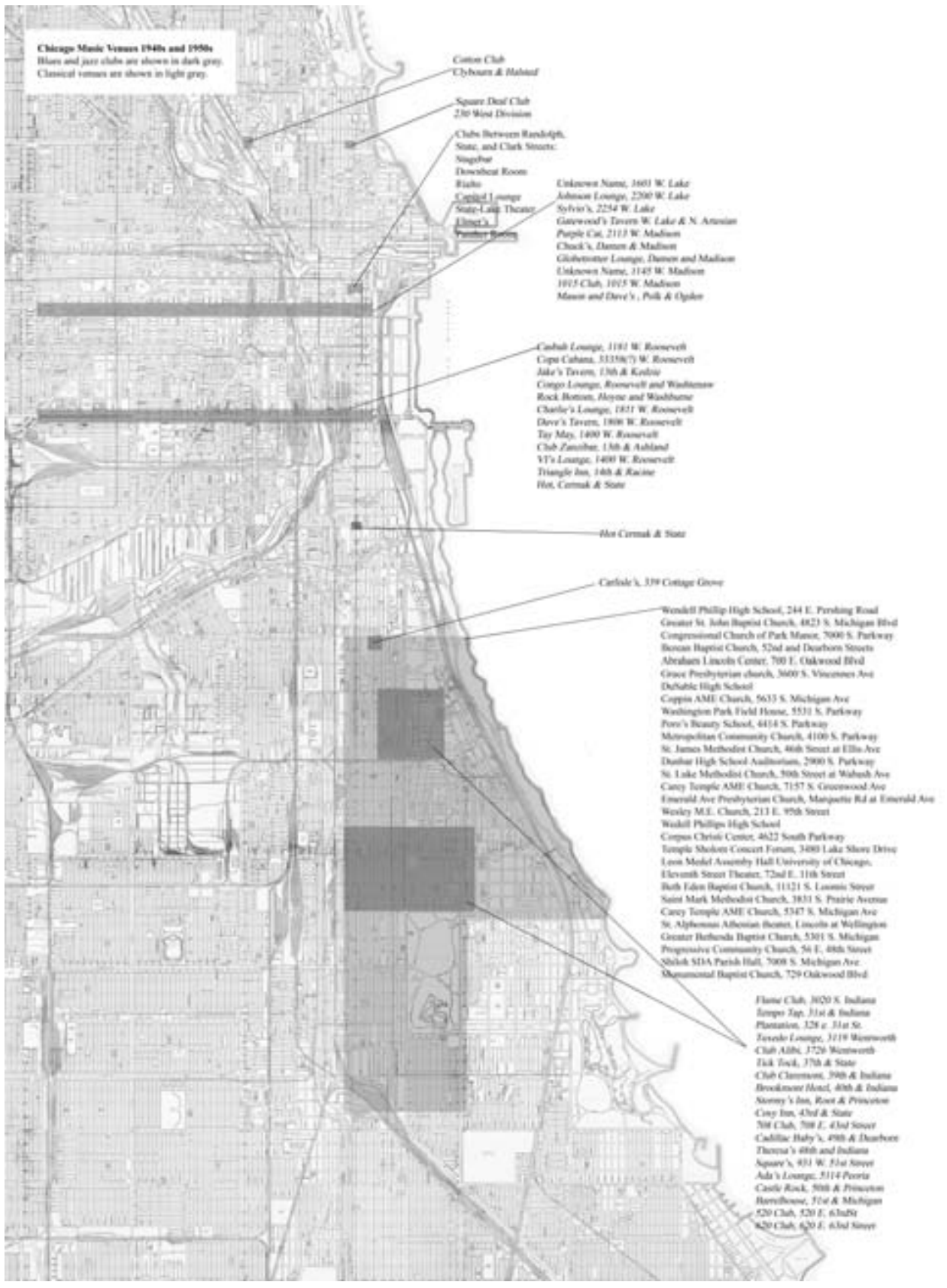

Map 6. Venues. Based on the ephemera and manuscript collections of the Center for Black Music Research, Columbia College, Chicago. Created by the author. 


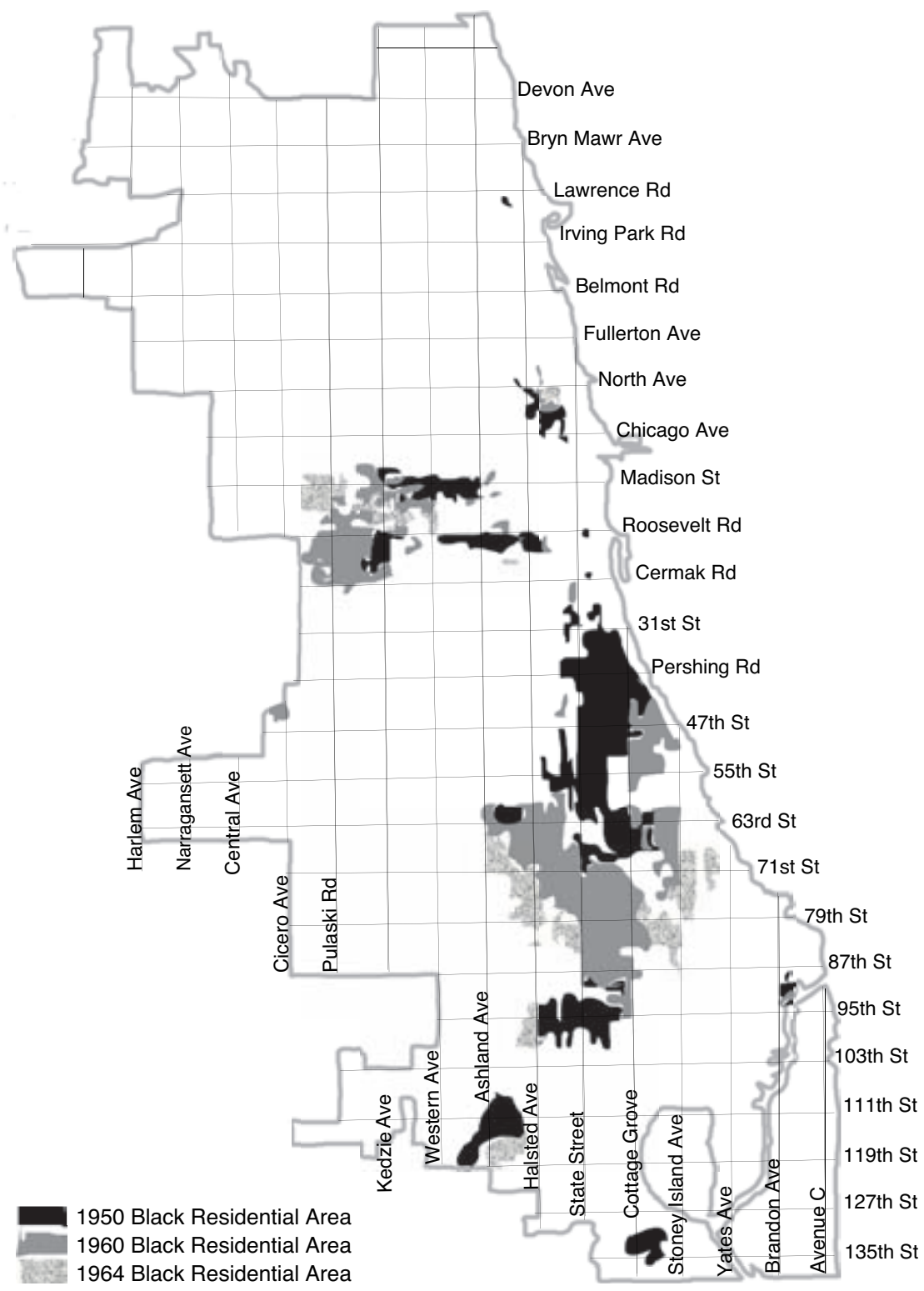

Map 7. Based on The Urban League's "Negro Residential Areas" from the Map Library, Regenstein Library, at the University of Chicago. Created by the author. 
the 708 Club because the bandstand was behind the bar. It was at times unclear whether this was to protect the musicians from the audience or the audience from the musicians, given that performers at the 708 were renowned for attacking audience members who heckled. ${ }^{81}$

During the I920s and I930s, the Stroll, South State Street, represented the core of the South Side music community and the most overt example of the community's move toward autonomy. However, by the I940s, nightclubs in the city had grown beyond the Stroll. The clubs began to appear along Roosevelt Road (I2th Street), on the edge of Bronzeville, and the South Loop, and on Monroe Street, located within the core of the downtown area known as the Loop. These new clubs were emerging at the lakefront and running west through nonresidential areas of the city that paralleled the newly built expressways and an area of the West Side that would not become densely African American until the I96os.

Though there was an increase in blues and jazz clubs on the North Side by the I940s and into the I950s, few of the clubs employed African American musicians or were frequented by African American audiences. Among those that did employ Black musicians and accepted Black patrons were the Zanzibar, the Tay May, Dave's Tavern, and Sylvio's. These venues were all on the peripheries of African American residential areas. The downtown venues such as the Rialto, the Stagebar, and the Downbeat Room booked famous Black musicians, such as Duke Ellington and Cab Calloway, who were based out of New York and were not members of Chicago's Black union local. Chicago's Dinah Washington purposefully sought work in the downtown clubs because she knew that the audiences would be white and that this would help her singing career, as the white audience had helped Billie Holiday and Sarah Vaughan before her. Washington was not concerned that these venues discouraged Black patrons by seating them in the back of the club and charging them more for drinks. Nor was she concerned about the local Black musicians who backed her performance. In these clubs, Black musicians were prohibited from mixing with patrons and were verbally and physically abused by club owners. ${ }^{82}$

The audience may not have been fully conscious of the venue segregation because there were Black headliners, such as Duke Ellington or Nat "King" Cole, who played in the downtown theaters. These performers had the advantage of being famous and having a large white audience. In addition, many held union cards from locals outside of Chicago or the union's international card carried by traveling musicians who did not have a home base. ${ }^{83}$ From the perspective of the audience, Chicago was 
better than other cities because there were no whites-only signs on the theaters. If one had enough money, one could see the big names in the downtown clubs. ${ }^{84}$ When audiences, either white or Black, saw African American musicians perform outside of the South Side, they were probably unaware of the difficulties of the job for the bandleaders who may have been breaking any number of union rules, compromising their political and social beliefs to have access to a job, tolerating mistreatment by the club owner, or attempting to create new work patterns governed by different rules than in the legitimate venues.

While Black musicians had played outside of the South Side in the late I9IOs and early I920s, and the Black audience felt free to follow them, the segregation of venues, in accord with union segregation and paralleling the segregation of housing and public accommodations, had grown regrettably elaborate by the early I 950 os. ${ }^{85}$ Yet, appearances by Black headliners in the white sections of Chicago suggests that the segregation was still permeable by the I950s, a fact proven daily by the working musicians who were "scabbing" and undertaking other work activities that undermined the union. The existence of a porous segregation was not a sign of waning intolerance or racially utopian nightclubs; rather, it was a design flaw that musicians exploited whenever possible. For those trying to work in the system, it was clear that their "breaks" were only going to come from other Black musicians and outside of Chicago. ${ }^{86}$ What is also clear is that by the I950s, jazz and blues had moved beyond the South Side, but the majority of Black musicians were unable to follow. Where the South Side had once been a gilded cage capable of providing employment opportunities for large numbers of Black musicians, by the late I940s and early I950s it was a prison reinforced by both the city's and the union's racial traditions.

\section{BLUES MUSIC: ARTICULATING THE MIGRANT EXPERIENCE}

The generation of migrant musicians that came to Chicago during the late I930s and early I940s used their profession as a way of creating a discourse that challenged the social order, encouraged social movements, and articulated the needs and motivations of the underclasses. The result was a music that struggled to untangle the concepts of political and cultural power ${ }^{87}$ that were at the core of segregation. 
In constructing their discourse, the performers explored the trope of mobility by drawing on ideas of "North" and "South." By using the music to examine the individual's internal conflict concerning whether to stay in the North or return to the South, the musicians were able to examine the myths surrounding the city and the migrants' success there. The songs suggest that the songwriters saw their lives in danger of decaying under the pressures of alienating work and the loneliness of urban life.

Feelings of nostalgia for the consistency the South offered, as opposed to the unanticipated evictions and urban homelessness of Chicago, were constant themes in the music of this era. Consider Jazz Gillum's I94 I "Down South Blues," which imagines the South as a fallback position, suggesting that the migrants did not feel rootless:

It soon will be cold, you hear me sing, yes I mean, It soon will be cold, I ain't got no place to go,

I'm going back South, where the chilly winds don't blow. ${ }^{88}$

Cow Cow Davenport's "My Jim Crow Blues" suggest that the South in his memory was not only a point of departure and a place of torment, but, for better or for worse, it was dependable.

Lord but if I get up there, weather don't suit-

I don't find no brown. Go tell that bossman of mine,

Lord I'm ready to come back to my Jim Crow town. ${ }^{89}$

Memphis Minnie presented migration as a constant need, which brought the migrant poverty and harassment from police in "Nothin' in Ramblin,'" recorded in Chicago in I940:.

I walked through the alley: with my hand in my coat

The police started to shoot at me: thought it something I stole

The peoples on the highway: is walking and crying ${ }^{90}$

These lyrics offer an opposite view from the opinion of musicians such as J. B. Lenoir in his oral history. "The way they do's you down there in Mississippi it ain't what a man should suffer, what a man should go through. And I said, after I seen the way they treat my daddy I never was goin' to stand that no kind of way," Lenoir explained. He played for Memphis Minnie, Muddy Waters, and Chuck Berry. ${ }^{91}$ His success in the North 
may have shaped his feelings concerning the South-as is apparent when his experience is compared with that of Arthur Crudup, who worked and recorded music to earn enough money to return to the South. What can be concluded from the comparison of the song lyrics and the oral histories is that the songwriters were engaged in a discourse over the nature of place. These songs are part of a musician discourse that articulated a deep despair on the part of some new migrants in the I930s and early I940s as to their place in the city and their relationship to both the city and the mythologized South. In this way, the blues was a pronouncement of the choice to leave the South. It was the music of those who remained in the South, and those who decided to return. ${ }^{92}$

Bill Gaither's and Big Bill Broonzy's I94I "Creole Queen" described the migrants' hardships:

But since I been up North I been sleepin' on the bar-room floor.

I been on relief in Chicago and soup-lines in Kokomo (twice)

But I'm going right back down South where I won't be driven from door to door ${ }^{93}$

Compare Gaither's and Broonzy's mention of the "soup-lines" and being on "relief" to the redemptive mechanization of the ineffable North, such as airplanes and trains, as depicted in the gospel hymns, such as "Jesus is my Aeroplane"

(verse 3)

You can't find no soul to rest

Some of these mornings He's coming again

Coming through in a Aer-O-plane. ${ }^{94}$

and "Death is Riding Through the Land"

(verse 2)

Death is bringing down your great airplanes

Overturning automobiles

$\mathrm{He}^{\prime} \mathrm{s}$ wrecking trains causing hearts to fail ${ }^{95}$

The comparison of the lyrics of gospel and blues songs suggests that northern modernization was a divine act and suffering was corporeal.

The lyrics may not be suggesting that the migrant wanted to return 
to the physical location of the South or be mythologizing southern living in the same way that the minstrel songs, which were having a resurgence in popularity at the time, did by portraying the South as a kind of utopian hedonism synonymous with virility. ${ }^{96}$ Rather, the "I" seeks the familiar aspects of labor and the dependability of food and weather the South offered. This was a South of memory juxtaposed to the reality of poverty and grueling industrial labor in the North, which Broonzy and Gaither's songs understood to be Chicago. That same year, I94I, Broonzy recorded "Make my Getaway," which presented the opposite perspective on migration. ". . Gal I'm going up North," he sang, ". . . Lord, I'm gonna pack my suitcase, Boy I'm gonna make my getaway," ${ }^{\prime 97}$ which suggests that there was no consensus on whether or not one should migrate.

The lyrics examined above, and countless others from this generation of musicians, suggest that the drive to escape suffering was a unifying theme among the songwriters. More than that, the songwriters were using music to articulate the rules governing the relationships between people and their understanding of space. They accomplished this by using music to make visible the rituals involved in migration ${ }^{98}$ and through touring, which connected Chicago to other African American settlements. An example of this is Broonzy's "Going Back to My Plow," recorded in I94I. This song recalls the economics of the south as being a factor in the choice to migrate, saying:

Farming is all right, little girl if you know just what to do, (twice) 'Cause it killed my old grandpap, oh lord, I declare I'm going to make it kill me too. ${ }^{99}$

Broonzy's vision of farming shared a great deal with the field song that declared, "Ought's a ought, figger's a figger/ All for the white man. . . "100 His lyrics suggest that the relationship between Blacks and whites was the same as the relationship between Blacks and the labor. Both were governed by the inevitability of suffering. In this sense, Broonzy's songs depicted the South as a place of death by labor. Considered in the context of the gospel hymns produced in the same period, "Make my Getaway," like Broonzy's other lyrics, suggest that rapture, or death, offered the only freedom, and the only choice in life was where one would suffer. In this context, the North was preferable to the South because migration was a personal choice.

Broonzy's I94I songs may seem inconsistent with the historical nar- 
rative because it was a pivotal year in African American history. Chicago labor leader A. Philip Randolph, of the Brotherhood of Sleeping Car Porters, threatened to march on Washington if President Roosevelt did not desegregate the defense industry. Randolph was successful in forcing desegregation on the president and the industry in the summer of I94I. The opening up of these jobs was a huge shift. In I93 I, 43.5 percent of African Americans in Chicago were unemployed. By 1940, African American unemployment had dropped to I6.7 percent. ${ }^{101}$ The war meant employment for Blacks in Chicago, but it did little to alleviate the segregation in public housing, labor unions, and schools. As the blues songs suggested, the increase in employment did not end the feelings of alienation, brought on by the urban environment and the nature of industrial jobs, that Black migrants felt in Chicago.

Nor did the war end the idea that they might one day return home to the "South" if racism ended there. The I 947 song "Bilbo is Dead," which celebrated the death of Senator Bilbo of Mississippi, a legendary racist, suggested those who had moved to the city were "broke and had to get a loan." With the death of the senator, the migrants could "hurry back to Mississippi." The song suggests that migration changed a person forever; when the prodigals returned home, they felt like "fatherless" children and as the "lonesome stranger" in their "own hometown." 102

The Chicago lyrics of the I940s also suggest that there was diversity in the migration experience. It was in no way solely the smooth transition from southern oppression to northern prosperity that the leading African American publication, the Chicago Defender reported. Generally, the paper promoted institution-building and the Black middle class as stewards of the newly arrived laborers. In its crusade to inspire the migration of millions, the paper demanded "every black man for the sake of his wife and daughter should leave even at a financial sacrifice every spot in the South where his worth is not appreciated enough to give him the standing of a man and a citizen in the community. We know full well that this would almost mean a depopulation of that section and if it were possible we would glory in its accomplishment." ${ }^{103}$ The song lyrics suggest that the migrants found a different Chicago. They were struck by how cold it was and how that cold added an extra dimension to the demeaning experiences of starving and standing in relief lines, and the alienation they felt at being evicted. It is understandable that these themes appear in the lyrics from the depressed I930s, but there are elements of them in the lyrics of the more prosperous World War II era as well. Though jobs were 
prevalent in wartime Chicago and the previous "white-only" industriessuch as meatpacking and manufacturing-opened up, the migrants still experienced the conflicting longing for the southern Black community, while at the same time resenting the violence and poverty that the South guaranteed. The newspaper did not focus on these stories. Choosing to portray Chicago as the "Promised Land," indicated that the Black media were not altogether reflective of the migrant experience. The songwriters were using music to examine the myths surrounding the city, such as that of the "Promised Land" promulgated by the Chicago Defender. It also ensured that the musicians would grow in popularity and become harbingers of a new age of transformation in the city, in the music, and in the reach of the segregationists.

\section{"JAZZ IS DEAD": THE CHILDREN OF THE MIGRANTS}

By the I940s, a generation of dissatisfied youth began to emerge among the musician community. They were the children of migrants, and many had migrated as children to Chicago. This group had experienced the range and the contradictions of discrimination in the city, which left some feeling that the culture of the Western world was a "dead culture" and the Black music tradition was an artistic prison. ${ }^{104}$

The musician youth had a number of shared experiences. Many grew up on the South Side of Chicago. As children, they watched Louis Armstrong with King Oliver's Creole Band perform, and they were well aware of the great Black intellectuals. Many of the migrants' children were trained as musicians by Captain Walter Dyett-the music teacher at DuSable High School and one of the leaders of the Black union local. Others found Dyett difficult to be around and preferred to study in conservatories. They benefited from the scholarships, competitions, and education programs of the NANM. When the young musicians left the Black neighborhoods to attend the University of Chicago or Northwestern, they were confronted with the limitations of being African American in the city. At Northwestern, they were not allowed to live on campus, which meant daily train rides from the South Side. Once on campus, they were denied entrance to university spaces, such as the pool. For those who attended the University of Chicago, the reality of campus segregation meant that they had to walk from the Black neighborhoods into white Hyde Park. As they traversed the racial boundaries, they rarely saw other Black students, 
but they did see African Americans on their way to work as domestic labor in the campus area. Once they arrived in the university music departments, the young Black musicians found that their professors limited them to studying spirituals and Black choral music. ${ }^{105}$

When they were children, they benefited from the examples of the community's dedication to self-sufficiency in the public schools and churches. As professional musicians, they found that the Black-led union local-an example of the self-sufficiency movement-was powerless to help them find symphony and other well-paying jobs outside of the South Side. The lack of symphony and compositional employment forced many to change instruments, according to Milton Hinton, who started out as a violinist but had to switch to bass because it would be easier for him to find work if he focused on jazz bands. ${ }^{106}$

The employment situation was such that skilled and trained artists slowly grew "listless" and "lost any hope of aspiring to be anything," according to Hinton. He watched as his friends "reached maturity," and "if there was no place to work, I began to see them lose their creativity, and their hope for the future, and they began to settle for second best." Hinton recalled that those with academy training taught music while others "began to settle for going to the post office and working on the weekends. 'Get me a job at the post office,' which is a safe governmental job." 107

There were so many musicians and singers working at the post office in Chicago that there were two large choral groups, with supporting orchestras, composed entirely of Black clerks and carriers. The post office offered a degree of equality and security not offered in other jobs throughout the city, such as in the white-union-controlled manufacturing and slaughterhouse jobs, which were more commonly held by white musicians. ${ }^{108}$

Where as many chose the post office, others, like Hinton, found that they had to leave Chicago so that they could work as composers and musicians. For example, Margaret Bonds, born in Chicago in I9I3, studied composition at Northwestern University. Bonds spent much of her career composing music to accompany the poetry of Langston Hughes. Hughes had been a visitor to her mother's home, but she had never read his early poetry as a child. Instead, she discovered Hughes's poetry in the Evanston, Illinois, public library's basement when she was a student at the university. "I was intrigued," she wrote, "by his first published poem. . . I myself had never suffered any feelings of inferiority because I am a Negro, and I had always felt a strong identification with Africa, but now here was 
Top Ten Occupations, African-Americans (\%)

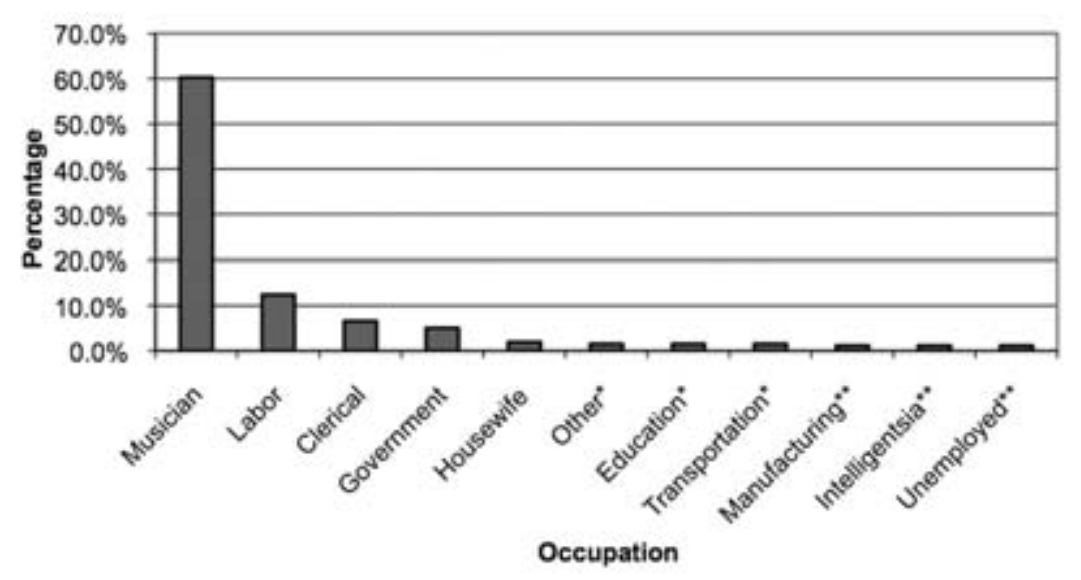

Figure 2: Statistics support Hinton's arguments regarding the type of day jobs worked by musicians. The chart is based on a census of I,984 death certificates of Black musicians in Chicago. The certificates were collected by the American Federation of Musicians upon the death of the member musician. By maintaining their membership in the union despite the fact that they were not making their living as musicians suggest that they continued to think of themselves as musicians.

this poem with so many different things I had known and was not able to express verbally." 109 This experience inspired her to write compositions based on Hughes's poetry-a decision that would bring her fame, as well as demonstrate how composers participated in the development of racial pride and used their skills to disrupt racism. ${ }^{110}$ To further her career, she had to migrate to New York, where her work brought together the freedom poetry of the Harlem Renaissance with the revolution in music at the heart of the Chicago Renaissance.

The frustration that drove Hinton's and Bonds's generation from Chicago also found expression in composer Edward Bland's 1959 cinematic opus, The Cry of Jazz. Born in Chicago in I926, Bland was well versed in the segregation of the city and the limitations placed on musicians both physically and artistically. In the film, Bland juxtaposed scenes of Sun Ra and his Arkestra with barbershops, pool halls, street corners, slums, and 
churches. Though the Black scholars of the previous decades found much to criticize in these aspects of African American life, Bland found these places to be at the heart of the Black struggle to constantly create, and recreate, Black culture and Black community. To view the places of Black life otherwise, Bland argued, would mean that the African American had accepted the "future-less future" of the "dehumanizing portrait America has drawn of him. ..."111

For Bland, contradiction between freedom and "restraint" was at the core of jazz because the need to repeat the chorus and the harmony limited the musician's creativity. The chorus in jazz, Bland argued, represented the "denial of a future and the American way of life," and the harmony reflected the "endless humiliation of daily life." Jazz composition was bound to these elements, just as African Americans were contained in the slum, Bland argued. In contrast, improvisation represented freedom, which Bland characterized as a "recreation of the present." Bland further contended that like the chorus and the harmony in jazz, the humiliations of segregation, poverty, and violence conflicted with the "negro's image of himself" found in the churches, the pool halls, the arms of a dancing couple, and the jazz band. These were the spaces where African Americans, according to Bland, explored the conflict between freedom and racial circumscription. ${ }^{12}$ In The Cry of Jazz, Bland symbolized these ideas in images of a burning slum, filmed on location in Chicago, and abandoned instruments lying around a player piano. Jazz could not grow "because it was not meant to grow," he insisted. Jazz was merely a "glimmering" of a "raising" consciousness that would transform America. "The jazz body must die because the restraints on the Negro must die," Bland argued. The jazz spirit, he promised, would "remake serious music, but the sounds of jazz will not be used."

Bland's call to deemphasize the Black music tradition stemmed from his belief that by the I950s the white audience had come to see blues and jazz as the only possible expression for African American popular musicians, just as the academic world had come to see spirituals as the only possibility for the classically trained African American musician and composer. He saw the constraints in music as parallel to the confinement of the ghettos. African Americans were not free, according to Bland, because they were caught within the limited imagination of the racist audience. The racist imagination had real consequences for Black musicians because it meant that they were not free to explore new forms of music 
or work freely in the city. The lack of freedom necessitated breaking with the past. ${ }^{113}$

If one were to wonder what happened to Chicago's classically trained Black musicians, composers of art songs, atonal and experimental composers, and the cutting-edge jazz musicians by the end of the r940s and beginning of the I950s, the answer is clear: they were working at the post office or they had left Chicago. As Bonds observed, musicians were trained in Chicago, but they worked in New York. ${ }^{114}$ The racial division in the music union ensured that they would not find jobs because there was no call for African American orchestral arranging and composition skills in the city. Bland summed up the musicians' feelings of disenchantment by saying, "I didn't personally know of any African-American that could've passed a Chicago Symphony audition ..." because of the symphony's institutionalized racism. In reflecting on his own compositional achievements, he wrote, "The only places I could've used those skills were in NYC, in Hollywood and European recording studios. . . ."115

For those musicians who continued to work and live in Chicago, there was a growing feeling that segregation had to be destabilized. If they were going to make a living as musicians, they were going to have to break the racial lines that governed the union, the venues, and the audiences. Only then could they spread beyond the confines of the South Side and the Black music genres to fulfill Nathaniel Dett's dream of a national culture defined by African American music and Edward Bland's dream of artistic, economic, and social freedom. As for the musicians who remained in Chicago they quickly learned the move toward integration came at a price in that it threatened the role of the Black-led institutions, at the core of the musician community, by suggesting they had outlived their usefulness. 
CHAPTER 3

\section{Redefining the Music Industry \\ Independent Music in Chicago, I948-I953}

Consider for a moment that Muddy Waters was a shareend of the 1950s, the Historical Statistics of the United States no longer listed the category of sharecropping as an occupation. His initial identity as a plantation laborer was disappearing in the United States. In addition, the railway line running from his plantation home to Chicago- the same railroad used by most of the African American migrants after the Great Depression-was out of service by the late $1950{ }^{1}{ }^{1}$

America had changed so much by the I950s that Howlin' Wolf, who would be one of Waters's greatest competitors, drove a two-tone DeSoto from Memphis to Chicago in 1952. He had \$3,900 cash in his pocket and was leaving his record contract with Sun Records, in Memphis, for a job with Chess Records, in Chicago. He claimed, "I'm the onliest one drove out of the South like a gentleman." ${ }^{2}$ Upon Wolf's arrival in Chicago, he rented a room from Waters. The Chicago veteran also introduced Wolf to the club circuit. Wolf would never scab, play on the street corners in the Maxwell District, or starve as Waters and the earlier generations of working-class musicians had; instead, he immediately took a regular gig at Club Zanzibar because by this time the electric blues was well established in Chicago. When Waters went on tour, Wolf filled in for him in clubs throughout the city. "I found it easy ...," Wolf said, "Cause the people had hears about me before I come: the records were out before I come to Chicago. Then I went 
to stretching out all across town. After people found I was there they commenced giving me jobs." Wolf knew his experience differed from that of the other musicians, and he was proud of it, declaring, "I only played at one house-rent party here. ${ }^{\prime 3}$

The divergent migration narratives of Waters and Wolf illustrate how much change had occurred in Chicago. Waters's motivation for leaving the South was not a record contract, but fear of violence from an overseer. He left the South carrying a suit of clothes and a guitar. Upon his arrival, he could not find enough work as a musician so he worked in the factories and drove a delivery truck. Wolf, on the other hand, came to the city with money in his pocket. He owned a car. He found work as a musician quickly. The differences in their narratives suggest that there had been a remarkable change between I943-when Waters arrived in Chicago, and I952-when Wolf permanently moved to Chicago.

The change had accelerated in I948 when Muddy Waters, partnered with independent European ethnic music producers and assisted by independent disc jockeys, resisted the American Federation of Musicians' ban on recording. For decades, Black musicians in Chicago had been practicing daily acts of resistance, such as "scabbing," but none of these acts had resulted in any significant change in the complex system of segregation that governed Chicago and the music industry. Resisting the union ban started a whirlwind of change in the music industry that pushed African American performers and music to the top of the music charts. Their domination of the charts was significant, given that in previous decades it was difficult for them to obtain recording contracts and radio would only broadcast white performers. ${ }^{4}$ By violating the ban and gaining access to recording and radio, the musicians had found a way to reach beyond the physical boundaries of segregation. Though African American musicians in Chicago were still unable to play in venues and found it difficult to live beyond the boundaries of the Black neighborhoods, white youth were able to buy Black music in the early I95os because of the use of radio and jukeboxes as a means of distribution. The momentary shift in industry power toward the independent record labels and the Black musicians only lasted five years, but it forever transformed the relationships between people and music in the United States. And it created an environment in which Howlin' Wolf could arrive in Chicago in relative comfort. 


\section{AFRICAN AMERICAN MUSICIANS IN CHICAGO: THE EARLY I95OS}

To understand how blues musicians were able to circumvent the segregation of the music industry, it is necessary to place them in a larger historical context. By I950, only New York had a bigger Black population than Chicago. ${ }^{5}$ The Chicago African American population had outgrown the Bronzeville neighborhood, which had been the home of the Stroll, and was spreading out into the South Side (for example, into the Woodlawn and Englewood neighborhoods) with pockets of population located on the far West Side and far North Side (particularly in the Little Hell neighborhood).

African Americans were not just growing in numbers. They were also gaining greater economic and political prominence. The spending power of the African American families headed by southern-born men and women had increased 33 percent in the r940s. The median income for southern-born African Americans living in the North rose from \$839 in I939 to $\$ 2,050$ by I949, making it equal to that of non-southern-born African Americans and \$I,00o less than the average median income of the southern-born whites living in the North. Housing, though still in the ghetto, had improved sanitation and had fewer people per room, according to I950 census data. Rates of home ownership had increased, as did health standards and educational opportunities. ${ }^{6}$ Most of these improvements were made possible by programs for veterans following World War II and the growth in industrial jobs in Chicago beginning during the war.

The circumstances of Black musicians in Chicago reflected the geographic and economic changes under way in the larger African American population. Until they began to record and could afford to move into the South Side, Waters's generation of musicians lived in and around Maxwell Street on the less expensive West Side—a formerly Jewish immigrant area of the city. ${ }^{7}$ In fact, Waters's first club gigs with a band came not because of his guitar playing or singing, but because he had a car and could transport the instruments. ${ }^{8}$ This suggests that the clubs and the musicians were moving along with the population as the borders of the Black area expanded. Judging from Waters's observations that the audiences in these clubs were entirely Black, the level of integration present in the audiences of the I920s had largely disappeared from the clubs by the late I940s. ${ }^{9}$ 
Waters emerged from the Maxwell Street community with a band composed of Jimmy Rogers on guitar, Baby Face Leroy on drums, and Little Walter on harmonica. Sunnyland Slim occasionally accompanied them on piano. This group was symbolic of the changes Chicago introduced to the music. In Mississippi, Waters had been a one-man band singing melody, keeping rhythm on the guitar, and stomping his foot to create a forceful percussion element in his songs. In Chicago, Waters and the other bluesmen played electric instruments, incorporated piano into their compositions, and adapted to drums so as to better compete with the sounds of the city. Waters used the Chicago band structure to alter the blues by adding to it a backbeat and by manipulating the beat with a delayed vocal style, which caused the musicians to delay the beat to meet the demands of the vocals. ${ }^{10}$ This band was only possible because so many musicians migrated to Chicago and because the wartime economic boom made it feasible for these men to afford electric instruments and cars.

As a band, they came together with the audience at the Zanzibar Club, half a block from Waters's apartment on the West Side. Opened in I946, indicating that the economy was good, the Zanzibar had no reputation or relationship with the more established musicians in the city. It was convenient, small, and open to new musicians. The bandstand was in the back, the bar was a semicircle in the middle, and the front was a delicatessen. The club owner, Hy Marzen, described Waters as "a bum off the street, just getting started." The sound was special because it was new, innovative, big, and loud. Most important of all, it was electric, which differentiated this band from the hundreds of others. Along with performing at the club, Waters's band continued to play house parties, though the club gig paid better. They understood that they were dependent on the migrant community and that house parties brought in more customers to the nightclubs. ${ }^{11}$

Without radio play, word of mouth and the community network of informal venues were essential to the musicians. The establishment of the relationship between the Black audience, the musicians, and the clubs was forming a culture of opposition that saw boundaries-such as those that racially divided the city and those that governed the music industry - as flexible. The audience was important to this process. If the musicians were going to disrupt segregation, they were going to have to draw on and alter the relationship between people and music. 


\section{FROM MIGRANTS TO MEDIA GIANTS: THE GROWTH OF INDEPENDENT MUSIC IN CHICAGO}

As the band's popularity grew, it picked up gigs at the Macomba-a club owned by the Chess brothers, Leonard and Phil. The Macomba was at South 47 th Street and South Parkway, where it shared the same block as the Savoy Ballroom, Regal Theater, and new apartments built to house the African American employees of Sears and Roebuck magnate Julius Rosenwald. Though African Americans were welcome in the club, as both performers and audience members, white patrons were given the best tables because the Chess brothers believed that whites were better tippers. ${ }^{12}$

Like Hy Marzen, the owner of the Zanzibar, the Chess brothers were Jewish immigrants. They were born in Poland and immigrated with their family in I928 to Chicago, where their father worked as a junk collector and bootlegger. Their father realized that owning the means of production and distribution was one key to success in the American capitalist system. This idea led him to combine his knowledge of running liquor with investments in the growing world of South Side nightclubs. His sons had a similar realization in the I940s. While watching blues performers in their club, they wondered if the club's patrons would buy the music to take home with them. ${ }^{13}$ With a business model based on bootlegging, the Chess brothers became Chicago's premier independent music producers.

The Chess brothers grew up in the Maxwell Street neighborhood, also known as "Jew Town," in the I930s, when the area served as a buffer zone between white Chicago and the South Side "black belt." The brothers were immigrant kids who spoke English with a South Chicago accent and syntax. Selling liquor and collecting junk with their father, they traveled the "black belt," where they heard the street and church music. Like the neighborhood they came from, the Chess brothers served as a middle ground between white Chicago and Black music. The Chess brothers were different from other Jewish Americans, such as Irving Berlin, who were drawn to Black music because they found commonalities between it and traditional Jewish music. The Chess brothers were pragmatic businessmen drawn to Black music because they saw it as profitable-not because they held romantic views of the music. They approached their relationship with musicians in the same way: Black musicians were employees, not artists. ${ }^{14}$ 
The brothers had a certain kind of genius because they recognized the commercial possibilities in Black music when the rest of the music industry did not. In the late I940s, the music industry classified African American popular music as "race music," which meant that it was a form of music marketed to and sold in areas of the United States with large African American populations, such as the Mississippi Delta, Harlem, and Chicago's South Side. From the I920s through the late I940s, there was little hope of radio play for "race music." Without radio, "race music" remained the music of the Black population centers. "Race music" was yet another way that Black music was tied to the segregation of housing and employment in the United States. ${ }^{15}$ The Chess brothers, though they lacked charm, had pragmatic imaginations and saw a different place for Black music in American culture.

In April I948, Waters's band recorded its first sides for the Chess brothers. It could have been just another record, but April I948 was the moment that the American Federation of Musicians union called for a ban on new recordings. The AFM went on strike in an attempt to challenge the Taft-Hartley Act's restrictions on union welfare funds. The legislation required that both the union and the employers manage the funds. The union's president, James Ceasar Petrillo, forbade musicians from doing any business with the recording and transcription companies. He threatened that the strike would be permanent and that the union would begin recording and selling music. ${ }^{16}$

The 1948 ban created a situation in which all recording companies sought to distribute product and were willing to violate union regulations to do so. Columbia and Victor suffered little from the ban because they sold older recordings, recordings made in Europe, and products other than music. The smaller companies, however, like the Chess brothers, faced devastation without new product. They had no overseas facilities or stockpiles of previous recordings to rely upon. ${ }^{17}$ So, being a company founded by former bootleggers, who were recording the music of other former bootleggers like Waters, the Chess brothers did the most logical thing: they ignored the ban on recording.

In the context of the ban, Waters's recordings-namely, his "I Can't Be Satisfied" and "I Feel Like Going Home"-constituted the popular music market. Released on a Friday, by Saturday morning the pressing had nearly sold out. Waters stood in the Maxwell Street Radio Company music store unable to purchase his own record, exclaiming, "But I'm the man who made it." It sold so well that dealers had to limit customers, both 
Black and white, to two copies apiece. Billboard reviewed it harshly, saying, "The Poor Recording distorts vocal and steel guitar backing." Nevertheless, it rose to number eleven on Billboard Magazine's "Most-Played Jukebox Records" chart, suggesting the popularity of the song was based on jukebox play and not on radio broadcasting. The ability of the song to rise so high on the chart meant that the song was in widespread distribution, which indicates that both whites and Blacks were listening. ${ }^{18}$ Later, Waters recalled that, while working during the day delivering venetian blinds throughout the city and at night driving to and from gigs, he could hear his record playing in the tenements. "I used to wonder if I'd died!" he said, "All of a sudden I became Muddy Waters. Just overnight."19

To this point, the release of Waters's record was the most overt and successful resistance to race-based economic limitations that Chicago musicians had mounted against the union's power and the inequalities of the music industry. However, to gain access to the segregated music market, Waters and other Black musicians had to go against their union. The Chess brothers' and Waters's act of resistance set a dangerous precedent because it suggested that liberating the musicians from the racism of the city could not be accomplished using the tools of Black-led institutions, such as union organization. Their defiance also suggested that one of the casualties of resisting segregation would be the institutions built by the Black middle class.

\section{THE RISE OF THE INDEPENDENTS}

The Chess brothers were victorious in the market because of Chicago. The geographic characteristics that made Chicago a transportation and industrial center-such as its central location and access to waterwaysalso made it a music city. All the major recording companies had offices in Chicago. Knowing this, musicians from throughout the South, both Black and white, traveled to the city. As blues guitarist B. B. King explained, a record made in Chicago would play all the way across the South and into central Texas. The musicians felt that they had a better chance in Chicago than anywhere else. ${ }^{20}$

The opportunity for African American performers to record in Chicago was a significant advance from the I920s and I930s, when few African American musicians had the chance to record. Jazz bassist Milt Hinton, who worked in the city in the I920s and I930s, remembered the city as 
not "being a very opportunist town for black musicians." Hinton recalled, "I don't think any black musicians ... ever received their just deserts in Chicago. I strongly feel, blame both the black union and the white union for this. ... I couldn't get a record in Chicago. I was proficient enough to play for studio orchestras, because I studied out at Northwestern University." To have greater job opportunities, Hinton switched from violin to bass. He explained the choice by saying, "there was no future. I couldn't even get in the pit with a violin. ... There was no way to make a living." The white musician, on the other hand, had the opportunity to record jazz in Chicago and "could go anywhere he wanted to," according to Hinton. ${ }^{21}$

It is clear from comparing King's and Hinton's experiences that a considerable change had occurred in the lives of Black musicians by 1948 and I949, when independent labels began to dominate the market. However, the Chess brothers were not alone in the Chicago market for long. Soon, they had competitors such as Change Records, which balanced the blues songs focused on sex with songs about social conditions. Art Sheridan, owner of Armour Plastics, founded Change Records. He set up shop at 20I I S. Michigan Avenue, up the street from Chess Records. Just as the Chess brothers' careers as club owners placed them in the position to produce music, so too did Sheridan's. His plant could press the records. Initially, he had trouble with the music union because the sidemen were not union members, but he must have resolved or worked around these issues because he went on to record John Lee Hooker and Little Walterboth union musicians formerly recorded by Chess. ${ }^{22}$

By 1953, it appeared that companies such as Chess were the establishment among the independents. The tactics that they had devised became the core of the upstarts' methods for creating new companies throughout the nation. The spread of independents out from Chicago included the founding of Sun Records, in Memphis, by Sam Phillips. A former employee of Chess, Phillips was well versed in how to develop talent and market music. Demonstrating that he had learned his lessons well, Phillips founded Sun by stealing away the best artists from Chess. These musicians included Howlin' Wolf, B. B. King, and Ike Turner's band, the Kings of Rhythm. ${ }^{23}$

Having been discovered by Ike Turner, Wolf sent chills through the independent business with "Moanin' at Midnight," recorded first for Sun. It was loud with enigmatic lyrics and featured distortion. To the Chess brothers, it sounded like a hit, and they released it on their label. The Chess brothers signed what they believed was an exclusive contract with 
Wolf, but other producers such as the Bihari brothers of RPM and Modern Records in Los Angeles also claimed that he had signed exclusive contracts with them. What grew from Wolf's business savvy was a confusing situation in which he recorded the same songs for different companies without the producers' knowledge. ${ }^{24}$

Wolf's various recordings for competing companies meant that his songs hit the charts in Oakland, Los Angeles, Chicago, Detroit, and throughout the South simultaneously, making African American music into a national market trend with access to the non-Black audience. Chess and RPM would battle over Wolf, as they did other artists, until I952, when he signed-temporarily-with Chess and then moved to Chicago. He was in constant demand because his music marked the beginning of a new trend that mixed the city blues with the rural style. ${ }^{25}$ He worked in the same genre as Muddy Waters, but Wolf had capriciously managed to do what Waters had been unable to do: unite a national demographic.

Billboard described the growth of the independent rhythm and blues labels-the new name given "race records" by the magazine-as "explosive." Each of the labels developed subsidiaries, creating a market consisting of more than roo labels. Billboard, fumbling to understand the phenomenon, explained that the field did not require "strong" artists or material to succeed because the artists did not have longevity, meaning many artists were one-hit-wonders. Some artists were able to pass the 300,000 mark in sales, but this was rare. Any recording selling over 40,000 copies was deemed a hit. The magazine was at a loss as to how so many labels existed in the small competitive market. ${ }^{26}$ Rhythm and blues may have succeeded partly because the lines between the music categoriespop, country, rhythm and blues-were blurring. Billboard admitted that the lines were arbitrary and "growing hazy" because records now hit on more than one of its music charts at the same time. ${ }^{27}$

The independents' success was apparent to the entire music industry by the summer of 1952 , when there was a slump in the music market everywhere except in Los Angeles. Billboard reported that Latinos were buying rhythm and blues recordings in larger numbers. The trade publication attributed the shift to the work of disc jockeys on the independent radio stations broadcasting throughout Los Angeles. Dolphine's of Hollywood, a 24-hour record shop, reported that 40 percent of its customers were white and buying rhythm and blues. The shop's owner was a disc jockey who created a quizzical promotion in which he gave away one free disc of his choice with every purchase. This move resulted in an increase 
in demand for rhythm and blues among the "pop audience," which Billboard seemed to indicate was European American and Latino. The new audience demand and demographic changed the concert business. African American blues musicians, who had once toured only in areas with a dense African American population, found their way to the West Coast for live performances for white and Latino audiences, suggesting that the music and the musicians were no longer confined to the American South or to Chicago. ${ }^{28}$

\section{THE DISC JOCKEY}

The seemingly sudden arrival of rhythm and blues performers and music in California in 1952 was evidence of a new player in the music industry: the disc jockey. Culturally, the disc jockey represented a shift in the music industry that coincided with the growth in the popularity of television sets. From I 948 to I952, 38 percent of the programs on radio migrated to television. Many believed that television would lead to the death of radio. In actuality, television simply replaced the radio as the center of family entertainment. Radio moved from the family room into automobiles and bedrooms. The invention of transistor radios further separated teenage listeners from parental control. Despite these advances in radio technology and the sustained audience growth, the radio industry had to overcome the loss in programming. The creation of the disc jockey was an economic move to replace the lost programming and to cut costs as the industry changed from live-orchestra performances, much to the ire of Petrillo and the musicians' union, to an individual playing records. ${ }^{29}$

There had been a slow increase in Black radio in Chicago due primarily to disc jockey Al Benson at WGES, one of only six Blacks among 3,000 announcers nationwide in the late I940s. While the other five Black announcers tended to prefer conservative programming that relied on Duke Ellington and Sarah Vaughan, Benson had no problem playing rhythm and blues. As a result, Chicago's rhythm and blues was finally being broadcast to Chicago. Because he chose to broadcast the music of the Black migrant class, Benson represented a break with the Black middleclass standards of broadcasting established by Jack Cooper's Negro Hour in the I930s. ${ }^{30}$

The African American disc jockeys in Chicago also transformed the sound of radio announcing by drawing on Black urban street culture and 
language. Initially, they copied the style of white announcers, which involved reading prepared statements. Benson was the first to break with the white tradition by introducing a working-class style of speech, or "jive" talk. By doing so, he legitimized the street culture and styles of the migrant class. Quickly, other disc jockeys throughout the Midwest and the South, both Black and white, began to copy his style, which relied on southern accents, Black idiomatic speech, and improvisation. Stations that were afraid to hire Black announcers hired African Americans to write scripts for white announcers. The widespread adoption of Benson's style by the early i950s led to the development of a standard for rhythm and blues, and later rock and roll, broadcasting, with Chicago as the center. ${ }^{31}$ Due to the geographic flatness of the Midwest and South, rhythm and blues radio station broadcasts from Chicago could be heard throughout the region and as far away as the Canadian border, taking the music and Chicago's urban street culture well beyond the South Side. Through the disc jockeys, Chicago's urban Black culture was crossing many socially constructed borders, including the physical lines of segregation. ${ }^{32}$

Almost immediately, the advent of the disc jockeys caused controversy in the music industry. Besides replacing live musicians, the switch to mechanically produced music damaged the music-publication business, which had formerly been the center of the industry. Songwriters had brought their work to the publishers, who then introduced it to orchestras, radio stations, and recording companies. Moreover, as letters to the editor and editorials written by industry insiders featured in Variety demonstrate, the major industry players decided that the disc jockeys, and not the overproduction that led to I 50 songs being introduced each week, were to blame for slumping sales and the creation of "false demand." For the major labels, payola (when a record promoter pays a radio station to play a recording) was the only explanation for how the records of the Chicago independent labels could outsell those of the major labels and dominate a national scene. After all, the major publishers and recording companies argued, the entire industry knew that Chicago was the "worst" of the payola towns. ${ }^{34}$

The major recording companies, like the older music publishers, were responding to a loss of control. For decades, the music industry had been an oligopoly in which a few publishers and recording companies dominated. In this system, there were powerhouses such as RCA Victor, which recorded the music and manufactured both the recording equipment and 
the record players. RCA Victor's major reason for recording music was to sell more record players. ${ }^{35}$

These corporations cultivated performers, making them into name brands, but by 1953 the power had shifted to the disc jockey, who had a direct line to the audience. It is arguable that the destruction of the "dictatorial elements of the music business" resulted in giving greater power to the audience. Statistically, it appeared true, because a hit song in the I930s sold I00,000 copies of sheet music and 80,000 records, whereas the best-selling songs in I95 I sold as many as 2,000,000 records with the possibility of selling half a million copies of sheet music. ${ }^{36}$ Why did sheet music matter? Simply put, sheet music represented the older music business that was slipping away in favor of a new business dominated by mechanical music rather than live performances. This shift meant a change in the way that musicians worked and reached the audience. What concerned the corporations was that, as an industry, they did not understand how to adapt to the new market forces.

The disc jockeys were at the heart of this change, for better or worse, because they were the ones who fished through the hundreds of releases each week and answered the phone calls from listeners demanding records. In essence, they were visibly building the pop audience and placing listeners in contact with music they would previously only have had contact with if they frequented the "black belt" bars of Chicago. Though the disc jockeys denied that payola dominated their profession, in their columns in Variety, the jockeys did not deny their power; neither did the music executives.

\section{MAKING CHICAGO'S BLACK MUSIC A NATIONAL MUSIC}

In December 1952, Sam Evans-an African American disc jockey on Chicago's WGES and a columnist for Cash Box, a trade publication focusing on radio and jukeboxes-argued that there was a growing demand for rhythm and blues artists on "pop" stations. He pointed out that the radio stations were facing a shortage in revenues partly because of the loss of audience to television but also because advertisers were seeking other venues. "It is regrettable," Evans noted, "that in this enlightened age, we only, and I'm speaking in general terms, find rhythm and blues shows on the smaller stations and then usually in the very early hours of the morn- 
ing or late at nite." Evans went on to argue that the rhythmand-blues audience was among the most loyal buying groups and was financially stable, though he offered neither evidence to support this statement nor demographics for the audience. Evans did, however, suggest that rhythm and blues broadcasts had to make do with advertisers such as

the town's credit jeweler, the credit clothier, the credit appliance house, the credit furniture store, the credit dentist, possibly a local beer and a huge assortment of "lay 'em straight" hair preparations. ${ }^{37}$

Though Evans did not name the race or class of the audience-it could be inferred from the list of advertisers that the stations saw the music as only marketable to working-class African Americans. He attempted to persuade the station owners that higher-end advertisers that would pay more for ads-such as department stores, automobile manufacturers, and appliance manufacturers-would be a better choice. If Evans was correct, there was a growing audience outside of the working-class Black demographic. This untapped demographic was listening to rhythm and blues. ${ }^{38}$

Statistics prove that Evans was correct. A 1953 disc-jockey poll conducted by Billboard revealed that 25 percent of stations reported playing more rhythm and blues recordings than in the previous year, 59 percent were playing the same amount, and I 5 percent reported a decrease. The stations reported playing an average of 2.5 hours per week of rhythm and blues. They rated pop records first in airtime, followed by country and western. ${ }^{39}$

A good case in point for the growing accessibility of rhythm and blues recordings beyond the African American audience to the European American teenager was the manner in which the career of Muddy Waters skyrocketed after the release of "Make Love to You." The song stayed on the charts the entire summer of I954. The song held sway over the public for a total of sixteen weeks-an indication that the growth of the Chicago independents and disc jockeys had changed the market.

The success of Waters's I954 recordings brought him a new audience, whom he met at the Alan Freed East Coast Moondog Coronation Ball. The advertising for the show was done exclusively over the radio, and primarily on Alan Freed's program. As a syndicated program, Freed's show held a certain amount of economic power because he replaced announcers on pop stations and created popular interest in music that the majority of the audience would have had no access to before his broadcasts. His first 
concert in 1952 attracted 25,000 teenagers. At that show, the performers were all from rhythm and blues, and Freed maintained this formula into I954. At the May I954 show, where Waters performed, most of the attendees were teenagers, and Billboard estimated that 20 percent of the audience was white. So many teenagers crowded into the Newark Armory for the show that they were unable to dance. ${ }^{40}$

Later that month, "Make Love to You" hit the charts. Billboard wrote that it broke strongest in the southern markets-including Atlanta, New Orleans, Nashville, Durham, and St. Louis. Billboard rated its sales as good in Cincinnati, Detroit, and upstate New York. The magazine urged northern dealers and operators to prepare for "possible surge in other areas also." The sales throughout the South and in Cincinnati, Detroit, and upstate New York correlated with the presence of rhythm and blues radio stations. Rhythm and blues programs were emerging all over the country, due partly to the syndication of Alan Freed throughout the middle and upper East Coast, Hunter Hancock throughout the West, and Zenas Sears throughout the South. These disc jockeys recorded their programs and sold the tapes to stations. Pop disc jockeys did not enjoy this kind of success because, as part of the network radio system, they seemed unable to break away from the idea that they had to appeal to regional tastes and discuss local affairs. The rhythm and blues disc jockeys sold their tapes to independent stations where the audience seemed only to require that the disc jockeys play music. To the recording industry, the reach of the disc jockeys meant that a record could break simultaneously throughout the United States. For the musicians, it meant that musicians like Howlin' Wolf could migrate to Chicago and make a living from their music. Beyond increased personal wealth, it created a marked transformation in the Black musicians audience. ${ }^{41}$

By August 1954, the growth in the numbers of European American teenagers in the audience at rhythm and blues shows prompted Billboard to announce that the music was "no longer restricted wholly to a $\mathrm{Ne}$ gro audience." Record stores, which had not previously sold rhythm and blues, now stocked it, and jukebox operators were reporting growing requests for rhythm and blues recordings from "pop locations which previously detested the low-down, noisy, but exciting numbers." Billboard estimated that Io percent to 20 percent of the recordings available on the Ioo-tune jukeboxes in the Midwest were by rhythm and blues singers. The majority of locations calling for this music were "teenage" hangouts, not roadhouses or saloons. An unnamed vendor reported to Billboard that 
he had made a tidy profit in Chicago selling jukebox records out of the back of his car to white youths. The vendor identified the most-requested artist as Muddy Waters. ${ }^{42}$

Teenagers were not only buying the recordings-they were changing the marketplace. On jukeboxes, requests for Black artists equaled or exceeded the requests for white artists performing the same song. The example given by Billboard was "Sha-Boom," which the Crew Cuts and the Chords both recorded in I954. Though the teenagers preferred the Chords, an African American group, the majority of disc jockeys could not play the recording because station managers often attempted to prohibit the broadcasting of African American artists on pop stations. Lack of radio play made jukeboxes and sheet music vital to the growing white audience, which had difficulty finding the music because of the racism of the radio stations. On the West Coast, high-end retail stores, such as Crawford's and Martindale's, began to stock the recordings. Black popular music also reached Europe because American rhythm and blues labels signed with distributors in Great Britain. ${ }^{43}$ The changes in distribution, promotion, and audience demographics had come together. Rhythm and blues performers had breached the segregated lines that had previously kept their music from traveling beyond African American listeners.

The youth were transforming the racial boundaries, according to Billboard, that had previously contained music. They drove many of the changes in the music industry, which responded at first by trying to reproduce the recordings using artists signed to the major labels. Rhythm and blues artists would break through on the pop charts and their recordings would move into the pop territory. The pop artists rerecording the rhythm-and-blues composition would not have the same success because teenagers preferred the original rhythm and blues artists. ${ }^{44}$

For Black musicians, the growth in the audience was both good and bad because with them the white audience brought a high level of racial tension. In a show at the University of Mississippi at Oxford, which Waters remembered as being before James Meredith registered there in 1962 but still during the height of the popularity of the "twist," the audience was entirely white. The "twist" complicated the show because as the coeds danced, their undergarments showed. In this setting, Waters singing songs like "Make Love To You" could be deadly. Fearful of the audience, the band looked away. "I had my head over, looking like a pump handle," recalled Waters. Drummer Willie Smith remembered that the young ladies' dancing and the presence of the Black musicians disturbed the col- 
lege matron, who turned out the lights, presumably to prevent the band from watching the students. The band finished the performance in the dark. Then the matron forced them to leave the hall through the kitchen, and they had to fearfully wait in the car during a rainstorm until someone brought out their paycheck. The performance, the fear of the musicians, and the actions of the matron demonstrate that not all segregation lines had disappeared just because the musicians, the independent labels, and the disc jockeys had remade the music industry. ${ }^{45}$

Nathaniel Dett, one of the founders of the National Association of Negro Musicians, had dreamed, in the first decade of the twentieth century, of the emancipation of African American music. Dett could never have imagined that African American blues musicians, including former sharecroppers, would be invited to perform at the University of Mississippi. The white teenagers' interest in the music from the South Side had its consequences. Popularity with white teenagers placed the musicians and the music on a dangerous precipice, with much yearned-for emancipation and fame on the one side, and the unwanted attention of cultural segregationists on the other. 
CHAPTER 4

\section{From South Side to the South and the Nation, 1954-1963}

In April 1956, Nat "King" Cole took the stage in Birmingham, Alabama, before a white audience of 3,500. Cole was the final performer in an integrated tour featuring singer June Christy and the Ted Heath Orchestra-the first British jazz orchestra to tour the United States. As Cole took his place center stage, someone in the audience yelled racial slurs. Cole ignored the jeers and began to sing his recent hit, "Little Girl." He was only a few bars into the song when five white men ran up the aisles of the theater, jumped on to the stage, and attacked him. The police were able to rescue Cole and capture the five men. Due to his injuries, Cole was unable to finish the performance for the white audience, but was able to perform later that evening, in the same venue, for an all-Black audience.

In the days that followed, the police reported that the five men all had records for previous violence and general misconduct. Furthermore, four of the men were members of the local Citizens' Council. When asked why they attacked Cole, one of the men explained he could not stand a white audience applauding a Black man. Had the attackers' plans been successful, there would have been I50 men present to attack Cole. Luckily for the singer, only five men showed up that night. ${ }^{1}$

After the attack, Cole returned to Chicago, where he had grown up singing in his father's church and studying music in the public schools. ${ }^{2}$ He hoped to find solace and further medical treatment for his injuries there. While he recovered, he found himself assailed by the Chicago Defender and the NAACP because they wanted all Black performers to refuse to play before segregated audiences. Alive in the minds of the newspaper editors and the NAACP was the Montgomery Bus Boycott then 
underway in Alabama and the Supreme Court, which at that time was hearing a case regarding the segregation of interstate buses. By performing in front of a segregated audience, Cole's critics said he appeared to be endorsing segregation. The newspaper called the attack a good lesson for Cole and any other musician who was willing to perform under such conditions. In response, Cole explained that both whites and Blacks bought his recordings and that both groups deserved to see him perform. He also explained that the five men had wanted to start a race riot but failed because the rest of the audience did not join them. Furthermore, Cole said that numerous white leaders, including the mayor of Birmingham, had apologized for the incident. For Cole, the reaction of the audience and the white leaders was an indication that the South was changing. Despite his explanations, the singer was unable to redeem himself in the eyes of Black leaders for performing before segregated audiences until he agreed to become a lifetime member of the NAACP and headlined $\$$ I, ooo-a-plate fundraisers. ${ }^{3}$

The attack in Birmingham was not Cole's last encounter with racism. He had achieved immense popularity by I956; his live performances were sold out; all of his recordings were in the top ten for sales; and his audience was growing and racially diverse. Not surprisingly, late that same year, Cole became the first African American to headline a network television show. However, after only sixty weeks and record-breaking ratings, NBC announced that Cole would not continue as host, citing his touring schedule.

The truth behind the cancellation was that NBC had difficulty finding sponsors and navigating protests from southern affiliates. Cole's celebrity friends guest-starred on his show in hopes of drawing in sponsors, but to no avail. His popularity had created the possibility of hosting the show. Fame also caused Cole to be caught squarely between the segregationists of the South and the appeasers in the broadcast industry. ${ }^{4}$

When Cole took the stage in Birmingham, he was colliding with a historic moment. He did not intend to become a symbol of the changes in the music industry that made it possible for an African American performer to become a superstar, nor did he intend to become a symbol of integration. All he was trying to do was perform and present a positive image of African Americans. The men who attacked him saw his performance differently. For southern segregationists, Black music and Black musicians were part of what they perceived to be, in the words of Citizens' Council leaders, an NAACP "plot to mongrelize America by forcing Negro culture 
on the South. ${ }^{\prime 5}$ In the minds of Citizens' Council members, Cole was as dangerous to the white community as rock and roll.

The Citizens' Council was partly correct. Many African American performers were actively using their popularity among white teenagers to help integrate the South. ${ }^{6}$ If the fears of segregationists are any indication, these performers were finding success on the integration front. ${ }^{7}$ What the southern segregationists failed to understand or acknowledge was that there was a massive cultural change underway in the United States in the mid to late I950s. To the white supremacists, the music and the musicians were representatives of "Negro Culture." In actuality, the music was also illustrative of a growing white national audience responding to music and performers who embodied the urban African American culture of the Midwest, specifically Chicago. ${ }^{8}$

The musicians of the Great Migration were returning South. The music that they brought to the South, and that spread throughout the nation in the 1950s, was an outgrowth of the rise in Black consciousness and self-importance that the Fisk University sociologists had noted in their I940s study of the Mississippi Delta. When the musicians migrated, they went to Chicago, and other Midwest cities. As their music flourished, so did the musicians' racial pride and cultural power. When they toured the United States, and specifically the South, their music represented the erosion of institutional segregation's ability to control the spread of music from the northern cities to the Delta and to contain Black culture in the urban ghettos.

Fueling the growth in the popularity of the music was the rise in the Midwest of independent record producers, jukebox operators, and disc jockeys who, along with the touring musicians, made African American music accessible to a national audience. In so doing, the independent producers, distributors, and broadcasters mobilized the advantages afforded them in the Midwest and challenged the power of the major corporations to control product and distribution. Just as the white supremacists were challenging the emergence of the music into the mainstream culture, so too were the corporate leaders of the music industry.

One reason for the opposition to Black music was that wherever the musicians and the music went in the United States, discussion of civil rights followed. The musicians were changing the debate concerning integration. Up until now, integration was a discussion concerning rights in the public sphere-voting, buses, housing, and schools. However, every 
time a white teenager bought tickets to see a Black performer or tuned the radio to a Black station, the discourse concerning the appropriate place of Blacks and Black culture became an issue of the private sphereteenagers' bedrooms, teenagers' hangouts, and teenagers' cars. ${ }^{9}$

The rise in popularity of Black music was one element in a changing culture that continued to demonstrate that white supremacists were losing ground. For their part, the changes that Black musicians had endured through southern racism, migration, and urban segregation were made manifest in the music. The growth in the white audience and the transformation of the regional music of the urban Midwest into a national music meant that in the mid-I950s both the artists and their music had emerged as more than an expression of Black dignity and survival. The popularity of the music and musicians was an indication of a looming national collision between those who were steadfast in their defense of traditional race relations and those who danced in integrated clubs. ${ }^{10}$

\section{"OFF-COLOR": RACE MUSIC BY ANY OTHER NAME}

The fight against Black popular music in the I950s was not solely the work of white supremacists. In I95 I, African American poet Langston Hughes voiced concerns about music played over loudspeakers outside of record stores in Chicago's Bronzeville neighborhood. Hughes was afraid that children and the elderly would hear the lyrics of rhythm and blues. Also in I95I, Chicago-based Jet magazine argued against the lyrics in rhythm and blues recordings. ${ }^{11}$ In I955, civic leaders from Houston's Juvenile Delinquency and Crime Commission prepared a list of objectionable records and the group forced all of the nine local radio stations to refrain from playing the songs. The head of this group was Dr. H. A. Bullock, an African American sociology professor at Texas Southern University. ${ }^{12}$ In short, the move to suppress popular music was not entirely led by whites. In addition, the music did not become of civic concern only when whites became aware of it. The difference between the views of African American leaders and white leaders was that African American leaders saw the music as a problem with the music industry, whereas white leaders more often than not saw the "obscenity" of the music as rooted in the core of Black culture, which they saw as a threat to white youth.

In the I950s, the fear of the influence of Black culture on white youth 
amounted to a domino theory of music in which it appeared that white youths were falling one by one into the abyss of Black culture. The opponents of the music argued that "popular music" was popular because the radio disc jockeys and jukeboxes made the music available to anyone regardless of age or race. Therefore, the music was dangerous because the spread of broadcast technology circumvented the power of institutional segregation to contain African American urban culture within the ghettos on the South Side of Chicago. Recorded music had disrupted the traditional power structures, and this made it more dangerous than the clubs on the Stroll in Chicago in the 1920 s had ever been. ${ }^{13}$

Variety, the entertainment industry's primary publication, articulated and solidified the fear of the influence of Black music on white youth. In a three-month-long campaign against rhythm and blues music during I954-I955, Variety made it clear that the problem was Black culture influencing white kids. In condemning rhythm and blues, Variety used a language flexible enough that numerous songs fell within the boundaries of the definitions of "off-color" - a euphemism that the periodical used to link race with notions of "smut." For instance, in an editorial titled "A Warning to the Music Business," Variety accused the music industry of purposefully contaminating popular culture with Black culture. The editors described the dangerous lyrics as being phrases such as "rock and roll," and terms like "hug" and "squeeze." They characterized these "leer-ics" as "back fence language" and as "earthy dialogue" that "belonged in 'art novels." ${ }^{\prime \prime 14}$

Variety added that the problem with the music was more than the lyrical content. "In the past," the editors wrote, "such material was common enough but restricted to special places and out-and-out barrelhouses." They continued, "today the 'leer-ics' are offered as standard popular music for general consumption, including consumption by teenagers." While arguing that there was a suitable audience for this style of music, Variety asserted its accessibility of the music to white teenagers was the true problem. ${ }^{15}$ In fact, the editors hearkened back to the music of influential jazz musician "Jelly Roll" Morton, who had migrated to Chicago with the first wave of New Orleans musicians in the I9Ios. In the I920s, Variety had labeled Morton's music as "smut." In I954, the editors revisited their previous calls to limit African American music by arguing that Morton was not a threat to society because he was in the "music underworld" and not the "main stream." ${ }^{16}$ In other words, had the music continued to be limited to the South Side of Chicago, where Morton 
performed, there would have been no need for concern. After all, the editors suggested, there was a reason why rhythm and blues was once called "race" or "Harlem" records. The crisis of American youth, according to the publication, stemmed from the fact that Black vernacular music, whether it was called rhythm and blues or "race" records, was no longer "limited to Harlemania." 17 The Variety editors had made it clear that race determined the music's suitable audience. The "kids" in Harlem were not the same "kids" that Variety was seeking to protect. "Race" records were suitable for Harlem and "barrelhouses" because these represented contained cultural spaces defined by economics and by race.

In the context of the Cold War, Variety argued, the breach of the color line placed the nation in great peril. In 1954, the State Department was preparing to spend $\$ 2.25$ million as "seed" money to fight the Cold War on the "Cultural Front." It funded world tours of, among other things, the New York City Ballet, productions of Porgy and Bess, and jazz orchestras. By sending American culture abroad, the State Department hoped to promote what Variety called the "American way." The State Department presented jazz, which included hiring Louis Armstrong and Dizzy Gillespie $^{18}$ as cultural ambassadors, as an example of American ingenuity and independent spirit, rather than as a music created by one of most oppressed segments of the population of the United States. As a result, the "picture of America" presented to the Cold War world was defined and controlled by the standards of those at the center. The music of the periphery, such as rhythm and blues, was "lewd," and, Variety argued, "it gives a very false picture of this country." The questionable music was, according to the editors, "deplorable and contrary to the best interests of this country and democracy." "What is bad for the youth of America is also bad for the youth of England and other countries where English is spoken or sung," proclaimed Variety. ${ }^{19}$

Variety was not alone in questioning the value of certain forms of popular music. Billboard, Variety's rival publication, also referred to certain recordings as "off-color disks." Unlike Variety, Billboard asked how "clever" lyrics could be separated from "obscene" ones and its editors contacted various small rhythm and blues labels for comment. Bess Berman of Apollo Records and Herman Lubinsky of Savoy Records denied ever putting out an "off-color" recording and argued that obscenity was an unfortunate interpretation on the part of the listener. The executives of the larger Atlantic Records, Ahmet Ertegun and Jerry Wexler, stated, "We endorse any movement against offensive content on records," and, 
like Savoy and Apollo, denied ever distributing obscene records. The Atlantic executives went further by saying, "it strikes us as unfortunate that rhythm and blues records are singled out for censure at this time when instances of questionable material abound in the pop and country music fields as well." They called for every effort to be made "to facilitate a continuously wider acceptance" of rhythm and blues, "this basic American music." 20

For Billboard, the success of rhythm and blues derived from the "intrinsic quality of its product, the lure of its exciting music, the craftsmanship of its a\&r [artists and repertoire] men, the top quality of its artists." Despite this glowing review, the editors of Billboard still felt the need to call for "the occasional distasteful disks" to be "weeded out" by "wise, tempered judgment" on the part of the radio stations. The editors argued that the broadcasting of questionable material was contrary to the "public good." Therefore, it was a violation of the terms of broadcasting licenses of the stations and should attract the attention of the Federal Communications Commission. The licensing process, in part, motivated the television and radio industry's sensitivity to the moral demands of the audience because, though the corporations owned the transmitters, the public owned the airwaves and thus could control content. ${ }^{21}$

Billboard had an agenda in publishing this editorial: the editors did not want to be held responsible for the content of the music promoted in their magazine:

The Billboard's Best Selling charts are not necessarily a carte blanche programming recommendation. These charts reflect sales.... The stations using the charts should exercise judgment and eliminate from their programming disks which, in the station's opinion, do not qualify as home entertainment. Adherence to this principle will reduce to a minimum the number of such disks which enter the best-selling category. ${ }^{22}$

This cautionary statement concerning the use of the charts is interesting because it sought to distance the editors of Billboard from the playing of questionable music and place responsibility on the radio stations. However, the editors failed to note their own role in promoting music. When a song placed significantly on the top-twenty list, it then attracted the ire of the censorship movement. Writing the song, performing the song, and recording the song did not violate the public good. Under the Bill- 
board and Variety arguments, the songs only endangered the public upon broadcasting-either on the radio or jukeboxes. In addition, the editors of Billboard saw the necessity for banning rhythm and blues, but did not discuss the questionable lyrics in the pop and country-and-western musical genres, which the executives of Apollo, Savoy, and Atlantic Records all noted as containing sexual content.

Though Variety and Billboard dominated coverage of the music industry, there were smaller publications defending the positions of niche markets. An example of the smaller publications is the Cash Box-a biweekly paper reporting on the jukebox industry. In September 1954, the Cash Box warned its subscribers of the problems that "dirty" rhythm and blues recordings could cause for the industry if cities and towns were to establish censorship boards. Its editors predicted that the music would be blamed for the rise in juvenile delinquency, and all evidence of "ameliorating delinquency conditions" would be ignored. The looming threat of censorship, which reformists justified by citing rising rates of juvenile delinquency manifested through violence at music shows, would hurt the entire jukebox industry, according to the editors. To survive, the Cash Box suggested that the industry censor itself. ${ }^{23}$

Audiences accessed the music through unregulated jukeboxes. Owners of the machines filled the jukeboxes with rhythm and blues music because the recordings were cheap and jukebox music did not need to be registered, thus bypassing BMI (Broadcast Music Incorporated) and the ASCAP's (American Society of Composers, Authors, and Programmers) standards boards, which were the organizations that licensed music releases. On the surface, censoring jukeboxes appears to be a separate issue from the banning of music from the radio and from exportation. After all, Variety's editors clearly said, they wanted to protect the "kids," and jukeboxes represented the much-maligned "saloon" or "barrelhouse" trade. One would imagine that few children were present in saloons to hear the questionable music. Nevertheless, in controlling the jukeboxes, the leaders of the major recording corporations saw a way of controlling the kind of music that reached a wide audience and of curtailing the success of the small labels.

The fight against jukeboxes began in earnest in I953, when six counties in South Carolina outlawed the machines, and continued into I954, when police departments across America began to seize the machines and fine their owners. While economic competition motivated the larger recording companies' support of restrictions on jukeboxes, morality stan- 
dards and racism motivated community-based opposition. In Chicago, a judge ruled that organized crime controlled jukeboxes and thus that the machines were a detriment to the community. ${ }^{24}$

The major music corporations supported the regulation of jukeboxes because in economic terms the jukeboxes represented a means of distribution. The economic position of the machines was significant because, essentially, a major label is one that records, presses, and distributes its own recordings. In the I950s, Mercury, which formed in Chicago in I947, and Capitol Records were the only independents, or small labels, capable of this. The jukebox threatened to turn the music industry on its head because the machines could elevate the independents beyond regional producers and provide the means by which they could challenge the major corporations' market control. ${ }^{25}$

For its part, Cash Box defended the jukeboxes by arguing that the interests of the coin-operated-machine industry and those of the record industry were tied to one another. The jukebox operators relied on the product from the record companies, and the record companies relied on the machines as a means of distribution. In I955, there were 550,000 jukeboxes in the United States playing 25 percent of the record industry's output. The periodical reminded the record industry that the machines represented a profound opportunity for direct marketing. Therefore, the editors of Cash Box argued, if the jukeboxes fall, so does the record industry. ${ }^{26}$

For those periodicals outside of the music industry, the popularity of Black-derived music by white performers and audiences-in this case, rock and roll-was followed with mocking disdain by the mainstream press. The focus on, and use of the term, rock and roll was an indication that the popular periodicals were changing the music terminology from "rhythm and blues" because their critique focused on white performers and the white audience. For example, Time magazine described rock and roll lyrics as "either a near-nonsense phrase or a moronic lyric in hillbilly idiom." The magazine's reporters likened the incomprehensible nature of the lyrics to the equally incomprehensible behavior of the teenagers at rock shows. Dismissing the lyrics as trash, Time concluded that the popularity of the music was an "epileptic kind of minstrelsy" and "an adenoidal art form." ${ }^{27}$ The allusion to "minstrelsy" allowed Time to simultaneously degrade the abilities of the white performers, by suggesting they were mimicking Black musicians, and reiterate the fear of the power of Black culture expressed by Variety and acted upon by the southern Citizens' Councils. 
Of the non-music-industry publications, only the New York Times Magazine used investigative reporting techniques to answer the question: Why did many white teenagers enjoy Black-derived popular music? The teenagers explained it simply: they liked to scream. Though they often wished to scream at home or school, the rock and roll concerts were the only place they could scream. ${ }^{28}$ The teenagers' public, visceral reaction to the music was shocking to observers who argued that rhythm and blues, and later rock and roll, were "attempting a total breakdown of all reticence about sex," ${ }^{\prime 29}$ that rhythm and blues was "as dangerous to kids as dope," and that the "whole world is experiencing a moral retrogression." ${ }^{30}$

The media provided opponents of rock and roll with evidence of the connection between the music and juvenile delinquency. Throughout the late I950s, there was a rash of what the media and the court system described as "rock and roll riots." The frequency of fights at music shows, and fear of the possibility of fights breaking out, caused several city governments to pass anti-rock and roll legislation barring the shows. In Boston, following the outbreak of violence at a show he promoted, the famed disc jockey Alan Freed was arrested and charged with anarchy. In Fayetteville and Kansas City, the police put down fights at rock and roll shows with tear gas. ${ }^{31}$ Generally, the violence at rock-and roll-shows was between competing groups of whites, Blacks, and Latinos, which gave further fuel to the arguments against integration. ${ }^{32}$

The three-month-long Variety campaign against "Leer-ics," the incidence of violence at rock shows, and the agitation of community groups caused radio stations throughout the country to create their own censoring boards. ${ }^{33}$ During the I9Ios and I920s in Chicago, reformists had focused on performance spaces, such as the "black and tans," the brothels, and the dance halls. By the mid-I950s, reformists saw the music as a commodity in the form of a recording. The records frightened the reformists because they were not contained to Black neighborhoods, as the "black and tans" had been. Instead, the records were making their way to radio and jukeboxes and into the bedrooms of thousands of white teenagers, where the popularity of the records threatened to create a national "black and tan" culture. Viewing the music as something contained in the grooves of a record allowed the music's opponents to see its growing popularity as a sudden occurrence, thereby disconnecting the music from its long history and cultural importance. ${ }^{34}$ 


\section{THE DISC JOCKEYS}

Portraying changes in music as sudden provided a platform for opponents to address the recent tumult in the music industry, which had seen conventional popular music, such as Broadway scores written by Oscar Hammerstein and sweet jazz performed by Frank Sinatra, lose its market position. ${ }^{35}$ Variety was among the first in the entertainment industry to attack Black music. Its editors argued that rock and roll-and its forerunner, rhythm and blues-was the lowest form of cultural expression and the product of hack writers. Variety portrayed the popularity of the music as a trend created not by market demand but rather by corrupt business practices, such as payola and the music licensing done by BMI. ${ }^{36}$

ASCAP shared Variety's perspective. Like Variety, ASCAP was a founding member of the music business. The association formed in I9I4 as a protective guild that worked to ensure that songwriters and composers received royalties for their work regardless of where and in what medium the music was performed. Having formed in the days of sheet music, film, and radio, ASCAP was unprepared for the massive changes in the music industry brought on by television, jukeboxes, and the growing importance of disc jockeys. ${ }^{37}$

To its detriment, ASCAP was exclusive in its membership, which included George Gershwin, Cole Porter, and Oscar Hammerstein, but did not allow rhythm and blues, country and western, or rock and roll composers to join. Coupled with its failure to anticipate or to understand the importance of disc jockeys and television, the limitations on membership provided an opening for a competing organization. ${ }^{38}$

The end of ASCAP's control of the music industry began slowly in I94I when the organization launched an attack against NBC and CBS, and later ABC. ASCAP was demanding an increase in royalty payments. The three broadcasters retaliated by forming their own licensing organization, BMI (Broadcast Music Incorporated), which would function in the same way as ASCAP, but BMI would be under the control of broadcasters. The strike ended with a compromise. ASCAP accepted a 2.I percent increase in royalties from live performances on radio broadcasts; BMI would collect royalties from live performances not broadcast on the radio. ${ }^{39}$

For years, little changed. The major composers signed with ASCAP, and BMI had to be satisfied with the remainders: the Black, country, and Latin composers. It was disc jockeys and television that disrupted this 
system, or so it appeared to ASCAP, which argued that the rise in the popularity of rhythm and blues, and later rock and roll, was due to the relationship between BMI and broadcasters. According to ASCAP, BMI was a monopoly that used payola to promote its artists..$^{40}$ Therefore, rhythm and blues not only threatened white teenagers but was also the product of corrupt market practices.

The ire of the Variety editors, community groups, and city councils had created an atmosphere in which congressmen were interested in investigating the impact of the emerging popular culture trends in music, movies, and publishing on American youth. In addition, Congress was investigating corruption on the popular television quiz show, The $\$ 64$, ooo Question, which was so scandalous as to suggest that major corporations were engineering all popular culture trends. ${ }^{41}$

Ultimately, ASCAP was unable to make its case that BMI was a monopoly because statistics showed that 85 percent of copyrighted music played on the radio, and 90 percent of copyrighted music on TV, was licensed by ASCAP. These statistics came from ASCAP's own data. On the other hand, with respect to the relationship of disc jockeys to broadcasters, ASCAP's charges of payola stuck. ${ }^{42}$

Historically, the disc jockey represented a cultural shift in the music industry that coincided with the debate concerning the place and power of Black culture. The power of the disc jockeys seemed to originate from the fact that they made their own playlists. This encouraged recording companies to pay them off, to supply them with the newest releases, and to court them. Leonard Chess, the owner of Chicago's Chess Records, made no secret of the fact that he bribed disc jockeys. In fact, he reported the bribes on his tax forms. He was only doing what every other company did. ${ }^{43}$ However, it would seem that the tastes of the disc jockeys and those of the audience must have had some role, because the Chess recordings were played despite the fact that Chess was not wealthy enough to compete with the bribes that the major corporations paid. Although they were responding to some degree to audience demand for rhythm and blues, the disc jockeys were a target of ASCAP and Congress because they were the most obvious sign of change in the music industry and attacking them was the easiest way to halt the playing of certain types of records.

Disc jockeys went relatively unchecked until 1959 when Congress, spurred by ASCAP and the corruption on The $\$ 64$, ooo Question, took an interest. Several disc jockeys testified at the hearings that payola was responsible for the popularity of rhythm and blues, country and western, 
and rock and roll. The congressmen were satisfied to believe this despite testimony to the contrary-such as that given by Billboard magazine music editor Paul Ackerman, who insisted that payola payments to radio stations were standard practice as far back as the I930s. ${ }^{44}$

The most famous casualty of this turn of events was Alan Freed, who was fired after refusing to sign a statement saying he had never received payment for playing a record. Eventually, Freed paid a $\$ 500$ fine and served six months in prison. The scandal also touched Al Benson, the leading African American broadcaster based in Chicago. Chess Records had paid Benson approximately $\$ 900$ a week. It was impossible to prove that Benson had accepted payola because he distributed the money among various personal businesses. ${ }^{45}$ The payola scandal stripped the independent disc jockeys of some of their cultural power because they would never again have the trust of their audience, nor would they be allowed to program their own shows without the shadow of corruption hanging over them.

Did the curtailing of independent disc jockeys change the way music was broadcast? The answer to this lies in contrasting congressional investigators' treatment of Alan Freed and Al Benson, who were independent disc jockeys playing rhythm and blues, and that accorded Dick Clark, a mainstream disc jockey and television host. While Benson and Freed were fined and destroyed by the congressional hearings and grand-jury investigations, Dick Clark was not. Clark may not have taken payola payments, as such, but he did own stock in the recording companies and publishing houses whose songs he played on his radio and television shows. He also owned the publishing rights for songs and was the paid representative of performers featured on his ABC television show, American Bandstand. His yearly salary in the I950s was estimated at $\$ 500,000$, with an additional estimated \$I2 million in music-company stock. At the time, it was not illegal for Clark to own stock in the companies whose songs he promoted on his television show. ${ }^{46}$

As a result of the payola hearings and trials, the music of the major corporations remained the core of radio and television broadcasts, while the music of the independents was limited. ${ }^{47}$ The differences in the treatment of Alan Freed, Al Benson, and Dick Clark reveal the dynamic at work. Freed and Benson represented Black performers, often playing music with overtly sexual lyrics, for an integrated audience. Conversely, Dick Clark's American Bandstand featured white performers, white audience members, and white dancers. Teenagers on the show followed a 
strict dress code and dance rules that reduced, or eliminated, the show's sexuality.

\section{THE REACTION OF THE MUSIC INDUSTRY}

In the national atmosphere of fear of Black culture, larger companies had a better chance of surviving because they had diverse products and groups of artists. In addition, the Variety editorials brought the fury of licensing associations and distributing companies down upon the smaller companies. ASCAP offered Variety assistance in "an endeavor to root out the evil," and the association of songwriters placed the responsibility "at the doorstep of the recording companies and those broadcasters who encourage or condone the dissemination of the "leer-ics." In addition, the Music Operators of New York proclaimed that they would "ensure that no record is played in a coin-operated phonograph that could not properly be played in the home" and that the music industry could not "endanger the public good will . . f for the quick profit of any individual who trades on bad taste." Moreover, distributors such as United of Houston "started a thorough screening process of all records, especially r\&b discs, and refused to sell any that were offensive or suggestive." Eventually, BMI responded to the call for censorship by distributing a list of "play with caution" songs to BMI affiliates. ${ }^{48}$

The major labels responded in a similar manner. In the spring of 1955 , Columbia Records launched a new advertising slogan for its catalogue of popular music: "Rhythm without the Blues." ${ }^{49}$ This slogan brilliantly summarized the major label's stance. The label was willing to record Black-derived music but stripped away the African American artists and their music traditions from the popular hits.

At first, in the late I940s, the major corporations had been able to ignore the success of the independent labels and Black music. By the start of the I950s, however, it was clear to everyone involved that Black music was profitable. "Covering" refers to recordings made by competing music labels. "Covers" were replicas of the original recording featuring a different artist. ${ }^{50}$ Labels, such as RCA Victor and Columbia Records, closely watched the independent labels for "potential hits" to cover. The larger labels had the star power, advertising budgets, and distribution networks to force radio and television networks to play their version of a song. ${ }^{51}$ However, profits from "covers" were negligible because a portion of the 
song's royalties went to the songwriters who worked for the independent labels.

When "covering" failed to bring in large profits or destroy the independents, the major corporations encouraged radio stations to have smaller play lists limited to forty songs recorded by the major companies. Previously, the playlists were huge and created by the disc jockeys. The smaller playlists were advantageous for the major labels because they had relationships with the advertisers and radio stations that the independent labels lacked. Major corporations, using the top-forty playlists, were able to squeeze out competition, remake their production around a limited product, and minimize the risks by limiting new styles of music. The topforty system did increase payola payments to disc jockeys by independent labels desperate to have their records played. Major labels made payola payments but were not dependent upon them, as the independents were, because they had advertising budgets. After I959's congressional payola hearings, the independents had a far tougher time convincing stations to play their records.

When the independents started to emerge in the I940s, they used antiquated methods, in terms of machinery and materials, for recording, and had outside firms press the records for them. They relied on acetate masters and shellac 78-rpm records in an era when the major labels were switching to magnetic tape for masters and vinyl for the records, and were then were developing long playing records for classical music and 45-rpm records for rock and roll. By the mid-I950s, the 78-rpm record was the standard for the jukeboxes, which gave many independents access to the jukebox market. The major corporations began to send the smaller, lighter, and more resilient 45-rpm records to radio stations in I954 and jukeboxes slowly began to adopt them. Eventually, by the end of the I950s, the industry standard would be 33 I/3-rpm records, but many of the independents were still recording the majority of their catalogues in the 78 rpm shellac format because they lacked the capital to upgrade their equipment. In addition, Billboard discontinued its charts monitoring jukebox play and sheet-music sales and stopped keeping separate charts for music sales and radio play. Instead, the magazine began publishing a combined chart, representing radio and sales, the "Hot Ioo" chart, after 1957. The new chart system made sales and radio broadcasts indistinguishable from one another. The jukeboxes, whose charts motivated radio stations to play certain songs because station owners believed this would help them capture the youth market, ${ }^{52}$ were rendered virtually inconsequential in 
shaping radio play from that point on. The independents that survived the recording format and chart format shift were those, such as Chicago's Chess, that were able to press records in all the formats, ensuring that they could reach any audience member regardless of equipment. ${ }^{53}$

Black radio programming seemed to mirror the rise and decline of the power of the independents. In 1955, when Muddy Waters was touring with Alan Freed's show, there were radio stations in thirty-nine states that reported broadcasting "Negro programming," which included news, sports, soap operas, public-service programs, and all forms of music. In 1956, when Nat "King" Cole was attacked in Birmingham, there were radio stations in forty-two states reporting "Negro programming." As the recording medium shifted to $45 \mathrm{~s}$ and then $33 \mathrm{I} / 3$, as top-forty formats took over, and as the Citizens' Councils' anger over the popularity of Black music increased, the number of states reporting "Negro programming" fell to thirty-eight in $1957 .{ }^{54}$ By I960, only twenty-five states had stations broadcasting "Negro programming." 55 In 1965, when there were approximately 19 million African Americans with an estimated buying power of $\$ 22$ billion annually, there were only twenty-eight states where radio broadcast Black content. ${ }^{56}$

The optimistic view of the changes in the number of stations broadcasting "Negro programming" might be that, because of the popularity of Black music and Black-derived music among white teenagers by the end of the 1950s, it was becoming impossible to discern the difference between "Negro programming" and the rest of the programming. In reality, at least in the reality created by broadcasters and advertisers, the Black audience and the white audience were two distinct groups. ${ }^{57}$ The Chicago Defender observed that broadcasters were trying to create a "separate but equal" industry in which the Black audience was understood to be working low-level jobs and devoid of diverse tastes in programming. ${ }^{58}$ The result of the limited play of Black programming by broadcasters meant that the diversity in Black music-for example, the Black classical tradition or the Black country-and-western tradition-were not part of the broadcast day. ${ }^{59}$ In addition, radio stations required that music producers force Black musicians to change the political messages in their songs. ${ }^{60}$ In the 1920 s and I930s, Black musicians lamented having limited access to recording and broadcasting. By the end of the 1950s, in those twenty-five states that played Black music, the musicians could reach a larger audience, but their popularity also introduced a new kind of cultural constraint. 


\section{THE IMPACT ON MUSICIANS}

Citizens' Councils and the music industry's attempts to control the spread and content of Black music had an enormous impact on musicians touring the South. Bandleader Buddy Holly, a native of Texas, was once asked how he could stand traveling and performing with Black musicians in the Alan Freed tours. Holly's response typified what the segregationists feared: "Oh we're Negroes too. We get to feeling that's what we are." Carl Perkins, the Tennessee-born guitarist, explained that the white musicians performing Black music had to contend with southern preachers who believed that the musicians were "defiling the minds of our beautiful teenagers." In the minds of white supremacists, these performers were race traitors who, along with the Black musicians, were the "shock troops of mongrelization." Perkins, for one, was aware of this danger. In the midI950s, he toured with Chuck Berry, the Coasters, the Drifters, Frankie Lymon, and Little Richard, among others. "I really was nervous about it," Perkins recalled, "I told my brother, 'We could get killed. . . W We're gonna be the next Nat "King" Cole. Somebody's gonna get us."'"61

The fear of "being the next Nat 'King' Cole" extended to Black musicians as well. For the touring musicians, harassment was a daily occurrence. The treatment of Black musicians in the South forced many musicians to refuse to tour the region. Nat "King" Cole summed up their experience by saying that the musicians, regardless of their fame and wealth, were forced to live as second-class citizens when on tour in the South. Muddy Waters and his band routinely had to go around to the back door of restaurants to buy food, and at gas stations they faced the threat of violence from groups of white men. Louis Jordan, who recorded in Chicago for Decca Records, and his band added to the list of daily abuses by explaining that they had to pay higher prices than whites for food and lodging. Mississippi-born and Chicago-raised, Sam Cooke and his band were once arrested in a whites-only park in Memphis. The arresting officers told them, "You are not in Chicago. We will hang you down here and they'll never find your body." ${ }^{\prime \prime 2}$ Needless to say, touring the South reinforced for many Black performers why they liked Chicago. Despite belonging to a segregated union, and though housing and employment were limited in Chicago, they did not have to regularly fear interactions at gas stations, parks, and restaurants. ${ }^{63}$ Integrated shows were rare. Black 
musicians performed mostly in bars that white teenagers could not enter. When integrated shows, which occurred because the white audience could travel the city freely even if the Black musicians could not play freely due to union rules, did occur in Chicago in the I950s, there were no riots or belligerent public outrage. ${ }^{64}$

The danger for the musicians increased when they performed for white or integrated audiences in the South. One persistent danger was the attention of white women. Having been born in the South, the musicians knew the danger of looking at white women. After the shows, white teenage girls swarmed the stage doors. This filled many Black performers with fear. Blues howler Wynonie Harris, who recorded for King Records in Cincinnati, recalled hiding in men's washrooms following shows to avoid white female fans. ${ }^{65}$

The threat of violence extended to broadcast venues that dared to feature Black artists. For instance, an Alabama television station planning to broadcast a live performance by singer Harry Belafonte was knocked off the air when a vigilante pulled down the cables at the transmitting tower. The vandalism occurred minutes prior to the broadcast. No one saw the performance. ${ }^{66}$

In addition to the hate groups and vandals, the police also targeted Black musicians. In Baton Rouge, rock and roll star Little Richard was arrested for "improper posturing." At the show, 400 teenagers were arrested under the same charge. All Little Richard, his band, and the audience had done was take part in a semi-integrated show. ${ }^{67}$ Dizzy Gillespie, Ella Fitzgerald, and her orchestra were all arrested in Houston. Empowered by the ban on offensive music, the police raided the club under the auspices of the city's blue laws. Finding no drugs or other illegal items, the police charged the jazz musicians with gambling (they were playing cards backstage before a performance). ${ }^{68}$ These examples of arrests and harassment of Black musicians demonstrate that the targets of white supremacists were not genre specific. White supremacists saw all Black musicians who performed for white or integrated audiences as a threat to segregation.

For Black musicians in the I950s, Chuck Berry became the chilling example of what could happen to a performer in the hands of the authorities. By 1958, Berry, who recorded for Chicago's Chess label, had eight songs on the top-roo pop charts and four best-selling rhythm and blues recordings. In addition, he opened an integrated nightclub in a white neigh- 
borhood in St. Louis_Club Bandstand. A year later, Berry was arrested for violating the Mann Act-a I920s federal law prohibiting the transportation of women across state lines with a sexual intent. ${ }^{69}$

The female in question was Janice Escalante-a fourteen-year-old with two prior convictions for prostitution. Escalante was a mixed-race woman Berry met while on tour in Mexico and the American Southwest. Escalante had joined Berry on tour and worked as a hat-check girl in Berry's club in St. Louis. When she was not on duty in Club Bandstand, she worked as a prostitute. When she was arrested for solicitation, she told the police how she had come to live in St. Louis. ${ }^{70}$

To the St. Louis authorities, Escalante presented an opportunity to destroy Berry, who had publicly violated numerous rules of segregation: he had frequent and well-known relationships with non-Black women, played before integrated audiences, and owned an integrated club. Not only was Escalante underage, but she had traveled with Berry across state lines and engaged in an intimate relationship with Berry. Escalante and Berry's relationship was a textbook Mann Act violation.

The Mann Act did not require that the parties involved have sex. All that was needed was proof of the intent. In addition, though conceived as an anti-white-slavery law, the Mann Act did not contain language that specifically made it illegal for Black men to transport non-Black women. However, throughout the history of the law, the Mann Act was used to punish Black men for engaging in consensual relationships with nonBlack women. This was the case with Chuck Berry. ${ }^{71}$

There were multiple Chuck Berry trials. The first resulted in a guilty verdict, which was overturned in an appeals court that ruled the judge had "intended to disparage the defendant by repeated questions about race." In addition to asking constant questions concerning race, the judge only referred to Berry as "the Negro." The second trial began following a I959 incident, in Mississippi, when Berry asked a white girl out on a date after one of his shows. He was arrested and served a brief jail sentence in Mississippi. The press coverage of this event gave federal authorities in St. Louis the motivation to retry Berry under the Mann Act. ${ }^{72}$

One outgrowth of the trials was that the southern press depicted Berry as a danger to social mores regarding race and sexual relations. To prove its case, the southern press published the trial testimony next to lyrics to Berry's hit song "Sweet Little Sixteen" (originally released in I958), which described a white teenage girl who wore a clingy dress, high heels, and too much makeup so that she could sneak into shows and dance with all the men. "Oh, but tomorrow morning," he sang, she would "change 
her trend" and leave the grown-up world behind as she returned to school. In the hands of his enemies, this song was not about a musician observing the change in audience but an indictment. ${ }^{73}$

Berry's second trial was lengthy. It ended with him being convicted and sentenced to three years in prison and a \$10,000 fine. The series of trials devastated his career. All of his songs written after the arrests and trials failed to sell. Chess was able to make some money from rereleases of Berry's I950s hits, all of which were covered by white British rock and roll bands like the Beatles, the Rolling Stones, and the Animals. ${ }^{74}$

Berry's story illustrates that in trying to answer Nathaniel Dett's call to emancipate Black music from the racist white imagination, Black musicians had disrupted the order of things. Rather than finding freedom from segregation, the growth in the popularity of their music transported the Black musicians into a world where the beating of Nat "King" Cole made real their worst fears regarding racial violence and oppression. Though Cole argued that there had been progress in race relations, many musicians, both Black and white, saw the attack as proof that little had changed.

The danger that the musicians faced continued into the I96os. For example, Sam Cooke had difficulty booking hotel rooms throughout the South in the early I960s. In I963, in Shreveport, Cooke was refused service at the city's Holiday Inn. Cooke argued with the proprietors. The dispute became heated and his band had to convince him to leave the hotel lobby out of fear that Cooke would get himself killed. After Cooke left the hotel, he drove through the city, in his Maserati, hand on the car's horn. The police arrested him for disturbing the peace. He bailed himself out in time to perform that night. A few weeks after the incident, Cooke wrote the civil-rights anthem "A Change is Gonna Come." 75

The song began with the line, "I was born by a river in a little tent." With the image of the river, Cooke was calling on the countless metaphors of restlessness and migration that filled gospel and blues lyrics, and echoed through the works of poet Langston Hughes. The imagery of the lyric also called into play the theme of being a "motherless child," a key metaphor in the Black music tradition for understanding the African American experience. Cooke captured the pain of being rootless, something a Black musician understood all too well, by writing, "Oh And just like the river / I've been running ever since."

Fueled by his experiences touring the South and the conversations he had with students who participated in sit-in protests, Cooke used the song to capture the desperation of someone suffering racial oppression 
by writing, "It's been too hard living but I'm afraid to die." The next line suggests that the racial oppression was causing the former gospel singer a degree of religious crisis, "'Cause I don't know what's up there beyond the sky." He challenged the tradition of white-only spaces in the lines, "I go to the movies and I go downtown/ Somebody keep telling me, 'Don't hang around.'" "Then I go to my brother," he wrote, "And I say, 'Brother, help me please,'/ But he winds up knocking me down on my knees." In the last stanza, Cooke turned the song toward the hope that Martin Luther King Jr. spoke of by writing, "Oh there been times that I thought I couldn't last for long / But now I think I'm able to carry on/ It's been a long, a long time coming / But I know a change gonna come, oh yes it will." ${ }^{176}$

Cooke was right: there were changes at hand. The growth in their popularity and their cultural power were indications of how much Black musicians, and their position in society, had changed. In previous decades, when threatened with racial violence, many would have run away. ${ }^{77}$ The musicians in the I950s and early I960s had started standing their ground and discovered that by doing so they could weaken segregation and disrupt the music industry's race-based economics.

Sam Cooke, Nat "King" Cole, Chuck Berry, Muddy Waters, Wynonie Harris, and the other performers touring the South and changing radio had something in common: they were all headliners. They were famous. Their fight against segregation took place outside of the Black community and gained part of its power from changing the perception of race among white youth. For those musicians who were not famous-the working musicians, the guys in the band-the fight against segregation assumed a different form. For them, the discussion of segregation took place not in teenagers' bedrooms or in integrated clubs, but in the American Federation of Musicians' union halls and within the Black public sphere in Chicago. 
CHAPTER 5

\section{Dissonance and the Desegregation of Chicago's Musicians' Union, 1963-1967}

In February 1963, violinist Carol Anderson, a twenty-three-

year old graduate of the Boston Conservatory of Music and a social worker in Chicago, sat in with the violin section of the symphony orchestra in Oak Park-an affluent white suburb of Chicago with a total population of 60,000-less than Ioo of whom were African American. ${ }^{1}$ The symphony conductor, Milton Preves, having worked with Anderson in Chicago, was eager to have her part of the Oak Park orchestra. Later that day, Anderson received a phone call from the chairwoman of the symphony board, Mrs. Palmer, who explained to Anderson that she would not need to return for future rehearsals. The reason for the rejection was that Carol Anderson was African American. ${ }^{2}$

Mrs. Palmer explained the board's decision to the local papers by saying, "We just thought that we were not the organization to crusade and pioneer a controversial subject in the community." According to Mrs. Palmer, the symphony would not consider integration until there was a "consensus of the community . . . in favor of that." ${ }^{3}$ In the scandal that followed the rejection of Anderson by the symphony board, Preves, the symphony's conductor, resigned in protest of the whites-only policy. One fifth of the seventy-five-member orchestra also walked out in protest. ${ }^{4}$

According to newspapers at the time, community leaders responded in a similar manner. The local Methodist pastor demanded that his congregation "help the board correct this grave error at once by demonstrating to them and to our larger metropolitan area that we have advanced beyond this narrow line of prejudice." The congregation responded by calling and harassing the symphony board and insisting that it wanted performers 
"selected on the basis of ability rather than the color of their skin." The pastor made it clear that "this is not a crusade to integrate our symphony orchestra; this is an appeal to let the board know that the people of this community want the best music performed without any reference to the color of their skin." 5

For the African American community in and around Chicago reading about her, Anderson's rejection was a reminder of the extent to which segregation limited their lives. The Chicago Defender likened the incident to the rejection of Marian Anderson, the famed African American singer, whom the Daughters of the American Revolution (DAR), barred from performing in Constitution Hall in I939. In addition, the African American community in Chicago in I963 was protesting against segregation in the public schools and in housing. ${ }^{6}$ Both examples of segregation existed despite the fact that the Supreme Court had found racial covenants illegal in I948 and school segregation illegal in I954. Though I963 was the centennial of the Emancipation Proclamation, almost thirty years had passed since the DAR rejected Marian Anderson, and there had been clear victories in the Supreme Court, it appeared to many African Americans in Chicago that little had changed. ${ }^{7}$

The newspaper coverage of Carol Anderson's rejection and the reaction of certain segments of the Oak Park community humiliated the symphony board. The board begged Preves to take back his job. Preves refused. It begged Anderson to perform with the symphony. Anderson agreed, but only for one performance and only if Preves conducted. ${ }^{8}$ For the début and farewell of Carol Anderson in Oak Park, the orchestra played "Pathétique" by Tchaikovsky. 750 people attended the concert and cheered Anderson's performance. Mrs. Palmer, who was the orchestra's principle cellist, did not attend the concert. When the performance was over both Anderson and Preves refused to take permanent positions with the organization. They both felt that, although the symphony board had retreated from its position, it had not changed its beliefs. ${ }^{9}$

Though it may not have seemed that way to African Americans living in Chicago at the time, Carol Anderson's performance in Oak Park was a sign that there had been a change. First, the orchestra conductor and several of the musicians, all of whom were white, stood by Anderson. Second, members of the local community demanded that Anderson be considered on the grounds of merit rather than race. Finally, the symphony board had to back down because of public outrage, which was an uncommon event 
in the history of musicians in Chicago. These changes could be attributed to the successes of the civil rights movement. Perhaps equally important to reshaping white attitudes was that Black musicians had fought for and won recording contracts, and radio and television appearances, and were regularly performing before white and integrated audiences. ${ }^{10}$ All of these achievements had been dreams to Nathaniel Dett and the other Black musicians in Chicago since the early twentieth century.

Despite these successes, musicians in Chicago, as Carol Anderson demonstrated, were far from emancipated. It was difficult for them to find work north of 22nd Street in I963. They were not employed at white-run radio stations or in Chicago's Symphony Orchestra. One reason was that the power of the segregated American Federation of Musicians to buttress discriminatory practices still existed.

For many African American musicians in Chicago, the rejection of Carol Anderson provided the impetus to take a public stand against the segregated union. The disgruntled musicians had been holding informal meetings since December 1962 in bandleader Red Saunders's house in the Woodlawn neighborhood on the South Side. Carol Anderson's experience prompted them to move their meetings from the living room to the union halls. ${ }^{11}$ The decision to oppose the union was a perilous one for these musicians. In choosing to directly contest segregation, they were also threatening to destabilize the autonomous Black cultural sphere, which since the I920s and I930s had defied white control of the city.

The musicians wishing to end segregation had opponents in Black union Local 208. Among them were the local's leaders Harry Gray, Charles Elgar, and Walter Dyett. These three men embodied the idea born in the early twentieth century that separate Black institutions were an attribute and a necessity to building Chicago's Black community in the face of white oppression. At the time of the revolt, Harry Gray had been president of the local for nearly forty years. ${ }^{12}$ Walter Dyett, one of the most outspoken of the leaders of Local 208, built his career as the bandleader for the I84th Field Artillery Band and as a music teacher in the city's most prominent Black high school, DuSable. In this capacity, he trained most of the city's musicians, including many of the musicians who joined with Red Saunders. ${ }^{13}$ The third member of the board, Charles Elgar, was born in New Orleans in 1879 and began working in Chicago in I903. He contributed to the building of the musicians' union local and the migration network by actively recruiting other musicians to move from New Orleans 
to Chicago. ${ }^{14}$ By the early 1960s, Elgar was a music teacher and a mentor to younger musicians, and performed regularly in the public schools. ${ }^{15}$

In these three examples there is a wealth of information regarding the leadership of Local 208. First, they were from an older generation of musicians. Elgar was one of the local's first members. Gray and Dyett represented only the second generation of Local 208 leadership. In short, they had lived all of the union history with Local ro and segregation, whereas Red Saunders's fellows represented a cross section of musicians in regard to age, migration pattern, the methods by which they learned music, and the genre they played. The historical memory of Saunders's group also differed from that of Local 208 leaders. They knew the history of segregation, but they had not lived it in the same way or as extensively as the leaders of Local 208 did. Nor did they have to build a professional organization in the face of segregation. Saunders's group and the local's leaders did have one thing in common: they were men. Black women made up less than 7 percent of the Black local. Even though Carol Anderson's travails motivated Saunders's group, women, with the exception of one female white board member, were not sought out for their leadership on any side of the debate.

Through the course of the debate, it became apparent that within the two groups of African Americans there were different ideas concerning segregation. The leaders of the dissidents sought and found support in the major integrationist organizations of the early I $9605 .{ }^{16}$ The dissidents also had a historical advantage: they staged their demand for membership in the white local in 1963, during the Emancipation Proclamation's centennial. In their pamphlets and rallies they made use of language from the March on Washington, held that same summer. This allowed them to see their movement as part of the broader civil rights movement to "correct the old evils of segregation and discrimination ... currently sweeping the entire nation. . . ."17

The Local 208 leaders occupied a different place in the spectrum of African American activism and history. It should not be forgotten that the majority of the Black local's leaders were born in the late nineteenth century; they migrated from the South for jobs and to escape southern racism and racial violence, and in Chicago they found an affluent Black middle class that had built an independent community. As leaders, they modeled themselves on this middle class. This is why their union seemed to have one foot standing atop the writings of Booker T. Washington, who in the I89os promoted racial consciousness as a 
means of creating economic independence and solidarity of the Black middle class. Meanwhile, the Black union local had its other foot firmly planted in the radical beliefs of W.E.B. Du Bois, who in the I93os demanded that African Americans boycott businesses that did not employ Blacks because he believed that political agitation was the way to guarantee economic rights. ${ }^{18}$ The Black local combined the seemingly disparate philosophies of Washington and Du Bois because neither philosophy alone could adequately address the real-world needs of Chicago's musicians. Their thinking regarding race and labor speaks to the multifaceted nature of the identities they constructed through the union. No simplistic definition driven by affiliation with a social, ethnic, religious, linguistic, political, or economic group determined their, or their opposition's, behavior. ${ }^{19}$

Because of its history of self-sufficiency and autonomy, Local 208 had a great deal more in common with Black fraternal and benevolent societies in Chicago and the welfare capitalist tradition prior to the $\mathrm{I}_{94 \mathrm{OS}^{20}}$ than with the white American Federation of Musicians local. The development of clubs-such as the YMCA, and organizations-such as the Urban League, was a defining characteristic of the Black public sphere. The community had to develop autonomous institutions in the early twentieth century because African Americans were refused membership in existing institutions. For example, Local 208 owned a credit union for its members, a union building that had rehearsal space for members, and a musicians-only apartment building, which were benefits that the members of the white local did not have. Social-welfare benefits were important because landlords often refused to rent to musicians. ${ }^{21}$ Bank accounts and retirement plans were hard to come by because the Black musician's life was often transient and unstable-so much so that Local 208 union cards, unlike those of the white local, did not list the member's address or phone number. ${ }^{22}$ Such benefit programs and policies were symbolic of how different the two locals were in terms of leadership and their roles were in the lives of their members.

The leaders of the Black local were also different from the most prominent labor leaders in Chicago at the time. As labor organizers, they came to power at the same time that Chicago labor leader A. Philip Randolph, of the Brotherhood of Sleeping Car Porters, was warning against dependence on white institutions and white patronage. However, a gap began to form between the strategies of Local 208 and other Black labor groups in the I930s with the emergence of the Congress of Industrial Organiza- 
tions (CIO). In the I930s, the $\mathrm{CIO}$ was a new and radical association that believed the labor movement would find success only if white, Black, and Hispanic workers unified. The CIO needed Black labor if the organization was to prevail in the life-and-death struggle that was labor politics in cities like Chicago in the first half of the twentieth century. ${ }^{23}$ In I940s Chicago, the coalition resulted in the desegregation of public transit jobs. ${ }^{24}$ The recognition of the importance of integration and the power of Black labor transformed leaders such as Randolph into nationally recognized figures with the cachet needed to force Franklin Roosevelt to desegregate the defense industry. ${ }^{25}$

In the first half of the twentieth century, the leaders of Local 208 had no such value to the American Federation of Musicians, which was affiliated with the more segregationist American Federation of Labor (AFL). While other Black labor leaders, including Randolph, moved toward seeing integration as a necessity, the leaders of Local 208 continued to build a separate institution devoted to the development of an autonomous labor force. They had reason to feel this way because, even after the CIO and AFL merged in the I950s, the American Federation of Musicians continued to support segregated locals. Following the merger, James Petrillo, the president of Chicago's white local and of the executive board of the American Federation of Musicians, was elected to the executive board of the AFL-CIO. ${ }^{26}$ Petrillo's continued position of power was the ultimate sign that Black labor rights were not a priority within the union.

In the musicians' union, both the Black integrationists and the Black separatists wanted equality. The difference between the two groups of labor leaders was that one believed integration and equality were possible. The other group, which included Local 208, felt more skeptical of a coalition with whites.

Furthermore, the development of the Black local paralleled the rise of the modern ghetto in Chicago from the I930s through the I96os. Living in a racially segregated and economically deprived part of the city, the Black local's leaders, as well as many of the local's members, began to form a Black ethos that was an expression of the ways in which Black Chicago had urbanized in a divergent way from white Chicago. Being separate from white Chicago contributed to the formation of the Black local's intellectual genealogy of protest through self-sufficiency. The intellectual history of the leaders of Local 208 was the same history that formed and informed protest at the street level in Chicago among community groups and youth gangs, who in 1963 were demanding better school facilities 
and the establishment of Black studies classes. ${ }^{27}$ The same history underscored the work of Chicago's Elijah Muhammad, Fred Hampton, and a young Malcolm X. Like the Black local, all these men were shaped by the Chicago experience and sought to build independent Black institutions because they believed that equality in a world dominated by whites was a delusive possibility. ${ }^{28}$

Therefore, life in segregated Chicago had politicized Saunders's group and the local's leaders in different ways. Their lives stand as an example of how individuals recombined their various identities in ways that led them to assume new types of collective action..$^{29}$ The union leaders believed that in pushing for segregation, whites had inadvertently forced the creation of Black spaces-nightclubs, schools, barbershops, and so forth—that fostered the development of community identities and cultures..$^{30}$ In a sense they understood themselves and their union through the lens of the Black public sphere. As they saw it, they were contributing to and being formed by a broadly conceived social and cultural history of politics operating in terms of a specific spatial setting. ${ }^{31}$ In arguing that African Americans gained strength from these spaces, the union leaders were also contending that integration threatened to be a new form of oppression that would reduce Black representation in the union and erase Black community identity. ${ }^{32}$ The pro-autonomy position held by the Black union leaders stood in striking contrast to that held by Saunders and the other dissidents who believed that an all-Black leadership could be as dissatisfying as an all-white leadership. For these musicians, merging the locals would bring equality to the city and greater economic self-determination for all Black musicians.

The debate over integration of the union cannot be understood apart from the history of how the leaders of Local 208 , who in the early twentieth century helped to establish the Black cultural sphere on the South Side as a way of resisting white oppression, came into conflict with a direct-action collective seizing on the advances of the civil rights movement. This debate illustrates that Black musicians were far from being passive unionists easily manipulated by white exclusionary politics. Rather, they represented varying strategies and responses to the difficulty of negotiating and surviving racism in Chicago. ${ }^{33}$ Though one group supported autonomy and the other wanted immediate and total integration, it would be a mistake to view this history in terms of heroes and villains. Rather, the two groups represented the complexities of the African American response to racism in Chicago from 1902, when the Black local formed, through the early i96os. 
Though Red Saunders, seizing on the treatment of Carol Anderson, may have forced the debate into the public eye, as the conflict played out, it would not be Red Saunders and his fellows that ultimately represented Black musicians in the merger. Instead, the "old men" of Local 208's board represented the 1,700 Black union musicians. The Black union leaders would have to contend with the white union leadership and try to ensure that the musicians' union would achieve not only integration but also equality. Having spent sixty years standing their ground against white segregationists, the Black union leaders found themselves, because of the actions of the dissident musicians, finally debating segregation with the white union leadership. The ensuing labor fight was a contest for the authorship of integration, and it called into question all that Chicago's Black musicians' community had built.

\section{CREATING A GRASSROOTS MOVEMENT}

Red Saunders was a man raised in a segregated world. Born in Memphis in I9I2, he moved with his five siblings to Chicago in I923 following the death of his mother and abandonment by his father. His oldest sister had friends in Chicago-Lil and Louis Armstrong-with whom the family stayed upon their arrival in the city. The segregation and economics of Chicago's South Side in the I920s necessitated that Saunders's sister pass for white in order to find a job that paid enough to support her and the younger children. ${ }^{34}$

Saunders and his sister had similar complexions. Had he wanted to, he could have passed for white as well. Saunders's choice to be a Black musician suggests that in the I920s and I930s, there were more economic opportunities for Black musicians in Chicago than there were for a single Black woman trying to raise a family. Moreover, knowing Louis Armstrong for nearly all of his life connected Saunders to the musicians' community, and helped him and his siblings survive the migration to Chicago from the South. The story of Saunders's youth illustrates the power and cohesiveness of the Black public sphere on the South Side in the early twentieth century. Yet in 1962, Saunders was working to integrate the musicians' union, an action that threatened to destabilize the Black public sphere and the musicians' community. Something had clearly changed for Saunders.

Being a musician in Chicago meant that Saunders would have found it difficult to play a union job beyond the limits of the South Side. It also 
meant that he could not hire white musicians to play in his orchestra because that would have broken union rules. Saunders did break this rule to accommodate Josephine Baker. In I960, Baker performed at Chicago's Club DeLisa. As the orchestra leader, a position he had held since the late I930s, Saunders had to hire musicians who could play Baker's arrangements, which required that Saunders hire accordion and violin players. He could find African American violinists on the South Side, but the accordion was not a prominent African American instrument in Chicago. White accordion players demanded that Saunders pay the white local's pay scale, which was higher than the Black local's scale. Saunders paid. By doing so, he violated the Black local's rules and was called before the board to defend himself. The experience of the hearings led him to seriously contemplate desegregating the union. ${ }^{35}$

Saunders initiated the dissident movement in the early I960s by quietly approaching musicians backstage. He would whisper something like, "How do you feel about the all Negro Union?" If the musicians expressed dissatisfaction with the union, he invited them to the secret meetings held on each Sunday afternoon in his living room. ${ }^{36}$ The first meeting was in December 1962 and thereafter occurred once a week. Saunders, as bandleader transformed into labor leader, was responsible for emboldening the other musicians and convincing them to proceed quietly until the appropriate time to make their move. At these meetings, he never mentioned his own problems with the union, nor did he mention what had transpired at his closed-door punitive hearings with the local's board. ${ }^{37}$

As it turned out, it was not that hard for Saunders to find other disgruntled musicians. For decades, the musicians of Local 208 had been dissatisfied with their work conditions and they had amassed a long list of grievances. They knew that the white local, Local Io, paid twice as much in death benefits as the Black local did and they knew that the dues of the Black local were higher than the white local. ${ }^{38}$ Furthermore, the discontented musicians believed that the Black local's leadership was corrupt in that the leaders only gave jobs to their friends. ${ }^{39}$ The fact that they were not offered jobs outside of the South Side and that the union's national conventions were always held in southern cities, with dehumanizing racial traditions, made the union's support of segregation obvious. ${ }^{40}$ Adding to the problems was the leadership of the Black local, whom they had seen side with club owners over musicians in disputes. Then there was the problem of the national union's white leadership, who in I944 
had claimed that segregated locals were "entirely satisfactory to the colored membership." ${ }^{\prime 11}$ The members of Black Local 208 were also aware that the one previous Black-led attempt to merge the Chicago locals, in the I930s, had failed. ${ }^{42}$

However, times were changing. The other major union cities, such as Los Angeles and Denver, had already integrated their locals by I962. Chicago was the last holdout. This was ironic because Chicago was also the first major city to have segregated locals. For those dissatisfied with the segregated union, I962 presented an historic opportunity. James Petrillo, who had reigned as the president of the white local since the I920s and opposed desegregation, had been voted out of office. Replacing him was a group of younger leaders whom the Black dissidents hoped would be more amenable to integration. ${ }^{43}$

Given the situation, it was not hard to find musicians interested in talking about desegregation. Finding musicians willing to go against white union leaders as well as the Black union leaders was a different story. To overcome the fear of opposing the union leadership, Saunders-who, believing himself to be a dissident, had met briefly to discuss how to create a social movement with community leaders associated with The Woodlawn Organization, a protest group taught by Saul Alinsky ${ }^{44}$-realized he had to use the connections between bandleaders and orchestras. Saunders began by approaching his own orchestra members and then other bandleaders, such as William "Lefty" Bates, who then spread the movement among their bandmates. The result was a group of musicians that illustrated the diversity among musicians in Chicago, as well as refuted any argument that this was a movement solely of younger musicians or musicians of only one genre. ${ }^{45}$ The members of the dissident movement spanned generations, migration patterns, genres, and competing music theories. Even the ways they had learned music was different. Some of the members were street trained, others had learned from recordings, and still others learned in school and military bands. What all of them had in common was that, with the exception of Saunders and Bates, they were not headliners or stars. The majority of those who joined were not able to use fame to cushion the impact of segregation on their careers. Rather, they were the workingmen of the musician world, a faction of sidemen, fighting for the right to make a better living.

The dissidents had a difficult task before them. Though a large number of Black musicians were not happy about segregation in the union, those who were willing to come forward and protest were in the minority. ${ }^{46}$ 
Being Black musicians did not make them radicals. Choosing to oppose institutional segregation openly and risk their careers did. The fear of being known dissidents was the first obstacle they had to overcome. Then, they had to accept that they were questioning the mandate of the Black union leaders. Finally, they had to develop a protest style and rhetoric that could challenge both the union's formal and informal methods of control.

The Black local was a bureaucratic organization that relied on written forms of communication and control while simultaneously maintaining the informal cliques that constituted the union's leadership. Essentially, the union worked to formalize status and employment by defining jobs, contract parameters, and wage scales. Union membership was one of the key components to understanding oneself as a professional musician rather than as an amateur, which meant that the union exercised a great deal of control over the social standing of the musicians. The amount of bureaucratic control in the hands of the union board often put musicians at a disadvantage in disputes over contracts and pay between musicians and venue owners. Businessmen could wait for union decisions, but the musician could not wait because it meant lost pay. In filing a complaint, a musician risked the possibility of not being hired for future jobs, and the possibility of becoming known as a troublemaker. ${ }^{47}$

The informal superstructure of "old men," as the local's membership called them, controlled everything. In both the white local and the Black local, the power of the old men was an accepted fact, as was the possibility that a musician could starve to death waiting for the settlement of disputes. Younger musicians, in both the white and Black locals, felt that they were at a disadvantage in this system because the control of both the formal and informal parts of the union was in the hands of the same clique. Challenging this group and failing would mean that all the musicians involved with the insurrection would be purged from the union and stripped of their identities as professional musicians. ${ }^{48}$

As Saunders and his fellows proceeded in their plan of attack, they focused on the union itself rather than picketing businesses that did not hire Black musicians. By presenting the union as the problem, they could argue that outsiders-namely, the union leaders-were controlling the Black musician's economic destiny. In focusing on the union, they identified the problem as being the reinforcement of institutional segregation by a network of leaders whose power was contingent upon the continuation of segregation. The dissident's strategy for dismantling this situation was to destroy the mythology that said Black musicians were satisfied 
with segregation and with dependency on union leadership for jobs. Questioning and dismantling the segregated structure of the musicians' union became their end goal.

\section{THE REVOLT}

Through the winter of I962 and I963, Saunders's group quietly amassed members. Then it staged a public protest that would purposefully shock the Black union local's leaders, who were accustomed to facing little or no organized resistance from the musicians. The existence of a radical group of Black musicians became apparent to all of Chicago on March 20, I963, when Saunders's group, motivated by the treatment of Carol Anderson, marched into the white local's headquarters and demanded membership. The leaders of the white local were advised by their attorneys that, according to the bylaws of the union and the growing number of civil-rights laws and lawsuits, they had to accept the Black members. "200 Musicians Revolt, Join Mixed Union," announced the headline on the front page of the Chicago Defender. ${ }^{49}$ While the enraged leaders of the Black union local called them "dissidents," and the Chicago papers described them as a "rebel faction" of musicians, the 200 called themselves the Chicago Musicians for Harmonious Integration. At the time, they represented less than Io percent of the Black local's membership. However, a week after the initial protest, eighty-four more Black musicians defected to the white local. This pattern continued throughout the summer and into the fall of $1963 .{ }^{50}$

There was an immediate cost to forcing integration. After the dissidents went public with their protests, the leaders of Local 208 demonstrated their power over the musicians by firing the dissidents' wives who did office work for the local. They refused membership applications from the dissidents' relatives and removed the dissidents from the membership rolls of the local, which destroyed the musicians' seniority and eliminated the possibility of a death-benefit payment. In addition, after the existence of the dissident movement became apparent, they began receiving death threats. The retaliation against the integrationists suggested that even though it was a Black-led union local, the leaders were not opposed to using Chicago-style tactics in an attempt to maintain power. ${ }^{51}$

Following the seemingly spontaneous protest of March 20, the Chicago Musicians for Harmonious Integration had two goals. First, they needed 
to make their movement sustainable. Second, they wanted to dominate the voting at Local 208's annual meeting in September I963. Both of these goals required that they build membership and dismantle the culture of fear that kept Black musicians from challenging their union leadership.

The Chicago Musicians for Harmonious Integration had a problem: many of the group's members, including Saunders, were undereducated, or had a low level of literacy. If they were going to oppose the union, reach younger musicians, and use the media effectively, their word-of-mouth campaign would have to shift to written forms of protest. Saunders solved this problem by relying on two younger members of his protest group, drummer Charles Walton and flautist James Mack, both of whom were in their late twenties, university trained, and teaching in the city's public colleges. Following the March protest, they began creating letters and pamphlets that the dissidents sent to Local 208 members and the local media. $^{52}$

In these letters, the Chicago Musicians for Harmonious Integration presented the argument that the musicians were in a "position" to correct the "evils of Local 208" and obtain membership in a "larger, more progressive, more prosperous local. ..." They contended, "There is no room for segregation among musicians in Chicago. Those of us who have joined Local ro have already started to participate in the benefits. . ." They recommended that anyone doubting this should talk to one of the "more than 200 members of the Local 208 who also belong to Local Io." After all, the 200 were among the "most working musicians in the city. . ." James Mack also informed the newspapers that Local 208 took dues but provided no services and did nothing about the proliferation of "record spinners in clubs who . . . are putting musicians out of work." They accused the leaders of Local 208 of "running the Local for the benefit of themselves and a 'few cronies.'" 153

In the fall of 1963, the dissidents switched from the small meetings, and mailings, to holding large rallies where they could organize a force to pack the Local 208 annual meeting held on October 6, I963. Approximately 400 musicians attended the rallies, which was impressive given the fact that the Black local had I,700 members. This illustrates that the number of dissidents had doubled since March I963. Still the dissidents did not, and never would, become a majority among the membership of the Black local, though they may have been the majority of engaged members. At the rallies, James Mack emerged as the spokesman for the Chicago Musicians for Harmonious Integration. Arguing against separate locals, Mack 
contended, "Black representation is not necessarily good representation, not only in this local but sometimes in the Board of Education, the City Council and the United States Congress." ${ }^{154}$

The conflict between the local's leaders and the dissidents came to a head at the annual meeting of Local 208 when the dissident spokesmenMorris Ellis, Thomas Rigsby, Lefty Bates, Charles Walton, and James Mack-demanded that the regular order of business be suspended and that all present listen to their resolution. ${ }^{55}$ The resolution began by declaring that the "arbitrary division along racial lines of the brotherhood of professional musicians in this jurisdiction is mutually harmful to both Local 208 and Local $\mathrm{IO}^{\prime \prime 56}$ and ended by demanding that a merger take place within ten days of the vote. ${ }^{57}$

Local 208 leadership declared the resolution "unfavorable" and decided to hold a secret ballot right then and there. The ballot asked the members to choose between "I am against a merger of Local 208 with Local Iо" or "I am for a merger of Local 208 with Local Io, but only on terms which the officers of Local 208 think are fair to the membership of Local 208 and which are approved by said membership." The leadership wrote the language of the ballot and determined it "conclusive on the question and binding." Of course, no matter what the vote, the union leaders would maintain their power, and there was the possibility there would never be a merger. The plebiscite showed 283 votes for the merger, 43 votes against the merger, and 19 votes spoiled. ${ }^{58}$

\section{THE OTHER SIDE: THE LEADERS OF THE 208}

What transpired at the annual meeting illustrated that there were divisions within Local 208 concerning integration. While the dissidents exemplified the growing feelings of resentment and dejection many felt toward the union system, the Local 208 leaders represented the other side. They believed that by building up the power of Local 208 they were ensuring the musicians' right to work and standard of living. For example, Gray, the local's president, had persuaded the DeLisa family to double the pay of Saunders's orchestra in I937. When the family refused, Gray went to their offices and argued with them until they doubled the pay and gave each member of the orchestra five extra dollars a week. ${ }^{59}$ The Black union leaders felt that the only way to safeguard these basic rights and effective level of representation was by maintaining an autonomous local. 
The two factions saw segregation, resistance, and the history of the local in contrasting terms. For example, the leaders of Local 208 placed greater emphasis on race solidarity than on class solidarity. In looking at the union through this light, the local's leaders saw the events beginning in March I963 as a "raid" perpetrated on their local by the new regime of white union leaders. They saw the dissidents as compromising the strength of the Black musician community when they broke ranks and "defected" to the white local.

There was no evidence that the white local's leaders initiated a raid. Nevertheless, the lack of evidence did not stop the Black leaders from distrusting the white leaders. Many of the white leaders had come to power in late 1962 when they drove Petrillo and his allies out of office. From the perspective of the Black local's leaders, the white local's board was inexperienced and unpredictable. The Black leaders demanded that the union's executive board appoint Petrillo as the moderator for the merger talks. The executive board refused. At first glance, it would appear that they were calling on the engineer of segregation to also engineer the integration. Certainly, the dissidents saw it that way. The rank and file of the Black local had always thought that Gray and Petrillo had a backroom deal regarding the segregation of the local and the request that Petrillo be brought into the merger discussions seemed to confirm the rumor. However, Petrillo was the white leader with whom the Black union board members were accustomed to dealing. When facing the loss of the Black local, the Black leaders preferred the white leader they knew to the white leaders they did not know. ${ }^{60}$

Among Black musicians, there were many who supported the Local 208 leaders, such as saxophonist James Ellis, whose brother Morris was one of the "defectors." James Ellis voiced his skepticism of Black musicians having power in a merged union when he asked, "What chance will there be of electing a Negro president of the combined locals?" Jazz trumpeter Robert Schoffner agreed, saying, "Local Io is not interested in Negro members. They are interested in Negro assets. ... Why don't [the A.F.M.] force the local Io to merge with us?" Schoffner made this argument on the basis that Local 208 had always been integrated since Black musicians accepted white musicians who sought work in the Black combos. He saw the "defectors" who were unwilling to throw their support behind Local 208 as traitors. ${ }^{61}$

The leaders of Local 208 also found support from the Woodlawn Booster-a community paper representing the Woodlawn neighborhood, 
where many of the musicians lived. The Woodlawn Booster's editors supported the idea that "integration defeats its purpose if Negroes are merely swallowed up in the whole, all present identity destroyed without full identification with the whole immediately ensuing." The editors believed it was time to end segregation in trade unions and in "every area of American life," but they urged that rather than judging integration by its ends union leaders should focus on creating a "clear beginning. ... That is, it is not enough to merely accept Negroes into membership under the circumstances prevailing in the musicians union." "Whatever leadership and power Negroes have managed to develop," the Woodlawn Booster argued, "should be enhanced rather than destroyed if integration is to prove more than an imposter." "True integration," the paper suggested, "would seem more likely under the leadership of the Local 208 rather than the Local Iо." ${ }^{\prime \prime 2}$

The community support for the leaders of the Black local illustrates another division between those pushing for integration and those resisting it. Saunders's group understood and promoted the short-term gains of integrating, such as a higher pay scale and the potential for working throughout the city. They also knew that the times had changed and that it would be impossible to maintain union segregation in the future. By contrast, the leaders of the Black local and their supporters' point of argument emphasized the long-term consequences of destroying the local, and permanently damaging the Black public sphere. For them the cost of integration, such as the loss of community and self-determination, was too high. Even more so, they were beginning to acknowledge the painful reality that the existence of so many dissidents meant that they, the Black union leaders, could no longer argue there was only one Black community.

\section{THE MERGER: A FIGHT FOR AUTHORSHIP OF INTEGRATION}

Despite the best efforts of the Chicago Musicians for Harmonious Integration, they were not present at the merger negotiations. Instead, the Local 208 board represented African American musicians. As they began the talks with Local Io in late October 1963, Local 208 leaders were angry and ready to resist the white leaders. For them, this was a historic moment because the merger meetings represented the first time they had ever been invited by the union or any other segregated institution to a 
meeting to discuss such matters. They wanted to take advantage of the situation by demanding written protections against discrimination, "a merger of equals," a focus on employment rights, and guarantees of representation. ${ }^{63}$

Sitting across the table from the Black union leaders was the board of Local ı. A portion of the board, including president Bernard Richards, a jazz bandleader from Evanston, had defeated longtime president James Petrillo the previous year. The new board members, who ran against Petrillo because they believed he was paid too much and did not work to develop social benefits for members, were eager to use the merger debate to prove they could lead Local Io as effectively as Petrillo had. In March I963, they had accepted the 200 Black musicians on their attorney's recommendation. In the following months, they seized on the dissident movement as a way to embarrass the Black union leaders by continually suggesting to the press that the white local was the local of racial equality and the Black local was the bulwark of racism. The white leaders worked to prove that they were supporters of integration by taking on Red Saunders, and his second in command, Leon Washington, as informal advisers to the local's board on race issues. Therefore, in October 1963, when the merger talks began, the white union's leaders came to the merger table having won the public-relations battle. They also intended to also win the merger. ${ }^{64}$

Early in the discussions, the leaders from Local 208 presented a resolution that, among other things, insisted that a clause be written into the combined local's bylaws prohibiting discrimination. The issue of discrimination became the primary topic of discussion and haunted all the subsequent meetings because at its core there were grave differences in how the two groups experienced race and how they defined discrimination. ${ }^{65}$ Specifically, Local 208 demanded that there be guarantees that the members of Local 208 be given full membership rights rather than being held as new members, which would have subjected Black musicians to a loss of seniority and death-benefit privileges. Also, they would have been liable to the standard new member probation, which would have prevented the Black musicians from working in the city. In addition, the Black leaders wanted the board of directors and the other union committees to have a guaranteed position for a Black member. They worried that their members would be lost in the combined local because they would be a minority. The question of representation extended to the trial committee because it would be in the committee that issues regarding discrimina- 
tion would be heard and ruled on by the union. The importance they placed on representation, in combination with their fears of possible discrimination within the white union, led the Local 208 leaders to demand that there be an oversight board in place composed of non-AFM members. All of their demands would require that the bylaws of the union be rewritten to among other things, prohibit discrimination. ${ }^{66}$

The Local ro leadership rejected all of these proposals. They believed that the Local 208 board was simply trying to protect its power base by insisting on a mandatory board position for themselves-an accusation that ignored the fact that the Black leaders wanted elections to be held, which meant they were willing to risk their positions for the sake of Black representation. The white leaders replied to the request by offering severance pay and lifetime membership to the Local 208 board. As for the issue of the bylaws, Local io argued that no ban on discrimination clause could be added because discrimination could never be defined. What followed was a bitter discussion in which Local 208 attempted to explain discrimination. ${ }^{67}$

The leaders of Local 208 were "fearful of discrimination against the Negro musicians in this joined union and fearful of unfair representation of the Negro musicians ..." because they knew the AFM's history of racism and believed that only an African American would, or could, defend the rights of Local 208 members. "The fact still remains," contended Everett Samuels, the recording secretary of Local 208, "we are Negroes. . . Being Negroes we are fully cognizant of all pitfalls we must try to avoid." 68

Local 208's leadership was suggesting that guaranteed Black representation was the only way to prevent discrimination as well as the "swallowing" up of Black members by Local Io. If they were subsumed by Local Io, then, according to the 208 leaders, this would guarantee that the former Local 208 members would lose their history, distinctiveness, and voice in the union. ${ }^{69}$

To demand absolute equality and singularity at the same time appeared like an inconsistency to Local Io. From the white leaders' perspective, making a board position available only to a Black member of the union would be discrimination in that it was the opposite of an open election. They rejected proposals suggesting the guaranteed position would not be for a Black musician but for a former member of Local 208 because Local 208 was, as they pointed out, synonymous with being "Negro." They also rejected any provision that would make board-member positions responsible to geographic districts, saying that this would be the same as making one position available only to African Americans. In these rejections, the representative from the national union board and the leaders of Local io revealed that they were not as ignorant of the existence of discrimina- 
tion as they feigned..$^{70}$ In fact, they seemed to have a developed working knowledge of the segregation of African Americans in the city, as well as that imposed by the union.

At this point, the leaders of Local 208 raised the question of why they were being compelled to join Local io and why Local to was not being compelled into Local 208. For this there was no direct answer, but the minutes from the meetings repeatedly refer to the merged union as the "surviving local," which was always assumed to be Local Io. If the leaders of Local 208 refused the merger, then the federation would simply dissolve its charter, leaving the members without representation or benefits, which would force them to join Local Io. $^{71}$ It appeared to the leaders of Local 208 that this was not integration as they defined it because the AFM did not see Local 208 as equal to Local Io. The leaders of Local Io argued that they were treating the members of Local 208 as equals by granting no special privileges to them.

The leaders of Local 208 continued to demand voting rights and representation, but little would come of it. "When members of Local 208 get into difficulties," the Black leaders asked, "who is going to be able to stand up like the current leadership?" "The Convention of the A.F. of M. will be lily-white, and what representation will the Negro have? There won't be any Negro at the convention unless there is some white man someone will call a nigger-lover." The leaders of Local to were unable to understand the constant demands for representation and were only able to reply by asking, "Do you object to nigger lovers?"72

The talks went on in this manner for over a year. Local 208 and Local Io were never able to understand one another, in part because of the distrust born of the racial system in Chicago. Though the leaders of Local io were for integration, they defined it as bringing Local 208 into Local Iо, making it seem as though Local 208 were a subsidiary of Local Io, because Local Io was the first local in Chicago. The leadership of Local 208 was vocal about not being swallowed up by the white local. Integration, in the perspective of the Black leaders, was not be about strengthening Local Io, but about protecting the membership and the accomplishments of Local 208 from Local Io. The definition of what integration was became the core of the negotiations for the merger. Ultimately, the talks broke down completely on March 23, I964. In response, the national board took drastic measures. The issue that ended the talks was Local Io's ultimatum that Local 208 accept that there would be two positions on the executive board reserved for former members of Local 208 and the leaders of Local Io would appoint these board members. This was a demeaning proposition 
from the perspective of the Black leadership because it was an attempt to placate demands for representative democracy with tokenism. Local 208 denounced the idea as creating "Uncle Toms" and demanded an election be held. ${ }^{73}$ Local ro had already taken on Red Saunders and Leon Washington, leaders of the dissidents, as informal advisors. It was the Black leaders' fear that these men would fill the two appointed positions on the board. ${ }^{74}$

The union's national body-in a move that suggested that there were some white leaders who supported Black rights in the union, even if it was just for expedience-recommended that the merger grant the members of Local 208 full membership in Local Io. In this plan, the merged local would have a combined executive board, composed of members of both the white and the Black locals, until the finalization of the merger. Also, the plan included a provision that the terms of office of the current Black leaders would end when the merger talks were completed, but that members of Local 208 would be able to vote for their own representatives to serve on the governing boards of the merged locals, which included three board members. ${ }^{75}$ When the American Federation of Musicians' Executive Board issued its merger plan, in April I964, "Local 208 accepted the plan . . . but Local ro rejected it and in due course appealed the decision of the Executive Board. . . ."76

From the point of view of the leaders of Local 208, Local ro rejected the merger plan of April I964 because the plan contained a provision that only Local 208 members would be eligible to vote for Local 208 officers in the first election after the merger. ${ }^{77}$ This drove leaders from Local ro to stop attending meetings. The executive board responded by placing the locals into trusteeship. The leaders of Local 208 stated that they were not in favor of the resulting merger plan. They objected partly because the trusteeship ended the potential for further negotiations, which they felt took away the voice of the Black musician and meant that the white leaders never had to return to the table. Also, the property of Local 208 was to be sold after the merger so that Local ro could absorb the wealth of the Black local and not the physical property owned by the Black local. ${ }^{78}$

For their part, the leaders of Local ro argued that the merger plan presented by the union's national body "was prejudiced against the white majority" and would result in a continuation of segregation. ${ }^{79}$ After failing to win the negotiations, the white leaders became so frustrated that they blamed the merger problems on the leaders of Local 208, calling them "Black nationalists." 80 In doing so, the white leaders were inadvertently suggesting that Saunders and his fellows were now the establishment and the leaders of Local 208 had become the dissidents. Though they never 
acknowledged why the Black union leaders acted on such ideas, the white union leaders were not entirely incorrect in their assessment of the Black union leaders' intellectual genealogy. Being musicians, and being teachers, the Black union leaders were interested in Black cultural significance. They were also keenly aware of the economic realities of segregation and the potential for Black culture to serve as a resource in the fight for liberation. They did not think of these issues in a diasporic, metaphysical, or postcolonial sense; rather, they, like protestors throughout the city, understood the problems and their resistance as grounded in their relationship to the white power structure ${ }^{81}$-in this case, the union, as well as the city's socioeconomic underpinnings. At their core, the Black unionists' arguments were a reflection of Chicago's history of Black leaders who questioned whether it would be better to create an autonomous community from whites rather than fight for inclusion. The ideas expressed by the leaders of Local 208 were an example of how the uplift strategies of the early twentieth century survived and shaped the politics of the mid-twentieth century. ${ }^{82}$

\section{END GAME}

The merger did go through in 1966, after the federation put the Chicago locals in trusteeship. One reason for the merger's eventual realization was that the legal landscape of the United States had changed drastically after the passage of the I964 Civil Rights Act. The 1966 merger agreement allowed for two positions on the executive board to be voted on solely by former members of Local 208 for six years. The union's national board felt that six years would be enough time for "the members of Local io to be made aware of the intelligence of Negroes who might seek an office in the merged local." ${ }^{\prime 83}$

Though there was a merger, the established network of connections that existed in the white local continued to dominate the Chicago union. The highest paying and steadiest jobs continued to go to the white musicians. There must have been some dissatisfaction with the merger on the part of the former Local 208 members, because Red Saunders formed a new group called the Kole Facts Association (KFA) and issued broadsides that listed the benefits of the merger. Most of the gains were financial, such as lower taxes on the yearly union card and lower dues. There were also gains made in terms of organization. "Do you realize," the KFA letter stated, "you have a membership book listing all members and what they play ... there is a monthly union meeting ... you can voice your 
opinion, or express your grievances on any subject you so desire. . .." In addition, the KFA wanted to call the members' attention to the fact that five "negro musicians were employed in venues never before recognized to them. ..." The jobs included one record flipper at radio station WCFL, a nine-month run in the pit at the Schubert Theatre, and employment for three musicians employed at CBS studios, where they were paid \$225 a week with a promise of ten hours of work a week. ${ }^{84}$

Of course, the KFA letter did not explain that the five Black musicians employed in the radio stations, the Schubert Theatre, and CBS studios were all from the leadership of the Chicago Musicians for Harmonious Integration. ${ }^{85}$ Though these five Black musicians had found jobs in formerly white-dominated areas, the merger had not created a significant change in hiring practices, which is evident in the fact that discrimination continued to exist in the symphonies, the operas, and the bands at radio and television stations. Merging the two locals should have reduced the practice of discrimination, but it did not do so right away. It turns out there were not enough white musicians, conductors, and bookers in Chicago like Milton Preves. In fact, the reason given for not hiring Black musicians was the persistent stereotype that they could not read music. ${ }^{86}$ As a rumor, this one was insidious because it allowed for the demeaning of Black musicians while providing cover for racial prejudice. In response, because they were the only ones left to represent the Black members of the union, the KFA filed suits with the National Labor Relations Board against the American Federation of Musicians in 1967. ${ }^{87}$ Their lawsuits failed to cause a change in hiring practices. There would not be a Black member of the Chicago Symphony Orchestra until 2002. ${ }^{88}$

From the perspective of Tom Crown, a white trumpeter working in Chicago at the time, the situation was as confusing as it was sad. He was good friends with players, such as flautist James Mack, whom he suspected would have been a prominent figure on the national scene had he been white. ${ }^{89}$ Crown also had the experience before the merger of once filling in for a friend in a South Side venue, Roberts Show Lounge, which at the time was the largest Black-owned venue in the country..$^{90}$ Despite the fact that he was white and a young performer, he found that the other performers and the audience welcomed him. He knew there were individual musicians who found ways to "jump the color line," but he was also well aware that "segregation was pretty complete. . . Black bands played largely on the South Side, and white bands on the North Side," which included the symphony. In the years after the merger, he was aware that change was slow to come and, in the case of the symphony, reluctant to come. ${ }^{91}$ 
The dispute with the theaters and the symphony demonstrate that, even though they could theoretically work anywhere in the city for the first time in decades, the Black musicians gained few new jobs following the merger. Adding to their troubles, jobs in the "black belt" continued to disappear. The Black local in Chicago, like the Black local in Los Angeles, had a lower pay scale than the white local. Following the merger, the white local's scale was the standard. The small clubs that had been the Black musicians' primary venues since the Great Depression found it was cheaper to use jukeboxes and hire a disc jockey than to employ a live musician..$^{92}$ In addition, the city changed zoning laws in such a way that club owners had to start paying a tax for each musician in the bands employed in the clubs. ${ }^{93}$ The merger of the union and the change in zoning laws helped accelerate the shift from live music to recorded music in Chicago, thereby further displacing Black musicians.

The Black musicians felt conflicted because they disliked segregation but also lamented the loss of venues. Philip Cohran, later the leader of the Artistic Heritage Ensemble of Chicago, migrated to Chicago from Mississippi in the mid-I950s. He remembered the South Side as a "kind of Mec$\mathrm{ca}^{\prime}$ where the musicians "could walk up and down the streets and hear brothers playing everywhere...." Martin "Sparx" Alexander also migrated to Chicago in the mid-I950s. Like Cohran, Alexander recalled the South Side as a "paradise." ${ }^{\prime 94}$ Buddy Guy, who arrived in the city at the same time, contended that the "hood was always going down." watched as boarded up buildings and housing projects replaced the Black arts "Mecca" on the South Side. They noted that everything appeared to become more desperate as the South Side music scene began to vanish. Indeed, by 1972, guitarist Buddy Guy feared there would be no blues clubs left on the South Side. He purchased the Checkerboard Club, at 423 East 43rd Street, to prevent the total disappearance of the club scene. Later, he discovered that Muddy Waters's old house, 4339 South Lake Park, was in danger of being torn down. Guy purchased it as an homage to his late mentor and in an attempt to preserve the music history of the community. ${ }^{96}$

The musicians' despair over the diminishing music scene was part of the larger anguish being felt by the Black community caught up in the growth of Chicago's modern ghetto in the I950s and I96os. The community's feelings were palpable in songs such as "Political Prayer Blues" from I958, which transformed Psalm 23 and the Lord's Prayer into a protest song against President Eisenhower: "He maketh me to lie down upon park benches ... Yes, and surely hard times follow me ... And I will dwell in a housing project for the rest of my life. ${ }^{97}$ The replacing of the South Side 


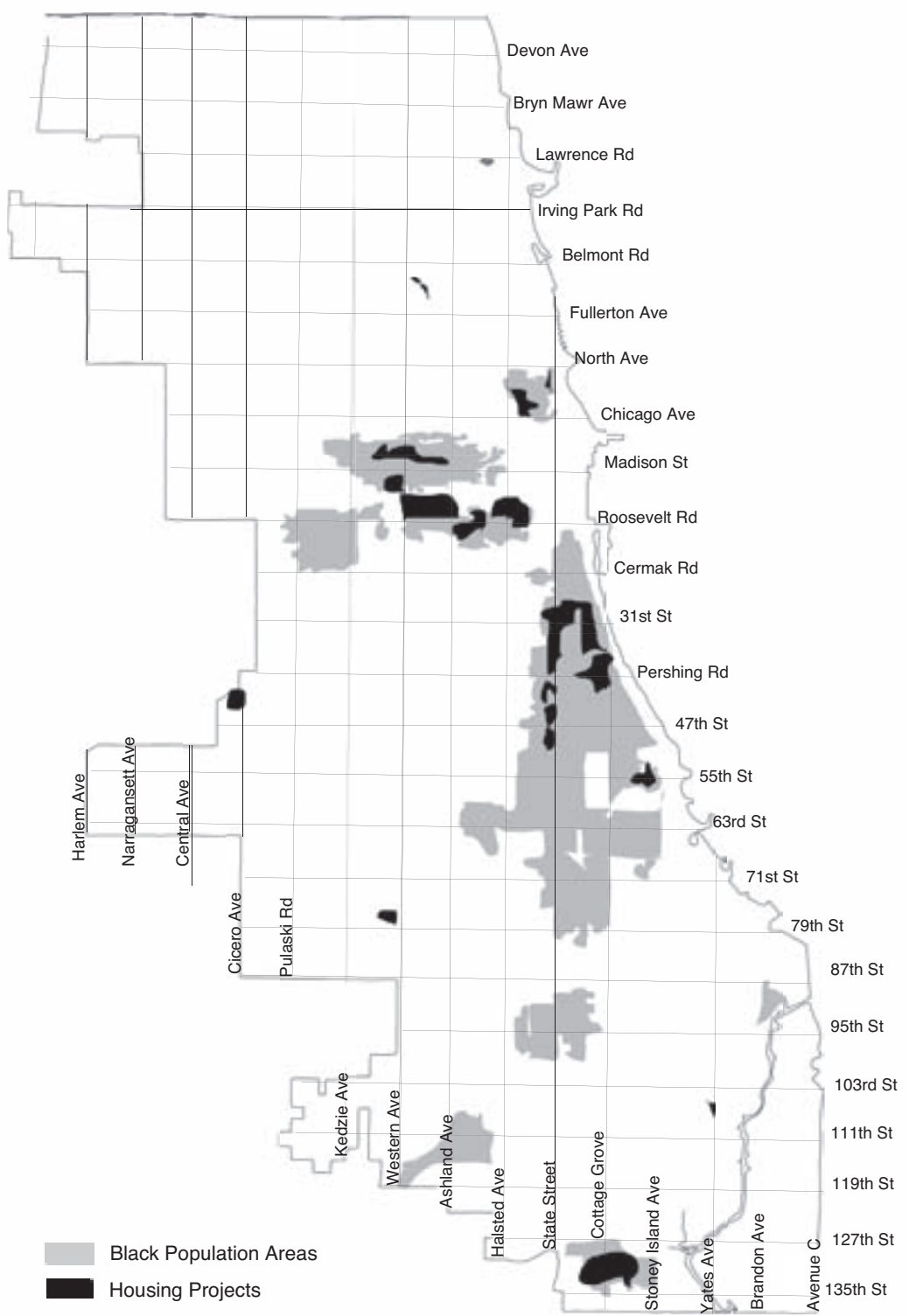

Map 8. This map shows the distribution of Chicago's African American population in reference to the city's public-housing projects in the mid-I950s. When compared with the music-venues map (chapter 2), it is apparent that the core of the historic "black belt" and Black music area-approximately 3 Ist Street to 55 th Street-was becoming the core of the projects. The building of the projects required the demolishing of Black neighborhoods. As the neighborhoods were destroyed, many of the music venues were destroyed as well. Based on Urban League and census maps housed in the Map Library, Regenstein Library, University of Chicago. Created by the author. 
streetscape with housing projects, and the subsequent growth in crime and poverty, became defining characteristics of the South Side in the I96os.

The existence of the "Mecca" for musicians on the South Side had stemmed in no small part from the Black union local's defense of and investment in the community. Regrettably, the post-merger years did not see the same level of black leadership and involvement in the union. There was great difficulty convincing the former members of Local 208 to run for office in the merged union. This resulted in the dissidents being perennial candidates as they worked to keep an African American voice in the union..$^{98}$ The former leaders of Local 208 did not run for office because of their age; they felt others saw them as holding up the merger to retain their power. ${ }^{99}$ By I993, the two Black delegates to the union's national convention, positions provided by the merger agreement and the union's subsequent civil-rights measures, were the only two African Americans serving in elected positions in Local IO-208.100

There were those among the Black musicians who were so angry at the way the union functioned, and the power of the white musicians, that they felt they could live without the union. In 1965, as Chicago's Black union local was imploding and the Black public sphere seemed to be failing, a group of African American jazz musicians gathered around a South Side kitchen table to discuss the future of Black music and the Black public sphere in the city. The group, led by cellist and pianist Muhal Richard Abrams, recognized that Chicago was no longer the creative center of jazz as it had once been because of the club closures on the South Side and the lack of Black-friendly venues in the rest of the city. They knew that if they were going to improve the situation for African American musicians, then they were going to have to create new opportunities for musicians. The group that emerged from these meetings was the Association for the Advancement of Creative Musicians, or AACM. The group could count among its members some of the most prominent jazz musicians of the second half of the twentieth century, including Lester Bowie, Philip Cohran, and Anthony Braxton. ${ }^{101}$

In imagining the new system of venues and a new kind of professional organization, the AACM members agreed on nine goals. Central to these goals was the recognition of the need for music-education programs that cultivated Black youth and a mentorship program that paired younger musicians with older, experienced musicians. The training that Abrams and the others envisioned would be free, would promote the traditions and achievements of Black music history, and would contribute to the programs at the Abraham Lincoln Center-a community performance 
hall in the "black belt." They hoped that in taking on the role of educators musicians would become community leaders and role models. It was no accident that they invested in education. Many of the members had been students of Walter Dyett's at DuSable High School. The relationship with Dyett taught them to have racial pride and showed them the power of education to fight the effects of Chicago's racism and poverty. ${ }^{102}$

AACM members agreed that their role in the community would be one of "uplift." The music they played at their shows would be original compositions. At the performances they would not allow drinking or smoking, which annoyed the music press. Also, they refused to perform in taverns and nightclubs. Instead, the AACM music movement was built in concert halls and community centers. They raised the money to rent the halls through community donation drives and they promoted the concerts themselves by distributing leaflets. Therefore, they managed to cut out the union, the club owners, and the promoters. ${ }^{103}$

Just as there were musicians who began to imagine a Black public sphere without the union, there were those who lamented the loss of the union local they had helped to build. An example of that loss was the sale of the Black local's business building following the merger. The headquarters of the merged local were the offices that Local ro had used for decades, which meant that the union leadership was located in what had been traditionally white territory. The location of the local's headquarters was significant because it symbolized the continued power of the white leaders and contributed to the lack of Black participation in elections and meetings. With the sale of the building, the Black musicians had lost a place to meet and look for jobs, their credit union, a place where they socialized, and a place where they could rehearse. In losing the building, they lost a large part of the Black cultural sphere, their community, as well as much of their status in the union. ${ }^{104}$

In the late I980s, the last vestiges of Local 208 disappeared from the Chicago music landscape. The local had owned an apartment building that provided low-cost housing for musicians and their families, but the merged local had decided to sell the building. This was shocking to the former members of Local 208. They believed that the merger agreement guaranteed that the union would always own the building. In addition, they felt that the union was wealthy enough that it could provide social services to its members. The closing of the building meant that there would no longer be a neighborhood of musicians as there once was. Singer, songwriter, playwright, and poet Oscar Brown Jr. summarized the event by saying it was as if the building were being "integrated out of ex- 


\section{Year of Joining the Union for White and African-American Musicians}

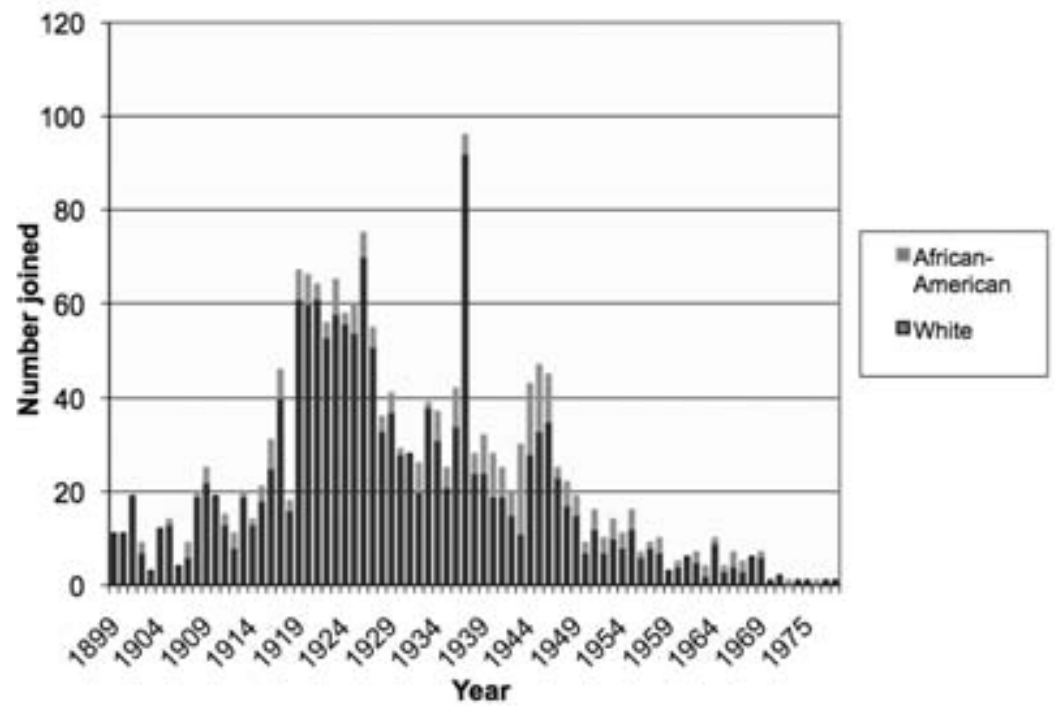

Place of Death (Different from Place of Birth and Chicago), Black Musicians

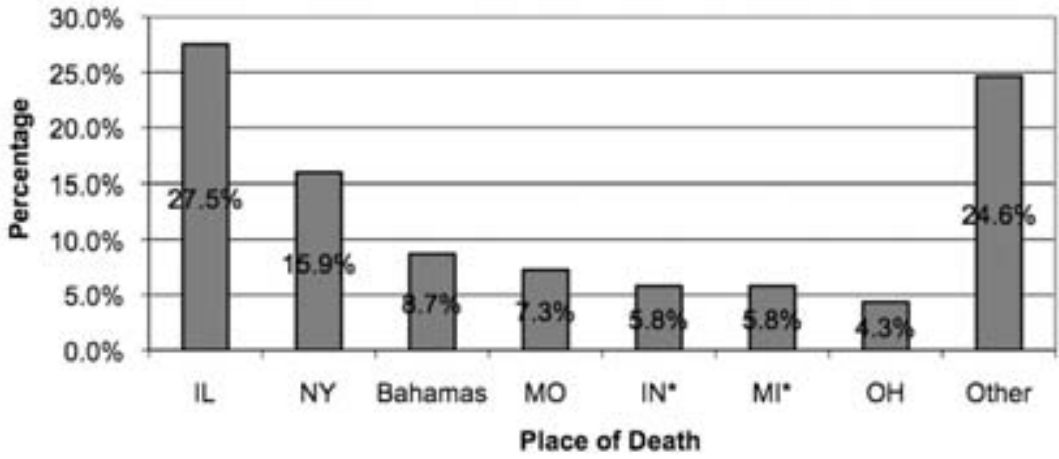

Figures 3 and 4 . The top chart shows the falloff of membership in the union. The two highest years for membership were I936-37, when Petrillo destroyed the last of the competing European ethnic unions and amalgamated their members into the AFM, and the World War II years, when large numbers of African American musicians were migrating to Chicago. The drop in membership rates can be attributed to the shift in the music industry to a bicoastal business model, the decline in significance of the union, and out migration as is demonstrated in the second chart. Based on a study of I,983 AFM death files. 
istence." ${ }^{105}$ This kind of integration had been, of course, the greatest fear of the Black Local's leaders.

In the early I990s, Black musicians reflecting on the merger expressed further disenchantment with integration. Lefty Bates, one of the first men to join Red Saunders's movement, argued, "The biggest mistake, when we merged, was the fact that they only asked for representation for 6 years. It should have been forever, or for a life time because there is not a single person to represent us down at Local Io-208 today." ${ }^{106}$ Charles Walton, another key member of Saunders's dissidents, summarized the merger by writing, "Blacks were not integrated into White locals, they were submerged." ${ }^{107}$ Walton would later help the AFM develop anti-discrimination policies and practices; Hillard Brown, a drummer who had worked as Local 208's business agent from I954 to I960, said, in the early I990s, that he wished that leaders of Local 208 had dissolved the local, sold the local's property, and distributed the profit from the sale among the members of the local. Brown also noted that when he had to go downtown to Local IO-208's building to pay his dues, "It was a cold situation. You had a place to pay bills and get your receipt, but no place to socialize like we had been accustomed to having on 39 th street [the former location of the Local 208 building], no exposure to other musicians." 108

The feelings of disappointment continued to be expressed forty years after the merger. There are now Black musicians working throughout the city, but white musicians still fill the higher-paying jobs. The perceived lack of employment in classical music, something Black musicians had been fighting since Dett's time, discourages young African American students from pursuing careers in symphony orchestras. ${ }^{109}$ For many, it is not a question of whether or not the racism is less overt or less institutionalized. What matters is that it still exists. For example, Morris Ellis, who found his start playing in Red Saunders's orchestra and was one of the 200 original dissidents, was disgusted with the merger and its results. He recalled the merger as being "forced" on the Black local and in the end accomplishing nothing. In making this argument, he cited two facts. First, Ellis was angry over the lack of African Americans elected to the union board since the time of the merger. "And to me that's a joke. A bad joke," Ellis proclaimed. The second reason for viewing the merger as a failure was the lack of African Americans in the Chicago Symphony Orchestra and on the symphony board. In reflecting on the history of discrimination and the lack of measurable improvements, Ellis angrily declared, "This is still the most segregated city in the world."110 


\section{Coda}

By the early to mid-I970s, Harry Gray, Walter Dyett, and Nora Holt, the founder of the NANM-had passed away. So too had Sam Cooke, Nat "King" Cole, and Memphis Minnie, who some believe was the first to use an electric guitar to play the blues. Howlin' Wolfe was enjoying renewed fame and European tours while fighting cancer. The band shell in Grant Park, located in downtown Chicago, was refurbished and renamed in honor of white AFM leader James Petrillo. New York-based GRT had purchased Chess Records. And, Muddy Waters had moved to Westmont, a middle-class suburb of Chicago. A new era in the history of Chicago musicians had begun.

What was the legacy of the migration generation of musicians? It is not hard to see their impact on the music industry. They were leaders in gospel, classical, jazz, and blues. They provided the foundation of rock and roll. Their music was more than popular culture; it offered insight into and gave a voice to the troubles and thoughts of the Great Migration. Partly as a result of their efforts, modern Black musicians have access to recording contracts and a diverse audience. Black musicians are no longer attacked by white racist groups in the South or refused public accommodations. Individual musicians and musicians' professional organizations, beginning in the early twentieth century, helped bring these changes about by bravely standing up to the long-held racial traditions in Chicago, the nation, and particularly throughout the South.

In the city, the greatest testament to the work of Black musicians is the endurance and importance of Black community organizations and Black music education. Many musicians in the early twentieth century, hoping for a classical music education, migrated to Chicago because of 
the presence of conservatories willing to accept Black students. Once in the city, through the efforts of NANM, they were able to extend music training to the Black community. Walter Dyett furthered music education by bringing jazz into part of the public-school curriculum. In so doing, he demonstrated that the Black music tradition was as much a part of academic training as any other form of music. ${ }^{1}$

Many of the founders of AACM attended DuSable High School, where they trained with Walter Dyett. ${ }^{2}$ Like NANM in the realm of classical music education, AACM created outreach and mentorship programs that brought children in off the streets for the purpose of music education. These programs, which began in the late I96os and still exist today, teach children the importance of maintaining Black music culture, discipline, and rigor. ${ }^{3}$ Though it may not be as visible to the outside world as the Stroll once was, these programs demonstrate that the Black public sphere is still alive, and constantly evolving, in Chicago.

By focusing on music education and professionalization, the community was able to help bring about the desegregation of the Chicago Symphony Orchestra. In 2002, Taje Larson, trumpeter, became the first Black musician in the CSO. Since then, the CSO has hired several Black musicians trained in a school run by the orchestra for minority students. In establishing a training program for minority students, the CSO finally acknowledged that a city's orchestra should serve and reflect its city.

The hiring of African American musicians ended more than roo years of segregation in the orchestra. These musicians are important symbols to the Black community because, as music professors at Columbia College in Chicago have noted, if Black music students do not see Black musicians in the orchestra, then they will think that careers in classical music are an impossibility. The struggle to desegregate the orchestra, the emphasis placed on building music-education programs, and the effort to provide opportunities for young musicians, suggests the longevity of Nathaniel Dett's argument. The Black musician is still fighting to emancipate Black music from the racist imagination of the white audience and white employers. The difference is that whereas Dett was only imagining the possibility of emancipation, now there are examples of those who succeeded at making real the dream. ${ }^{4}$ 


\section{Notes}

\section{INTRODUCTION}

I. Charles Willis Patterson, "A History of the National Association of Negro Musicians: The First Quarter Century I9I9-I943" (Ph.D. diss., Wayne State University, I993), 6, I I, 32-33; Suzanne Flandreau, "Classical Music in the Chicago Renaissance" (paper presented in a series of lectures on the Chicago Renaissance at the Vivian G. Harsh Collection, Woodson Regional Library, Chicago, Illinois, I998); see also John Webb, "Whispers of Love" (n.d.: unpublished manuscript, Center for Black Music Research, Columbia College, Chicago, Illinois).

2. Robert O. Self, American Babylon" Race and the Struggle for Postwar Oakland (Princeton, NJ: Princeton University Press, 2003), 2-3, IO-I I, I60.

3. Manning Marable, Race, Reform, and Rebellion: The Second Reconstruction in Black America, I945-I990 (Jackson: University Press of Mississippi, I99I), 226-27; Harvard Sitkoff, A New Deal For Blacks The Emergence of Civil Rights as a National Issue: The Depression Decade (New York: Oxford University Press, I978), 326-35; James R. Grossman, Land of Hope: Chicago, Black Southerners, and the Great Migration (Chicago: University of Chicago Press, I989), 265.

4. Thomas Sugrue, Sweet Land of Liberty: The Forgotten Story of Civil Rights in the North (New York: Random House, 2008), xxv.

5. St. Clair Drake and Horace Clayton, Black Metropolis: A Study of Negro Life in a Northern City, (Chicago: University of Chicago Press, I945), I 2.

6. Robert Bone, "Richard Wright and the Chicago Renaissance," Callaloo 28 (Summer I986): 446-68.

7. Kenneth Bancroft Clark, Dark Ghetto: Dilemmas of Social Power (New York: Harper \& Row, I965).

8. Helen Walker-Hill, From Spirituals to Symphonies: African American Women Composers and their Music (Westport, CT: Greenwood Press, 
2002); Wallace Best, Passionately Human, No Less Divine: Religion and Culture in Black Chicago I9I5-I952 (Princeton, NJ: Princeton University Press, 2005).

9. William Barlow, "Looking Up At Down": The Emergence of Blues Culture (Philadelphia: Temple University Press, I989).

Io. Allan H. Spear, Black Chicago: The Making of a Negro Ghetto (Chicago: University of Chicago Press, I967), 8; Sugrue, Sweet Land of Liberty, xxiv.

I I. Christopher Small, Music of the Common Tongue: Survival and Celebration in Afro-American Music (London: John Calder, I987), 69-70.

I 2. Scott DeVeaux, The Birth of Bebop: A Social Musical History (Berkeley and Los Angeles: University of California Press, I 997).

I3. Eric Porter, What is this Thing Called Jazz? African American Musicians as Artists, Critics, and Activists (Berkeley and Los Angeles: University of California Press, 2002), xiii-xiv.

I4. Lawrence Levine, The Unpredictable Past: Explorations in American Cultural History (New York: Oxford University Press, I993), 36.

I 5. The Black Public Sphere Collective, The Black Public Sphere: A Public Culture Book (Chicago: University of Chicago Press, I995), I-3.

I6. Evelyn Brooks Higginbotham, Righteous Discontent: The Women's Movement in the Black Baptist Church, I880-1920 (Cambridge, MA: Harvard University Press, I993), I 85.

I7. James Gregory, The Southern Diaspora: How the Great Migrations of Black and White Southerners Transformed America (Chapel Hill: University of North Carolina Press, 2005), I 20.

I8. Guthrie P. Ramsey, Race Music: Black Culture from Bebop to HipHop (Berkeley and Los Angeles: University of California Press, 2003), I03-5; George Lipsitz, Time Passages: Collective Memory and American Popular Culture (Minneapolis: University of Minnesota Press, I990), 66, I I7, I36-38.

I9. Bakari Kitwana, The Hip Hop Generation: Young Blacks and the Crisis in African Culture (New York: Basic Books, 2002).

20. Gregory, The Southern Diaspora, I20.

2I. Otis Dudley Duncan and Beverly Duncan, The Negro Population of Chicago: A Study of Residential Succession (Chicago: University of Chicago Press, I957), 3 I.

22. Gregory, The Southern Diaspora, Io2-3, table A4.

23. Christopher Robert Reed, The Rise of Chicago's Black Metropolis, I920-I929 (Urbana: University of Illinois Press, 20I I), I I 6-I7.

24. Robin D. G. Kelley, "'We Are Not What We Seem”: Rethinking the Black Working Class in the Jim Crow South," Journal of American History 80 (June I993): p. 79. 


\section{CHAPTER I}

I. Ida B. Wells-Barnett, Crusade for Justice: The Autobiography of Ida B. Wells-Barnett (Chicago: University of Chicago Press, I970), 290-95.

2. Suellen Hoy, "Illinois Technical School for Colored Girls: A Catholic Institution on Chicago's South Side, I9 I I-I953," Journal of Illinois History 4 (Summer 200I): I03-I22. I was guided to this source by The Joseph Cardinal Bernardin Archives and Records Center, Archdiocese of Chicago.

3. Historical Statistics of the United States, Millennial Edition, s.v. "Chicago"; Chicago Commission on Race Relations, The Negro in Chicago: The Study of Race Relations and a Race Riot (Chicago: University of Chicago Press, I923), I07.

4. Chicago Commission on Race Relations, The Negro In Chicago, 106.

5. "Future of the Pekin Theater," Chicago Defender, July I9, I9II, 4; "'Lid' a Joke as Pekin Shimmies Defiance of Law," Chicago Daily Tribune, February I6, I920, I7; "Black and Tan," Chicago Daily Tribune, August 25, I920, 8; John Lester, "Rout 'Black and Tans,'" Chicago Daily Tribune, September 26, I920, I; "Pekin Slayer Gives Lead to Booze Graft," Chicago Daily Tribune, August 25, I920, I; "300 Arrested in Wholesale Anti-Vice Raids," Chicago Daily Tribune, July 22, I918, I3.

6. Robin Bachin, Building the South Side: Urban Space and Civic Culture in Chicago I890-I9I9 (Chicago: University of Chicago Press, 2004), 259.

7. The Vice Commission of Chicago, The Social Evil in Chicago: A Study of Existing Conditions With Recommendations by the Vice Commission of Chicago: A Municipal Body Appointed by the Mayor and the City Council of the City of Chicago, and Submitted as its Report to the Mayor and City Council of Chicago (Chicago: Gunthorp-Warren Print. Co., I9II) 38; Bachin, Building the South Side, 259.

8. John C. Putman, Class and Gender Politics in Progressive-Era Seattle (Reno: University of Nevada Press, 2008), I I 9-22.

9. Howard Roberts Lamar, The Far Southwest: I846-I9I2 (New Haven, CT: Yale University Press, I966), 500-504.

Io. David A. Gerber, Black Ohio and the Color Line: I860-I9Is (Urbana: University of Illinois Press, I976), 425-3I.

I I. C. Vann Woodward, Origins of the New South I 877-I9I3 (Baton Rouge: Louisiana State University Press, I95I), 35 I, 354, 479, 480; Jervis Anderson, This Was Harlem: I900-I950 (New York: Farrar, Straus and Giroux, I982), 56.

I2. Gary Grestle, American Crucible: Race and Nation in the Twentieth Century (Princeton, NJ: Princeton University Press, 200I), 80.

I3. The Vice Commission of Chicago, The Social Evil in Chicago, I I9, I43-45, I48-49; Bachin, Building the South Side, 259. 
I4. Bachin, Building the South Side, 259; "The Thirty-First Street Tenderloin," Chicago Defender, November 5, I903, 6.

I 5. "Chicago Resorts Turn Women Out," New York Times, October 6, I9I2, 9; "Vice Trust Men to be Revealed," Chicago Daily Tribune, October 9, I9I2, 2; "The Vice Crusade in Chicago; The Negroes' Part," Chicago Defender, October I2, I9I2, I.

I6. Edward Kennedy Ellington, Music is My Mistress (New York: Doubleday, I968), I3 I. A policy operator was part of an organized syndicate that ran illicit lotteries.

I7. "State Street: Its Pains, Pleasures and Possibilities," Chicago Defender, May 2, I9I4, I.

I 8. "'Lid' a Joke," Chicago Daily Tribune, February I6, I920.

I9. The Reminiscences of Milton Hinton (I97I), I8-19, in the Oral History Collection of Columbia University.

20. Bachin, Building the South Side, 247, 25 5, 275-77.

2 I. Bachin, Building the South Side, 256.

22. The Reminiscences of Charles Elgar, 25, in the Oral History Collection of the Hogan Jazz Archive, Tulane University. The racial mixing in the nightclubs outside of the "black belt," as observed by Elgar, had nearly disappeared from the city by the end of the I930s. Student papers prepared for a sociology project at the University of Chicago reveal that the customers at the city's dance halls outside of the "black belt" were European American ethnics by the late I930s. All of the student papers concluded that the halls were dominated by white street gangs. The papers do not mention any African American musicians. All of the students' research was impressive. They were able to interview patrons, listen in on conversations of patrons in the washrooms, interview proprietors, and gain access to the halls' mailing lists to determine where the patrons lived in the city. Constance Weinberger, Saul D. Alinsky, "The Public Dance Hall," Autumn quarter I928, a term paper prepared for Professor Ernest Burgess, Ernest Watson Burgess Papers, Box I26, Folder Io, Regenstein Library Special Collections, University of Chicago. "An Evening at the New American," unidentified student, paper prepared for Professor Ernest Burgess. Ernest Watson Burgess Papers, Box I30, Folder 6, Regenstein Library Special Collections, University of Chicago. "The Taxi Dance Hall," student identified as DeFillippis seat 43, term paper prepared for Professor Ernest Burgess, Ernest Watson Burgess Papers, Box I30, Folder 6, Regenstein Library Special Collections, University of Chicago.

23. "Mr. George A. Wilson," Chicago Defender, June 4, I9 Io, I; "E. H. Morris Wins Color-Line Suit Against Colonial Theater," Chicago Defender, June II, I9IO, I.

24. Chicago Commission on Race Relations, The Negro in Chicago, 2.

25. Chicago Commission on Race Relations, The Negro in Chicago, I 52. 
26. Chicago Commission on Race Relations, The Negro in Chicago, 2.

27. Chicago Commission on Race Relations, The Negro in Chicago, I 53.

28. Chicago Commission on Race Relations, The Negro in Chicago, Io8.

29. Chicago Commission on Race Relations, The Negro in Chicago, I I8.

30. Chicago Commission on Race Relations, The Negro in Chicago, I 2 I.

3 I. Chicago Commission on Race Relations, The Negro in Chicago, I 23.

32. Langston Hughes, The Langston Hughes Reader (New York: George Braziller, I958), 337.

33. Chicago Commission on Race Relations, The Negro in Chicago, 2-3.

34. Chicago Commission on Race Relations, The Negro in Chicago, 2-5.

35. "Riot Sweeps Chicago: Gun Battles and Fighting in Streets Keep the City in an Uproar," Chicago Defender, August 2, I9I9, I.

36. "'Lid' a Joke," Chicago Daily Tribune, February I6, I920, I7; Chicago Commission on Race Relations, The Negro in Chicago, 345.

37. Louis Armstrong, Louis Armstrong, in His Own Words: Selected Writings, ed. Thomas Bender (Oxford: Oxford University Press, I999), 33-35, 6667.

38. Chicago Commission on Race Relations, The Negro in Chicago, 32324.

39. Chicago Commission on Race Relations, The Negro in Chicago, 32324; Louise de Koven Bowen, The Public Dance Halls of Chicago (Chicago: The Juvenile Protective Association of Chicago, I917).

40. "Second Ward Citizens Should Demand Removal of Nootbar," Chicago Defender, October 20, I917, I2; "South Side Dry Cabarets Raided," Chicago Defender, July 27, I9I 8 , I.

4I. Chicago Commission on Race Relations, The Negro in Chicago, 344.

42. Louise de Koven Bowen, "The Colored People of Chicago," in Speeches, Address, and Letters of Louise de Koven Bowen Reflecting Social Movements in Chicago, vol I (Ann Arbor, MI: Edwards Brothers, I937), 263. Bowen was also a benefactor to Jane Addams's Hull House-a settlement house on Chicago's West Side that assisted the poor and migrant classes. She worked in leadership roles for the United Charities of Chicago, the Women's Club, the Boy's Club, the Women's City Club in Chicago, and the National Women's Suffrage Association. Walter Cade Reckless, Vice in Chicago (Chicago: University of Chicago Press, I933), 90-92.

43. Bowen, "Straight Girl on the Crooked Path," in Bowen, Speeches, vol. I, 4I 2 .

44. Bowen, "Road to Destruction Made Easy in Chicago," 395.

45. Bowen, "The Colored People of Chicago," 265.

46. Reckless, Vice in Chicago, 90-92.

47. Reckless, Vice in Chicago, 92-93; Bachin, Building the South Side, $282,248,284$. The commercial amusement businesses also provided a mecha- 
nism for Black politicians to enter the political life of the city, which ward politics dominated. For example, Oscar De Priest, who was the first Black city council member, began his political career as a precinct captain whose job was to collect favors for constituents. These favors included not enforcing rules, such as last call in the cabarets, in exchange for votes.

48. Reckless, Vice in Chicago, 93-95.

49. Kenney, Chicago Jazz, I50-53. The Volstead Act provided for the enforcement of the Eighteenth Amendment, which had outlawed the production, transportation, and sale of alcohol but did not make the possession of alcohol illegal. For more on this topic, see Mezz Messrow, Really the Blues (New York: Anchor Books, I972); Eddie Condon, We Called It Music: A Generation of Jazz (Boston: Da Capo Press, I992); and Sidney Bechet, Treat It Gentle (London: Casell, I960). All three musicians chronicled what it was like to work in the syndicate owned resorts and clubs in Chicago during the I920s.

50. The Wonder Book of Achievement ([Chicago?]: Chicago Bee, I932?), 6I, 65. The Wonder Book of Achievement is located in the rare book collection of the Center for Black Music Research, Columbia College, Chicago . This was a publication sponsored by the African American owned newspaper the Chicago Bee. Its purpose was to promote the achievements of Chicago's Black community and to rally said community to prepare for the coming World's Fair.

5I. The Wonder Book of Achievement, 65

52. Wallace Best, Passionately Human, No Less Divine: Religion and Culture in Black Chicago I9I 5-I952 (Princeton, NJ: Princeton University Press, 2005), 37, 38-39.

53. James R. Grossman, Land of Hope: Chicago, Black Southerners, and the Great Migration (Chicago: University of Chicago Press, I989), I92.

54. "South Side Cabarets Raided," Chicago Defender, July 2I, I9I8, I; "Second Ward Citizens Should Demand Removal of Nootbar," Chicago Defender, October 20, I9I7, I2; "Gunmen Attempt to Shoot Up Dreamland," Chicago Defender, December 8, I923, I.

55. "New Entertainers and New Manager at Dreamland Café," Chicago Defender, January 20, I923, 4; "Dreamland Open," Chicago Defender, December 29, I923, 5; "Chicago Theatrical News," Chicago Defender, April I3, I929, 6 .

56. Bachin, Building the South Side, 254.

57. "Mr. George A. Wilson," Chicago Defender, June 4, I9 Io, I; "E. H. Morris Wins Color-Line Suit Against Colonial Theater," Chicago Defender, June I I, I9I0, I.

58. Davarian Baldwin, Chicago's New Negro: Modernity, the Great Migration, and Black Urban Life (Chapel Hill: University of North Carolina Press, 2007), 235-36. 
59. Best, Passionately Human, 36-37.

6o. Bachin, Building the South Side, 264.

6r. Derek W. Vaillant, "Sounds of Whiteness: Local Radio, Racial Formation, and Public Culture in Chicago, I92I-I935," American Quarterly 54 (March 2002): 25, 26, 27, 29.

62. Vaillant, "Sounds of Whiteness," 36-37.

63. Vaillant, "Sounds of Whiteness," 38-39; Best, Passionately Human, II6.

64. Anderson, This Was Harlem, 62.

65. Grossman, Land of Hope, I29; Gerstle, I 2 I.

66. Wells-Barnett, Crusade for Justice, 290-95. For further analysis of Wells-Barnett's role in shaping Chicago's African American community see Mildred Thompson's Ida B. Wells-Barnett: An Exploratory Study of an American Black Woman, I893-I930 (New York: Carlson Publishing, I990). Also see Joe W. Trotter's The Great Migration in Historical Perspective: New Dimensions of Race, Class and Gender (Bloomington: Indiana University Press, I99I).

67. Wells-Barnett, Crusade for Justice, 290-95.

68. "Loud Talking in the Pekin," Chicago Defender, April 23, I9Io, I; "The Home Club at the Pekin Theater," Chicago Defender, July 2, I910, 7; "Future of the Pekin Theater," Chicago Defender, July 29, I9 I I, 4.

69. Glenda Elizabeth Gilmore, Gender and Jim Crow: Women and the Politics of White Supremacy in North Carolina, I 896-I920 (Chapel Hill: University of North Carolina Press, I996), I74-75.

70. Anne Meis Knupfer, The Chicago Black Renaissance and Women's Activism (Urbana: University of Illinois Press, 2006), 32.

7 I. Richard Wright, I 2 Million Voices (New York: Thunders' Mouth Press, I94I, I988), I26-27.

72. St. Clair Drake and Horace R. Cayton, Black Metropolis: A Study of Negro Life in a Northern City (New York: Harcourt Brace, I945), 7 I 8.

73. Jasmine Farah Griffin, Who Set You Flowin': The African American Migration Narrative (New York: Oxford University Press, I995), I65.

74. R. Nathaniel Dett, "The Emancipation of Negro Music," 9-IO, NANM Collection, Columbia College, Chicago. Also available in R. Nathaniel Dett Reader. According to Anne Key Simpson in her biography of Dett, Follow Me: The Life of R. Nathaniel Dett (Metuchen, NJ: Scarecrow Press, I993), he spent the school year of I9I9-I920 on leave from Hampton studying at Harvard, where he won the Bowdoin Prize, a literary award, in May I920 for "The Emancipation of Negro Music." Though the Dett Reader gives the title of the piece as being "Negro Music," the copy of the piece in the NANM collection has separate sections, with "The Emancipation" as the first section, followed by "The Development of Negro Secular Music" and "Negro Music of the Present." 
75. Dett, "The Emancipation of Negro Music," Io, NANM Collection.

76. Dett, "Development of Negro Secular Music," I I-I3, NANM Collection.

77. Patterson, "A History of the National Association of Negro Musicians," 6, II, 32-33; Flandreau, "Classical Music in the Chicago Renaissance"; See also Webb, "Whispers of Love."

78. Dett, "Negro Music of the Present," 20-2 I.

79. Suggested listening includes Dvorak's Symphony No. 9 "From the New World," Mahler's and Britten's work with British folk music, Shostakovich's work with Jewish folk music, and Bizet's use of Cuban rhythms in Carmen.

80. Patterson, "A History of the National Association of Negro Musicians," 6, II, 32-33; Flandreau, "Classical Music in the Chicago Renaissance"; see also John Webb, "Whispers of Love."

8I. The American Federation of Musicians formed in I 896 under the supervision of Samuel Gompers and the American Federation of Labor (AFL).

82. For further discussion of this topic see Elijah Wald, Escaping the Delta: Robert Johnson and the Invention of Blues (New York: Amistad, 2004); James C. Cobb, The Most Southern Place on Earth: The Mississippi Delta and the Regional Identity (New York: Oxford University Press, I992).

83. Armstrong, Louis Armstrong, 33.

84. Armstrong, Louis Armstrong, 33-35.

85. Armstrong, Louis Armstrong, 33-35, 66-67. The Fiume, a nightclub located on State Street north of 35 th Street, opened in I9I9.

86. Condon, We Called it Music, Iо०, I05; Sidney Bechet, Treat it Gentle: an Autobiography (Boston: Da Capo Press, 2002).

87. The Reminiscences of Milton Hinton, I 5-I7.

88. Roger House, "Work House Blues: Black Musicians in Chicago and the Labor of Culture in the Jazz Age," Labor: Studies in Working-Class History of the Americas 9 (Winter 2012): 105.

89. Terry Teachout, Pops: A Life of Louis Armstrong (New York: Houghton Mifflin Harcourt, 2009), I I 2.

90. Muddy Waters, "Got a Right to Sing Blues-Muddy Waters," Chicago Defender, March 26, I955, 6.

9I. The Cry of Jazz, produced and directed by Edward O. Bland, Unheard Music Series, I959, DVD.

\section{CHAPTER 2}

I. Robert Gordon, Can't Be Satisfied: The Life and Times of Muddy Waters (Boston: Little, Brown, 2002), 64. 
2. Samuel Floyd, "An Oral History: The Great Lakes Experience," Black Perspective In Music I I (Spring I983): 4I, 46-50.

3. "B. B. King," interview, Sue Cassidy Clark Collection, Center for Black Music Research, Columbia College, Chicago, August 22, I968, Cd \#5 I. Sue Cassidy Clark is a music journalist. The collection consists of her interviews with musicians to support articles she wrote for Rolling Stone, Cream, and many other publications during the I960s and I970s. In regard to the antidiscrimination law, the migrants did not know, until they arrived in the city, that the city's government rarely enforced the state law outlawing discrimination in public areas. There were laws outlawing interracial marriage. Schools were segregated without passing laws. Principals, teachers, and administrators took it upon themselves to separate students. The segregation of housing also meant that neighborhood schools became totally white or totally Black.

4. "Muddy Waters: The Delta Sun Never Sets," Rolling Stone, October 5, I978, 55, 56 .

5. Gordon, Can't Be Satisfied, 69.

6. Pete Welding, "Afro-Mud: A Personalized History of the Blues," DownBeat, February 27, I975, 17, I8.

7. Jim O'Neal and Amy O'Neil, "Muddy Waters," Living Blues 64 (March/April I985): I7.

8. O'Neil, "Muddy Waters," 23.

9. James Gregory, The Southern Diaspora: How the Great Migrations of Black and White Southerners Transformed America (Chapel Hill: University of North Carolina Press, 2005), I 20. For further analysis of musician migration patterns, see the demographic study at the end of this book.

Io. Stewart E. Tolnay, "The Great Migration and Changes in the Black Family, I940-I990," Social Forces 75 (June I997): I 2 I3-38.

II. Thomas J. Sugrue, Sweet Land of Liberty: The Forgotten Struggle for Civil Rights in the North (New York: Random House, 2008), xv.

I2. Erik S. Gellman, "'Carthage Must Be Destroyed': Race, City Politics, and the Campaign to Integrate Chicago Transportation Work, I929-I943," Labor: Studies in Working-Class History of the Americas 2 (Spring 2005): 82, $84-85$.

I3. Gordon, Can't Be Satisfied, 64.

I4. Charles M. Payne, I've Got the Light of Freedom: The Organizing Tradition of the Mississippi Freedom Struggle (Berkeley and Los Angeles: University of California Press, I995), I2, 7; Stewart Tolnay and E. M. Beck, "Racial Violence and Black Migration in the American South, I9 Io to I930," American Sociological Review 57 (February I992): 103-I6.

I 5. Elijah Wald, Escaping the Delta: Robert Johnson and the Invention of the Blues (New York: Amistad, 2004), I 58-59; James Cobb, The Most South- 
ern Place on Earth: The Mississippi Delta and the Roots of Regional Identity (New York: Oxford University Press, I992), 282.

I6. John W. Work, L. W. Jones, and S. C. Adams, Lost Delta Found: Rediscovering the Fisk University-Library of Congress Coahoma County Study, I94I-I942, ed. Robert Gordon and Bruce Nemerov (Nashville: Vanderbilt University Press, 2005), 3 I 2-I 4. Lost Delta Found reproduces, in full, the Fisk University Study.

I7. Work, Lost Delta Found, 3 I I-I 4; "B. B. King," interview, Cd \#5 I.

I 8. Guido Van Rijn, The Truman and Eisenhower Blues: African-American Blues and Gospel Songs, I945-I960 (New York: Continuum, 2004), 50.

I9. Rijn, The Truman and Eisenhower Blues, I38; Sandra B. Tooze, Muddy Waters: The Mojo Man (Toronto: ECW Press, I997), 79.

20. Work, Lost Delta Found, 266-69.

2 I. Work, Lost Delta Found, 264-65

22. Margaret McKee and Fred Chisenhall, Beale, Black and Blue: Life and Music on Black America's Main Street (Baton Rouge: Louisiana State University Press, I993), 235.

23. Gordon, Can't Be Satisfied, 69.

24. Gordon, Can't Be Satisfied, 70, 72.

25. Gordon, Can't Be Satisfied, 7 I.

26. Paul Oliver, Conversations with the Blues (Cambridge: Cambridge University Press, I997), I49.

27. Oliver, Conversations, I46.

28. Mike Rowe, Chicago Blues: The City and the Music (London: DaCapo, I973), 49.

29. Pete Welding, "Muddy Waters-Last King of the South Side," DownBeat, October 8, I964, I9.

30. Gordon, Can't Be Satisfied, 7I. In I943, when Waters arrived in Chicago there were no clubs in the city willing to take a chance on his southern style of blues-which, lyrically and in instrumentation, was a sharp contrast to the blues recorded by the major music corporations for the prior twenty years. The slide guitar- and harmonica-driven music of Waters's generation of Chicago musicians was aggressively loud and lyrically was less concerned with despair than with anger and the assertion of individual worth. He played because "I wanted to work-not because anyone wanted me. . . If I had been forced to depend on my income as a musician, I would have starved to death." Welding, "Muddy Waters," 6.

3I. For more information regarding Memphis Minnie see Paul Goran and Beth Goran, Woman with Guitar: Memphis Minnie's Blues (Boston: Da Capo Press, I992). A "cutting contest" occurs when two or more musicians challenge each other on stage. They generally occur in rehearsals or in after-hours clubs. Dolly Jones was born in Chicago in I906. Trumpeter Roy Eldridge re- 
called that when he first met Jones he was standing outside a club in Detroit. He heard a trumpeter playing. "And when I come, they was on their break, you know. So I went up to the bar. . . . So the girl was sitting up there with her long dress on, holding a trumpet. . . . I was tuning my horn up. . . . So I said, 'Where's the trumpet player?' She said, 'I'm the trumpet player.'" Eldridge recalled cursing to himself. "Boy, this chick tore it on that trumpet, and my mouth flew open. ... Do you know, we battled until two o'clock in the afternoon. . . She could play." Reminiscences of Roy Eldridge (I982 -I983), 39-40, in the Oral History Collection of the Jazz Institute, Rutgers University.

32. Gayle Wald, Shout, Sister, Shout! The Untold Story of Rock ' $n$ ' Roll Trailblazer Sister Rosetta Tharp (Boston: Beacon Press, 2007). Tharp, with her mother-a Church of God in Christ evangelist-migrated from Arkansas to Chicago in the late I930s. Working in Chicago, Tharp redefined what gospel performers sounded and looked like. Most women in the churches played organ or piano: she played electric guitar like a blues musician. Before Tharp, congregational choirs performed the music in most churches. In contrast, Tharp was a solo performer, which was exceptional for any woman at the time. Though she stood alone on stage, Tharp was not alone in redefining gospel music at the mid-century. Roberta Martin ran one of the largest music publishing companies in the country at the time. The Roberta Martin Studio of Music opened in Chicago in I939 and built on Martin's successes as a composer and arranger. In addition, Martin was a leader in the South Side's clubs and church groups. Encyclopedia of American Gospel Music, s.v. "Martin, Roberta."

33. "Church of the Nazarene, 6344 Kimbark Ave, Woodlawn," and "Lincoln Memorial Congregational Church, 65th and Champlain Ave," I940, Box I 85, Folder 2, Ernest Burgess Collection, Special Collections, Regenstein Library, University of Chicago, Illinois.

34. Estelle Yancey was born in Cairo, Illinois, to southern migrant parents in I 896. Jane Bowers, "'I can stand mo trouble than any gal my size': Observations on the Meaning of the Blues of Estelle 'Mama' Yancey," American Music I I (Spring I993): 28-53.

35. Howard Saul Becker, "The Professional Dance Musician in Chicago" (master's thesis, University of Chicago, I949), 40. The lifestyle of the white musicians was a topic of study for University of Chicago sociologist Howard Becker. Becker lived and worked as a jazz pianist for fifteen months during I937 and I938 to gather the information needed to complete his master's thesis. The fact that he was European American limited Becker's research to the experiences of white musicians in the city. His subjects never mentioned segregation nor did they engage in the same types of jobbing activities as their African American counterparts.

36. Becker, "The Professional Dance Musician in Chicago," 40. 
37. Becker, "The Professional Dance Musician in Chicago," 4I.

38. $\mathrm{t}=2.84(\mathrm{p}=0.004)$.

39. $\mathrm{t}=2.17(\mathrm{p}=0.03)$.

40. Rheumatic heart condition or tuberculosis were listed as primary cause of death for 9 (o.6 percent) white and 5 (I.9 percent) Black musicians. Equal numbers of each race died from violent death -5 white and 5 Black musicians (0.3 percent and I.9 percent, respectively). It would be difficult to make a comparison between the statistics concerning musicians and the general population. The Illinois Department of Public Health began keeping death rates based on race beginning in I959. Prior to this, the data is only present for the population as a whole. The existing data, both before I959 and after, is dubious given the presence of the repetition of certain numbers for each year, which suggests the numbers are not accurate. In addition, the population as a whole was only recorded once every ten years making comparisons between different years impossible.

4I. Lloyd B. Potter, "Socioeconomic Determinants of White and Black Males' Life Expectancy Differentials, I980," Demography 28 (May I99I): 303-2I.

42. Allan H. Spear, Black Chicago: The Making of a Negro Ghetto, I89oI920 (Chicago: University of Chicago Press, I967), 54-60.

43. Chicago was the first city to have segregated locals in the American Federation of Musicians. It may have created a model for segregation that other locals emulated. For example, the white local in Los Angeles, Local 47, controlled all of the film, television, and music studio jobs. L.A.'s Black Local 767 controlled the blues and jazz clubs on Central Avenue. Jonathan Zvi Sard Pollack, "Race, Recordings, and Rock ' $\mathrm{n}$ ' Roll: The American Federation of Musicians and the Popular Music Challenge, I940-I970" (PhD diss., University of Wisconsin-Madison, I999), I80.

44. The Reminiscences of Milton Hinton (I97I), 3-5, 7, I 5-I7, in the Oral History Collection of Columbia University.

45. "From the Editor's Desk," Music Master, September I942, 3, Merger Box \#4, Folder "Local Io- 208 Merger General," The American Federation of Musicians Local Io- 208 Collection, Harold Washington Library, Illinois; Samuels, Union and the Black Musician, 52-57.

46. William Everett Samuels, Union and the Black Musician: The Narrative of William Everett Samuel and Chicago Local 208 (Lanham, MD: University Press of America, I984), 52-57.

47. "From the Editor's Desk," Music Master, September I942, 3, Merger Box \#4, Folder "Local Io- 208 Merger General," The American Federation of Musicians Local Io- 208 Collection, Harold Washington Library, Illinois.

48. Samuels, Union and the Black Musician, 52-57.

49. Clark Halker, "A History of Local 208 and the Struggle for Racial 
Equality in the American Federation of Musicians," Black Music Research Journal 8 (Fall I988): 2 I4.

50. See Charles A. Sengstock, That Toddlin' Town: Chicago's White Dance Bands and Orchestras, I900-I950 (Urbana: University of Illinois Press, 2004).

5I. As an example, in I96I, Mr. James Casara petitioned for membership in the AFM. Because he was Mexican American and lived on the South Side, he was initially told to join the Black local. Mr. Casara protested and presented himself to the white local leaders who ruled that, "he is admittedly a Caucasian ... . Properly should have made application to join Local \#ıo." "Document \#2," [August 29, I96I] from "A Story of A Raid Called Integration," File "208 Merger Directive and Appeal, I964," Merger Box I, American Federation of Musicians Local Io-208 Collection, Harold Washington Library, Chicago. The number of Filipino and Mexican members of the union was less than I percent of the total membership between I 940 and I979. In each case, they were accepted to the white local. See the demographic study in the appendix for more on this topic.

52. Halker, "A History of Local 208," 2 I 4.

53. See the interviews with Barney Bigard and Bobby Christian in Charles Walton's Bronzeville Conversations: The Tempo of the Times The Struggle for an Integrated Musician's Union ([Chicago?]: Charles Walton, I993): I8.

54. Samuels, Union and the Black Musician, 59.

55. Geoffrey Parsons, Jr., and Robert M. Yoder, "Petrillo: Mussolini of Music," American Mercury 5 I (November I940): I8 I-87; Tim Anderson, "Buried Under the Fecundity of His Own Creations: Reconsidering the Recording Bans of the American Federation of Musicians, I942-I944 and I948," American Music 22 (Summer 2004): 23 I-69. Also see Robert David Leiter, The Musicians and Petrillo (New York: Bookman Associates, Inc., I953).

56. Parsons, "Petrillo: Mussolini of Music," I 8 I-87.

57. Robin D. G. Kelley, "'We Are Not What We Seem': Rethinking the Black Working Class in the Jim Crow South," Journal of American History 80 (June I993): 79.

58. From the interview with Morris Ellis from Timuel Black, Bridges of Memory: Chicago's First Wave of Black Migration (Evanston, IL: Northwestern University Press, 2003), 179.

59. From the interview with John Levy from Black, Bridges of Memory, 200.

6o. Black, Bridges of Memory, I77-80.

6r. "Dyett, Walter-Death File," American Federation of Musicians Local Io-208 Collection, Harold Washington Library, Illinois.

62. "Minutes from the merger meeting January 29, I964," Merger Box 2, Folder "Merger Transcripts," American Federation of Musicians Local Io-208 Collection, Harold Washington Library, Illinois.. 
63. "N.Y. Musicians Union Blasts At Jim Crow Locals," Chicago Defender, January 22, I944, 2.

64. The Reminiscences of Scoville Browne, 4-5.

65. The Reminiscences of Milton Hinton, (I978), in the Oral History Collection of Columbia University, 4-7; The Reminiscences of Scoville Browne, 4-6. Browne recalled hearing this rumor from Hinton.

66. The Reminiscences of Milton Hinton, 3.

67. The Reminiscences of Milton Hinton, 3.

68. The Reminiscences of Milton Hinton, 4-5.

69. The Reminiscences of Milton Hinton, 6-7.

70. The idea of the appropriation of space comes from Henri Lefebvre, The Production of Space (Oxford: Blackwell, I99I).

7I. Spear, Black Chicago, II I.

72. Spear, Black Chicago, 203.

73. Encyclopedia of African-American Culture and History, s.v. "African Methodist Episcopal Church."

74. Spear, Black Chicago, Ioo.

75. Spear, Black Chicago, i io.

76. For more on Wells-Barnett see "Lynch Laws in America," The Arena, January I900, I5-24. Also, her examination of the concept and consequences of the idea of civilization is given thorough consideration in Jennifer Wyse, Thomas Ratliff, and Precoda, Karl, "Reframing the Discourse of Civilization Through Ida B Well's The Red Record: Integrating Intersectionality, Metalanguage of Race, and Separate Spheres of Citizenship," (paper presented at the annual meeting of the $35^{\text {th }}$ Annual National Council for Black Studies, The Westin, Cincinnati, OH, 20II); Suzanne Flandreau, "Classical Music in the Chicago Renaissance" (paper presented in a series of lectures on the Chicago Renaissance at the Vivian G. Harsh Collection, Woodson Regional Library, Chicago, Illinois, I998); Hortense Thornton, "The Barbershop and Beauty Parlor in Afro-American Literature," Pacific Coast Philology, October 1979, 76-83; Davarian Baldwin, Chicago's New Negroes: Modernity, the Great Migration, and Black Urban Life (Chapel Hill: University of North Carolina Press, 2007), 89-90.

77. Raoul Abdul, Blacks in Classical Music: A Personal History (New York: Dodd, Mead \& Company, I977), I4-I5. For more on Florence Price see the following works: Helen Walker-Hill, From Spirituals to Symphonies: African-American Women Composers and Their Music (Urbana: University of Illinois Press, 2007); Florence Price, Music of Florence Beatrice Price: Short Organ Works, (Fayetteville, AR: ClarNan Editions, I995).

78. Doris Evans McGinty, ed., A Documentary History of the National Association of Negro Musicians (Chicago: Center for Black Music Research, Columbia College, Illinois, 2004), I 85-87. 
79. Information about classical venues was taken from the Theodore Stone Collection, The Center for Black Music Research, Columbia College, Chicago.. Theodore Stone was a classically trained singer and the president of the Chicago chapter of the NANM. He saved the majority of the programs from performances he attended from the late I930s through the I960s. I used this information to compile a list of venues and then plotted the venues with regard to jazz and blues clubs.

8o. The Reminiscences of Roy Eldridge, 49.

8I. Mike Rowe, Chicago Blues, 4.

82. Nadine Cohodas, Queen: The Life and Music of Dinah Washington (New York: Pantheon Book, 2004), 25; Dempsey J. Travis, An Autobiography of Black Jazz (Chicago: Urban Research Institute, I983), 2 I 2. The abuse suffered by musicians in the Stagebar and the Downbeat Room forced the Black union local to require Black musicians to boycott the clubs. The white local, in an atypical move to support the Black musicians, also, for a time, boycotted the clubs. The mutual agreement regarding the clubs speaks to how egregious the working conditions were. "Meeting Minutes," March I6, I944, Chicago Local 208, American Federation of Musicians Io-208 Collection, Harold Washington Library, Chicago.. I am grateful to Nadine Cohodas for this source.

83. Black, Bridges of Memory, I 25.

84. Timuel D. Black, Bridges of Memory Volume 2: Chicago's Second Generation of Black Migration (Evanston, IL: Northwestern University Press, 2008), I 24.

85. The Chicago Defender, various issues. To ascertain this information, I used musicians' oral histories, existing maps of venues, and the Chicago Defender to create a list of venues. Then, I searched the Chicago Defender for articles, reviews, photos, and advertisements for the venues to determine if the venues were trying to reach a Black audience and/or were employing African American artists.

86. Dempsey J. Travis, An Autobiography of Black Jazz (Chicago: Urban Research Institute, I983), I86.

87. Eric Porter, What is this Thing Called Jazz? African American Musicians as Artists, Critics, and Activists (Berkeley and Los Angeles: University of California Press, 2002), xiii-xiv.

88. Paul Oliver, Blues Fell This Morning: The Meaning of the Blues (Cambridge: Cambridge University Press, I960), I69.

89. Oliver, Blues Fell This Morning, 46.

90. Michael Taft, Talkin' to Myself: Blues Lyrics, I92I-I942 (New York: Routledge, 2005), 443..

91. Oliver, Conversations, p. I59.

92. Cobb, Most Southern Place on Earth, 283-84. 
93. Oliver, Blues Fell This Morning, I63.

94. As cited in Paul Oliver, Songsters and Saints: Vocal Traditions on Race Records (New York: Cambridge University Press, I984), 93-94; as cited in Wallace Best, Passionately Human, No Less Divine: Religion and Culture in Black Chicago I9I5-I952 (Princeton, NJ: Princeton University Press, 2005), I I I.

95. As cited in Best, Passionately Human, I 2 .

96. Sam Dennison, Scandalize My Name: Black Imagery in American Popular Music (New York: Garland, I982), 436-37.

97. Oliver, Blues Fell This Morning, 46.

98. Christopher Small, Music of the Common Tongue: Survival and Celebration in Afro-American Music (London: John Calder, I987), 69-70.

99. As cited in Oliver, Blues Fell This Morning, I 5.

Ioo. As cited in Oliver, Blues Fell This Morning, 46.

Iо . Guido Van Rijn, Roosevelt's Blues: African-American Blues and Gospel Songs on FDR (Jackson: University Press of Mississippi, I997), 2 I I.

I02. Rijn, The Truman and Eisenhower Blues, 50.

I03. Gordon, Can't Be Satisfied, 67. See James Gregory, The Southern Diaspora How the Great Migrations of Black and White Southerners Transformed America (Chapel Hill: University of North Carolina Press, 2005); and James R. Grossman, Land of Hope: Chicago, Black Southerners, and The Great Migration (Chicago: University of Chicago Press, I989).

I04. "Ed Bland," WaxPoetics, April/May 2007, 83-84.

I05. Edward O. Bland to Amy Absher, April 2I, 2008. This correspondence is housed in the archive at The Center for Black Music Research, Columbia College, Chicago.

I06. Bland to Absher, April 2I, 2008; "Djane Richardson oral history," Audio Recording, Helen Walker Hill Collection, Center For Black Music Research, Columbia College, Chicago (Ms. Richardson is Margaret Bond's daughter); The Reminiscences of Milton Hinton, 3-5, 7, I 5-I 7.

I07. The Reminiscences of Milton Hinton, 3I, in the Oral History Collection of Columbia University.

I08. Charles Willis Patterson, "A History of the National Association of Negro Musicians: The First Quarter Century I9I9-I943" (PhD diss., Wayne State University, I 9931, 32-33; "Civic Opera House Filled Sunday," Chicago Defender, April 4, 1936, 6; Milton Cantor, Black Labor in America (New York: Negro Universities Press, I 969); Allan H. Spears, Black Chicago (Chicago: University of Chicago Press, I 967). See Figure 2 for white musician work patterns.

I09. Margaret Bonds, "A Reminiscence," Helen Walker-Hill Collection, Box 5, Series 4, Composer Files: Bonds Article File \#8:I, I, Center for Black 
Music Research, Columbia College Chicago. "A Reminiscence" was published in Lindsay Patterson's The Negro In Music And Art, (New York: International Library of Negro Music and Life and History, I967), I90-93. It is interesting to note that Bonds found the book in an Evanston, Illinois, library. Within Chicago, books concerning African Americans or books written by African Americans were only available in one library-which is an indication of the presence of cultural segregation in the city, as well as the level of importance placed on African American culture. The library collection of African American history and culture in Chicago was the result of the tireless efforts of librarian Vivian Harsh.

I Io. Bonds, "A Reminiscence."

I I I. The Cry of Jazz was a low-budget independent film based on a manuscript Bland had written in the late r940s titled "The Fruits of the Death of Jazz." The film contains the only footage of legendary musician Sun Ra and his Arkestra in their Chicago period. Because the Arkestra performed in the film without pay, Bland had to film the musicians in shadows and in different costumes to evade the union rules. The result was that the musicians, stripped of their identities, became an abstraction representing the idea of jazz as "the musical expression of the negro experience." The Cry of Jazz, produced and directed by Edward O. Bland, Unheard Music Series, I959, DVD.

I I2. The Cry of Jazz.

I I3. The Cry of Jazz.

I I4. For more on Bonds's view of her work see Helen Walker-Hill's From Spirituals to Symphonies: African-American Women Composers and Their Music (Westport, CT: Greenword Press, 2002).

I I 5. Bland to Absher, April 2 I, 2008.

\section{CHAPTER 3}

I. Robert Gordon, Can't Be Satisfied: The Life and Times of Muddy Waters (Boston: Little, Brown, 2002), I46. See Historical Statistics of the United States, "Table DA546-565 Farms in the South, by race and tenure of operator I880-I974." This information was based on the U.S. Census of Agriculture for I954, I969, and I974. In I940, there were 54I,29I sharecroppers in the United States. By I959, the number of sharecroppers fell to I 2 I,037. The year I959 was the last year sharecropping was recorded, suggesting that it ceased to be a relevant category to census takers and statisticians.

2. James Segrest and Alex Rosen, Moanin' at Midnight: The Life and Times of Howlin' Wolf (New York: Pantheon, 2004), I07-8.

3. Segrest and Rosen, Moanin' at Midnight, ro8.

4. The Reminiscences of Milton Hinton, I 5-I7, in the Oral History Col- 
lection of Columbia University; Derek W. Valliant, "Sounds of Whiteness: Local Radio, Racial Formation, and Public Culture in Chicago, I92 I-I935," American Quarterly 54 (March 2002): 25, 26, 27, 29.

5. Otis Dudley Duncan and Beverly Duncan, The Negro Population of Chicago: A Study of Residential Succession (Chicago: University of Chicago Press, I957), 3 I.

6. James N. Gregory, The Southern Diaspora: How the Great Migrations of Black and White Southerners Transformed America (Chapel Hill: University of North Carolina Press, 2005), IO2-3, table A4.

7. This information is from the map of Chicago blues clubs in the I950s in Mike Rowe, Chicago Blues: The City and the Music (London: DaCapo, I973), 2I6; information on the racial geography is from the maps in Duncan and Duncan, The Negro Population of Chicago, figures 6-8.

8. Amy O'Neal, "Muddy Waters," Living Blues, March/April I965, I8; "Maxwell Street at Mid-Century," Chicago History 26 (Summer I997): 44-53.

9. Robert Palmer, "Muddy Waters: Delta Son Never Sets," Rolling Stone, October 5, 1978, 56; Susan J. Smith, "Beyond Geography's Visible Worlds: A Cultural Politics of Music," Progress in Human Geography 2 I (I997): 524.

Io. Palmer, "Muddy Waters," 55- 56.

I I. Gordon, Can't Be Satisfied, 88-89.

I2. Nadine Cohodas, Spinning Blues into Gold: The Chess Brothers and the Legendary Chess Records (New York: St. Martin's Griffin, 2000), 22, I 8.

I3. Gordon, Can't Be Satisfied, 89-90.

I4. Jeffery Paul Melnick, A Right to Sing the Blues: African Americans, Jews, and American Song (Cambridge, MA: Harvard University Press, I999), I69; Rich Cohen, The Record Men: The Chess Brothers and the Birth of Rock and Roll (New York: W. W. Norton, 2004), 28-29. Many African American intellectuals saw Jewish involvement with Black music as exploitative. As an example, see Harold Cruse's The Crisis of the Negro Intellectual (New York: Morrow, I967). The Chicago Defender also saw the white businessmen in the South Side as parasites, saying, "there are eight thousand white people doing business in the black district. I don't mean that they live in the district. I mean that more than eight thousand white people of different nationalities are getting rich on race money. . . . Remember eight thousand stores in your community, whose owners would fight against your buying a home in the same block in which one of the might live. Yet your labor is responsible for their success." A. N. Fields, "Fit to Deal With But Not to Live With," Chicago Defender, July 6, I935, Io. Buddy Guy, who arrived in the city in the late I950s after Chess had become the permanent recording company on the South Side, described the Chess brothers as "holding all the cards." They dictated how the musicians should play, they signed them to contracts that 
prevented them from recording for other companies, and never explained the realities of the publishing rights. It was difficult to persuade Leonard Chess to record a new sound or to sign a new artist. Buddy Guy and David Ritz, When I Left Home: My Story (Boston: Da Capo, 2012).

I 5. Christopher Small, Music of the Common Tongue: Survival and Celebration in Afro-American Music (London: John Calder, I987), 385; Bill C. Malone and David Stricklin, Southern Music/American Music (Lexington, Kentucky: University Press of Kentucky, 20031, 75; James Philip Jeter, International Afro Mass Media: A Reference Guide (Westport, CT: Greenwood Press, I996), 248. Though in the I920s there were Black-owned recording companies recording Black artists_-such as Black Swan in Harlem-these companies lacked the capital to compete against the larger recording companies, who quickly came to dominate Black music. The larger corporations could afford to market Black music to a small audience because they had a large catalogue to sell. Black music was not the only music sold in this style. Music by Latinos and Latin American artists was sold only to Spanish-speaking areas in South America and in the United States. Black music broke free of this marketing scheme in the late I940s.

I6. Robert D. Leiter, The Musicians and Petrillo (New York: Bookman Associates, Inc., I953), I64-65.

I7. "Petrillo's Ban On Recordings Reported Near the Test Stage," Chicago Defender, August 28, I948, 8; "Record Companies, Hoping To Avoid Having Machinery Rust, Pleased At Rumor Petrillo Is Talking Peace," Chicago Defender, September 25, I948, 8.

I8. Gordon, Can't Be Satisfied, 93-94. Probably, the recording would have charted on radio if the stations across the country had been playing African American artists.

I9. Gordon, Can't Be Satisfied, 94-95; Rowe, Chicago Blues, 7 I.

20. B. B. King, interview with Sue Cassidy, August 22, I968 (CD 5 I), Sue Cassidy Clark Collection, Center for Black Music Research, Columbia College, Illinois.

2I. The Reminiscences of Milton Hinton, 25, I2-I3.

22. Rowe, Chicago Blues, I26, 106.

23. "Sun Records Label Launched in Memphis," Billboard, March I953, from Galen Gart, First Pressings: The History of Rhythm and Blues, vol. 3 (Milford, NH: Big Nickel Publications, 1986), 22. First Pressings is a set of books that compile all of the Billboard articles concerning rhythm and blues music in the I950s. For each of the citations, I have chosen to provide the original article title and date, when possible. Seagrest and Rosen, Moanin' at Midnight, 90.

24. Seagrest and Rosen, Moanin' at Midnight, 9I-92. 
25. Seagrest and Rosen, Moanin' at Midnight, 98.

26. "Explosive Growth of R\&B Labels Seen as Industry Phenomenon," Billboard, May I6, I953, from Gart, First Pressings, vol. 3, 39. David Stowe, in his book Swing Changes: Big-Band Jazz in New Deal (Cambridge, MA: Harvard University Press, I994), argues that this trend toward independent producers, booking agents, as well as independent radio, began in the I930s.

27. "Pop-Country-Blues Disc Categories Merge Closer; Old Distinctions Fade," Billboard, September 7, I953, from Gart, First Pressings, vol. 3, 73.

28. "R\&B Disc Sales to White Audience Hypoed by Coast Deejay's Promotion," Billboard, May 24, I952, from Gart, First Pressing, vol. 2, 43. There was an extensive relationship between Black musicians and the Latino audience prior to the I950s. Jelly Roll Morton proudly claimed Hispanic heritage. Morton and other black performers, such as Ma Rainey, lived in and toured extensively in Mexico. Furthermore, in New York and Los Angeles, Black musicians regularly lived in the same neighborhoods with and performed with Latin musicians. This complex relationship between migrating peoples and cultural sharing influenced the content of lyrics, composition styles, and instrumental styles of Black music. For more information see Peter Narvaez, "The Influence of Hispanic Music Cultures on African-American Blues Musicians," Black Music Research Journal 22 (Supplement: Best of BMRJ, 2002): 175-96; Phil Pastras, Dead Man Blues: Jelly Roll Morton Way Out West (Berkeley and Los Angeles: University of California Press, 200I); John Storm Roberts, Latin Jazz: The First of the Fusions, I880s to Today (New York: Schirmer Books, I999).

29. Eric Nuzum, Parental Advisory: Music Censorship in America (New York: Perennial, 2001), IO2.

30. Cohodas, Spinning Blues into Gold, 36, 45, 2 I 7.

3 I. See interviews with Al Benson, Big Bill Hill, and Corky Lott in Norman Spaulding, "History of Black Oriented Radio in Chicago I929-1963" (PhD diss., University of Illinois at Urbana-Champaign, I98I), II7-32; and interviews with Clarence Harmon and Irma Thomas in William Barlow, Voice Over: The Making of Black Radio (Philadelphia: Temple University Press, I999), I65-68.

32. Barlow, Voice Over: The Making of Black Radio, I 68.

33. "DJ AS Good Music Editor," Variety, August 8, I95 I, 4I-42; "Also Too Many Disc Gimmicks," Variety, August I 5, I95 I, 45.

34. "Younger Pubs Endorse DJ's," Variety, August 8, I95 I, 4I; Joseph Carlton, "Sees Editorial A Pitch For Some Passe Music Pubs," Variety, August 8, I95 I, 4I; "This Pub Salutes the Disc Jock for Everything But Inventing Penicillin," Variety, August 8, I95 I, 4I.

35. "Younger Pubs Endorse DJ's," 4I; Carlton, "Sees Editorial A Pitch For 
Some Passe Music Pubs," 4I; "This Pub Salutes the Disc Jock for Everything But Inventing Penicillin," 4I.

36. "Avers Music Biz Started Payola," Variety, August 8, I95 I, 4I, 48; Al Brackman, "Lauds Deejays for Breaking Grip of Big Publishers on Music Biz," Variety, August I5, I95 I, 45; Ed Penney, " Disc Jockeys, Pubs, Record Cos. Co-op for the Common Good," Variety, August 22, I95 I, 49.

37. "Jockey Calls For More R\&B, Sponsorship To Shore Up Lagging Times Sales on Airwaves," Billboard, December 20, I952, from Gart, First Pressings, vol. I, I 26.

38. "Jockey Calls For More R\&B Sponsorship To Shore Up Lagging Times Sales on Airwaves," I 26.

39. "Notes from the R\&B Beat," February I953, from Gart, First Pressings, vol. 3, I6.

40. "Moondog Ball Lures Mob to Newark," Billboard, May 8, I954, from Gart, First Pressings vol. 4, 47; "Freed's Show Slotted in Five Add'1 Markets," Billboard, August I4, I954, from Gart, First Pressings, vol. 4, 80; "R\&B Jock Syndication Growing Factor in Field," Billboard, September I I, I954, from Gart, First Pressings, vol. 4, 92.

4I. "Week of May 29-Buy O' The Week," Billboard, May 29, I954, from Gart, First Pressings, vol. 4, 56; "R\&B Jock Syndication Growing Factor in Field," Billboard, September I I, I954, 92, from Gart, First Pressings, vol. 4, 92.

42. "Pop Music Rides R\&B Tidal Wave; Diskeries Seeking Another 'ShBoom,'" Billboard, August 2 I, 1954, from Gart, First Pressings, vol. 4, 83. This was not the first time that Black music became the center of the national youth culture. Scholars of jazz have long noted the importance of jazz to the formation of rebellious white youth culture and the importance of white youth to the generation of jazz-record sales. The majority of these scholars would argue against seeing jazz's popularity among youth as evidence of what Theodoro Adorno termed the "regression of listening." Instead, jazz scholars note that that the music was for sale but the promise of a life that transcended class, ethnicity, and race was not for sale. For more on this topic, see Neil Leonard, Jazz and the White Americans: The Acceptance of a New Art Form (Chicago: University of Chicago Press, I962); Kathy J. Ogren, The Jazz Revolution: Twenties America and the Meaning of Jazz (New York: Oxford University Press, I 989); Lewis Erenberg, Swingin' the Dream: Big Band Jazz and the Rebirth of American Culture (Chicago: University of Chicago Press, I998); Kenneth Brindas, Swing: The Modern Sound (Jackson: University Press of Mississippi, 200I).

43. "Notes from the R\&B Beat," Billboard, August I954, from Gart, First Pressings, vol. 4, 83; "Teenagers Going for 'Music with a Beat' as Industry Reaps a Financial Harvest," Billboard, April I7, I954, from Gart, First Pressings, vol. 4, 33 . 
44. "Teen-agers going for 'Music with A Beat' As Industry Reaps a Financial Harvest," 33 .

45. The memory of the incident forced Waters to explain, "It's the black man and the white woman, the ones they jealous of. You don't look up. I don't look up. But a Black woman could work for a white man all day long, that's fine, nice." Later in his career, when reflecting on the success of the white musicians who sought to build on his musical style, he noted a certain gratification at the acceptance of his music by white people. With affection, he referred to this section of his audience as "my white people," suggesting a shift in the power relationship as a result of the popularity of his music. Margaret McKee and Fred Chisenhall, Beale Black and Blue: Life and Music of Black America's Main Street (Baton Rouge: Louisiana State University Press, I993), 239; Gordon, Can't Be Satisfied, 344-45, I90.

\section{CHAPTER 4}

I. "Who the Hoodlums Are," Newsweek, April 23, I956, 3I-32; "Cole Cites Race Haters in Attack," Chicago Defender, April I2 , I956, 8; "Why I Sang in Alabama-Cole," Chicago Defender, April I2, I956, I. A year later, one of Cole's attackers was arrested for participation in a Ku Klux Klan attack on an African American handyman whom the attackers castrated and then left for dead on a highway. "Victim Fingers Klansman at Ala. Mutilation Trail," Chicago Defender, October 30, I957, 3..

2. Nat "King" Cole was born in Montgomery, Alabama, in I9I7. When he was a child, his family migrated to Chicago, where he sang in his father's church. Like many of the musicians of his generation, he received musical training from Captain Walter Dyett at Wendell Philips High School. Though he was trained in Chicago, he found it necessary to leave the city to pursue his career. In I936, Cole left the city to work as the leader of the jazz group the King Trio. Cole remained the leader of the group until I95 I. The trio was influential in American jazz and was quickly copied by other musicians, such as Art Tatum, Oscar Petterson, and Ahmad Jamal, who used the trio format with great success in the I950s. Cole's most noteworthy recordings were with Lester Young in the I940s, and his I950s recordings with full orchestras, which marked his transition from jazz to popular music. The New Grove Dictionary of Jazz, s.v. "Cole, Nat 'King'."

3. "'King' Cole Takes Out \$500 Life Membership in NAACP," Chicago Defender, April 24, I956, 2; "Singer Nat 'King' Cole Boosts NAACP, Buys Tickets Worth \$1000," Chicago Defender, October 2, I957, I 8.

4. "Mel Torme Cole's TV Guest Star," Chicago Defender, July 8, I957, I9; "Pearle Bailey is Cole Video Guest Tomorrow," Chicago Defender, July I 5, I957, I9; "Bob Mitchum Guests Cole Video Next," Chicago Defender, July 
25, I957, I8; "Nat Cole Show to Star 'Ella,'" Chicago Defender, September 9, I957, I7; "Murrow Visits Nat 'At Home' on Nov I," Chicago Defender, October 29, I957; "Nat to End His TV Show After 6o Weeks on NBC," Chicago Defender, November 30, I957; Daniel Mark Epstein, Nat King Cole (New York: Farrar, Straus and Giroux, I999), 288-9I.

5. "White Council vs. Rock n' Roll," Newsweek, April 23, I956, 32. The Citizens' Council held jazz and rock and roll to be equally dangerous.

6. "Should Negro Stars Avoid Jim Crow Fight?" Jet, March I7, I955, 62.

7. Mitch Miller, "June, Moon, Swoon, and Ko Ko Mo," New York Times Magazine, April 24, I955, 38; "R\&B Helping Race Relations, Platters Content," DownBeat, May 30, I956, I4; "R\&B Cracking Racial Barriers in Southwest Where It's Bigger Than Ever," Variety, July 6, I955, 43; Rob Roy, "It Makes Sense! TV Ban On 'Offensive' Lyrics," Chicago Defender, June I6, I956,; "Deep South R\&R Hassle," Billboard, April 7, I956, 20; "Segregationists Would Ban All R\&R Hits," Billboard, April 7, I956, I30; "Are Negroes Setting the Trends?" White Sentinel, July I955, 6; "Entertainment Field Promotes Race-Mixing," White Sentinel, August I956, I, 8; "Color Craze," Negro Digest, January I95 I, 96.

8. Rich Cohen, Marchers and Rockers: Chess Records and the Business of Rock and Roll (New York: W. W. Norton, 2004), I 5.

9. Michael T. Bertrand, Race, Rock, and Elvis (Urbana: University of Illinois Press, 2000), I 59.

Io. Bertrand, Race, Rock, and Elvis, 244.

I I. Langston Hughes, "Loud Speakers and Dirty Records Would Be No Loss To Civilization," Chicago Defender, February I6, I952.

I2. Linda Martin and Kerry Segrave, Anti-Rock: The Opposition to Rock 'n' Roll (North Haven, CT: Shoe String Press, I988), 23.

I3. Christopher Small, Music of A Common Tongue: Survival and Celebration in Afro-American Music (London: John Calder, I987), 380; "What is the Disease in Popular Music?" Liguorian, July I957, I3-I4; "Rock and Roll Called Disease," Catholic Choirmaster, Summer I956, 42; "The Compartmentalized Thinking of Ed Sullivan," Ave Maria, February 2, I957, 6. The "domino theory" of music comes from Frances Aparicio, Listening to Salsa: Gender, Latin Popular Music, and Puerto Rican Cultures (Hanover, NH: University Press of New England, I998) and Martin Brody's "Music for the Masses": Milton Babbitt's Cold War Music Theory," Musical Quarterly 77 (Summer I993): I6I-92.

I4. "A Warning to the Music Business," Variety, February 23, I955, 2; "Smooth Spice the Worst," 53.

I5. "Coast Jockeys Open Gab War on R\&B Cycle," Variety, March 23, I95 5, 4I; "Smooth Spice the Worst," Variety, December I, I954, 53. 
I6. "A Warning to the Music Business," Variety, February 23, I955, 2; "Smooth' Spice the Worst," Variety, December I, I954, 53.

I7. "A Warning to the Music Business," Variety, February 23, I955, 2; "Smooth' Spice the Worst," Variety, December I, I954, 53.

I8. Armstrong and Gillespie were interesting choices as ambassadors. Armstrong was world famous and represented an earlier form of jazz rather than the cutting edge of Black music at the time, which in the mid-I950s was embodied by Thelonius Monk, Charlie Parker, and Max Roach. By enlisting Armstrong, the State Department had a world-famous musician who did not, at least on the surface, represent subversive Black music culture. On the other hand, Gillespie was in his prime in the mid-I950s, but he had also lost his recording contract and had to disband his orchestra. Joining the State Department tours was a way for him to see the world, interact with musicians from different music cultures, and to provide work for his orchestra. Dizzy Gillespie and Al Frazier, To Be or Not . . to Bop: Memoirs (New York: Doubleday I979), 4I3-I6. For more on the State Department's intentions in organizing the tours see Penny M. Von Eschen, Satchmo Blows Up the World: Jazz Ambassadors Play the Cold War (Cambridge, MA: Harvard University Press, 2004).

I9. "U.S. Steps Up Cultural Front War; \$2,250,000 'Seed' Coin Aids Show Biz," Variety, March 23, I955, I; "Negative Global Impression," Variety, March 9, I955, I.

20. "Trade Views Off-Color Disk Situation With Mixed Feeling," Billboard, October 2, 1954, I9, 86.

2 I. "Finger Points at You!" Billboard, October 2, I954, I9.

22. "Finger Points at You!" Billboard, October 2, I954, I9.

23. "Stop Making Dirty R \& B Records," Cash Box, September 28, I954, I. The only full run of the Cash Box is available at the Library of Congress. I am indebted to Frank Latino for obtaining a copy of this source for me.

24. "Chi Commission Fingers Mobster Control of Jukes," Variety, April I7, I955, I.

25. Andre Millard, America on Record: A History of Recorded Sound (New York: Cambridge University Press, I995), 207, 224-25, 226; Cash Box, various issues.

26. "Divided We Fall," Cash Box, April 2, I955, 2.

27. "Ye-He-He-Hes, Baby," Time, June I 8, I956, 74; "Rock 'n' Roll," Time, June 23, I956, 33; Jonathan Kamin, "Parallels in the Social Reactions to Jazz and Rock," Black Perspective in Music 3 (Autumn, I975): 282. These are the first two articles in which Time refers to rock and roll.

28. Gertrude Samuels, "Why They Rock 'n' Roll-And Should They?" New York Times Magazine, January 27, I958, II. The reporter attended an Alan Freed show. Featured in this particular show were The Teardrops, Little 
Richard, Chuck Berry, and Jerry Lee Lewis. Though the audience, as the article suggests, was mostly white, the performers were an integrated group.

29. "Coast Jockeys Open Gab War on R\&B Cycle," Variety, March 23, I955, 4I; "Smooth Spice the Worst," Variety, December I, I954, 53.

30. "Coast Jockeys Open Gab War on R\&B Cycle," Variety, March 23, I955, 4I; "Smooth Spice the Worst," Variety, December I, I954, 53.

3 I. "Music hath Harms: Teen-Age Dance Ban to Curb Rock 'N' Roll," Los Angeles Times, August 3I, I956, I8; "Bias Blasted in Rock 'N' Roll Fight," California Eagle, August 9, I956, I, 4; "Rock 'N' Roll Banned," New York Times, September 20, I956, 29; "Gas Ends Rock 'n' Roll Riot," New York Times, November 4, I956, 20; "Rock 'N' Rollers Riot," New York Times, October I9, I959, 22; "Rock 'n' Roll Pied Piper," New York Times, May 20, I960, 62; "Freed Charge Stands: Boston Judge Refuses to Kill Indictment in Riot," New York Times, November 4, I958, I8; "Freed Is Indicted Over Rock 'N' Roll," New York Times, May 9, I958, 49; "Freed Show Fights Ban in New Haven," New York Times, May 7, I958, 37; "Alan Freed Wins Point: Boston Won't Press Anarchy Case in Rock 'N' Roll Riot," New York Times, March 7, I959, I9; "Race Mixing Sets of Wild Disorder: Press Urges Strict Segregation Policy," Citizens' Council, February I956, 2; "Says Public Dances to be Segregated," Houston Informer and Texas Freedman, September I, I956, I.

32. "Race Mixing Sets Off Wild Disorder: Press Urges Strict Segregation Policy," Citizens' Council, February 2, I956; "Nine Arrested During Rock 'n' Roll Brawl," Pittsburgh Courier, February I I, I956; "Negroes, Whites Fight at Virginia Rock 'n' Roll Dance," Jet, May 30, I957, 6I.

33. Rob Roy, "It Makes Sense! TV Ban on 'Offensive' Lyrics," Chicago Defender, June I6, I956; "Mobile Stations Quote Variety on Leer-ics, Will Not Broadcast Em'," Variety, March 23, I955, I; "Juve Assn Gets Support in Drive to Kayo Leerics Platters," Variety, July 20, I955, I; "Deep South Jockey's Junk 50\% of R\&B Wax," Variety, April 20, I955, 53; "Radio Outlets, Disc Jocks Launch Self-policing Setup vs. Leeric Wax," Variety, March 30, I955, 49; "Houston Radio Stations Ask Crime Commission to List Indigo Disk," Variety, March 23, I95 5, 49; "Houston's Wash-Out-The Air Committee," Variety, August 24, I95 5, 5 I; "Indie Diskers back WDIA's R\&B Bans," Billboard, October 30, I954, I6.

34. Christopher Small, Music of the Common Tongue: Survival and Celebration in Afro-American Music (London: John Calder, I987), 378-79.

35. Martin and Segrave, Anti-Rock, 85-87; Russell Sanjek, Pennies From Heaven: The American Popular Music Business in the Twentieth Century (Boston: Da Capo Press, I996), 396-438.

36. "A Warning to the music business," Variety, February 23, I955, 2; "Smooth' Spice the Worst," Variety, December I, I954, 53.

37. Martin and Segrave, Anti-Rock, 85-87. 
38. Martin and Segrave, Anti-Rock, 85-87.

39. Martin and Segrave, Anti-Rock, 85-87; Russell Sanjek, Pennies From Heaven, 396-438.

40. Martin and Segrave, Anti-Rock, 85-87; Sanjek, Pennies From Heaven, 396-438.

4I. Martin and Segrave, Anti-Rock, 89. Also see "Congress Investigation of Rock 'n' Roll," Times (London), September I9, I956, 75.

42. Martin and Segrave, Anti-Rock, 89.

43. Nadine Cohodas, Spinning Blues Into Gold: Chess Brothers and the Legendary Chess Records (New York: St. Martin's, 2000), I77-78. The payola scandal came to a head in 1959 when the federal government began to investigate the music industry. The result was that payola was deemed illegal because the listening audience was unaware that fees had been paid.

44. Responsibilities of Broadcasting Licensees and Station Personnel. Hearings before a subcommittee of the Committee on Interstate and Foreign Commerce. House of Representatives. 86 Congress. 2nd Session. Washington: GPO I960. pt I, 899-905.

45. Cohodas, Spinning Blues, I79-82.

46. Also see Deceptive Practices in Radio and Television. Hearings before the Select Subcommittee on Legislative Oversight of the Committee on Interstate and Foreign Commerce, House of Representatives, 86 Congress, 2nd Session. Washington: GPO I960. pt 2, I235-I368. Dick Clark was strongly cautioned by the committee to take seriously his role in broadcasting. Even though it appeared that he had not broken any laws, Clark promised that he would divest himself of his holdings in American broadcast companies, recording companies, distribution companies, and marketing companies. The committee may have found it difficult to determine if Clark was guilty of any wrongdoings because of the vastness of his holdings, which the congressmen captured in a series of diagrams and charts included with the published version of the hearings.

47. George Lipsitz, Time Passages: Collective Memory and American Popular Culture (Minneapolis: University of Minnesota Press, I990), I25; Martin and Segrave, Anti-Rock, ıoo; Glenn C. Altschuler, All Shook Up: How Rock ' $n$ ' Roll Changed America (Oxford: Oxford University Press, 2003), I 50-52.

48. "Trade Execs Generally Support Stand Vs. Indigo R\&B Lyrics," Variety, March 2, I953; "BMI V.P Burton Poses R\&B Quiz," Variety, March 9, I955, 49; "Trade Views Off-Color Disk Situation With Mixed Feeling," Billboard, October 2, I954, I9; Sanjek, Pennies From Heaven, 406.

49. Billboard Magazine, various issues.

50. Lipsitz, Time Passages, I23.

5 I. "Letters to the Editor," Variety, March 23, I955, 4I.

52. "Does Radio Play the Wrong Music," Sponsor, June 27, I95 5, 32, 33. 
53. Andre Millard, America on Record: A History of Recorded Sound (New York: Cambridge University Press, I995), 207, 224-25, 226.

54. "Radio Master Directory," Sponsor, March 30, I957, IOI-9. Sponsor reported on changes in the radio and television broadcast industry for advertisers. They published an annual "Negro Issue," which examined the needs and tastes of the growing African American populations. Their charts of radio broadcasters records those stations with Ioo percent "Negro Programming" on down to stations with less than ten hours a week of Black-oriented programming. In each issue, Sponsor made the argument that the Black audience was more sophisticated and larger than advertisers believed.

55. "Negro Market Basics," Sponsor, September 26, I960, I7-30; "NegroAppeal Programming: An Old Medium with Growing Potential," Sponsor, September 26, I960, I I-I3, 52.

56. "Directory for Media Buyers of Major US Negro Appeal Negro Radio Stations," Sponsor, July 26, I965, 60-78; "Madison Ave Looks at Negro Radio," Sponsor, July 26, I965, 44-47.

57. "Negro Radio 200 Plus," Sponsor, July 28, I952, 32-33, 78-83; "The Forgotten I 5,000,000, Part I," Sponsor, July 28, I952, 29-30, 76-77; "The Negro Stations Revolved Around Disk Jockey," Sponsor, September 20, I958, 8-9, 37-40.

58. "Radio Stations War For Negro Market," Chicago Defender, January I2, I963, 6..

59. "The Stylistics, Jerry Butler," interview, Sue Cassidy Clark Collection, Center for Black Music Research, Columbia College, Chicago, July 2 I, I972, Cd \#II7.

6o. An example of the suppression of Black political music was J. B. Lenoir's "Eisenhower Blues," which he recorded for Chicago's Parrot label in October I954. Radio stations complained about the content of song. Producers forced Lenoir to change the title of the song to "Tax Paying Blues," and to change the chorus of "I Got them Eisenhower blues" to "I got them tax paying blues." See van Rijn, Truman Eisenhower Blues, I06-7, I76. I am grateful to Suzanne Flandreau, at the Center for Black Music Research, and Paul Garon, at Beasley Books, for their assistance in locating this source.

6I. Bertrand, Race, Rock, And Elvis, I 88, 209; Carl Perkins and David McGee, Go, Cat, Go: The Life and Times of Carl Perkins, The King of Rockabilly (New York: Hyperion, I996), 203; John Goldrosen and John Beecher, Remembering Buddy Holly: The Definitive Biography (New York: Penguin Books, I987), 97; "Entertainment Field Promotes Race-Mixing," White Sentinel, August I956, I; Dave McGee, "Interview with Carl Perkins," Rolling Stones, April I9, I990, 75. In the late I970s, Muddy Waters explained that the South had changed so much in regards to racism that he was surprised by the difference. "I was in Tennessee-Murfreesboro-last week," he said. "Man, seem like 
it not no Tennessee-seem like Chicago." Margaret McKee and Fred Chisenhall, Beale, Black, and Blue: Life and Music on Black America's Main Street (Baton Rouge: Louisiana State University Press, I98I), 240.

62. Peter Guralnick, Dream Boogie: The Triumph of Sam Cooke (New York: Little, Brown, 2005), 52.

63. Bertrand, Race, Rock, and Elvis, I76-77; "Nat May Return to Dixie!" Pittsburgh Courier, May 5, I956, 2; "Promoters Holding to Southern Bookings, despite Cole Incident," Billboard, April 21, I956, 26; "Ten Nights with Billy Eckstine," Our World, July I952, 24; George Pitts, "Sugar Ray 'Excellent' in Try at Acting," Pittsburgh Courier, May 25, I957, 2 I; "Lloyd Price Blast Conditions on Road," Pittsburgh Courier, July 28, I956; "Mr. Jordan Goes to Town," Our World, January I948, I4; Helen Doob Lazar, "Living Blues Interview with James Cotton," Living Blues, Summer I987, 22-23.

64. "Rock 'n' Rollers Run Amuck Over Nation For Week," Chicago Defender, February 23, I957, 8. I am using Alan Freed's concerts in Chicago as a point of contrast with other cities. Both Black and white teenagers attended Freed's shows and the musicians were also integrated. The shows in Chicago did not result in any outbreaks of violence, whether among the audience or directed at the musicians, as they did in other cities.

65. Bertrand, Race, Rock, and Elvis, I76-77; Wynonie Harris, "Women Won't Leave Me Alone," Tan, October I954, 29-30, 76-77.

66. "Bombing Threats Alert Ala. Cops," Chicago Defender, November 24, I958.

67. Bertrand, Race, Rock, and Elvis, I79; "Little Richard Fans Riot, Toss Bottles at Louisiana Cops," Jet, May 30, I957, 6I; "I'm Just a Crazy Mixed-up Kid-Little Richard," Tan, October I957, 22; "Little Richard's Rock 'n' Roll Brings Fire," Jet, September 20, I956, 59.

68. "Cops Nab Ella Fitzgerald in Backstage Dice Raid," Chicago Defender, October 15, I955; Also see Dizzy Gillespie, To Be Or Not to ... Bop.

69. "Jail Rock 'N' Roller Chuck Berry," Chicago Defender, September 5, I959; "Find Singer Guilty in Girl Case," Chicago Defender, March 25, I96I; "Negro Singer Jailed," New York Times, August 29, I959.

70. Martin and Segrave, Anti-Rock, 72;

71. Altschuler, All Shook Up, I66-i67.

72. Altschuler, All Shook Up, I66-67; David J. Langum, Crossing Over the Line (Chicago: University of Chicago Press, I994), I79-80, I86.

73. Altschuler, All Shook Up, 77, I67.

74. Altschuler, All Shook Up, I66-67. Also see A DeWitt, Chuck Berry: Rock 'n' Roll Music (Ann Arbor, MI: Pierian Press, I985), 8, 30, 97, I09; Chuck Berry, Chuck Berry: The Autobiography (New York: Harmony, 1987), I99209; Brian Ward, Just My Soul Responding: Rhythm and Blues, Black Consciousness, and Race Relations (Berkeley and Los Angeles: University of Cali- 
fornia Press, I998), I I I-I 2; Berry v. United States, 295 F .2d I92, I93-94 (8th Cir. I96I), cert, denied, 368 U.S. 934 (I96I).

75. Guralnick, Dream Boogie, 526-27.

76. Lyrics as cited in Guralnick, Dream Boogie, 607, 54I, 5 I 2-I3.

77. Reminiscences of Roy Eldridge (1983), pp. 29-32, in the Oral History Collection of the Jazz Institute, Rutgers University.

\section{CHAPTER 5}

I. Carole Goodwin, The Oak Park Strategy: Community Control of Racial Change (Chicago: University of Chicago Press, 1979), The statistics are based on census data from I960 and I970.

2. "Report 25 Musicians Quitting Oak Park Symphony On Race Issue," Chicago Defender, February 23, I963, 4.

3. "Symphony Chief Rips Conductor in Bias Dispute," Chicago's American, February II, I963. from the Merger Box \#4, Folder "Chicago Musician Union Scrapbook," I04, American Federation of Musicians Local Io-208 Collection, Harold Washington Library, Chicago, From this point on, the collection with be abbreviated as AFM.

4. "Fifth of Oak Park Symphony May Quit Over Racial Snub," Chicago Defender, February I6, I963, I..

5. "Erase Stigma, Pastor Urges In Orchestra Racial Dispute," Chicago Sun-Times, February I I, I963, 30. from the Merger Box \#4, Folder "Chicago Musicians' Union Scrapbook,"

6. Andrew Diamond, Mean Streets: Chicago Youths and the Everyday Struggle for Empowerment in the Multiracial City, I908-I969 (Berkeley and Los Angeles: University of California Press, 2009), 26I, 287-300.

7. Al Foster, "Other People's Business," Chicago Defender, February 23, I963, 6; "Victory for Reaction," Chicago Defender, February I3, I960, I 2..

8. "Barred Violinist Decides Today If She Wants to Return to Symphony," Chicago Defender, February I3, I963, 3; "Barred Violinist to Play With Oak Park Symphony 'Just Once,'"' Chicago Defender, February I4, I963, 2.

9. "Carol Wins Cheers, Dad Flies Here For Concert," Chicago Defender, February I 8, I963.

Io. For instance, Ray Charles played the first integrated show in Memphis in "Ray Charles Stages Big First in Dixie Concert," Chicago Defender, August 28, I96I.

I I. "Music Man Scores Integration 'Hit,'" Chicago Defender, March 30, I963.

I2. Encyclopedia of Afro-American Music, s.v. "Gray, Harold."

I3. "Dyett, Walter-Death File," AFM; Bibliographical Dictionary of AfroAmerican Music, s.v. "Dyett, Walter Henri." 
I4. Bibliographical Dictionary of Afro-American Music, s.v. "Elgar, Charles"; Grove Dictionary of Jazz, s.v. "Elgar, Charles."

I 5. The Reminiscences of Charles Elgar, in the Oral History Collection of the Hogan Jazz Archive, Tulane University; The Reminiscences of Red Saunders, 42, 45, 47, 48 .

I6. "Music Union Merger Demanded By Core," Chicago Sun-Times, August 2I, I963, Merger Box \#4, Folder "Local Io-Local 208 Merger General," AFM; "Photographs of Protest," Merger Box \#2, Folder "Annual Meeting Local Io-Local 208, Local Io/6/I963." The Chicago History Museum houses the papers of the local branches of these organizations. The collections contain the group's constitutions, which articulate their dedication to integration and nonviolence, as well as newspaper clippings regarding the musicians. The margin notes on the clippings suggest that they did support the musicians' integration campaign but could not offer much help because they were busy staging protests against the segregated public schools. These protests occurred at the same time as Local 208's annual meeting and the start of the merger talks.

I7. "Minutes of the Annual Meeting, Local 208 AFM Sunday October 6, I963."

I8. Komozi Woodard, A Nation Within a Nation: Amiri Baraka (LeRoi Jones) and Black Power Politics (Chapel Hill: University of North Carolina Press, I999), 25.

I9. Lizabeth Cohen, Making a New Deal: Industrial Workers in Chicago, I919-1939 (Cambridge: Cambridge University Press: I990), 6.

20. Cohen, A New Deal, Welfare capitalists were manufacturers who developed social-welfare programs explicitly to encourage employees to depend on their bosses rather than apply for public assistance, or look toward union organizers. Most common in the I920s, the practice began to burn out during the Great Depression.

2 I. Malcolm, "The Musicians Building."

22. The AFM Collection at the Harold Washington Library contains the death records for the musicians from Local 208 and Local Io. A death record consists of the family's request for beneficiary payments, the original union card, death certificate, and any other relevant documents such as a comparison of the union cards from Local io and Local 208 reveals that the members of Local io were asked and were able to provide their addresses and phone numbers-which also reveals that many of them did not live in Chicago proper-whereas, the membership cards from Local 208 had no such information. Additionally, the death certificates of the members of Local 208, who died between I940 and I979, reveal that African American musicians lived twelve years less, on average, than did their white counterparts. African American musicians were also six times more likely to die a violent death. See the demographic study in the appendix for further information. 
23. Woodard, A Nation Within a Nation, 27-28.

24. See Erik Gellman, "'Carthage Must Be Destroyed': Race, City Politics, and the Campaign to Integrate Chicago Transportation Work, I929-1943," Labor: Studies in Working-Class History of the Americas 2 (Spring 2005): 8 II I 4 .

25. Woodard, A Nation Within A Nation, 30.

26. "Petrillo Fights Ouster Move," Chicago Daily Tribune, October 7, I96I.

27. Diamond, Mean Streets, 259.

28. Woodard, A Nation Within a Nation, 3 I-35.

29. Cohen, A New Deal, 6-7.

30. Robin Kelley, "'We Are Not What We Seem': Rethinking the Black Working Class in the Jim Crow South," Journal of American History 80 (June I993): 79.

3 I. Georg Leidenberger, Chicago's Progressive Alliance: Labor and the Bid for Public Streetcars (DeKalb: Northern Illinois University Press, 2006), 7.

32. Kelley, "'We Are Not What We Seem'," 79.

33. Eric Arnesen, "Up From Exclusion: Black and White Workers, Race, and the State of Labor History," Reviews in American History 26 (March I998): I 50.

34. The Reminiscences of Red Saunders (I978), 4-7, in the Oral History Collection of the Jazz Institute, Rutgers University.

35. The Reminiscences of Red Saunders, 84-The trial board hearings of Black Local 208 were either not recorded or did not survive. Saunders's account of this event is repeated in the oral histories in Charles Walton, Bronzeville Conversations: The Tempo of the Times: the Struggle for an Integrated Musicians Union (self-published: Charles Walton, I993). Morris Ellis's interview in Timuel Black, Bridges of Memory (Evanston, IL: Northwestern University Press, 2003) does offer a slightly different view of Saunders's actions. Ellis argued that Saunders was kicked out of the Black local following the conflict and sought to destroy the Black local out of spite. Black Saunders's membership file-housed in the American Federation of Musicians Io208 Collection-offers no evidence to support or refute Ellis's statement.

36. See the interviews with Ted Saunders Jr., Frank Derrick, Sunny Turner, and James Mack in Walton, Bronzeville Conversations, 4-5.

37. See the interview with Sunny Turner in Walton, Bronzeville Conversations, 5 .

38. Howard Saul Becker, "The Professional Dance Musician in Chicago" (master's thesis, University of Chicago, I949), I03-I05. See the interviews with Clifford Clark, James Mack, Sonny Turner, and Laney McDonald in Walton, Bronzeville Conversations, 6-7.

39. Bob Hunter, "CMHI Musicians Blast Local 208 Officials," Chicago Defender, September 24, I963, I6.. 
40. William Everett Samuels and Donald Spivey, The Union and the Black Musician: The Narrative of William Everett Samuels and Chicago Local 208 (Lanham, MD: University Press of America, I984), 52-57.

4I. "N.Y. Musicians Union Blasts At Jim Crow Locals," Chicago Defender, January 22, I944, 2.

42. Clark Halker, "A History of Local 208 and the Struggle for Racial Equality in the American Federation of Musicians," Black Music Research Journal 8 (Fall I988): 2 I4. Also, see chapter 2: Reminiscences of Red Saunders.

43. "Musicians Union Victor Maps Drive To Increase Live Music in Chicago," Chicago Sun-Times, January I963; "7 Re-elected Petrillo Men Decide to Stay on the Job," Chicago Daily News, December 7, I963, Merger Box \#4, Folder "Chicago Musicians Union Scrapbook," AFM; "Chi Tooters' Racial Discord," Variety, July 3 I, I963, 95, Merger Box 3, "Miscellaneous Correspondence I964-I965," AFM.

44. "Music Man Scores Integration 'Hit,'" Chicago Defender, March 30, I963, Io. There is little else regarding this However, in the TWO's papers, there are newspaper clippings chronicling Saunders's actions, which indicates interest on the part of TWO. The group was very busy fighting the expansion of the University of Chicago, as well as working for betting housing and public schools. So, it is not a surprise that they did not involve themselves further in Saunders's revolt.

45. For biographical information regarding musicians see the following reference works: Encyclopedia of Afro-American Music; Encyclopedia of the Blues; The Blues Biographical Guide; and the Grove Dictionary of Jazz.

46. Frank Derrick Jr., "The Move For An Integrated Musicians Union," Charles E. Walton Collection Box 2, Vivien Harsh Collection, Woodson Library, Chicago, Illinois.

47. After the dissidents went public with their protests, the leaders of the local demonstrated their power over the musicians by firing the dissidents' wives who did office work for the local, refusing membership applications of the dissidents' relatives, and removing the dissidents from the membership rolls of the local (which destroyed the musicians' seniority and eliminated the possibility of a death-benefit payment). In addition, after the existence of the dissident movement became apparent, the dissidents began receiving death threats. Becker, The Professional Dance Musician in Chicago, I03-I05. See the interviews with Clifford Clark, James Mack, Sonny Turner, and Laney MacDonald in Walton's Bronzeville Conversations, 6-7; Bob Hunter, "CMHI Musicians Blast Local 208 Officials," Chicago Defender, September 24, I963, Ar6; Derrick, "The Move For An Integrated Musicians Union," Charles E. Walton Collection.

48. Becker, The Professional Dance Musician in Chicago, I03-105. See the interviews with Clifford Clark, James Mack, Sonny Turner, and Laney McDonald in Walton, Bronzeville Conversations, 6-For an example of a musi- 
cian in trouble with the union see Scott Dirks, "Elmore James and the Musicians Union," Living Blues, March/April 2002, 4I-45.

49. "20o Musicians Revolt, Join Mixed Union," Chicago Defender, March $21,1963$.

50. "200 Negroes Integrate Musicians Union Local," Chicago Daily News, March 21, I963; "Ioo Negro Musicians Join Local Io," Chicago Sun-Times, March 21, 1963; "Chicago Music Union Admits First Negroes," Chicago Tribune, March 21, 1963, all from Merger Box \#4, "Chicago Musicians Union Scrapbook," AFM.

5I. See the interviews with Clifford Clark, James Mack, Sonny Turner, and Laney MacDonald in Walton's Bronzeville Conversations, 6-7; Bob Hunter, "CMHI Musicians Blast Local 208 Officials," Chicago Defender, September 24, I963, AI6; Derrick, "The Move For An Integrated Musicians Union," Charles E. Walton Collection.

52. Bob Hunter, "CMHI Musicians Blast Local 208 Officials," Ar6. Also see Bronzeville Conversations.

53. Hunter, "CMHI Musicians Blast Local 208 Officials," Ar6. It should be noted that the "dissident" musicians were having to pay dues in both Local Io and Local 208. Eventually, Local 208 would attempt to strip them of their membership rights, such as death This would be a major contention in the merger meetings and it appears that the leaders of Local 208 wanted to punish the dissidents. This inclination only grew when it became known that the leaders of Local ro had hired the "dissident" leaders to act as advisers on issues of race.

54. "Negro Merger Unit Charges 'Packing' Plan," Chicago Sun-Times, September 25, I963, Merger Box \#4, Folder "Local Io-208 Merger General," AFM.

55. See images 7, 8, and 9. See also the interview with Clifford Clark in Walton, Bronzeville Conversations, 6.

56. "Minutes of the Annual Meeting, Local 208 AFM Sunday October 6, I963," 2, Box 2, Charles Walton Collection.

57. "Minutes of the Annual Meeting, Local 208 AFM Sunday October 6, I963," 2-3.

58. "Minutes of the Annual Meeting, Local 208 AFM Sunday October 6, I963," 4-5.

59. Demsey Travis, An Autobiography of Black Jazz (Chicago: Urban Research Institute, I983). I29-30.

6o. "Aid Asked For Music Merger," Chicago Daily News, 25 September I963; "Musicians Meeting on Merger," Chicago Daily News, 9 October I963; "New Merger Talks for Negro, White Musicians," Chicago Daily News, 8 October 1963; "Seek Petrillo Merger Help," Chicago Daily News, 24 September I963; all clippings were found in Merger Box \#4, Folder "Chicago Musician 
Union Scrapbook," "Tension Mounts As Local 208's Meeting Nears," Chicago Daily Defender, 23 September 1963, A20; The Reminiscences of Red Saunders, (I978), 87; The Reminiscences of Milton Hinton (I97I), 4-7, in the Oral History Collection of Columbia University; The Reminiscences of Scoville Browne, (I978), 4-6, in the Oral History Collection of Columbia University.

6r. Hunter, "Tension Mounts as Local 208's Meeting Nears."

62. Hunter, "Tension Mounts as Local 208's Meeting Nears."

63. The leaders of Local 208 expressed these views in the meetings with Local ro but they also repeatedly explained their position to the Chicago Defender's Bob Hunter. For an example see: Hunter, "Tension Mounts as Local 208's Meetings Near,." I.

64. "Southside Musicians Prexy For Integration," Chicago Defender, March 30, I963, I; "'Wail Together, Cats,' AFM Tells Chi Unions," Chicago Defender, March 7, I964, I; "Sepia Musicians' Unit Agrees to Aid Merger," Chicago Defender, April 27, 1964, 17..

65. As the leaders of Local 208 and Local ro went into closed meetings with the representative of the International, the Chicago Musicians for Harmonious Integration James Mack began to send letters and telegrams to the meetings, which were read into the record. He argued that there were 200 "dual members" of Local 208 and Local ro whose best interests were not represented by the leadership of either He proposed that three representatives of the "dual members" be allowed to attend the meetings but not have a vote. The leaders of Local Io supported this, most likely because they imagined that the dissident representatives would support their position. Ultimately, the International representative rejected this proposal because the Musicians for Harmonious Integration were not elected officials and therefore lacked a mandate from a majority of the membership. This position was in contradiction to the International's argument that they were forcing the integration of the two locals because of the 200 joining Local Io. "Minutes from meeting October I0, I963," 3-4, Merger Box \#2, Folder "Merger Transcripts," AFM.

66. "Minutes from the October I 5 I 963 meeting," Merger Box \#2, Folder "Merger Transcripts," AFM.

67. "Minutes from the October I 5, I963 meeting" Merger Box \#2, Folder "Merger Transcripts," AFM.

68. "Minutes from the merger meeting January 29, I964," 3, Merger Box \#2, Folder "Merger Transcripts," AFM.

69. "Minutes from the merger meeting January 29, I 964," 5-6, Merger Box \#2, Folder "Merger Transcripts," AFM.

70. Davis, the representative from the Federation, asked Local Io and Local 208 to decide if "it is practical or feasible to elect on a geographical basis I think we should thoroughly discuss before we say a firm 'unacceptable' to this." Miss Motherway, from the Local Io, replied, "How do you go about constructing 
this geographically, since this is a situation that is based on where one lives." In Chicago, where one lives, as the white leaders knew, was related to one's race. "Minutes from the meeting January 29, I964," Io, Merger Box \#2, Folder "Merger Transcripts," AFM. Davis explained election based on former membership in a local, saying, "We cannot predicate an election to office on race, creed, religion, Former affiliation again is a problem because when it is analyzed in the true sense it means predominately one race as against predominately another race and so being highly technical, this again goes back to origin of nationality. ..." King, of Local 208, replied, "Is there any reason for us to be here? You say that the mere fact that we are Local 208 this definitely means that we are Negro. What we are asking for is the right to protect former members of Local 208 who become members of Local Iо." "Minutes from the meeting January 29, I964," I 5, Merger Box \#2, Folder "Merger Transcripts," AFM.

7I. "Minutes from the merger meeting January 29, I964," I2-Merger Box \#2, Folder "Merger Transcripts," AFM.

72. "Minutes from the merger meeting January 29 I964," I8, Merger Box \#2, Folder "Merger Transcripts," AFM.

73. "Minutes from the merger meeting March 23, I964," 8, Merger Box, \#2, Folder "Merger Transcripts," AFM.

74. "Musicians Union Names Two To Push Merger of Locals," Chicago Defender, June 22, I963; "Special Resolution August I5, I965," Merger Box \#I, Folder "Resolution 8/I 5/65 From Local 208 to Local Io," AFM.

75. Halker, "A History of Local 208," 2 I 9.

76. "Special Resolution August I 5 I965," Merger Box \# I, Folder "Resolution 8/I 5/65 From Local 208 to Local Io,"AFM.

77. See the interview with Ken Sweet in Walton, Bronzeville Conversations, 20.

78. "Special Resolution August I5 I965," Merger Box \# I, Folder "Resolution 8/I 5/65 From Local 208 to Local Io,"AFM.

79. "Local Io President Charges AFM Perpetrates Segregation," DownBeat, May I964, 9-Io.

80. Morry Roth, "Negro Local 208 Won't Integrate," Variety, July 3 I, I963, 95, from Merger Box \#4, Folder "Chicago Musicians Union Scrapbook," AFM.

8I. Diamond, Mean Streets, 288.

82. For more on how Chicago's Black institutions provided the blueprints for later Black-led political movements, see Davarian Baldwin, Chicago's New Negroes: Modernity, The Great Migration and Black Urban Life (Chapel Hill: University of North Carolina Press, 2007), 24I-42.

83. Walton, Bronzeville Conversations, $3 \mathrm{I}$.

84. "Facts and Figures from the K.F.A." [no date], Miscellaneous Programs, Pamphlets, relating to Red Saunders, Folder I, Chicago History Museum, Chicago. 
85. Dave Potter, "WBBM Hires 3 Negro Musicians Next Week," Chicago Defender, October 7, I964; Bob Hunter, "First Negro Record Spinner Hired By WCFL," Chicago Defender, August I2, I963.

86. See the interview with Ken Sweet in Walton, Bronzeville Conversations, 20.

87. Robert Lewis, "Negro Musicians Here Charge Discrimination," Chicago Daily News, March 27, 1967, from Merger Box \#4, folder "Chicago Musicians Union Scrapbook," AFM. The lack of jobs for Black musicians following the merger of separate locals was not unique to Black musicians to Chicago. Buffalo reported a similar situation after the merging of the city's local in I969. Like in Chicago, there had been no guarantee of job equity written into the merger. The white musicians continued to get the best jobs, the best pay, and to hold office in the local. "You could complain and you could complain," an African American musician in Buffalo recalled, "but of course the people you were complaining to were the ones who were organizing this kind of strategy, and so basically it fell upon deaf ears." Richard McRae, "Paying their Dues: Buffalo's African American Musicians Union, Local 533, A.F.M., I9I7-I969," Afro-Americans in New York Life and History 20 (January I996): 79.

88. "CSO's Diversity Program is Ready for Next Player," Chicago Tribune, August 2 I, 2005. The Chicago Symphony Orchestra was segregated for I I I years. The organization was quite late in hiring an African American. The New York Philharmonic had Black members off and on since I896 Los Angeles and Minneapolis have had Black members since the I920s. The Denver Symphony has had Black members since I946. Marilyn Marshall, "What's Behind the Shortage of Blacks in Symphony Orchestras?" Ebony, September I 985, 36-39. Professor James Williams, from Columbia College in Chicago, argues that the lack of Black musicians in orchestras and the audience have led his students to "write off any possibility of acceptance in this perceived white American." They feel their only potential for artistic expression is jazz, rap, gospel or pop." "CSP Should Play More Music by Blacks," Chicago Sun-Times, November 25, I993. All sources are from the Vertical File "Orchestras and Minorities," Center for Black Music Research, Columbia College, Chicago,

89. Tom Crown to Amy Absher, September 22, 2012.

90. Travis, An Autobiography of Black Jazz, I91.

9I. Tom Crown to Amy Absher, March 23, 2007.

92. "Meeting of Joint Advisory Committee of Locals Io And 208 implementation order of International Executive Board Concerning Plan of Merger," from Merger Box \#3, Folder "Joint Advisory Committee," AFM; The Reminiscence of Red Saunders, 95-97; Jonathan Zvi Sard Pollack, "Race, Recordings, and Rock ' $\mathrm{n}$ ' Roll: The American Federation of Musicians and the Popular 
Music Challenge, I940-I970" (PhD diss., University of Wisconsin-Madison, I999), I90.

93. George Lewis, A Power Stronger Than Itself: The AACM and American Experimental Music (Chicago: University of Chicago Press, 2008), I63.

94. Lewis, A Power Stronger Than Itself, 87, I6.

95. Buddy Guy and David Ritz, When I Left Home: My Story (Boston: Da Capo Press, 20121, 22 I, 246.

96. Guy, When I Left Home, $22 \mathrm{I}$.

97. "Political Prayer Blues," as cited in Guido van Rijn, The Truman and Eisenhower Blues: African-American Blues and Gospel Songs, I945-I960 (New York: Continuum, 2004), I46.

98. Derrick, "The Move For An Integrated Musicians Union."

99. Hunter, "CMHI Musicians Blast Local 208 Officials."

Ioo. See the interview with Sam Denov in Walton, Bronzeville Conversations, 33 .

Ior. Alyn Shipton, A New History of Jazz (London: Continuum, 200I), $805-7$.

I02. Lewis, A Power Stronger Than Itself, i I6.

I03. Lewis, A Power Stronger Than Itself, Io6.

I04. "Meeting of Joint Advisory Committee of Locals ro and 208 implementation order of International Executive Board Concerning Plan of Merger," from Merger Box \#3, Folder "Joint Advisory Committee," AFM. The Black musicians in Buffalo also suffered the loss of their union building following the merger of the city's locals in McRae, "Paying their Dues," 78-79.

I05. Malcolm, The Musicians Building.

I06. See the interview with Lefty Bates in Walton, Bronzeville Conversations, 32.

I07. Walton, Bronzeville Conversations, 34 .

I08. See the interview with Hillard Brown in Walton, Bronzeville Conversations, 32 .

I09. Tom Crown to Amy Absher, September 22, 2012.

I Iо. See the interview with Morris Ellis in Black, Bridges of Memory, I889 I.

CODA

I. See chapters I and 2.

2. Bibliographical Dictionary of Afro-American Music, s.v. "Dyett, Walter Henri"; Grove Dictionary of Jazz, s.v. "Abrams, Muhal Richard."

3. Doris Evans McGinty, ed., A Documentary History of the National Association of Negro Musicians (Chicago: Center of the Black Music Re- 
search, Columbia College, 2004), 237; Lewis, A Power Stronger Than Itself, Io6.

4. "CSO's Diversity Program is Ready for Next Player," Chicago Tribune, August 2I, 2005; "Orchestras' Overtures to Minorities," Philadelphia Inquirer, April 29, I99 I; "What's Behind the Shortage of Blacks in Symphony Orchestras?" Ebony, September I985, 36-42. All citations from the Vertical File "Orchestras and Minorities," Center for Black Music Research, Columbia College, Chicago. 


\section{Bibliography}

\section{PRIMARY SOURCES}

\section{Archival Collections}

The American Federation of Musicians Local Io-208 Collection. Harold Washington Library, Chicago.

Broadsides Collection. Chicago History Museum, Chicago.

Burgess, Ernest Watson. Papers. Special Collections, Regenstein Library, University of Chicago.

Congress of Racial Equality Papers. Chicago History Museum, Chicago.

Clarke, Sue Cassidy. Collection. Center for Black Music Research, Columbia College, Chicago.

Manuscript Collection. Center for Black Music Research, Columbia College, Chicago.

Map Library. Regenstein Library, University of Chicago, Chicago.

Miller, Paul Eduard. Collection. Center for Black Music Research, Columbia College, Chicago.

NANM. Papers. Center for Black Music Research, Columbia College, Chicago.

Rare Book Collection. Center for Black Music Research, Columbia College, Chicago.

Rare Book Collection. Special Collections, Regenstein Library, University of Chicago.

Saunders Red. Papers, Chicago History Museum, Chicago.

Student Non-Violent Coordinating Committee Papers. Chicago History Museum, Chicago.

Theodore Stone. Collection. Center for Black Music Research, Columbia College, Chicago.

Vertical Files. Center for Black Music Research, Columbia College, Chicago. 
Walker-Hill, Helen. Collection. Center for Black Music Research, Columbia College, Chicago.

Walton, Charles. Papers. Vivian G. Harsh Research Collection. Carter G. Woodson Library, Chicago.

Books

Armstrong, Louis. Louis Armstrong, in His Own Words: Selected Writings.

Edited by Thomas Bender. New York: Oxford University Press, I999.

Bechet, Sidney. Treat it Gentle: An Autobiography. Boston: Da Capo Press, 2002.

Berry, Chuck. Chuck Berry: The Autobiography. New York: Harmony Books, I987.

Bowin, Louis De Koven. The Public Dance Halls of Chicago. Chicago: The Juvenile Protective Association of Chicago, I9I7.

Chicago Commission on Race Relations. The Negro in Chicago: a Study of Race Relations and a Race Riot. Chicago: University of Chicago Press, I922.

Condon, Eddie. We Called it Music: A Generation of Jazz. Boston: Da Capo Press, I998.

Duff, P. J. Side Lights on Darkest Chicago. No place, I 898.

Ellington, Edward Kennedy. Music is My Mistress. New York: Doubleday, I968.

Gart, Galen. First Pressings: The History of Rhythm and Blues. Milford, NH: Big Nickel Publications, I986.

Gillespie, Dizzy. To Be or Not . . to Bop: Memoirs. Edited by Al Frazier. New York: Doubleday, I979.

Guy, Buddy and David Ritz. When I Left Home: My Story. Boston: Da Capo Press. 20I2.

Hughes, Langston. The Langston Hughes Reader. New York: George Braziller, I958.

McGinty, Doris Evans, ed. A Documentary History of the National Association of Negro Musicians. Chicago: Center of the Black Music Research, Columbia College. 2004.

Messrow, Mezz. Really the Blues. New York: Anchor Books, I972.

Perkins, Carl. Go, Cat, Go: The Life and Times of Carl Perkins, the King of Rockabilly. New York: Hyperion, I996.

Samuels, William Everett, and Donald Spivey. The Union and the Black Musician: The Narrative of William Everett Samuels and Chicago Local 208. Lanham, MD: University Press of America, I984.

Vice Commission of Chicago, the. The Social Evil in Chicago. Chicago: Gunthorp-Warren Printing Company, I9 I I.

Walton, Charles. Bronzeville Conversations: The Tempo of the Times the 
Struggle for an Integrated Musicians Union. Chicago: Charles Walton, I993.

Wells-Barnett, Ida B. Crusade for Justice: The Autobiography of Ida B. WellsBarnett. Chicago: University of Chicago Press, I970.

Work, John W., et al. Lost Delta Found: Rediscovering the Fisk UniversityLibrary of Congress Coahoma County Study, I94I-I942. Edited by Robert Gordon and Bruce Nemerov. Nashville: Vanderbilt University Press, 2005.

Wright, Richard. American Hunger. New York: Harper, I983.

Wright, Richard. I 2 Million Voices. New York: Thunders' Mouth Press, I 988.

Films and Video Recordings

Bland, Edward O., dir. The Cry of Jazz. Video recording. Unheard Music Series, I959.

Malcolm, Dino, dir. The Musicians Building. Video recording. Nine Morning Productions, I988. Film Collection, Center for Black Music Research, Colombia College, Chicago.

Government Documents and Publications

Berry v. United States, 295 F.2d I92, I93-I94 (8th Cir. I96I), cert, denied, 368 U.S. 934 (I96I).

U.S. Congress House. Hearings before the Select Subcommittee on Legislative Oversight of the Committee on Interstate and Foreign Commerce. I960. Deceptive Practices in Radio and Television. House of Representatives, 86th Congress, 2nd Session.

U.S. Congress House. Hearings before a subcommittee of the Committee on Interstate and Foreign Commerce. Responsibilities of Broadcasting Licensees and Station Personnel. 86 Congress. 2nd Session.

Newspapers and Magazines

American Mercury

Ave Maria

Billboard Magazine

California Eagle

Cash Box

Catholic Choirmaster

Chicago Daily News

Chicago Defender

Chicago Sun-Times

Chicago Tribune

Citizens' Council

Down Beat 


\section{Ebony}

Houston Informer and Texas Freedman

Jet

Liguorian

Living Blues Magazine

Los Angeles Times

Negro Digest

New York Times

Newsweek Magazine

Our World

Pittsburgh Courier

Rolling Stone

Sponsor

Tan

Time Magazine

Variety

WaxPoetics

White Sentinel

\section{Oral Histories}

The Reminiscences of Scoville Browne. The Oral History Collection of Columbia University, I978.

The Reminiscences of Roy Eldridge. The Oral History Collection of the Jazz Institute, Rutgers University, I982-I983.

The Reminiscences of Charles Elgar. The Oral History Collection of the Hogan Jazz Archive, Tulane University, 1978.

The Reminiscences of Milton Hinton. The Oral History Collection of Columbia University, I97 I.

The Reminiscences of Red Saunders. The Oral History Collection of the Jazz Institute, Rutgers University, I978.

Theses, Dissertations, and Unpublished Papers

Becker, Howard Saul. "The Professional Dance Musician in Chicago." Master's thesis, University of Chicago, I949.

Flandreau, Suzanne. "Classical Music in the Chicago Renaissance." Unpublished paper, copy in author's possession, n.d.

Patterson, Charles Willis. "A History of the National Association of Negro Musicians: The First Quarter Century I9I9-I943." PhD diss., Wayne State University, I 993.

Pollack, Jonathan Zvi Sard. "Race, Recordings, and Rock ' $\mathrm{n}$ ' Roll: The American Federation of Musicians and the Popular Music Challenge, I940I970." PhD diss., University of Wisconsin-Madison, I999. 
Spaulding, Norman. "History of Black Oriented Radio in Chicago I929I963." PhD diss., University of Illinois at Urbana Champaign, I98 I.

Webb, John. "Whispers of Love." Unpublished manuscript, Center for Black Music Research, Columbia College, Chicago, Illinois, n.d.

\section{SECONDARY SOURCES}

Books

Abdul, Raoul. Blacks in Classical Music: A Personal History. New York: Dodd, Mead \& Company, I977.

Altschuler, Glenn C. All Shook Up: How Rock 'n' Roll Changed America. New York: Oxford University Press, 2003.

Anderson, Jervis. This Was Harlem: A Cultural Portrait, I900-I950. New York: Farrar, Straus and Giroux, I982.

Aparicio, Frances. Listening to Salsa: Gender, Latin Popular Music, and Puerto Rican Culture. Hanover, NH: University Press of New England, I998.

Bachin, Robin. Building the South Side: Urban Space and Civic Culture in Chicago I890-I919. Chicago: University of Chicago Press, 2004.

Baldwin, Davarian. Chicago's New Negro: Modernity, The Great Migration, and Black Urban Life. Chapel Hill: University of North Carolina Press, 2007.

Barlow, William. "Looking Up At Down": The Emergence of Blues Culture. Philadelphia: Temple University Press, I989.

Barlow, William. Voice the Making of Black Radio. Philadelphia: Temple University Press, I999.

Bertrand, Michael T. Race, Rock, and Elvis. Chicago: University of Illinois Press, 2000.

Best, Wallace. Passionately Human, No Less Divine: Religion and Culture in Black Chicago I9I5-I952. Princeton, NJ: Princeton University Press, 2005 .

Black, Timuel. Bridges of Memory: Chicago's First Wave of Black Migration Evanston, IL: Northwestern University Press, 2003.

Black, Timuel. Bridges of Memory Volume 2: Chicago's Second Generation of Black Migration. Evanston, IL: Northwestern University Press, 2008.

Black Public Sphere Collective, the. The Black Public Sphere: A Public Culture Book. Chicago: University of Chicago Press, I995.

Brindas, Kenneth. Swing: The Modern Sound. Jackson: University Press of Mississippi, 200 I.

Burke, Patrick. "Come in and Hear the Truth": Jazz and Race on $52^{\text {nd }}$ Street. Chicago: University of Chicago Press, 2008. 
Cantor, Milton. Black Labor in America. New York: Negro Universities Press, I969.

Clark, Kenneth Bancroft. Dark Ghetto: Dilemmas of Social Power. New York: Harper \& Row, I965.

Cobb, James C. The Most Southern Place on Earth: The Mississippi Delta and the Regional Identity. New York: Oxford University Press, I992.

Cohen, Lizabeth. Making A New Deal: Industrial Workers in Chicago, I9I9I939. Cambridge: Cambridge University Press, I990.

Cohen, Rich. The Record Men: The Chess Brothers and the Birth of Rock and Roll. New York: W. W. Norton, 2004.

Cohodas, Nadine. Queen: The Life and Music of Dinah Washington. New York: Pantheon, 2004.

Cohodas, Nadine. Spinning Blues into Gold: The Chess Brothers and the Legendary Chess Records. New York: St. Martin's, 2000.

Dempsey, Travis. An Autobiography of Black Jazz. Chicago: Urban Research Institute, I983.

Dennison, Sam. Scandalize My Name: Black Imagery in American Popular Music. New York: Garland Publishing, I982.

DeVeaux, Scott. The Birth of Bebop: A Social and Musical History. Berkeley and Los Angeles: University of California Press, I 997.

DeWitt, A. Chuck Berry: Rock 'n' Roll Music. Ann Arbor, MI: Pierian Press, I985.

Diamond, Andrew J. Mean Streets: Chicago Youths and the Everyday Struggle For Empowerment in the Multiracial City, I908-1969. Berkeley and Los Angeles: University of California Press, 2009.

Drake, St. Clair, and Horace R. Clayton. Black Metropolis: A Study of Negro Life in a Northern City. Chicago: University of Chicago Press, I945, I 993.

Duncan, Otis Dudley, and Beverly Duncan. The Negro Population of Chicago: A Study of Residential Succession. Chicago: University of Chicago Press, I975.

Epstein, Daniel Mark. Nat King Cole. New York: Farrar, Straus and Giroux, I999.

Erenberg, Lewis. Swingin' the Dream: Big Band Jazz and the Rebirth of American Culture. Chicago: University of Chicago Press, I998.

Floyd, Samuel A. The Power of Black Music: Interpreting Its History From Africa to the United States. New York: Oxford University Press, I 995.

Gerstle, Gary. American Crucible: Race and Nation IN the Twentieth Century. Princeton, NJ: Princeton University Press, $200 \mathrm{I}$.

Gilmore, Glenda Elizabeth. Gender and Jim Crow: Women and the Politics of White Supremacy in North Carolina, I896-I920. Chapel Hill: University of North Carolina Press, I996.

Goldrosen, John, and John Beecher. Remembering Buddy: the Definitive Biography. New York: Penguin, I986. 
Goran, Paul, and Beth Goran. Woman with Guitar: Memphis Minnie's Blues. Boston: Da Capo Press, I 992.

Gordon, Robert. Can't Be Satisfied: The Life and Times of Muddy Waters. Boston: Little, Brown, 2002.

Goodwin, Carole. The Oak Park Strategy: Community Control of Racial Change. Chicago: University of Chicago Press, I979.

Grazian, David. Blue Chicago: the Search for Authenticity in Urban Blues Clubs. Chicago: University of Chicago Press, 2003.

Gregory, James. The Southern Diaspora: How the Great Migrations of Black and White Southerners Transformed America. Chapel Hill: University of North Carolina Press, 2005

Griffin, Jasmine Farah. Who Set you Flowin': The African American Migration Narrative. New York: Oxford University Press. I995.

Grossman, James R. Land of Hope: Chicago, Black Southerners, and The Great Migration. Chicago: University of Chicago Press, I989.

Guralnick, Peter. Dream Boogie: The Triumph of Sam Cooke. New York: Little, Brown, 2005.

Guglielmo, Thomas A. White On Arrival: Italians, Race, Color, and Power in Chicago, I890-1945. New York: Oxford University Press, 2003.

Higginbotham, Evelyn Brooks. Righteous Discontent: The Women's Movement in the Black Baptist Church, I880-1920. Cambridge, MA: Harvard University Press, I993.

Hirsch, Arnold R. Making the Second Ghetto: Race and Housing in Chicago, I940-I960. New York: Cambridge University Press, I983.

Hyra, Derek S. The New Urban Renewal: The Economic Transformation of Harlem and Bronzeville. Chicago: University of Chicago Press, 2008.

Kenney, William Howland. Chicago Jazz: A Cultural History, I904-I930. New York: Oxford University Press, I993.

Lamar, Howard Roberts. The Far Southwest: I846-I9I2. New Haven, CT: Yale University Press, I966.

Langum, David J. Crossing Over the Line: Legislating Morality and the Mann Act. Chicago: University of Chicago Press, I994.

Leidenberger, Georg. Chicago's Progressive Alliance: Labor and the Bid for Public Streetcars. DeKalb: Northern Illinois University Press, 2006.

Leiter, Robert D. The Musicians and Petrillo. New York: Bookman Associates, Inc., I953.

Leonard, Neil. Jazz and the White Americans: The Acceptance of a New Art Form. Chicago: University of Chicago Press, I962.

Lewis, George E. A Power Stronger Than Itself: The AACM and American Experimental Music. Chicago: University of Chicago Press, 2008.

Lipsitz, George. Time Passages: Collective Memory and American Popular Culture. Minneapolis: University of Minnesota Press, I990. 
Malone, Bill C., and David Stricklin. Southern Music/American Music. Lexington: University Press of Kentucky, 2003.

Marable, Manning. Race, Reform, and Rebellion: The Second Reconstruction in Black America, I945-I990. Jackson: University Press of Mississippi, I99I.

Martin, Linda, and Kerry Segrave. Anti-Rock: The Opposition to Rock ' $n$ ' Roll. North Haven, CT: Shoe String Press, I 988.

McKee, Margaret, and Fred Chisenhall. Beale, Black and Blue: Life and Music of Black America's Main Street. Baton Rouge: Louisiana State University Press, I993.

Melnick, Jeffery Paul. A Right to Sing the Blues: African Americans, Jews, and American Song. Cambridge, MA: Harvard University Press, I999.

Millard, Andre. America on Record: A History of Recorded Sound. New York: Cambridge University Press, I995.

Nuzum, Eric. Parental Advisory: Music Censorship in America. New York: Perennial, 200I.

Ogren, Kathy J. The Jazz Revolution: Twenties America and the Meaning of Jazz. New York: Oxford University Press, I989.

Oliver, Paul. Blues Fell This Morning: Meaning in the Blues. Cambridge: Cambridge University Press, I960.

Oliver, Paul. Conversations with the Blues. Cambridge: Cambridge University Press, I 997.

Pastras, Phil. Dead Man Blues: Jelly Roll Morton Way Out West. Berkeley and Los Angeles: University of California Press, $200 \mathrm{I}$.

Payne, Charles M. I've Got the Light of Freedom: The Organizing Tradition and the Mississippi Freedom Struggle. Berkeley and Los Angeles: University of California Press, I995.

Polinkoff, Alexander. Waiting for Gautreaux: A Story of Segregation, Housing, and the Black Ghetto. Evanston, IL: Northwestern University Press, 2006.

Porter, Eric Porter. What is this Thing Called Jazz? African American Musicians as Artists, Critics, and Activists. Berkeley and Los Angeles: University of California Press, 2002.

Putman, John C. Class and Gender Politics in Progressive-Era Seattle. Reno: University of Nevada Press, 2008.

Ramsey, Guthrie. Race Music: Black Cultures from Bebop to Hip-hop. Berkeley and Los Angeles: University of California Press, 2003.

Reckless, Walter Cade. Vice in Chicago. Chicago: University of Chicago Press, I993.

Reed, Christopher Robert. The Rise of Chicago's Black Metropolis, I920I929. Urbana: University of Illinois Press, 20 I I. 
Robert, John Storm. Latin Jazz: The First of the Fusions, I88os to Today. New York: Schirmer Books, I999.

Rowe, Mike. Chicago Blues: The City and the Music. London: DaCapo, I973. Ruppli, Michel. The King Labels: A Discography, volume I. Westport, CT: Greenwood Press, I985.

Sanjek, Russell. Pennies From Heaven: The American Popular Music Business in the Twentieth Century. Boston: Da Capo Press, I996.

Segrest, James, and Alex Rosen. Moanin' at Midnight: The Life and Times of Howlin' Wolf. New York: Pantheon, 2004.

Self, Robert O. American Babylon: Race and the Struggle For Postwar Oakland. Princeton, NJ: Princeton University Press, 2003.

Sengstock, Charles A. That Toddlin' Town: Chicago's White Dance Bands and Orchestras, I900-I950. Urbana: University of Illinois Press, 2004.

Shipton, Alyn. A New History of Jazz. London: Continuum, 200 I.

Sitkoff, Harvard. A New Deal For Blacks The Emergence of Civil Rights as a National Issue: The Depression Decade. New York: Oxford University Press, I978.

Small, Christopher. Music of the Common Tongue: Survival and Celebration in Afro-American Music. London: John Calder, 1987.

Small, Christopher. Musicking: The Meaning of Performing and Listening. Hanover, NH: University Press of New England, I998.

Spear, Allan H. Black Chicago: The Making of a Negro Ghetto, I890-I920. Chicago: University of Chicago Press, I967.

Sugrue, Thomas J. Origins of the Urban Crisis: Race and Inequality in Postwar Detroit. Princeton, NJ: Princeton University Press, I996.

Sugrue, Thomas J. Sweet Land of Liberty: The Forgotten Struggle for Civil Rights in the North. New York: Random House, 2008.

Szwed, John F. Space is the Place: The Lives and Times of Sun Ra. New York: Pantheon, I997.

Teachout, Terry. Pops: A Life of Louis Armstrong. New York: Houghton Mifflin Harcourt, 2009.

Vaillant, Derek. Sounds of Reform: Progressivism and Music in Chicago, I873-I935. Chapel Hill: University of North Carolina Press, 2003.

Van Rijn, Guido. Roosevelt's Blues: African-American Blues and Gospel Songs on FDR. Jackson: University Press of Mississippi, I997.

Van Rijn, Guido. The Truman and Eisenhower Blues: African-American Blues and Gospel Songs, I945-I960. New York: Continuum, 2004.

Von Eschen, Penny M. Satchmo Blows Up the World: Jazz Ambassadors Play the Cold War. Cambridge, MA: Harvard University Press, 2004.

Wald, Elijah. Escaping the Delta: Robert Johnson and the Invention of Blues. New York: Amistad, 2004. 
Wald, Gayle. Shout Sister Shout! The Untold Story of Rock 'n' Roll Trailblazer Sister Rosetta Tharp. Boston: Beacon Press, 2007.

Walker-Hill, Helen. From Spirituals to Symphonies: African American Women Composers and their Music. Westport, CT: Greenwood Press, 2002.

Ward, Brian. Just My Soul Responding: Rhythm and Blues, Black Consciousness, and Race Relations. Berkeley and Los Angeles: University of California Press, I998.

Woodard, Komozi. A Nation Within A Nation: Amiri Baraka (LeRoi Jones) «) Black Power Politics. Chapel Hill: University of North Carolina Press, I999.

Work, John W., L. W. Jones, and S. C. Adams, Lost Delta Found: Rediscovering the Fisk University-Library of Congress Coahoma County Study, I94II942. Edited by Robert Gordon and Bruce Nemerov. Nashville: Vanderbilt University Press, 2005.

Periodicals

Arnesen, Eric. "Up From Exclusion: Black and White Workers, Race, and the State of Labor History." Reviews in American History 26 (March I998): I 46-74.

Bloch, R.G., N.B. Tucker and J.E. Bryant. "Roentgenologic Group Examinations for Pulmonary Tuberculosis-In Negroes in Chicago: Preliminary Report." Journal of The American Medical Association I I 5 (October I940): I 866-73.

Bone, Robert. "Richard Wright and the Chicago Renaissance." Callallo 28 (Summer I986): 446-68.

Bowers, Jane. "'I can stand mo trouble than any gal my size': Observations on the Meaning of the Blues of Estelle 'Mama' Yancey." American Music I I (Spring I993): 28-53.

Brody, Martin. "'Music for the Masses': Milton Babbitt's Cold War Music Theory." Musical Quarterly 77 (Summer I993): I6I-92.

Collins, Chiquita A., and David R. Williams. "Segregation and Mortality: The Deadly Effects of Racism?" Sociological Forum I4 (September I999): 495523 .

Floyd, Samuel. "An Oral History: The Great Lakes Experience," Black Perspective in Music I I (Spring I983): 4I-6I.

Gellman, Erik S. "'Carthage Must Be Destroyed': Race, City Politics, and the Campaign to Integrate Chicago Transportation Work, I929-I943," Labor: Studies in Working-Class History of the Americas 2 (Spring 2005): 8 I-I I 4. Haaga, J. G. "Jazz Musicians-Live Fast, Die Young Stereotype Not Refuted." American Journal of Public Health 82 (May I992): 76I.

Halker, Clark. "A History of Local 208 and the Struggle for Racial Equality in the American Federation of Musicians." Black Music Research Journal 8 (Fall I988): 2 I 2-22. 
Herer, B. "The Longevity and Causes of Death of Jazz Musicians, I990-I999." Medical Problems of Performing Artists I 5 (September 2000): pp. I I9-I 22.

House, Roger. "Work House Blues: Black Musicians in Chicago and the Labor of Culture During the Jazz Age." Labor: Studies in Working-Class History of the Americas 9 (Winter 2012): IOI-I 8.

Howard, Jan, and Barbara L. Holman. "The Effects of Race and Occupation on Hypertension Mortality." The Milbank Memorial Fund Quarterly 48 (July I970): 263-96.

Kamin, Jonathan. "Parallels in the Social Reactions to Jazz and Rock." Black Perspective in Music 3 (Autumn I975): 278-98.

Kelley, Robin D. G. "'We Are Not What We Seem': Rethinking the Black Working Class in the Jim Crow South." Journal of American History 80 (June I993): 75-I I 2.

"Maxwell Street at Mid-Century." Chicago History 26 (Summer I997): 4453.

McRae, Richard. "Paying their Dues: Buffalo's African American Musicians Union, Local 533, A.F.M., I917-I969." Afro-Americans in New York Life and History 20 (January I996): 77-85.

Narvaez, Peter. "The Influence of Hispanic Music Cultures on AfricanAmerican Blues Musicians." Black Music Research Journal 22 (Supplement: Best of BMRJ, 2002): I75-96.

Potter, Lloyd B. "Socioeconomic Determinants of White and Black Males' Life Expectancy Differentials, I980." Demography 28 (May I99I): 303-2I.

Smith, Susan J. "Beyond Geography's Visible Worlds: A Cultural Politics of Music." Progress in Human Geography 2 I (I 997): 502-29.

Thornton, Hortense. "The Barbershop and Beauty Parlor in Afro-American Literature." Pacific Coast Philology I 4 (October, I979): 76-83.

Tolnay, Stewart E. "The Great Migration and Changes in the Black Family, I940-I990." Social Forces 75 (June I997): I 2 I3-38.

Tolnay, Stewart E., and E. M. Beck. "Racial Violence and Black Migration in the American South, I9ro to I930." American Sociological Review (February I992): IO3-I6.

Vaillant, Derek W. "Sounds of Whiteness: Local Radio, Racial Formation, and Public Culture in Chicago, I92 I-I935." American Quarterly 54 (March 2002): 25-66.

Winick, Charles. "The Use of Drugs by Jazz Musicians." Social Problems 7 (Winter I959-I960): 240-53.

\section{Reference Works}

Carter, Susan B., et al. Historical Statistics of the United States. New York: Cambridge University Press, 2006.

Grossman, James R., et al. The Encyclopedia of Chicago. Chicago: University of Chicago Press, 2004. 
Jeter, James Philip. International Afro Mass Media: A Reference Guide. Westport, CT: Greenwood Press, I996.

Kernfeld, Barry Dean. The New Grove Dictionary of Jazz. London: Macmillan, I988.

Komara, Edward M. Encyclopedia of the Blues. New York: Routledge, 2006.

McNeil, W. K. Encyclopedia of American Gospel Music. New York: Routledge, 2005 .

Sheldon, Harris. Blues Who's Who: A Biographical Dictionary of the Blues Singers. New Rochelle, NY: Arlington House, I979.

Southern, Eileen. Bibliographical Dictionary of Afro-American Music. Westport, CT: Greenwood Press, I982.

Taft, Michael. Blues Lyrics Poetry: An Anthology. New York: Garland Publishing, I983. 


\section{Index}

Abbott, Robert, I 5

Abrams, Muhal Richard, I43

Alexander, Martin "Sparx," I4 I

American Federation of Musicians.

See Chicago, protest; Chicago, segregation, employment; Chicago, segregation, impact on music; Chicago segregation, spatial; Chicago, segregation, venues; Petrillo, James

Anderson, Carol, I I9-2 I

Anderson, Marian, I2O

Arkestra, 79, I65n.I I I

Armstrong, Louis, 25, 3 I, 45, 47, 53, IO3, I 26, I 72 n. I 8

Artistic Heritage Ensemble of Chicago, I4 I

Association for the Advancement of Creative Musicians, 5, 6, I 43-44, I 48

Bates, William "Lefty," I 28, I32, I46 Bechet, Sidney, 46, 47

Benson, Al, 9I, 92, I IO

Berry, Chuck, 73, I I4-I 8

"Bilbo is Dead," 54, 76

Billboard, 88, 90, 94, 95, 96, I03, I04, I05, IIO, II 2

Black and Tans, 3 I, I07

Black Clubwomen, 34, 40, 67

Black Cultural Sphere, 8, I I, I7, 20, 43, $50,63, \mathrm{I} 2 \mathrm{I}, \mathrm{I} 25, \mathrm{I} 44$

Black Literati, 8, 40-4I, 67, 77-79, IOI, I I 7
Black Middle Class, 22, 34-4I, 43, 76, 88, I 22, I 23, I 39, I 44

Black Press, 3, 36, 38, 39, 43, 77, IOI, II $3, \mathrm{I} 2 \mathrm{O}, \mathrm{I} 3 \mathrm{O}, \mathrm{I} 32$

Bland, Edward, 79-8I

Bonds, Margaret, 78-8I

Bowie, Lester, I 43

Braxton, Anthony, I4 4

Bronzeville, I4, I I, 26, 7 I, 84, IO I

Brooks, Gwendolyn, 3

Broonzy, Big Bill, 57, 74, 75

Brown, Oscar Jr., I 44

Burroughs, Margaret, 3

Capone, Al, 23, 34

Cash Box, 93, 105, 106

Censorship, I3, I04-5, I I I

Chess Records, 54, 82, 86, 87-90, I09I3, II 5, II7, I47, I66-67 n. I4

Chicago

brothels, I9, 20, 33, 36, I07

Chicago Conservatory, I, 43, I48

churches, I, 8, 9, II , 34, 35, 38, 39, 40, 4I, 43, 57, 66, 67, 78, 80, 86 corruption, $8,2 \mathrm{I}, 20,22,29,32-35$ as dream/mecca, I I, 49, 48, 73, I4I Englewood, I I, 84

gambling, I9, 3I, 32, 33, 35, 36, 39, I I 5

Great Depression, 82, I4I, I78 n., 20

Great Migration, 8, 9, I I, I 2, I7, 2 I, $34,35,44,48,50,52,63,85,86$, 98, IOO, I 59 n., 32, I 70 n. 2 
Chicago (continued)

housing projects, 40, I4O, I 42

Hyde Park, 9, 26, 36, 37

Jews, 28, 42, 56, 84, 86, 94

and cooperation with musicians,

$54,82,86,87,88,89,90$, I I 3

jukeboxes, 96, 106

levee, 20-23

Maxwell Street, 28, 56, 82, 84-86, 87

pool halls, 32, 77, 79, 80

prohibition, II I I 7, 2I, 34, 36, 47

protest, I3, I4, 4O, 4I, 88, I2I, I24, I28, I30, I3 I, I37, I39, I43

radio, 9, 38, 9I, 92, II 3

riot, $29,37,43$

scabbing, 56-59, 65-66, 72, 83

segregation, employment, 2, 8, 50,

$59,32,36,77-79,8$ I, I 2 I-25,

I 4 I

segregation, impact on music, 44-48, $68,8 \mathrm{I}, 85,87,89,90,92,96$, IOI, I IO, I I 5, I I 8, I40, I 48, I 46

segregation, neighborhoods, 9, I I, I7, $2 \mathrm{I}, 26,29,36,40,50,84, \mathrm{I} 22$, I 25, I 4 I

segregation, schools, 67, 50, I22, I 24, 64, I 44

segregation, spatial, 8, 2I, 40, 50, I 22, I 25, I4 I

segregation, union, 2, 8, 32, 59, 6072, I 2 I, I 22, I 25, I4I, I44

segregation, venue, 2, I7, I9, 3I, 36, $59,64,7 \mathrm{I}-72,8 \mathrm{I}, \mathrm{IO} 7, \mathrm{I} 22, \mathrm{I} 25$

South Side, II, I2, I6, I9, 20, 22, 25 , $30,33-34,36,38,40,42,44-47$, $48,50,55,56,65-68,72-75,77$, 78, 8I, 84, 86, 9I-92, 97, IO2, I 26-27, I4O-4I, I43, I 6 I

stroll, 22-25, 33, 36, 37, 39, 47, 58, 59, 7I, 84, IO2, I 48

Symphony Orchestra, 56, 60, 67, 68, $78,8 \mathrm{I}, \mathrm{I} 4 \mathrm{O}, \mathrm{I} 46, \mathrm{I} 48$

vice, 8 , I3, I7, I9-23, 26, 28-37, 4I, 45,83 , I I 7

Vice Commission, 17, 20-22, 29, 30, $31,32,33$

Urban League, 3, 7, II, 37, 38, 6I, 70, I23, I42

Woodlawn, I I, 26, I 2 I, I28, I33, 234, I 59
World War I, I I, 23, 26, 39, 42, 64, 66 World War II, 26, 49, 55, 6I, 76, 84, I 45

Chicago Defender, The. See Black Press

Chicago Renaissance, 40, 44, 79

Civil Rights, 3, 8, I3-I4, 38, 52, 6I, IOO, II7, I II-22, I 25, I 30, I39, I 43

Clark, Dick, I Io

Club Delisa, I39, I44

Cohran, Philip, I4I, I43

Cole, Nat King, 64, 7 I, 98-Ioo, Io8, II 3, II 4, I I7, I I 8, I 47

Condon, Eddie, 45-47

Congressional Hearings, payola, I09, I IO, I I 2

Cooke, Sam, II4, II7, II 8, I 47

"Creole Queen," 74

Crudup, Arthur, 53-55, 74

"Cry of Jazz," 79-80

Dawson, William, 3

De Priest, Oscar, 3, I 54 n., 47

Delta, Mississippi, 8, 50, 52-55, 87, IOO

Dett, Nathaniel R., 4I-43, 47, 8I, 97, II7, I2I, I46, I 48 , I 55 n. 74

Disc Jockeys, I 2, I3, 83, 90, 91, 92, 93, 94, 95, 96, 97, I00, I02, I07, I08, I09, I IO, I I 2, I4I

Dreamland, 36, 45

Dubois, WEB, 2, 36, 38, 4I, I 23

DuSable High School, 64, 77, I 2 I, I44, I 48, I 70 n., 2

Dyett, Walter, 63-65, 77, I2 I-22, I44, I 47, I 48

Eldridge, Roy, I 58 -I 59 n., 3 I

Elgar, Charles, I 2 I, I 22, I 52 n., 22

Ellington, Duke, 22, 23, 7I, 9I

Ellison, Ralph, 67

Evans, Sam (disc jockey), 93-94

Fisk University, 54, I00

Freed, Alan, 94, 95, I07, I IO, II3, I I4

Gershwin, George, I08

Great Lakes Training Station, 48

Green, Benny, 64

Gilmore, John, 64 
Gray, Harry, I 2 I, I 22, I 32, I 33, I4

Guy, Buddy, I4I, I 66 n., I 4

Hammerstein, Oscar, Io8

Hampton, Fred, I 25

Harlem, 3, 2 I, 38, 44, 79, 87, IO3

Harris, Wynonie, I I 5, I I 8

Hartman, Johnny, 64

Hines, Earl, 47, 53

Hinton, Milton, 46, 47

jobs, 78,79

recording, 88-89

segregation, 65

Holt, Nora, 42-43, I47

House, Son, 52

Hughes, Langston, 28, 29, 78, 79, IOI, I 77

Hunter, Alberta, 3

Interracial relationships,

marriage, I 57 n., 3

in music venues, 23, 30-32, 36, 43, 46,47 , I I 6

Johnson, John, 3

Jones, Dolly, 57, I 58 n., 3 I

Jordan, Joe, I 6

Jordan, Louis, 53, 54, I I4

King, B.B., 48, 88, 89, I 57 n., 3

King, Martin Luther Jr., I I 8

King Oliver' Creole Band, 77

Lenoir, J.B., 73-74

Lynching, I I, 39, 52, 54

Little Richard, I I4, I I 5

Mack, James, I3I-I 32, I4O, I 82 n., 65

Macomba, 98

Malcolm X, I 25

Mann Act, I I 6

March on Washington, 76, I 22

Martin, Roberta, I 59 n., 32

Memphis Minnie, 54, 57, 73, I47, I 58 n., 3 I

Meredith, James, 96

Monroe, Bill, 53, 7 I

Motley, Archibald J. Jr., 3

Muddy Waters, Delta, 49-55 employment -56

house, I I 4, I 47

independent recordings, $87,88,90$, 96

"Make Love To You", 94, 95, 96

Maxwell Street, $84-85$

migration, 49, 82-83

performances, $82,85,95$, I I 3, I I4, I I 8 , I 58 n., 30, I 70 n., 45, I75 n., $6 \mathrm{I}$

Muhammad, Elijah, I 25

Music Business

Apollo Records, IO3-5

ASCAP, 105, I08, I09, I I I

BMI, I05, 108, 109,

Capitol Records, 106

Covers/covering, 53, I I, I I 2

Decca Records, I I 4

King Records, I I 5

Mercury Records, I06

"Negro programming," I I 3

Okeh Records, 47

Paramount Records, 3

Payola, 92, 93, I09-I 2

Race music, 47

disruption of, 87, 94-95, 96, I00IOI

proposed banning of, IOI-IO4

"rhythm without the blues," I I I-I 2

Savoy Records, I03-5

sheet music, I6, 93, 96, I08, I I 2

Sun Records, 82, 89, I03

Top Forty Radio, I I 2, I I 3

Music Education, 42, 44, 63-64, 77, I 2 I, I 2 I, I 3 I, I47-48, I 57 n., 3. See also Dyett, Walter; Chicago Conservatory

NAACP, 36, 39, 98-Ioo

National Association of Negro Musicians, 42, 43, 44, 77, I47, I 48

National Negro Opera Company, 68

New Orleans, 22, 23, 44, 45, 46, 95, IO2, I 2 I, I 22

Oak Park, Illinois, I I9-I 2 I

Pekin Theater, I, I6-22, 36, 39, 40, 43

Perkins, Carl, I I 4

Petrillo, James 
I93 I merger talks, 6I-62

I 948 ban, 87

amalgamated unions, 62, I 47

Grant Park, I47

rumors, 65

as union president, 63-65, I 24, I 28, I33, I 35

use of force, 62

West Side, 62

Phillips, Sam, 89

Preves, Milton, I I 8-I 20

Price, Florence, 42, 43, 67

Poro's Beauty College, 67

Porter, Cole, Io8

Pullman Porters, I, 3

Rainey, Ma, 3

Randolph, Philip A., 76, I23, I 24

Richards, Bernard, I 35

Rogers, Jimmy, 57

Savoy Ballroom, 23, 86,

Saunders, Red, I25-I26, I3O, I 3 I, I 35 , I 37, I 38, I 46

bandleader, I 27, I 32

economic, 38-39, I 23, I 25

institution building, I3-I4, 44, 59$6 \mathrm{I}, 63-65,78, \mathrm{I} 23$

integration, I23-I25, I 34, I36-39, I $44-45$, I 46

Kole Facts Association, I 39

leaders of Local, 208, I 23-I 24

passing, I 26

problems with union, I 79 n., 35

protest leadership, I 2 I-I 22, I 27-29, I 32 , I 80 n., 44

resisting segregation, $17,39,66,67$

self-sufficiency, 2, 8, I4, 7I, I 23

Sears and Roebuck Co., I, 48, 52, 53, $83,86,95$
Sinatra, Frank, I08

"social myth," 26, 30-32, 34, 4I, 47

Still, Grant, 67

Storyville, 45

Tampa Red, 57, 6I

Tharp, Rosetta, 57-58, I 59 n., 32

Turner, Ike, 89

Vaughan, Sarah, 7I, 9 I

Variety, 92, 93, IO2-I I

Walton, Charles, I3 I, I32, I46

Washington, Booker T., 2, 38-39, I 2223

Washington, Dinah, 64, 7I

Washington, Leon, I35, I 37

White, Clarence Cameron, 42

Williams, Camilla, 67

Williams, Mayo, 3

Wolf, Howlin', 82-83, 89, 90, 95, I47

Wright, Richard, 3, 40-4I

Yancey, Estella, 58

Yancey, Jimmy, 58

Youth

Black youth, 77, I24, I 26, I 43

domino theory of music, IO2, I7 I n., I 83

integrated shows, 94-95, 96-97, IOI, I I 5 , I I 6

market, I I 3

protection of white youth, IOI-3, IO9 rock and roll riots, I07, I I 5

street gangs, 28, 29, I 24, I 52 n., 22

white youth's shift in tastes, I 2, 83, 94-95, 96, IOO-IOI, IIO-II, II7, I I 8 , I 69 n. 42

Zanzibar, 7I, 82, 85, 86 